NYELVTUDOMÁNYI ÉRTEKEZÉSEK

165. sz.

\title{
A MAI MAGYAR NEOLOGIZMUSOK SZEMANTIKÁJA
}

ÍRTA

SÓLYOM RÉKA

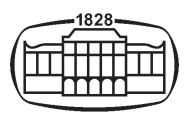

AKADÉMIAI KIADÓ, BUDAPEST 


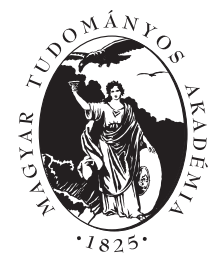

A kiadvány megjelenését a Magyar Tudományos Akadémia és az OTKA a K81315 azonosító számú kutatás keretében támogatta.

\author{
Lektorálta \\ BENCZES RÉKA, PETHÖ JÓZSEF \\ Sorozatszerkesztö \\ KOROMPAY KLÁRA
}

ISBN 9789630595483

Kiadja az Akadémiai Kiadó, az 1795-ben alapított Magyar Könyvkiadók és Könyvterjesztők Egyesülésének tagja 1117 Budapest, Prielle Kornélia u. 21-35. www.akademiaikiado.hu

Első magyar nyelvü kiadás: 2014

(C) Sólyom Réka, 2014

A kiadásért felelős az Akadémiai Kiadó Zrt. igazgatója

Felelős szerkesztő: Pomázi Gyöngyi

Termékmenedzser: Egri Róbert

Szerkesztette: Földes Zsuzsanna

Nyomdai előkészítés: Mocsonoky Gábor

A nyomdai munkálatokat a Prime Rate Kft. végezte

Felelős vezetö: Tomcsányi Péter

Budapest, 2014

Kiadványszám: TK120073

Megjelent 11,26 (A/5) ív terjedelemben

HU ISSN 0078-2866

Minden jog fenntartva, beleértve a sokszorosítás,

a nyilvános előadás, a rádió- és televízióadás, valamint a fordítás jogát, az egyes fejezeteket illetően is.

Printed in Hungary 


\section{TARTALOM}

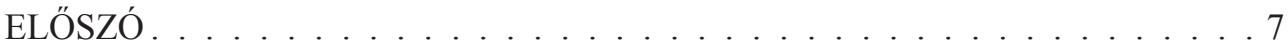

1. BEVEZETÉS: A KUTATÁS TÁRGYA, CÉLJA, INDOKOLTSÁGA, FELÉPÍTÉSE, MÓDSZERTANA ÉS ALAPFOGALMAI . . . . . . . . . . . . . 9

1.1. A kutatás tárgya és célja . . . . . . . . . . . . . . . . . . . 9

1.2. A vizsgált téma jelentősége, újszerüsége, a vizsgálat indokoltsága . . . . . . 10

1.3. Elméleti háttér . . . . . . . . . . . . . . . . . . . . . . 10

1.3.1. A funkcionális nyelvészet . . . . . . . . . . . . . . . 11

1.3.2. A kognitív szemantika . . . . . . . . . . . . . . . . . . . 11

2. TÉMAFELVETÉS; A NEOLOGIZMUS TÖBB SZEMPONTÚ

DEFINIÁLÁSÁNAK SZÜKSÉGESSÉGE. . . . . . . . . . . . . . . . . . 13

2.1. Fogalomtörténeti áttekintés: a neologizmus fogalmának értelmezése

a korábbi szakirodalomban. . . . . . . . . . . . . . . . . . 13

2.1.1. Ókor . . . . . . . . . . . . . . . . . . . . 13

2.1.2. A neologizmus fogalmának változása a felvilágosodás előtt és alatt . . 14

2.1.3. A neologizmusok tárgyalása a vonatkozó magyar szakirodalomban 18-19. század . . . . . . . . . . . . . . . . . . 15

2.1.4. Definíciók, felosztások a 20-21. századi magyar és külföldi szakirodalomban . . . . . . . . . . . . . . . 16

2.2. A neologizmusdefiníciókból fakadó ellentmondások, hiányosságok . . . . . 17

2.3. Kísérlet a neologizmus több szempontú definiálására . . . . . . . . . . . . 19

2.4. A nyelvi változás dimenziójának bevonása a neologizmusok vizsgálatába . . 20

2.5. A kognitív nyelvészeti megközelítésböl fakadó lehetőségek . . . . . . . . . 21

2.5.1. Konceptualizáció . . . . . . . . . . . . . . . . . . 21

2.5.2. Kategorizáció . . . . . . . . . . . . . . . . . 21

2.5.3. Elötér-háttér. . . . . . . . . . . . . . . . . . 22

2.5.4. Konvencionalizáltság és kreativitás . . . . . . . . . . . . . 23

2.5.5. Célstruktúra és jóváhagyó struktúra. . . . . . . . . . . . . . . . 24

2.5.6. Összetett sémák működése a fogalmi konstruálás folyamatában . . . . 24

2.6. A szleng jelenségének viszonya a neologizmusokhoz . . . . . . . . . . . 25

2.7. A közlő és a befogadó stílustulajdonítása . . . . . . . . . . . . . . 26 


\section{ELMÉLETI ÁTTEKINTÉS: A VIZSGÁLANDÓ SZEMANTIKAI}

SZERKEZETEK . . . . . . . . . . . . . . . . . . . 27

3.1. A metonímia . . . . . . . . . . . . . . . . . . . . . . . . 27

3.1.1. A metonímia az ókorban és a középkorban: a retorikai hagyomány . . 27

3.1.2. Metonímiaértelmezések a reneszánsztól a felvilágosodásig . . . . . . 28

3.1.3. A metonímia értelmezései a 19. századtól kezdve Lakoff-Johnson megközelítéséig . . . . . . . . . . . . . . . 28

3.1.4. A metonímia kognitív nyelvészeti alapú megközelítései . . . . . . . . 29

3.1.4.1. A metonímia kognitív nyelvészeti értelmezésének kezdete:

George Lakoff és Mark Johnson a metonímiáról. . . . . . . . 29

3.1.4.2. A tartománymátrix szerepe a metonímia értelmezésében . . . 30

3.1.4.3. A metonímia mint referenciapont-szerkezet . . . . . . . . 30

3.1.4.4. A metonimikus leképezések lehetséges típusai. . . . . . . . . 33

3.1.4.5. Cél-a-forrásban és forrás-a-célban metonímiák . . . . . . . . 34

3.1.4.6. A metonímia mint kiemelés: Klaus-Uwe Panther és Linda L.

Thornburg metonímiaértelmezése . . . . . . . . . . . 35

3.1.5. Összegzés . . . . . . . . . . . . . . . . . . 37

3.2. A metafora . . . . . . . . . . . . . . . . . . . . . . 37

3.2.1. Bevezetés . . . . . . . . . . . . . . . . . 37

3.2.2. A metafora meghatározásai, megközelítései az ókorban és a középkorban . . . . . . . . . . . . . . . . 38

3.2.3. A metafora az újkori felfogásokban . . . . . . . . . . . . . . . 40

3.2.3.1. Max Black a metaforáról . . . . . . . . . . . . . . . . 40

3.2.3.2. Kiindulópont a kognitív metaforaelmélethez: George Lakoff Mark Johnson a „hétköznapi metaforákról” . . . . . . . . . . 41

3.2.3.3. Fogalmi tartományok: forrástartomány, céltartomány . . . . . 42

3.2.3.4. A metaforaalkotás mint aktív folyamat. . . . . . . . . . . 42

3.2.3.5. Az invarianciaelv . . . . . . . . . . . . . . . . . . . 4 43

3.2.3.6. Lakoff „kiterjesztett metaforaelmélete” . . . . . . . . . . . . 44

3.2.3.7. A metafora mint kategorizációs aktus: Sam Glucksberg -

Boaz Keysar elmélete. . . . . . . . . . . . . . . . . . 45

3.2.3.8. A metafora Kövecses Zoltán-féle, jelentésfókuszon alapuló elmélete. . . . . . . . . . . . . . . 46

3.2.3.9. A Lakoff-Johnson-féle ,standard" metaforaelmélet kritikája: Joseph Grady alapmetafora-elmélete. . . . . . . . . . . . . 47

3.2.4. Összegzés . . . . . . . . . . . . . . . . . . . . . . . 48

3.3. A fogalmi integráció (blend) . . . . . . . . . . . . . . . . . . . . . . 49

3.3.1. A mentális terek és a fogalmi integrációs elmélet bemutatásának célja . 49

3.3.2. A mentális tér . . . . . . . . . . . . . . . . . . . . 49

3.3.3. A fogalmi integráció. . . . . . . . . . . . . . . 50

3.3.4. A blendben megjelenö terek . . . . . . . . . . . . . . . . . 51

3.3.5. A blend létrehozásában szerepet játszó múveletek . . . . . . . . . 52

3.3.6. Optimalitási feltételek . . . . . . . . . . . . . . . . 53

3.3.7. A fogalmi integrációs hálózatok (blendek) típusai . . . . . . . . . 54

3.3.8. A fogalmi integráció elméletének továbbfejlesztése:

Ruiz de Mendoza Ibáñez modellje . . . . . . . . . . . . . . . . . 54 
3.3.9. Blend és metonímia, blend és metafora . . . . . . . . . . . . . . 55

3.3.10. Összegzés . . . . . . . . . . . . . . . . 56

4. ELEMZÉSEK . . . . . . . . . . . . . . . . . . . . . 57

4.1. Az elemzések célja . . . . . . . . . . . . . . . . . . . . 57

4.2. Az elemzések módszertana. Az elemzendő szemantikai jellemzők . . . . . . 57

4.3. A kérdőíves felmérésekröl . . . . . . . . . . . . . . . . . . . . . 58

4.4. A jelen fejezetben közölt esettanulmányok bemutatásának okai, indokoltsága . . . . . . . . . . . . . . . . . . . . . 59

4.5. Az elemzendö neologizmusok részletes vizsgálata . . . . . . . . . . . 60

4.5.1. 1. esettanulmány: csokoholista . . . . . . . . . . . . . . 60

4.5.2. 2. esettanulmány: tanorexia, tanorexiás . . . . . . . . . . . . . 63

4.5.3. 3. és 4. esettanulmány: két -szitter utótagú összetétel elemzése . . . . 68

4.5.3.1. 3. esettanulmány: kutyaszitter . . . . . . . . . . . . . . 68

4.5.3.2. 4. esettanulmány: dédiszitter . . . . . . . . . . . . . . 71

4.5.4. 5. esettanulmány: gerillakertész. . . . . . . . . . . . . . . . 73

4.5.5. 6. esettanulmány: kanapészörf . . . . . . . . . . . . . . . . . . 77

4.5.6. 7. esettanulmány: passzívház . . . . . . . . . . . . . . . . 80

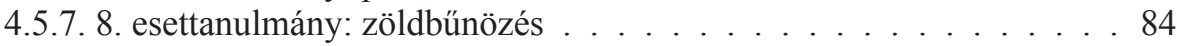

4.5.8. 9. esettanulmány: bagolyvonat . . . . . . . . . . . . . 886

4.5.9. 10. esettanulmány: kormányablak. . . . . . . . . . . . . . . . 91

4.5.10. 11. és 12. esettanulmány: e-könyv, e-könyv olvasó . . . . . . . . . . 95

4.5.11. 13. és 14. esettanulmány: be igekötős igék elemzése . . . . . . . . . 99

4.5.11.1. 13. esettanulmány: betámad . . . . . . . . . . . . . . . . 100

4.5.11.2. 14. esettanulmány: becéloz . . . . . . . . . . . . . . . . . 104

4.6. Összegzés ． . . . . . . . . . . . . . . . . . . . . . . 110

5. ÖSSZEGZÉS, KITEKINTÉS ． . . . . . . . . . . . . . . . . . . . . 111

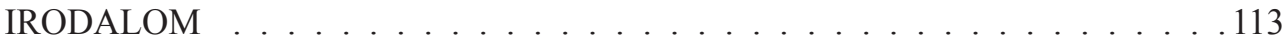





\section{ELŐSZÓ}

A nyelvet használó egyént folyamatosan változó világ veszi körül. A szellemi és tárgyi világban bekövetkező változások sok tekintetben jelentős hatással vannak az emberi gondolkodásra és a nyelvhasználatra. Az emberi kommunikáció, a társas interakciók során az egyén nyelvhasználatában igyekszik alkalmazkodni a kommunikációs szituáció tényezőiből fakadó elvárásokhoz: saját gondolatait, megnyilatkozásait jól érthetővé, hatásossá vagy éppen eredetivé, képszerüvé próbálja tenni.

A fenti folyamatok eredményeképpen a nyelv életében olyan újszerü jelenségek jelennek meg, amelyeket a szakirodalom a neologizmus fogalmával illet. Bár a jelenség definiálása, illetve annak meghatározása, hogy adott időpillanatban mit és milyen kritériumok alapján lehet neologizmusnak tekinteni, meglehetösen problematikus, a legtöbb nem nyelvészeti érdeklődésủ nyelvhasználó maga is felismeri a nyelvhasználatban megjelenő újszerủ nyelvi jelenségeket. A neologizmusokkal kapcsolatban több meghatározás, gyüjtemény és csoportosítási elv is született az idők során, magyar és idegen nyelven egyaránt. A megközelítések sokasága azonban az idők folyamán a szempontok, csoportok keveredéséhez is vezetett.

A jelen munka funkcionális-kognitív keretben vizsgája néhány, a megadott (munka)definíció értelmében neologizmusnak tekinthető alakulat szemantikáját. A neologizmusok szemantikai felépítésében, vagyis végső soron abban, hogy egy új jelenséget, fogalmat, tényállást vagy folyamatot hogyan nevezünk meg a nyelv segítségével, alapvető fontosságú a nyelvhasználók kognitív és társas tevékenysége, illetve e tevékenység folytán felhalmozódó előzetes tudása, nyelvi tapasztalata. A kognitív folyamatok, asszociációk és a jelentésképzést támogató mentális tevékenység vizsgálatára, modellálására adekvát és grafikus módon is jól ábrázolható lehetőséget nyújthat a neologizmusok szemantikai szerkezetének vizsgálata és kérdőíves felmérések vonatkozó eredményeinek beépítése a vizsgálatba. A fenti jelenségek, problémakörök áttekintése után a mü ezekre a folyamatokra és szemantikai jellemzőkre mutat be esettanulmányokat.

A jelen munka 2012-ben megvédett doktori értekezésem átdolgozott változata. A doktori dolgozat elkészítésében nyújtott segítségért köszönettel tartozom témavezetőmnek, Tolcsvai Nagy Gábornak, opponenseimnek, Benczes Rékának és Pethő Józsefnek, elöopponensemnek, Heltainé Nagy Erzsébetnek, valamint az ELTE-n müködő Stíluskutató csoportnak, amelynek tagjai hozzászólásaikkal segítették munkámat, és amelynek tagjaként az OTKA K 81315 számú, „Kognitív stilisztikai kutatás” címü pályázat keretében a témához kapcsolódó kutatást folytathattam. Végül, de nem utolsósorban köszönöm férjem, Kürthy János türelmét és biztatását. 



\section{BEVEZETÉS: A KUTATÁS TÁRGYA, CÉLJA, INDOKOLTSÁGA, FELÉPÍTÉSE, MÓDSZERTANA ÉS ALAPFOGALMAI}

„az élő népek nyelve minden nyomon változik, s örökké fog változni” (Kazinczy 1960 [1819]: 196)

\subsection{A kutatás tárgya és célja}

A jelen munka a mai magyar nyelvben megjelenő neologizmusok egy csoportjának szemantikai felépítését vizsgálja funkcionális-kognitív keretben.

A magyar és idegen nyelvű szakirodalomban a neologizmusnak nevezett jelenségekkel kapcsolatban sokfajta megközelítés, definíció olvasható, és számos csoportosítási, felosztási javaslat is született az idők során. Ezek a meghatározások és osztályozások azonban sok esetben a szempontok keveredéséhez, illetve átfedésekhez vezettek, így nehezítették egy-egy új nyelvi jelenség létrejöttének, használatának tanulmányozását. A többféle megközelítés gyakran nehézkessé tette, hogy a nyelvben megjelenő neológ jelenségek keletkezésének, elterjedésének vagy eltünésének okait, a változást motiváló nyelvhasználói tevékenységet, a neologizmusok megjelenése mögött húzódó kognitív folyamatokat tanulmányozzuk.

A kutatás ezeknek az aspektusoknak a bevonásával vállalkozik néhány olyan neologizmus szemantikai szerkezetének feltárására, amely az elmúlt években jött létre a magyar köznyelvben. Az elemzendő jelenségek lexémák; található köztük összetétellel, többszörös összetétellel létrejött szó, valamint néhány be igekötős ige.

Az egyik cél a fenti szempontok alapján egy olyan dinamikus, a beszélö-hallgató viszonyát a kommunikációs helyzet függvényében rugalmasan figyelembe vevő (munka)definíció megadása a neologizmusokra, melynek értelmében az elemzett nyelvi jelenségek neologizmusnak tekinthetők.

A nyelvhasználóknak egy-egy neologizmushoz füződő viszonyát, a vizsgált szó (fel)ismertségét, szemantikáját és néhány esetben a jelenlétéhez kapcsolódó attitüdöket segítenek feltárni a 2006 óta, a mai napig több mint 1300 adatközlő részvételével végzett kérdőíves felméréseim, melyek közül a 4. fejezet elemzéseiben a 2008 és 2011 között kapott, 1072 adatközlötől származó vonatkozó adatokat közlöm.

A felmérések eredményeinek idézése különösen gyümölcsöző lehet a kutatás szorosan vett fő céljának, a kiválasztott neologizmusok szemantikai elemzésének szempontjából. Az adatközlők által megadott válaszokból ugyanis olyan értelmezési stratégiák és attitüdök rajzolódhatnak ki, amelyek segítségével modellálhatóvá válhat a jelentésképzés (jelentéskonstruálás) folyamata. E ponton hangsúlyozni kell, hogy ez a folyamat közvetlenül, egy-egy neologizmus esetében néhány száz adatközlő válaszai alapján nem tárható fel, de ez a jelen münek nem is célja. A kérdőíves felmérések adatainak idézése azért 
fontos és szükséges, mert az adatközlök tapasztalatait bevonva az elemzés szempontjai közé, hozzásegíthetnek a vizsgált neologizmusok szemantikai szerkezetének eredményesebb feltárásához. Ezt a célt szolgálja a választott elméleti háttér is, valamint a szemantikai elemzésekben közvetlenül is felhasznált fogalmi integrációs modell, melynek segítségével egy-egy neologizmus szemantikai szerkezetének grafikus ábrázolása is lehetővé válik.

\subsection{A vizsgált téma jelentősége, újszerüsége, a vizsgálat indokoltsága}

Neologizmusok a nyelvet használó emberek nyelvi tevékenysége során nap mint nap keletkeznek a nyelvben; a keletkező újdonságok közül egyesek meggyökeresednek, mások viszont hosszabb-rövidebb idő után eltünnek a nyelvhasználatból. Olyan jelenségről van tehát szó, mely a nyelv életében minden időben jelen van, és a nyelvi változás dinamikus folyamatában jelenik meg.

E jellemzőkből következik, hogy a neológ alakulatok (legyen szó szavakról, kifejezésekről vagy más nyelvtani formákról) tanulmányozása fontos és - nem utolsósorban - rendkívül izgalmas feladat: ezt bizonyítja, hogy a nem tudományos érdeklődésü, „hétköznapi” nyelvhasználó is sokszor felfigyel ezekre az új jelenségekre. A vizsgálat azokat a jelentésszervező folyamatokat és szemantikai jellemzőket igyekszik megragadni, amelyeknek segítségével bemutatható, mi játszhat egy-egy neologizmus értelmezésében, megértésében és használatában szerepet. Ezek a jellemzők feltehetően legalább olyan nagy mértékben befolyásolják egy-egy neologizmus „túlélésének”, elterjedésének esélyeit, mint az ismert alakulatokhoz kapcsolódó asszociációkat előhívó grammatikai felépítés, a rím vagy a jóhangzás.

A neologizmusok szemantikai szempontú vizsgálata azért is különösen indokolt, mert segítségével feloldhatóvá válhatnak azok az ellentmondások, amelyek a korábbi megközelítésekben és definíciókban megjelentek. A jelen munkában alkalmazott elemzési módszerrel, valamint a kérdőíves felmérésekben kapott vonatkozó eredmények beépítésével az elemzésekbe megvilágítható, miért „müködik” és gyökeresedik meg az egyik neológ jelenség a nyelvhasználatban, illetve miért „nem müködik” egy másik, és tűnik el nyomtalanul.

Összességében tehát a mủ a nyelvi változás egy mozzanatának tanulmányozására is kísérletet tesz egy adott nyelvállapot metszetének pillanatnyi helyzetét vizsgálva; mindezt pedig olyan, szinkrón szempontból aktívan létező neologizmusok szemantikai szerkezetét feltárva világítja meg, melyekkel kapcsolatban a nyelvhasználóknak, az adatközlőknek konkrét, „,hétköznapi” tapasztalatuk van.

\subsection{Elméleti háttér}

A kiválasztott neologizmusok szemantikai szerkezetének feltárására funkcionális-kognitív keretben kerül sor. A választott elméleti keret különösen alkalmas lehet az elemzett jellemzők tanulmányozására, hiszen a jelentést a nyelvet szervező tényezők közül 
elsődlegesnek tekinti, és hangsúlyozza, hogy a nyelv tapasztalati alapú, és a mentális megismerés része (Langacker 1987: 13).

\subsubsection{A funkcionális nyelvészet}

A különféle funkcionális irányzatoknak közös jellemzőjük, hogy a nyelvi müködést nemcsak nyelven belüli, hanem nyelven kívüli, külső jellemzőkkel is magyarázzák. A funkcionális nyelvészet ,a nyelvet alapvetően nem elvont szabályrendszernek tekinti” (Tolcsvai Nagy 2010: 11, kiemelés tőlem - S. R.), hanem olyan jelenségnek, mely ,az emberi kommunikációban megvalósuló, jelentéseket hozzáférhetővé tevő aktuális nyelvi struktúrák konvencionális hálózata" (Ladányi - Tolcsvai Nagy 2008: 24). A funkcionális nyelvészet általános elméleti tételei a következők: 1 . a nyelvi rendszer kisebb és összetett elemeit a mindenkori beszélő nézőpontjából kell bemutatni, 2. a nyelvi kifejezéseket jellegzetes, gyakori közegükben kell leírni, nem önmagukban, 3. a jelentés egyenrangú az alakkal, sőt egyes magyarázatokban a jelentés az elsődleges (Tolcsvai Nagy 2010: 11).

A funkcionális nyelvészeti megközelítésnek fontos jellemzője a használatalapúság. Mivel a nyelv elvont struktúráit nem lehet a használattól függetlenül leírni, alapvető fontosságú a nyelvi szerkezetek és megvalósulásaik, a példányok, továbbá a gyakoriság, a tapasztalat és a tanulás tanulmányozása (Tolcsvai Nagy 2010: 13, kiemelések tőlem - S. R.). E megközelítés szerint a nyelv tehát tudás, amely a világról alkotott tapasztalatai alapján, a megismerési módok adta lehetőségek szerint rendeződik el a nyelvhasználó elméjében.

\subsubsection{A kognitív szemantika}

Az 1950-es és 1960-as években a megismeréstudománynak több területen - a pszichológiában, a szociológiában vagy az antropológiában - megjelentek olyan válfajai, amelyek kognitív elvek alapján a megismerés fontosságát, valamint az elme müködésének tanulmányozását vették alapul. A kognitív nyelvészet ezen elvek alapján az elmemüködés és a nyelv kapcsolatát, a nyelvet mint az elmemüködés egyik megjelenését, képességét vizsgálja. Kialakulása a nyelvészet úgynevezett pragmatikai vagy kognitív fordulatához kapcsolódik, melynek eredményeképpen a vizsgálódásokban elötérbe került a feldolgozás, a nyelv müveleti aspektusa (Tolcsvai Nagy 2000: 494) és a szemantika (Hámori 2009: 17-18).

A kognitív nyelvészet hangsúlyozza a nyelvi jelentés elsődlegességét, valamint azt, hogy nemcsak a nyelvröl való tudást kell vizsgálni, hanem magára a nyelvre a tudás egy fajtájaként kell tekinteni (Geeraerts 2006: 3). A kognitív szemantika ,az emberi megismerésre alapozott jelentéstan" (Tolcsvai Nagy 2010: 13), mely hangsúlyozza, hogy ,[a] nyelvi szerkezetek a világ egyes dolgait, viszonyait és folyamatait az emberi megismerésben fogalmi konstruálások révén, alapvetően szemantikai szerkezetekben képezik le és teszik mások számára hozzáférhetővé” (Tolcsvai Nagy 2010: 13). 
A kognitív nyelvészet két fö ága, a modularista és a holista kognitív nyelvészet közül a jelen munka a holista felfogáshoz kötődik, és a szemantikai vizsgálódások terén elsősorban Langacker, Lakoff, Johnson, Fauconnier, Turner és Sweetser, illetőleg Tolcsvai Nagy, Kövecses és Benczes munkáira, megállapításaira támaszkodik. A holizmus értelmében az emberi elme funkcionális területei, melyek között átjárás lehetséges, analóg módon dolgozzák fel az észlelés eredményeit; az általuk feldolgozott közvetlen tapasztalatokra pedig jellemzö, hogy közvetlenül részei a nyelvi ismereteknek, és segítenek az elvont ismeretek kialakításában (Geeraerts 2006: 5-6, Tolcsvai Nagy 2010: 14). 


\section{TÉMAFELVETÉS; A NEOLOGIZMUS TÖBB SZEMPONTÚ DEFINIÁLÁSÁNAK SZÜKSÉGESSÉGE}

A téma szempontjából kulcsfontosságúnak számít annak elhatárolása, pontosítása, hogy mit értünk a neologizmus fogalmán. A nyelvben megjelenő új szavak, kifejezések vizsgálata esetében nem hagyható figyelmen kívül a nyelvi változás folyamata, az, hogy „módosul(t) valami a nyelvben” (Kiss-Pusztai 2003: 23). Ennek a folyamatnak a megragadása, bevonása a vizsgálatba a neologizmusok esetében nélkülözhetetlen, ugyanakkor ez adja a neologizmus jelenségével kapcsolatos definíciók heterogenitását, gyakran látványos különbségeit is.

Az itt következő rövid történeti áttekintés azt mutatja be, milyen megközelítési módok, meghatározások születtek az idők során a „neologikus” nyelvhasználattal kapcsolatban. A bemutatást időrendben teszem, de a jelen fejezetben az időrendi áttekintésben csak azokat a munkákat, megállapításokat emelem ki, amelyek azokban a korokban keletkeztek, amikor a neologizmusok jelenségének tárgyalása kulcsfontosságú volt. A neologizmusjelenséghez kapcsolódó definíciók bemutatásával párhuzamosan utalok a meghatározásokból fakadó hiányosságokra is, amelyek elsősorban a neologizmus jelenségének rögzített, mozdulatlan jelenségként való szemléletéből fakadnak. Ezután bemutatom, a kognitív nyelvészeti megközelítés alapján, hogyan vonható be a neologizmusok jelenségének vizsgálatába a nyelvi változás folyamata és a „neologikus” nyelvhasználat dinamikus, nyelvhasználófüggő vizsgálata. A fejezet végén a fenti áttekintés lezárásaképpen kerül sor a jelen müben használt definíció megadására.

\subsection{Fogalomtörténeti áttekintés: a neologizmus fogalmának értelmezése a korábbi szakirodalomban}

\subsection{1. Ókor}

Az ókorban a stilisztika diszciplínája még nem vált el élesen a retorikáétól, az ókori retorikákban azonban sok esetben megjelenik annak a jelenségnek a taglalása, bemutatása, melyet ma gyakran neologizmusként jellemez a szakirodalom. A szöveg létrehozásának fázisai közül az elocutión belül tárgyalták a „neologikus” nyelvhasználatot. A szónoki beszéd esetében a neologizmushasználat gyakran egyéni alkotásként, hapax legomenonként jelent meg. Az érvelő és a díszítő funkció ez esetben egyszerre volt jelen, s bár a neologizmusok használata kezdetben pusztán a mủvészi nyelvhasználatra szo- 
rítkozott, már az ókorban megsejtették magának a neológia jelenségének általánosabb érvényét (Kozocsa 2008: 425).

Arisztotelész a Poétikában a következőképpen definiálja a neologizmust: „Új szóalkotás az, amit - anélkül, hogy valaha is használta volna bárki - a költő kialakít" (idézi Kramer 2003: 212). Cornificius C. Herenniusnak írt Retorikájának (i. e. 80-as évek) negyedik könyvében, a szóalakzatok témakörében jellemzi a neologizmusokat. Megállapítása szerint a neologizmus ,abban áll, hogy ha valaminek nincs neve vagy nem eléggé megfelelő a neve, magunk találjunk rá megfelelő szót, akár hangutánzás, akár jelentésátvitel révén” (Cornificius 2001: 105). Hozzáteszi: „ezzel az alakzattal ritkán kell élnünk, nehogy a gyakori új szavak visszatetszést keltsenek. Ám ha megfelelően és ritkán alkalmazzuk, nemcsak hogy nem bántó az újdonság, hanem még ékesíti is a beszédet" (Cornificius 2001: 105).

Cicero De oratore (A szónokról) címü munkájának (i. e. 55) harmadik könyvében, a 37-38. alfejezetben jelenik meg az „új szóalkotások” tárgyalása: „Új szavak úgy keletkeznek, hogy vagy attól születnek és lesznek, aki elsőként mondja őket, vagy szóösszetétel által" (Cicero 2012: 424). Elöbbiek esetében a befogadó érzékelheti, hogy nem természetes, hanem mesterséges szóalkotásokról van szó (tulajdonképpen a hapax legomenon jelentésben).

Quintilianus Szónoklattanában (i. sz. 94-95 k.) a hatodik fejezetben, a szóképek között tárgyalja az új szavak alkotását, az onomatopoiiát (onomatopoezist). A metafora, a metonímia és a szinekdoché tárgyalása után tér rá a neologizmusok témakörére, melyről megállapítja, hogy „,a görögök a legnagyobb erények között emlegetik, számunkra (ti. a rétorok számára) alig van megengedve" (Quintilianus 2008: 553). Legfőbb típusaiként a szóalkotást, a szóképzést és a szóösszetételt nevezi meg (Quintilianus 2008: 553). Az ókori meghatározásokat olvasva feltűnő, hogy ezek a munkák elsősorban a neologizmusnak nevezett jelenségek típusainak, lehetséges csoportjainak bemutatására törekednek. Az általuk bemutatott példákban - retorikai munkákról lévén szó - elsősorban a szónok alkalmazta neologizmusokról esik szó. Nem foglalkoznak tovább ezeknek az új jelenségeknek a további életével, sorsával; Quintilianus az első, akinek a leírásában megjelenik az, hogy a nyelvi változás dinamikusságának következtében természetes folyamat a neologizmusok meggyökeresedése vagy éppen eltünése a nyelvböl.

\subsubsection{A neologizmus fogalmának változása a felvilágosodás előtt és alatt}

Európában a felvilágosodás koráig a retorikakönyvek az elokvencia témakörében, az ornatus eszközeként tárgyalták a neologizmusokat. A 12. századtól kezdve nőtt a francia kultúra és a francia nyelv hatása, ugyanakkor a latin hatás továbbra is érvényesült az új szavak és kifejezések létrehozásában (Kramer 2003: 212). A középkor végén a folyamatokat felgyorsították a bibliafordítások támasztotta igények, majd a könyvnyomtatás feltalálása. A barokk korban fóként a metaforikus jelentésszerkezetủ neologizmusok terjedése volt jellemzö; ezek jól megfeleltek a korízlés által megkövetelt díszítettség kívánalmának (Kramer 2003: 213). A 18. században élénk vita alakult ki a neológia jelenségéről; 
a vizsgálat Franciaországból indult, és a neologizmus fogalmának megalkotásához vezetett (az elnevezés Desfontaines Dictionnaire néologique à l'usage des beaux esprits du siècle címü, 1726-ban megjelent munkája nyomán terjedt el). A neologizmus terminus technicus immár nem csupán az ornatus szolgálatában állt, új tényállások megnevezésére is használni kezdték (Kramer 2003: 213-214), a 19. századtól pedig az írói és a költői neologizmusok aránya nőtt meg igen nagy mértékben (Kozocsa 2008: 426).

\subsubsection{A neologizmusok tárgyalása a vonatkozó magyar szakirodalomban - 18-19. század}

Verseghy Ferenc Bevezetésében (1793) kiemeli: elegendő, ha az idegen nyelvekből csak azokat a szakkifejezéseket gyüjtjük össze, amelyek a magyar ragozáshoz leginkább alkalmazkodnak.

Révai Miklós A magyar szép toll (1805) címủ munkájában Az újságról címszó alatt tárgyalja az ,újjságokat”. A neologizmusok létrejöttéhez vezető okok között első pontként említett tény, a „léleknek újságra való vágyása” már arra utal Révai felosztásában, hogy a tudományos, technikai fejlödéshez hasonlóan fontos szerepet játszik egy-egy neologizmus kialakításában az emberi gondolkodás változása, a megújulásra való folyamatos hajlam és törekvés.

A nyelvújítás időszaka témánk szempontjából is kulcsfontosságú, mivel azonban a jelen munka napjaink neologizmusaival foglalkozik, itt nincs rá lehetőség, hogy az említett korszak elképzeléseit, vitáit részletesen tárgyalja. Azt azonban mindenképpen ki kell emelni, hogy ebben a korszakban (tehát az 1772-től 1867-ig/1872-ig tartó időszakban) mind az ortológusnak, mind pedig a neológusnak nevezett tábor képviselői a korábbinál nagyobb figyelmet fordítottak a magyar nyelv kérdésein belül az új szavak keletkezésének módjaira, lehetőségeire (Fábián 1984: 28-31). Az egymással gyakran igen ellentétes vélemények mind kitértek a nyelvi változásra és annak kérdésére, hogy lehet-e, szabad-e vagy kell-e tudatosan beavatkozni ezeknek a változásoknak a folyamataiba (erröl részletesen lásd Fábián 1984: 28-66).

A nyelvi változással és az új szavak, kifejezések megjelenésével kapcsolatban Kazinczy Ferenc több megjegyzést is tesz Ortológus és neológus nálunk és más nemzeteknél címü összegző munkájában (1819). Ebben utal arra, hogy minden élő nyelvre jellemző a változás: „Egyedül a kiholt nép nyelve nem változik többé: az élő népek nyelve minden nyomon változik, s örökké fog változni” (Kazinczy 1960 [1819]: 196). Több alkalommal utal arra az elvre, hogy „a beszéd célja az, hogy értessék” (Kazinczy 1960 [1819]: 204), valamint a szituációnak, a szövegkörnyezetnek a fontosságára, amelyben vizsgálni kell egy-egy új jelenséget: ,az új szót és új szólást a beszéd egész szövedékében kellene vizsgálat alá vennünk, s nem soha abból kikapva" (Kazinczy 1960 [1819]: 203).

Kazinczynak már a nyelvi változások elméletei felé mutató gondolata az egyén és a közösség szerepének, egymáshoz való viszonyának bemutatásaként értelmezhető a nyelvhasználat dimenziójában: eszerint a nyelv ugyan minden nyelvhasználóé, de az egyénnek is aktív szerepe van a változások előidézésében: „A nyelv miénk és így enyém is. Az egész társaság folyamjával az egész társaság parancsol” (Kazinczy 1960 [1819]: 205). 


\subsubsection{Definíciók, felosztások a 20-21. századi magyar és külföldi szakirodalomban}

A 20. században a neologizmussal kapcsolatos definíciók, jellemzők mind a rövidebb tanulmányokban, lexikonok szócikkeiben, mind pedig hosszabb terjedelmü stilisztikakönyvek fejezeteiben megjelennek.

Terestyéni Ferenc 1955-ben írt, két részből álló tanulmányában („A neologizmusok kérdéséhez”) rámutat a neologizmuskutatás nyilvánvaló adósságaira is: ,a neologizmusok mivoltának, fajainak és a velük kapcsolatos kérdéseknek a vizsgálatára és tisztázására nem fordítottunk megfelelő figyelmet” (Terestyéni 1955: 297-298). A definíciót, melyet a neologizmusok meghatározásaképpen közöl, a vonatkozó szakirodalom az elkövetkező időkben sok esetben többé-kevésbé változatlan formában átveszi: „A neologizmus - azt mondhatjuk - meghatározott korban, a nyelv fejlődésének bizonyos szakaszában a szókészletbe és kifejezéskészletbe különböző okokból bevezetett új értelem, értelmi árnyalat, illetőleg a nyelvi rendszerben létrejött új kifejezési forma, amely vagy magával hozza a nyelvi kifejező készletben való megszilárdulás igényét, vagy nem" (Terestyéni 1955: 299). A neologizmusok létrejöttének részletezésében kiemeli annak fontosságát, hogy a neológ jelenségek keletkezésének okait és körülményeit vizsgálni kell. Az okok között első helyen emeli ki „az emberi gondolkodásban, a nyelvet beszélö közösség társadalmi életében bekövetkezett differenciálódást" (Terestyéni 1955: 300). Szemantikai szempontból fontos megállapítása, hogy sok alkalmi és állandósult újdonság keletkezik a nyelvben a szavak metaforikus és metonimikus használatának köszönhetően (Terestyéni 1955: 299). Rámutat arra is, hogy e jelenségek vizsgálata során nyomon kellene követni egy-egy neologizmus sorsát, elterjedésének, illetve elszigetelődésének folyamatát is; azt, hogy „milyen mértékben van befolyással az elterjedésre a közösség tudatában, gondolkozásában történt változás" (Terestyéni 1955: 466-467).

A magyar stilisztika vázlata címü könyv (1958) a következőképpen határozza meg a neologizmus fogalmát: „A nemzeti nyelvrendszer a társadalmi viszonyok és a gondolkodás fejlődésével párhuzamosan szakadatlanul gazdagodik új szavakkal, kifejezésekkel, jelentésárnyalatokkal, nyelvtani formákkal. Ezek az új nyelvi tények a neologizmusok" (Terestyéni 1958: 48). Ez a felosztás a neologizmusoknak három nagy csoportját (fogalmi, jelentésbeli és formai neologizmus) különbözteti meg (Terestyéni 1958: 48).

Zsemlyei János munkájában (1996) a fenti felosztást némiképpen kiegészítve négy csoportot - új szavak (pl. hütöszekrény), fogalmi (pl. mühold), jelentésbeli (pl. poloska 'lehallgatókészülék' jelentésben) és formai (pl. matek) neologizmusok - különít el a neologizmusok rendszerén belül (Zsemlyei 1996: 25).

Neologizmusdefiníciók, csoportosítási lehetőségek a legtöbb retorikával, stilisztikával és irodalommal foglalkozó lexikonban, szótárban találhatók. A meghatározási nehézségeket jól mutatják a fenti változatos csoportok, illetve az a módszertani nehézség, mely a nyelvben megjelenő neologizmusoknak az egyes csoportokba való besorolásával kapcsolatban jelentkezik.

Minya Károly 2003-as könyvének elején rámutat: „a neologizmus fogalmának, mivoltának meghatározása problémát okoz. Sokféle nyelvi tényre vonatkoztatva használjuk a neologizmus elnevezést, s ezeket a nyelvi jelenségeket nehéz egyetlen, valamennyit 
felölelő meghatározásba belesüríteni” (Minya 2003: 13). E bizonytalanság feloldására a neologizmusok két fö szempont szerinti csoportosítását javasolja: 1. a neologizmusok keletkezésének célja, 2. a neologizmusok keletkezésének módja (Minya 2003: 14). E két nagy csoporton belül alcsoportokat is megkülönböztet, a következöképpen: a neologizmusok a keletkezés célja alapján a) szükségszerü, b) stilisztikai neologizmusok, míg a keletkezés módja alapján a) szooösszetétellel, b) szóképzéssel, c) elvonással, d) szóvegyüléssel, e) mozaikszó-alkotással, f) rövidüléssel, g) jelentésbővüléssel létrejött neologizmusok, valamint h) idegen szavak és i) lexéma értékủ szószerkezetek lehetnek (Minya 2003: 14).

Az újabb szakirodalmi források közül a Stilisztikai lexikon (2004) neologizmusdefiníciója a következőképpen hangzik: „Neologizmusok azok az új szavak, kifejezések, jelentésárnyalatok, nyelvtani formák, amelyekkel a nyelv, a társadalmi viszonyok és a gondolkodás fejlődésével párhuzamosan, állandóan gazdagodik" (Szathmári 2004: 154). Fajtáiként - csakúgy, mint A magyar stilisztika vázlata - a fogalmi, jelentésbeli és formai neologizmusok csoportjait nevezi meg. A lexikon a neologizmusokat - a Minya-féle felosztáshoz hasonlóan - a stilisztikai felhasználás szempontjából is csoportosítja: e szerint a szempont szerint megkülönbözteti az alkalmi (hapax legomenonok), a nyelvben hosszabb-rövidebb ideig élő, de meg nem szilárduló (pl.feketézni), illetve az állandósult (pl. e-mailezik) neologizmusok csoportjait (Szathmári 2004: 155).

Az Alakzatlexikon mind a neologizmus, mind az archaizmus (Heltainé 2008: 127-132) jelenségét részletesen tárgyalja. A neologizmus szócikk a Stilisztikai lexikonhoz hasonlóan definiál. A neologizmusoknak hat alcsoportját különíti el: fogalmi neologizmusok (pl. füstérzékeló), jelentésbeli neologizmusok (pl. király), formai neologizmusok (pl. szobroz), grammatikai neologizmusok (pl. kell menjek szerkezet), olyan neologizmusok, amelyek nem tudtak megszilárdulni a nyelvben (pl. tanácselnök), állandósult neologizmusok (ezek egy ideig újnak számítottak, majd megszilárdultak a szókészletben, pl. TAJ-szám) (Kozocsa 2008: 427).

A 20-21. századi nem magyar nyelvủ szótárak, lexikonok neologizmusdefiníciói is a jelenség új jellegét emelik ki (vö. a Current Literary Terms [Scott 1965], Dictionary of world literary terms [Shipley 1970], A dictionary of literary terms [Cuddon 1977], A dictionary of stylistics [DS], illetve a Metzler Literatur Lexikon [Schweikle-Schweikle], Sachwörterbuch der Literatur [Swb], Historisches Wörterbuch der Rhetorik [Ueding 2001], valamint a Dictionnaire des Termes Littéraires [DTL] vonatkozó meghatározásait). A leírások utalnak a neologizmusok csoportosíthatóságára (Kramer 2003: 210), valamint arra, hogy a szókészletben megjelenő neologizmusok egy része idővel lexikalizálódik, míg mások hapax legomenonok (nonce words) maradnak (DS 317).

\subsection{A neologizmusdefiníciókból fakadó ellentmondások, hiányosságok}

A fenti definíciók elsősorban arra törekednek, hogy csoportosítási lehetőségeket adjanak meg, amelyek segítségével a nyelvben megjelenő neologizmusok rendszerezhetők. Magát a neologizmust mindegyik bemutatott megközelítés igyekszik definiálni: új szóként, jelentésként, nyelvtani formaként stb. határozza meg. 
Bár a fenti felosztások alapján sok esetben jól osztályozhatók a keletkező új szavak, kifejezések, nyelvi rendszerbeli jelenségek, e szempontok több problémát is felvetnek. Ezek közül a jelen mủ vizsgálati tárgya szempontjából az egyik problémás terület a neologizmusok és a nyelvet használó egyének tudásának viszonya, e viszony tanulmányozása. A nyelvhasználók elözetes tudásának, tapasztalatainak figyelembevétele elengedhetetlennek tủnik a neologizmussá nyilvánítás esetében; ez az igény ugyanakkor - mivel logikus módon nagyszámú nyelvhasználó, illetve kommunikációs szituáció előfordulása lehetséges - egyben rá is mutat a „neologizmusnak ítélés” relatív voltára.

Problémásnak tünik az „új szó” vs. „új fogalom” distinkció is. Zsemlyei említett, 1996-os munkájának felosztásánál maradva, megállapítható, hogy mind a hütőszekrény, mind a mühold új szóként tünt fel a nyelvben egy adott időpontban, azonban míg az előbbi entitás megnevezésére már volt egy szó (frizsider) a szókészletben, utóbbi esetében egyáltalán nem létezett ilyen. A Minya által javasolt „keletkezés célja” (Minya 2003: 14) dimenzió vizsgálatánál gyakran felmerülő probléma, hogy mely új megjelenések és milyen szempontok alapján tekinthetők ,szükségszerü”-nek, és melyeket tartjuk pusztán „stilisztikai”-nak. E felosztás azt sugallhatja, hogy - mivel a „szükségszerü” neologizmusok létrejöttére feltétlenül szükség van, a „stilisztikaiaknak” viszont csak „stilisztikai” funkciójuk van - a stílus pusztán járulékos, kiegészítő elem lenne, és nem venne aktívan részt a jelentésképzés folyamatában a neologizmus létrejötte, illetve értelmezése során.

Mindenképpen szükséges a szituációs kontextus - a személyközi viszonyok, illetve a térbeli és időbeli viszonyok - (Tátrai 2004: 480; 2011: 51-55) vizsgálata is, vagyis az, hogy miért és hogyan használja a beszéló és a hallgató az adott szituációban azt a nyelvi alakulatot, amit használ. Egy ilyen jellegü vizsgálat pedig akár ahhoz az eredményhez is vezethet, hogy - a Minya-féle definícióval élve - bizonyos szituációban (adott beszélö, hallgató és kommunikációs céljaik esetében) „szükségszerü”, míg más esetben csupán „stilisztikai” funkcióban jelenik meg ugyanazon szó, kifejezés vagy nyelvtani forma.

A fent részletezett meghatározások felosztásai nemcsak a nyelvhasználótól függő viszonylagosság szempontjából, hanem a jelen munka központi elemzési szempontjának, a neologizmusok szemantikai felépítésének szempontjából is sok esetben problematikusak lehetnek: több felosztás megvizsgálásakor megjelenik például a jelentésszervező folyamatok funkcióinak keveredése, valamint a poliszémia és a szinonímia kérdésének tisztázatlansága.

Terestyéni 1958-as felosztásában a ,jelentésbeli neologizmusok” csoportja (2. csoport, Terestyéni 1958: 48) esetében valószínúleg sok esetben poliszémia jön létre, amikor egy meglévő szónak „új, képes értelme” (Terestyéni 1958: 48) alakul ki. Megjegyzendö, hogy a „képes értelem” létrejöttének folyamatában szemantikai szempontból gyaníthatóan sokszor metonimikus vagy metaforikus jelentésváltozás játszódik le. Feltehetően hasonló folyamatok zajlanak annak a csoportnak az esetében is, amelyet Zsemlyei szintén ,jelentésbeli neologizmus"-nak nevez (3. csoport, Zsemlyei 1996: 25). A szerző poloska példájánál maradva elmondható ugyanis, hogy szemantikai szempontból nem lehet véletlen, hogy éppen a 'lehallgatókészülék' új jelentése alakult ki a szónak: a poloska nevü élőlény bizonyos tulajdonságainak (méretének, formájának, élősködő voltának) 
kiemelésével jött létre az új jelentés. Itt átfedés tapasztalható az úgynevezett fogalmi neologizmusok (2. csoport, Zsemlyei 1996: 25) csoportjával, hiszen az előző példánál maradva a poloska nevet felvevő lehallgatókészülék is új tárgyként jelent meg, csak a megnevezés hiányát nem egy formai szempontból új alakulat, hanem egy már meglévő hangsor töltötte be - annak oka, hogy ez így alakult, viszont egyértelmüen szemantikai.

A másik, szemantikai szempontból releváns és ezért vizsgálandó jelenség a bemutatott meghatározások viszonylatában a szinonímia. E jelenséggel kapcsolatos probléma jelenik meg a „formai neologizmus”-nak (Terestyéninél a 3., Zsemlyeinél a 4. csoport) nevezett jelenségek csoportjánál: attól, hogy egy szónak az alakján történik változás (mint Zsemlyei matematika-matek példájában, Zsemlyei 1996: 25), sok esetben nem maga a megnevezett entitás változik, hanem a nyelvhasználóknak a megnevezett tárgy, jelenség, folyamat stb. iránt táplált attitúdje módosul. Ezt a változást is érdemes a kommunikációs szituációban megfigyelni, hiszen nagymértékben függhet tőle, hogy a megnevezni kívánt entitást a nyelvhasználó hogyan fogja megnevezni. Szintén a szinonímia kérdéséhez kapcsolódik a Zsemlyei által bevezetett „új szavak” csoport mibenléte (Zsemlyei 1996: 25). Szemantikai szempontból ezekben az esetekben a megnevezett entitás nem változott meg, mindössze egy újabb szó alakult ki a megnevezésére. Zsemlyei a hütöszekrényt hozza példaként (mely a frizsider szóval is megnevezhetö): ebben az esetben a szóhasználat által elért stílushatás fog megváltozni attól függően, hogy melyik alakulatot használja a nyelvhasználó, hiszen nem arról van szó, hogy a korábbi elnevezés nyomtalanul eltủnt volna a nyelvből, mindössze egy másik segítségével is megjelölhető a kérdéses entitás.

\subsection{Kísérlet a neologizmus több szempontú definiálására}

A fenti alfejezetekben bemutatott dimenziók alapján a következőkben egy olyan neologizmusdefiníciót adok meg, amely mind a közlő, mind a befogadó, mind a cél- és a jóváhagyó struktúra, mind az idő dimenziója szempontjából meghatározza, hogy e kutatás keretein belül mi tekinthető neologizmusnak.

A neologizmus olyan újszerủ szerkezeti felépítésü nyelvi jelenség, melynek egy adott közlö és/vagy egy adott befogadó adott szituációban előzetes (vagy ilyen hiányában elözetesként értelmezett) tapasztalataihoz, ismereteihez és az ezekből fakadó elvárásaihoz viszonyítva újszerủ jelentést és/vagy újszerü stílust tulajdonít. E jelentés- és stílustulajdonítás dinamikus, a fenti változók függvényében skalárisan módosulhat egyazon nyelvhasználó esetében is (vö. Sólyom 2012c: 268; 2013: 152).

A jelen munkában vizsgált neologizmusok olyan szavak, amelyek az ezredforduló óta eltelt időszakban jelentek meg nyelvünkben. A tárgyalandó jelenségeket - az öket tartalmazó kontextus meglétének fontossága miatt - a 4. fejezetben internetes forrásokból (fórum- és kommentszövegekből, valamint egy blogbejegyzésből) származó szövegekben mutatom be. 


\subsection{A nyelvi változás dimenziójának bevonása a neologizmusok vizsgálatába}

A fentiekböl következik, hogy a neologizmusok jelenségének vizsgálatakor nem hagyható figyelmen kívül az a - kétségkívül kézenfekvőnek tünő, ám több kérdést is felvetö - tény, hogy a nyelvet nyelvhasználók használják, és e használatból következöen, ha kell, alakítják, módosítják is; így jön létre a nyelvi változásnak nevezett jelenség. A nyelvtörténeti vizsgálatok a nyelvi változást hagyományosan a tényezők, okok vizsgálatával modellálják. Erre utal a nyelvhasználat úgynevezett kettős beágyazottsága, vagyis a „nyelvrendszertani tényezők, tehát a változásban érintett nyelvi elemek, jelenségek nyelvrendszertani adottságai, viszonyai”, illetve „a társadalmi (társas, szociokulturális) tényezők" vizsgálata (Kiss-Pusztai 2003: 23).

A nyelvi változásnak nyelvelméleti irányzatoktól függően többféle megközelítése terjedt el, ilyen például az újgrammatikus irányzat vagy a történeti (variációs) szociolingvisztika (részletesen lásd Croft 2000: 53-63; Kiss-Pusztai 2003: 26-28).

Az új szavak és kifejezések, illetve új jelentések létrejöttének vizsgálatakor érdemes kiemelni a Keller által a nyelvi változás folyamatára alkalmazott „láthatatlan kéz” elméletét. Az elméletet Keller olyan jelenségek magyarázatába vonja be, amelyek szándékos egyéni cselekvések véletlen eredményeként jöttek létre, és legalább részben hasonló intenciókat tartalmaznak, mint az eredeti egyéni cselekvések (Keller 1990: 96-97, idézi Croft 2000: 59). A változás tehát olyan módon következik be, mintha egy láthatatlan kéz irányítaná, és anélkül zajlik, hogy az egyes egyéneknek szándékában állna létrehozni.

A fentieket az új szavaknak, kifejezéseknek vagy éppen a szókészletben már meglevő alakulatok új jelentéseinek a kialakulására is vonatkoztathatjuk: amikor a nyelvet beszélők közössége elkezd használni egy neologizmust, az soha nem egyik napról a másikra történik, hanem időben, térben és a nyelvhasználók kommunikációs céljaitól és szociológiai tulajdonságaitól (életkorától, végzettségétől, lakóhelyétől stb.) függően változik.

A láthatatlan kéz elméletének értelmében a félreértések elkerülése érdekében a beszélők különböző egyértelmű szinonimákat használnak; a félreérthető, homályos forma viszont kikopik a használatból, a beszélők következő generációi nem fogják elfogadni. Ez történt például a német englisch szóval is, amelynek korábban több jelentése volt, ma viszont már csak egyetlen, 'angol' jelentése él, míg az 'angyali' jelentést az engelhaft szó reprezentálja (Keller 1990: 109-111).

A neologizmusok esetében is gyakran előfordul ehhez a példához hasonló jelentésváltozás, ráadásul - mint az a korábban bemutatott szakirodalmi források tipizálásából is látható - sok más típus (idegen eredetü szó, belső szóalkotás, rövidítés, képzés stb.) is megjelenik. A jelenség megragadásának nehézségeire utal a fenti példa által is érzékeltetett folyamatosság, dinamikusság, valamint az a tény, miszerint nem biztos, hogy az egyes nyelvhasználók direkt akaratának köszönhetően alakul ki az új jelenség. Egyszerübben regisztrálhatók azok az esetek, amikor egyértelmű (például törvényhez, alkalmazás megkezdéséhez köthetö) az újdonság megjelenése (ilyen volt például 2011 elején a kormányablak szó megjelenése), más esetben viszont az új jelentés elterjedése és így az is, hogy végül meggyökeresedik-e a neologizmus a nyelvben, vagy nem, hosszabb ideig, akár évekig elhúzódik (ilyen például a becéloz ige új, 'rosszindulatú megjegyzést tesz' jelentése). 


\subsection{A kognitív nyelvészeti megközelítésből fakadó lehetőségek}

A kognitív nyelvészet a nyelv alapvető funkciójából indul ki, eszerint a nyelv nyelvi kifejezések útján történő alkotás és megértés (Tolcsvai Nagy 2005a: 22-23). Langacker 1987-es munkájában alapvető elvként megállapítja szintaxis és szemantika elválaszthatatlanságát (Langacker 1987: 1), és kiemeli: a nyelv az emberi kogníció elválaszthatatlan része, a jelentés pedig nem mesterséges, müvi, hanem szerves, élő jelenség (Langacker 1987: 12).

A további fejezetekben elemzendő jelenségek értelmezéséhez célszerünek tünik néhány, a kognitív nyelvészeti megközelítés lehetőségéből fakadó alapfogalmat tisztázni.

\subsubsection{Konceptualizáció}

A kognitív nyelvészeti megközelítés lényeges fogalma a konceptualizáció: „A jelentés konceptuális (fogalmi), a fogalmak pedig a tapasztalat absztrakciói” (Tolcsvai Nagy 2005a: 23), ${ }^{1}$ a jelentés tehát „fogalmi természetủ és tapasztalati alapú” (Tolcsvai Nagy 2013: 55). A különböző nyelvi kifejezések ily módon egy dolgot, viszonyt, folyamatot vagy eseményt konceptualizálnak (Tolcsvai Nagy 2005a: 23). E megállapítás a neologizmusok definiálása szempontjából is fontos megközelítési lehetőséget tartalmaz - ilyen szemszögből vizsgálva egy-egy új jelenséget a nyelvben, megfigyelhetővé válik, hogy milyen „problémamegoldás” (Langacker 1987: 65; 2000: 9) eredményeképpen jön létre az alakulat a kommunikációs helyzetben.

\subsubsection{Kategorizáció}

E ponton érdemes felvenni a szempontok közé a kognitív nyelvészetben is megjelenő, pszichológiai alapokon nyugvó összehasonlítás képességét. A kognitív nyelvtan értelmében ,a prototípusmodell nyelvi és kognitív szempontból is figyelemre méltó módon plauzibilis" (Langacker 1987: 17), hiszen a kategorizáció, melynek leírása már Arisztotelésznél megjelent (Kövecses-Benczes 2010: 27), különösen kiemelkedő szerepet foglal el a kognitív nyelvtanban.

A világ megismerésében, az elme világról alkotott képének kialakításában, a tapasztaltak feldolgozásában döntő szerepe van a prototípuselvnek (Tolcsvai Nagy 2005b: 7; 2013: 115-121). Ennek jellemzője, hogy egy-egy kategóriába bizonyos felismert tulajdonságok alapján sorol be az elme példányokat, a besorolás alapja pedig elsősorban a Wittgenstein-féle családi hasonlóság. A kategóriákon belül léteznek középponti, ,jó” vagy „legjobb” példányok (prototípusok) és kevésbé jók (melyek kevesebb, a kategóriára jellemzö tulajdonsággal rendelkeznek). Utóbbiak a központi példány körül he-

A magyarul nem publikált művekből származó idézetek fordításai a szerzőtől valók. 
lyezkednek el, így a besorolás fokozat kérdése. Ráadásul a kategóriák körvonalai nem határozottak: elmosódottak lehetnek, és át is fedhetik egymást, valamint folyamatosan változhatnak is (Langacker 1987: 17; Tolcsvai Nagy 2005b: 7). A prototípus-alapú kategorizáció modelljének elméletét Wittgenstein nyomán Austin terjesztette ki a szavak jelentésére, melyekről azt állította, hogy szintén egy-egy prototípus köré szerveződnek (Kövecses-Benczes 2010: 28-29), majd 1969-ben Berlin és Kay (Berlin-Kay 1969, idézi Tolcsvai Nagy 2010: 26), az 1970-es évek közepén pedig Rosch végzett pszicholingvisztikai kutatásokat e téren (Rosch 1977; 1978). Az elv az 1980-as évek óta egyre fontosabb szerepet tölt be a nyelvészeti szemantikában, például az úgynevezett kognitív kiterjesztésben (Geeraerts 2002: 284-285).

A prototípuselv mellett a másik irányító művelet az alapszintú kategorizáció (Tolcsvai Nagy 2005b: 12; 2013: 121). Eszerint a világban létező dolgokat nemcsak a kategóriáknak megfelelően, hanem egymáshoz is viszonyítjuk, méghozzá egy olyan skálán, ahol az egyik végponton egy teljesen általános, a másikon pedig egy egyedítő tudományos kategória áll (Tolcsvai Nagy 2001a: 47). Az úgynevezett alapszintủ kategória ennek a hierarchiának a középtáján helyezkedik el, és az egyéni és kulturális különbségeknek megfelelően változhat (Tolcsvai Nagy 2005b: 12; Kövecses-Benczes 2010: 46-47). E modellből következik, hogy ,igen gyakori jelenségnek számít a nyelvben, hogy a szavak teljes jelentése egy-egy prototipikus jelentésböl és annak metafora vagy metonímia útján levezethető, periférikusabb jelentéséből tevődik össze" (Kövecses-Benczes 2010: 30).

Akkor, amikor adott szituációban valamilyen új, neológ jelenség használatára vállalkozik a beszélő/író, a világ egy adott entitásának definiálására tesz kísérletet korábbi tapasztalatai alapján. Amennyiben egy-egy új nyelvi forma létrejöttét a kategorizáció szempontjából vizsgáljuk, világossá válik, hogy e jelenségek létrehozása nem különül el élesen az emberi elme problémamegoldó, folyamatos, kreatív müködésétől, hanem szervesen beilleszthető ennek az aktív müködésnek a kontinuumába: ,a prototípus ismerete könnyebb hozzáférést tesz lehetővé a használatban megjelenő olyan periférikus példányokhoz, amelyek újak számunkra" (Geeraerts 1997: 110). A prototípuselv implikálta jelenségek az emberi gondolkodás dinamikusságának leírása által tehát a szemantikai változásoknak és így az új jelentések kifejlődésének is magyarázatául szolgálhatnak (Geeraerts 1997: 115). Ezek a jelenségek egyrészt a nyelvhasználók számára begyakorlottnak, konvencionálisnak tekinthető formáktól térnek el bizonyos mértékben (vö. Langacker 1987: 369), másrészt pedig, az idő stílusváltozójának aspektusát (Tolcsvai Nagy 1996: 148) figyelembe véve, újszerúségükben skalárisan különböznek a közlő vagy a befogadó által közömbösnek érzett nyelvhasználattól.

\subsubsection{Előtér-háttér}

Azáltal, hogy a verbális interakcióban egy adott szituációs kontextusban megjelenik egy-egy nem konvencionálisnak tekinthető alakulat, a nyelvhasználók figyelmének elöterébe kerülhet. A Gestalt-pszichológia részletesen foglalkozik a figura-alap (alak- 
háttér) észlelésével: ez az elrendezés egyrészt az entitások térbeli elhelyezkedésének vizsgálatakor játszik szerepet, másrészt viszont ugyanezen az alapon a szövegben bizonyos elemek kiemelkedö, feltünőbb helyzetbe kerülhetnek, mint a többi (Tolcsvai Nagy 2001a: 48; 2013: 139-144; Kövecses-Benczes 2010: 149).

Amikor a beszélö/író valamilyen okból úgy dönt, hogy újszerü elemet alkalmaz, a befogadó figyelmét bizonyos irányba tereli (úgy, mintha metaforikusan egy ablakon vagy kereten át zajlana mindez - mutat rá Langacker [2001: 144-145]). Ha azt szeretné, hogy a befogadó megértse a közlést, az adott szituációban figyelembe kell vennie a befogadó fent említett elözetes ismereteit, és dönthet úgy is, hogy újszerü alakulatot alkalmaz. Azok az igények, körülmények, amelyek miatt a neológ elemek alkalmazására sor kerülhet, nagyon különbözőek lehetnek - erre utalt a szakirodalomnak a korábbi (gyakran átfedésekhez is vezetö) felosztása, amelyben a neologizmusokat „fogalmi”-nak, ,jelentésbeli”-nek vagy éppen „szükségszerü”-nek vagy „stilisztikai”-nak nevezte.

\subsubsection{Konvencionalizáltság és kreativitás}

A neologizmusok megjelenésének vizsgálata a nyelvhasználatban szoros kapcsolatban van az intézményesült, megszilárdult formák, konvenciók jelenlétével. „A konvencionalizáltság arra utal, hogy valamit jelentős számú individuum birtokol - sőt, észlelik is, hogy birtokolják. (...) Csakis akkor van komoly esély arra, hogy [egy új szó] belekerüljön egy nyelv nyelvtanába, ha elterjed a beszélöközösségben” (Langacker 1987: 62). $\mathrm{Az}$ „elterjedés” azonban mindig időbeli, térbeli és nyelvhasználóktól függő tényezők függvényében vizsgálható; éppen ez okozza a neologizmus meghatározásával kapcsolatos problémákat. A kérdés az, hogy vajon azok a nyelvi jelenségek, amelyek egy-egy ilyen alcsoportot alkotnak, vagy hapax legomenonként, esetleg szójátékként jelennek meg a szépirodalom vagy a reklámok nyelvében (Pethő 2009: 220-221; Sólyom 2012c: 290-294; 2013: 160-163), tekinthetők-e neologizmusnak. Feltételezhetően igen, hiszen mindegyik típus esetében megvan a lehetőség arra, hogy újabb és újabb befogadók találkozzanak vele, és új jelenségként értékeljék őket - függetlenül attól, hogy a későbbiekben szélesebb körben elterjedtté válik-e a neologizmus a beszélöközösségben.

A (köznyelvi vagy szépirodalmi) hapaxok esetében a figyelem felkeltése, az egyéniség kiemelése, alkalmanként pedig a nyelvi humor a cél - adott esetben még akkor is, ha ez ellentmond a gazdaságosságnak, és a befogadót nagyobb mentális erőfeszítésre kényszeríti: „Mindazonáltal az a szokatlan a legtöbb új blendben és egyéb divatos neologizmusban, hogy nem növelik a közlés hatékonyságát. Valójában nagyobb erőfeszítésre van szükség a megértésükhöz - legalábbis első alkalommal, amíg az olvasók és a hallgatók kitalálják, hogy mik a forrásszavak, és mit jelentenek" (Lehrer 2003: 369). 


\subsubsection{Célstruktúra és jóváhagyó struktúra}

A fentiekhez érdemes hozzávenni a célstruktúra és a jóváhagyó struktúra fogalmát (Tolcsvai Nagy 2001a: 48): a közlö és a befogadó az interakció során létrejövő megnyilatkozást mint célstruktúrát összeveti az általa konvencionálisnak tekintett (konvencionálisként elsajátított) jóváhagyó struktúrával. Sok esetben elképzelhető, hogy csak részleges megfelelés van a jóváhagyó struktúra és a célstruktúra között; nem is feltétlenül szükséges, hogy a kettő teljesen lefedje egymást: minél jobban különbözik egy struktúra a prototípus jellemzőitől, annál kevésbé valószínű, hogy beleolvad a kategóriába (Langacker 1987: 69). Másrészt viszont tény, hogy minél közelebb áll egymáshoz a célstruktúra és a jóváhagyó struktúra, annál gyorsabban történik meg a jóváhagyás.

Ha a fentieket a neologizmusok definiálásának problémájára vetítjük, megmagyarázhatóvá válnak azok a nehézségek, melyekkel a szakirodalom a jelenség leírásakor küzd: az, hogy egy újszerü szó, kifejezés, nyelvtani forma stb. milyen mértékben lesz neológ a befogadó számára, nagymértékben múlik magán a befogadón, de függ az egyedi jóváhagyó struktúráját befolyásoló tényezőktől és a kontextus mint „támogató mátrix” (Tolcsvai Nagy 2010: 12) jelenlététől is. Lehetséges tehát, hogy egy adott jelenséget az egyik befogadó neologizmusként értelmez, míg egy másik nem.

\subsection{6. Összetett sémák müködése a fogalmi konstruálás folyamatában}

Általánosságban elmondható, hogy az emberi megismerés következtében kialakuló fogalmi konstruálást egyszerü vagy összetett sémák, „,nyelvi kifejezések dekontextualizált, elvont szerkezete[i]” (Tolcsvai Nagy 2010: 16, 38), „nyelvi szerkezetek konvencionált és begyakorlott, alapbeállítású formái” (Tolcsvai Nagy 2013: 152) segítik. A neologizmusok megértési módjai esetében a sémák megléte támogathatja egy-egy új szó vagy kifejezés értelmezését, megértését és meggyökeresedését is a nyelvhasználatban. Összetett sémának tekinthető a tudáskeret, mely „egy központi fogalom köré elrendezett tudáselemek készlete” (Tolcsvai Nagy 2010: 43; 2013: 153), és a forgatókönyv, mely „egy nyelvi és nem nyelvi cselekvésekből álló interakció lefolyásának menetét, az interakció társadalmi intézményeit tartalmazza” (Tolcsvai Nagy 2010: 43; 2013: 153).

Kintsch - van Dijk (1978) alapján elmondható, hogy a szöveg makroszintjén érvényesülő makroszabályokat általános sémák irányítják, melyek egyben azt is biztosítják, hogy miközben a nyelvhasználó a segítségükkel a szöveg jelentését megkonstruálja, a szabályok nem válnak túl általánosakká vagy puszta jelentés nélküli absztrakciókká. A szövegben megjelenő neologizmusok értelmezésének szempontjából lényeges kiemelni, hogy amennyiben az olvasott (hallott) szöveg struktúrája nem konvencionális, minden egyes olvasó különféle sémákat állíthat fel a szöveg interpretálása során; ezeknek az elérési útvonalaknak a száma a nyelvhasználók számának ismeretlensége miatt nem jósolható meg elöre (Kintsch - van Dijk 1978: 373). A szöveg befogadóinak problémamegoldó tevékenysége során esetlegesen előforduló interpretálási hibákra, inkonzisztens adatokra pedig tipikusan jellemző, hogy ezek is a szöveg értelmezésének folyamatában szerepet 
játszó séma hatókörén belül jelennek meg (Kintsch - van Dijk 1978: 375). A hálózat nyelvhasználófüggő jellegéből adódik, hogy a hálózat kiterjedtsége, felépítése, aktiválhatósága „,személyre szabott”, vagyis egyénenként igen eltérö lehet.

Az újszerü elemet tartalmazó közlés körülményeivel, illetve a séma és az instanciáció fogalmával kapcsolatban meg kell említeni a Fillmore-féle keretszemantika (frame semantics) elméletét (Fillmore 2006 [1982]). Charles J. Fillmore bevezeti a keret fogalmát, mely azt a szituációt, jelenetet, motivációs kontextust adja meg, amelyben a nyelvhasználóknak lehetőségük nyílik rá, hogy az adott nyelvi alakulatot, kategóriát használják. Bizonyos keretek velünk születettek, míg mások tapasztalat vagy gyakorlás útján sajátíthatók el, és vannak olyan esetek is, amelyek csak egy adott nyelvhasználatban léteznek (pl. a mértékegységek vagy a naptár egységei) (Fillmore 1985: 232-233).

Ha a neológ nyelvi jelenségeket, illetve a neologizmusok és a konvencionális nyelvhasználat viszonyát ebben a dimenzióban vizsgáljuk, láthatóvá válik, hogy a beszélö/író célja ezeknek az alakulatoknak a használatával az, hogy a saját (felismert) motivációs kontextusát megértesse és elterjessze, hosszú távon pedig keretté alakítsa, begyakorlottá és így mások számára is könnyen interpretálhatóvá tegye (erre utal Turner is, amikor felhívja rá a figyelmet, hogy a blendet a nyelvhasználók tudatos erőfeszítés nélkül interpretálják - Turner 2007: 378).

Másrészt viszont vannak olyan esetek, amikor a felidézni kívánt motivációs kontextus vagy csak egy szükebb befogadói réteg számára nyújt könnyü hozzáférhetőséget az alakulat jelentéséhez, vagy a közlő célja éppen az, hogy oly módon keltse fel a befogadó figyelmét, hogy nagyobb mentális erőfeszítésre ösztönzi - ezekben az esetekben nem a begyakorlottság státuszának elérése a cél, ellenkezőleg: a figyelem felkeltése és a megjelenő alakulatra irányítása - ez figyelhető meg például a már említett hapax legomenonok esetében.

\subsection{A szleng jelenségének viszonya a neologizmusokhoz}

Egy-egy újszerủ nyelvi jelenség megértése és neologizmusként való megítélése tehát erősen nyelvhasználófüggő lehet. Tény, hogy ez az eltérés nemcsak az idő dimenziójában, hanem a beszélő/író nyelvhasználathoz kötődő céljaiban és attitüdjében is megjelenhet - így lehetséges az, hogy a köznyelvben megjelenő újszerủ alakulatok között szép számmal akadnak a szleng stílusváltozatba sorolandók. A nyelvhasználó célja a fent említett esetekben stílusának egyedivé tétele és/vagy a nyelvi játék, sok esetben a humor kifejezése, a stílus élénkítése. A szleng meghatározásakor erre a célra utal Kiss is: „A szleng nem egyetlen csoport tulajdona, kiváltsága, nyelvváltozata (...) feladata nem a titkosság (...), hanem rétegekhez nem kötődő, a köznyelvi stílus variálására, élénkítésére lehetőséget adó kifejezéskészlet, illetőleg nyelvhasználati mód. Alkalmat ad a nyelvhasználat egyénítésére, a beszélő személyiségének a kiemelésére" (Kiss 1995: 81). 


\subsection{A közlő és a befogadó stílustulajdonítása}

Annak vizsgálatakor, hogy az alkalmazott alakulat neológnak tekinthetö-e, vagy sem, meg kell vizsgálni a beszélö/író és a hallgató/olvasó stílustulajdonítását. A stílus szociokulturális tényezői (Tolcsvai Nagy 1996: 134-175; 2005a: 85-105; 2012: 19-49) közül a jelen vizsgálódás szempontjából meg kell említenünk az idő dimenzióját, mely a neologizmusok esetében újszerünek tekinthető: „Idő szerint újszerü egy szöveg stílusa a beszélő vagy a hallgató stílustulajdonításában, ha az adott szöveg valamilyen, szerintük általában vagy az adott cselekvésben, szituációban, kontextusban újszerünek minősülö nyelvi elemet (elemeket) tartalmaz. Az újszerủ stílusminősítés mindig időviszonyon alapul" (Tolcsvai Nagy 1996: 151). A neologizmusjelenség megítélésének dinamikussága, „mozgása” tehát részben a stílustulajdonítás nyelvhasználófüggő voltából fakad. 


\title{
3. ELMÉLETI ÁTTEKINTÉS: \\ A VIZSGÁLANDÓ SZEMANTIKAI SZERKEZETEK
}

\begin{abstract}
A következő alfejezetek azokat a jelentésszervező szemantikai szerkezeteket tekintik át, amelyek segítséget nyújtanak a vizsgált neologizmusok 4 . fejezetben olvasható elemzéseiben. A tudománytörténeti áttekintések esetében hangsúlyozni kell, hogy a bemutatandó munkák, megközelítések nem minden esetben szemantikaiak, azonban létezésükkel és hatásukkal igen jelentős mértékben hozzájárultak a vizsgálandó jelenségek szakirodalmának teljességéhez.
\end{abstract}

\subsection{A metonímia}

\subsubsection{A metonímia az ókorban és a középkorban: a retorikai hagyomány}

A metonímia elnevezés a görög 'névcsere', 'átnevezés' szóból ered; a szónoki beszéd létrehozásának fázisai közül a metonímiát az ókorban az invenció és az elokúció lehetöségeként tartották számon (Kocsány 2008b: 410). Az első metonímiadefiníció Cornificiustól származik, aki a Herenniushoz irt retorikában a következőképpen határozza meg: „A metonímia szomszédos és közeli fogalmak nevét veszi át, és általa megérthetjük azt a dolgot, amelyet nem saját nevével neveztünk meg" (idézi Eggs 2001: 1196; Kocsány 2008b: 410).

Quintilianus a fentiek alapján építette ki a helyettesítéselméletet, miszerint egy $\mathrm{A}_{\mathrm{y}}$ kifejezést, mely y dolgot hivatott kifejezni, egy $\mathrm{A}_{\mathrm{x}}$ kifejezés segítségével nevezünk meg: innen eredt a metonímia névátvitelként ismert megközelítése (Eggs 2001: 1197).

Cicero az Oratorban (A szónok) a metonímiát mutataként, felcserélt szavakként definiálta: ebben az esetben a tulajdonképpeni szó helyett egy másik áll, mely - minthogy egy rákövetkező dologból származik - hasonlót kell, hogy kifejezzen (Eggs 2001: 1199; Cicero 2012: 428-430). A későbbi szerzőknél a metonímia gyakran mint átnevezés, transnominatio jelenik meg, így Donatus, Charisius és Beda is ennek a megközelítésnek megfelelően tárgyalja; Isidor pedig Cornificius meghatározásához nyúl vissza. Mindeközben megfigyelhető, hogy az egymással versengő metonímiameghatározások mellett egyre gyakrabban jelenik meg a jelenség összehasonlítása a metaforával: ha a metaforát átvitelként (translatio) értelmezzük, akkor a metonímia esetében inkább helyettesítésről van szó? 


\subsubsection{Metonímiaértelmezések a reneszánsztól a felvilágosodásig}

Eggs (2001) a metonímiával kapcsolatos megközelítéseket két nagy csoportra osztja a 16-18. századig terjedő időszakban: az egyik csoport azt a kanonikus ókori felosztást követte, amely a metonímiának különböző típusait, alcsoportjait különítette el; a másik megközelítés képviselői viszont Petrus Ramus elképzelése alapján a trópusoknak négy fajtáját különböztették meg (ezek voltak a metonímia, az irónia, a metafora és a szinekdoché).

A tradicionális felosztást követők - például Lamy vagy Delminio - az ókori minta és a Herenniushoz írt retorika alapján különbséget tettek metonímia és szinekdoché között. A metonímia alcsoportjai között - csakúgy, mint az ókori felosztások - megkülönböztették az 1. feltaláló-találmány, 2. tulajdonos-tulajdon, 3. ok-hatás, 4. tartály-tartalom kategóriákat. Elkülönítették továbbá a szinekdoché egyes típusait is, úgymint: 1. rész-egész, 2. egyes szám - többes szám, 3. nem-fajta. Cyprianus Soarius (1524-1593) az ok-hatás és a tartály-tartalom kategóriák mellett az 1. jelkép - jelképezett dolog és a 2. előzménykövetkezmény kategóriáját is bevezette (utóbbit ő szinekdochéként tartja számon) (Eggs 2001: 1205-1206).

Dumarsais szóképeket tárgyaló munkájában (Traité des Tropes, 1730) a metonímia és a szinekdoché jelenségét egymástól elkülönítve, szisztematikusan tárgyalja. Csoportosításában a fenti felosztásokhoz képest az alábbi új alcsoportok jelennek meg: 1. az előállítás helye a termék helyén, 2. jel a jelzett dolog helyén, 3. absztrakt név a konkrét név helyén, 4. testrész az érzés helyén, 5. a ház urának neve a ház neve helyén.

A másik megközelítés első képviselője Petrus Ramus volt, aki a metonímiát az alapvető trópusok egyikeként nevezte meg, és így definiálta: „a metonímia az ok-hatás, illetve a szubjektum (...) és az esetleges következmény (...) felcserélése” (idézi Eggs 2001: 1208). Ennek az elképzelésnek megfelelően a metonímia összekötő trópusként, összekapcsoló eszközként jelenik meg Fontanier Figures du Discours címú munkájában (1821/1830): „Az összekötő trópusok esetében egy dolgot egy másik dolog nevével jelölünk” (idézi Eggs 2001: 1211).

\subsubsection{A metonímia értelmezései a 19. századtól kezdve Lakoff-Johnson megközelítéséig}

A 19. századi megközelítések - Reisig Historische Sprachwissenschaftja (1839) és Darmesteter értelmezése (1887) - a tradicionális trópusfelosztást veszik alapul, mely a metaforát, a metonímiát és a szinekdochét mint a jelentésváltozás lényeges folyamatát vizsgálja (Eggs 2001: 1213).

A nyelvhasználók szerepének kiemelése a szóképek tárgyalása kapcsán először Hermann Paul megközelítésében jelent meg (1908): a beszélőközösség által elindított, majd meghonosított jelentésváltozás, melynek során ,az uzuális jelentéstartalom általános tapasztalat nyomán térben vagy időben vagy kauzálisan összekapcsolódik" a nyelvszokással, jelentésváltozáshoz vezet (idézi Eggs 2001: 1213). A Paul által hasonlóságként és 
érintkezésként megnevezett jelentésváltozást veszi át Ullmann is strukturalista megközelítésben: a név és az értelem megkülönböztetést felhasználva elkülönít névhasonlóságot és névérintkezést (Namensähnlichkeit und Namenskontiguität), értelemhasonlóságot és értelemérintkezést (Sinnähnlichkeit und Sinnkontiguität). A metaforát az értelemhasonlósághoz sorolja, a metonímiát pedig az értelemérintkezésen alapuló névátvitelként definiálja (Burkhardt 1996: 187; Eggs 2001: 1214). Jakobson nem a metafora és metonímia terminusokat használja, helyettük „metaforikus” szelekciós folyamatról és „metonimikus” érintkezési kapcsolatokról beszél. Lacan a metonímiát kb. „szó a szónak helyén" (mot à mot) értelemben definiálja, pusztán a jelölt szempontjából közelítve meg az érintkezés folyamatát (Eggs 2001: 1214-1215).

Az Ullmann, Jakobson és Lacan által bevezetett „hasonlóság” és „érintkezés” vizsgálata, mely a metafora és a metonímia elkülönítésének alapját adta, egészen az 1980-as évekig tartotta magát. A metonímiának és a metaforának a jelentésképzésben betöltött szerepét, azt az aspektust, melynek értelmében a metonímiát referenciális elmozdulásként extenzionális, a metaforát pedig az új jelentés létrehozásában intenzionális folyamatnak tekintjük, csak Le Guern és Lakoff-Johnson vetették fel először (Eggs 2001: 1215).

\subsubsection{A metonímia kognitív nyelvészeti alapú megközelítései \\ 3.1.4.1. A metonimia kognitív nyelvészeti értelmezésének kezdete: George Lakoff és Mark Johnson a metonímiáról}

George Lakoff és Mark Johnson 1980-ban megjelent Metaphors we live by címủ munkájában nemcsak a metafora, hanem a metonímia kognitív keretben való értelmezése is megjelenik. Kiindulópontjuk a következő: a metonímia esetében a metaforával ellentétben valamely entitás segítségével utalunk egy másik, vele kapcsolatban levő entitásra. Ennek a definíciónak az értelmében azokat az eseteket is metonímiának tekintjük, amelyeket a hagyományos retorikai tradíció a szinekdoché kategóriájába sorolt (LakoffJohnson 1980: 35-36).

A metonímia ugyanazokat a célokat szolgálja, mint a metafora (vagyis hozzásegíti a befogadót a megértéshez, egyben részt vesz a jelentés szervezésében), és lehetővé teszi, hogy a referált dolog bizonyos aspektusaira fókuszáljunk. Lakoff egy későbbi munkájában (Lakoff 1987) az idealizált kognitív modellek (ICM-ek, magyarul IKM-ek) egyik fajtájaként nevezi meg a metonimikus modellt, és hangsúlyozza: a prototípushatásoknak képezi az alapját, és - a metaforával ellentétben - egy fogalmi tartományon belüli múveletek soraként értelmezhetö (idézi Kövecses-Radden 1998: 38; Panther-Thornburg 2003: 2). Kövecses-Benczes a fogalmi tartományt „tapasztalataink bármely koherens szegmenséról alkotott fogalmi reprezentáció"-ként határozza meg (Kövecses-Benczes 2010: 223). A metonímia esetében tehát referenciális váltás történik egyazon kognitív tartományon belül (Panther-Thornburg 2007: 238). A hétköznapi nyelvben megjelenő metonímiákra Lakoff és Johnson néhány altípust is felsorol (ezekben - a kognitív nyelvészeti jelölésnek megfelelően - kiskapitális betütípus jelöli a fogalmakat, Lakoff-Johnson 
1980: 38), például: A RÉSZ AZ EGÉSZ HELYÉN (pl. Vidd innen a hátsódat!), A GYÁRTÓ A gYÁRTMÁNY HELYÉn (pl. Egy Fordot vett.), A HELY AZ INTÉZMÉNY hELYÉn (pl. Hollywood nem az, ami volt.).

\subsubsection{A tartománymátrix szerepe a metonímia értelmezésében}

Lakoff és Johnson meghatározásának továbbfejlesztéseként értelmezhető William Croft megközelítése. Croft (1993) bevezeti a tartománymátrix (domain matrix) fogalmát, amely mind a metafora, mind a metonímia értelmezésében és definiálásában alkalmazható. A tartománymátrix fogalma Langacker (1987) megközelítésére vezethető vissza, melynek értelmében egy kifejezés jelentését gyakran csak olyan, egymással átfedésben levő tartományok háttere ellenében lehet definiálni, amelyek egyben a kifejezés jelentésprofilálódásának is alapját biztosítják (idézi Panther-Thornburg 2007: 239). Croft ennek az elvnek az értelmében a metonímiát olyan jelenségként definiálja, melynél ez a leképezés ugyanazon a tartománymátrixon belül jelenik meg. A metonímia esetében ugyanakkor lehetséges az is, hogy egy tartománymátrixon belül elhelyezkedő tartományok közötti leképezést jelenítsen meg, abban az értelemben, hogy egy fogalom esetében a több, a fogalom jelentése által implikált olvasat közül valamelyik előtérbe kerül, kiemelödik. Ezt nevezi Croft tartománykiemelésnek (domain highlighting); ezekben az esetekben a metonímia interpretálásának folyamatában tehát a tartomány valamely kiemelt aspektusa dominál (Croft 1993: 348). Például a Proust fogalom a befogadó elméjében egyaránt előhívhatja az 'író mint személy' jelentést (szó szerinti jelentés) és 'a Proust nevü író müvei' jelentést is, így a váltás a két fogalmi tartomány, az ,alapértelmezett” 'író mint személy' és az ugyanehhez a tartománymátrixhoz tartozó 'a Proust nevü író múvei' között gyors és kreatív jelenség (Croft 1993: 348).

\subsubsection{A metonímia mint referenciapont-szerkezet}

A metonímia a kognitív nyelvészeti megközelítésben referenciapont-szerkezetként is értelmezhetö. A referenciapont-szerkezet olyan összetett jelentésszerkezet, melynek esetében egy dolog megértése egy másik dolog megnevezése, aktiválása során válik lehetségessé (Tolcsvai Nagy 2010: 79; 2013: 255-256). A referenciapont-szerkezet így mentális hozzáférést nyit meg a befogadó számára, miközben a közlő nézőpontját, megközelítését is közvetíti. „A referenciapont jelensége annyira alapvető és mindenütt jelen levő az emberi tapasztalásban, hogy meglétét a legtöbb esetben nem is észleljük" (Langacker 1993: 5).

Általános sémáját Langacker és Tolcsvai Nagy az 1. ábrával szemlélteti (az ábra forrása: Langacker 1993: 6; Tolcsvai Nagy 2010: 81; 2013: 256): az ábrán K a beszélő vagy a hallgató konceptualizációját, $\mathrm{R}$ a kiindulópontként szolgáló referenciapontot, $\mathrm{C}$ az elérendő fogalmi célt, $\mathrm{D}$ pedig azt a fogalmi tartományt (domíniumot) jelöli, amelyhez a referenciapont a hozzáférést megnyitja (Tolcsvai Nagy 2010: 80; 2013: 256).

Amennyiben a metonímia jelenségét referenciapont-szerkezetként értelmezzük, sok, a hétköznapi nyelvben használt kifejezésünkben megfigyelhetővé válik a megnyilatkozó 


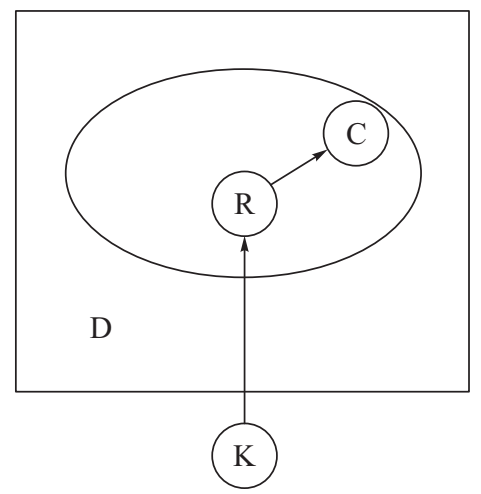

1. ábra: A referenciapont-szerkezet általános sémája

nézöpontja és az a domináns aspektus, amelyet a közlésben a megnyilatkozó ki akar emelni. „A metonímia uralkodó jelenség, mert a referenciapont-felhasználó képességünk alapvető és mindenütt jelen lévő, és első helyen tünik fel, mert hasznos kognitív és kommunikációs funkciót tölt be. Mi ez a funkció? A metonímia hatékonyan egyeztet össze két ellentétes tényezőt: a pontosság igényét, például azt, hogy a címzett figyelme a kívánt tárgyra irányul, és azt a természetes hajlamunkat, hogy explicit módon gondolkodjunk és beszéljünk azokról az entitásokról, amelyek a legnagyobb kognitív szalienciával bírnak számunkra" (Langacker 1993: 30). A következő példákban olyan rész-egész viszonyok szerepelnek, melyekben az emberi test, illetve az ember mint létező jelenik meg. Ezeket a metonímiákat a nyelvhasználók könnyedén interpretálják (Langacker 1993: 29):

(1)

Mindössze 1.50 \$-ért vette meg Lakoff-Johnsont, használtan, papírborítóban.

Ugyanakkor bizonyos esetekben nagy szerepe van a láthatóságnak is, csak így érvényesül az adott szerkezet szalienciája a beszédhelyzetben (Langacker 1993: 29-30):

Ez az autó nem tudja, hová megy.

A szaliencia nagymértékben függ a beszédhelyzettől, és ettől függően változhat a kommunikációban megjelenő metonímia jellege is: az, hogy egy adott entitásnak mely(ek) a legjellemzőbb tulajdonsága(i) a kommunikáló partnerek számára, a kommunikációs helyzetben dől el, és ugyanazon entitás esetében is változhat. Gondoljunk LakoffJohnson példájára, amelyben két pincér beszél az egyik vendégről a következőképpen (Lakoff-Johnson 1980: 35): 
(3)

A sonkás szendvics várja a számlát.

A fent említett két elv, a pontosság igényének és az explicit kifejezésmódra való törekvésnek a jelen kutatás témáját képező neologizmusok szemantikai szerkezetében, magának a neológ alakulatnak a megalkotásában és interpretálásában is fontos szerepe van, amennyiben aktív, problémamegoldó folyamatként tekintünk e jelenségekre. A pontosság és az explicit kifejezésre való törekvés elve magyarázatot adhat azokra az esetekre is, amikor egy új, a befogadó számára korábban ismeretlen elnevezés értelmezését nem a neologizmus megalkotójának értelmezése szerint hajtja végre a befogadó, tehát félreérti vagy nem is érti meg az alakulat jelentését a szándékolt jelentéshez képest. Ebben az esetben is feltételezhetően arról van szó, hogy a befogadó figyelme a szóban forgó entitásnak nem arra a tulajdonságára irányul, amit a beszélő/író ki szeretett volna emelni.

A metonimikus kiemelés szoros összefüggésben van az aktív zónának (active zone) nevezett jelenséggel: egy bizonyos viszony tekintetében egy entitás aktív zónája magában foglalja az entitásnak azokat a részeit, amelyek legközvetlenebb és legfontosabb résztvevői a viszonynak (Langacker 1993: 31). A következő mondatban például elsődlegesen a kutya fogai kerülnek az aktív zónába a harapás viszony megléte miatt (Langacker 1993: 31):

(4)

A kutya megharapta a macskát.

Ebben az esetben a kutya egyéb, a harapásban egyébként részt vevő testrészei (állkapcsa, izmai stb.) nem kerülnek az aktív zónába, csakúgy, mint a macska megharapott része sem, de ez a kommunikációs szituációban a közlés sikere szempontjából nem lényeges.

Az egy-egy neologizmus értelmezésével kapcsolatos befogadói stratégiák esetében a „téves” értelmezések - vagyis azok az esetek, amikor a nyelvhasználók a neologizmust nem a „prototipikus” jelentésében értelmezik, melyben kezdett elterjedni - hátterében gyakran az áll, hogy a befogadók az alakulat egészében vagy egy részében metonimikusan más, de a neologizmus jelentésével kapcsolatba hozható jelentésrészeket aktiválnak.

Az aktív zónával kapcsolatban le kell szögezni, hogy az nem feltétlenül alrésze az entitásnak, de a fogalmi tartományán (domíniumán) belül kell, hogy elhelyezkedjen. A következő mondat esetében például nem képezi az entitás részét a kiemelt aktív zóna (Langacker 1993: 32):

(5)

Benne vagyok a telefonkönyvben.

Az (5)-ös példa esetében természetesen nem maga a beszélő a fizikai valójában, hanem csak nevének, címének és telefonszámának grafikai megvalósulása van benne a telefonkönyvben. A referenciapont segítségével tehát ezekben az esetekben a figyelem 
fókuszálása változik a kontextustól függően; a figyelem áthelyeződése pedig - a metonímia fenti megközelítésének értelmében - egy fogalmi tartományon belül valósul meg (Tolcsvai Nagy 2010: 94-95).

\subsubsection{A metonimikus leképezések lehetséges típusai}

A metonímia kognitív nyelvészeti alapú (elsősorban Lakoff [1987] és Langacker [1993] munkáin alapuló) meghatározását Kövecses-Radden 1998 és Radden-Kövecses 1999 a következő módon adja meg: „A metonímia olyan kognitív folyamat, melyben egy fogalmi entitás, a közvetítő (melyet gyakran »forrás «-nak hívunk), ugyanazon a kognitív modellen belül biztosít mentális hozzáférést egy másik fogalmi entitáshoz, a célhoz" (Kövecses-Radden 1998: 39; illetve Radden-Kövecses 1999: 21, idézi Panther-Thornburg 2003: 3; 2006: 185). A két fogalmi entitás közötti távolság meghatározó lehet az alakulat megértése szempontjából: „A metonimikusan összefüggő közvetítőfogalmak és célfogalmak alapvető jellemzöje, hogy a fogalmi térben »közel« helyezkednek el egymáshoz: az alkotó az alkotáshoz, a szervezet földrajzi elhelyezkedése magához a szervezethez, az irányító az irányítotthoz" (Kövecses-Benczes 2010: 64).

Kövecses-Benczes a lakoffi idealizált kognitív modellek (IKM-ek) alapján a metonímiának több alcsoportját is megkülönbözteti; a felosztás két alapvető kategóriája az alapján különbözik egymástól, hogy RÉSZ ÉS EGÉSZ IKM-ek (SKÁLA, ÖSSZETÉTEL, KOMPLEX ESEMÉNY, KATEGÓRIA ÉS TULAJDONSÁG, KATEGÓRIA ÉS TAG) vagy RÉSZ ÉS RÉSZ IKM-ek (CSELEKVÉS, OKOZÁS, IRÁNYÍTÁS, TARTÁLY, LÉTREHOZÁS/ALKOTÁS, MEGHATÁROZATLAN KAPCSOLATOK) viszonyát fejti ki a létrejövő metonímia (Kövecses-Benczes 2010: 66-73).

Gibbs (1993) Lakoff-Johnson megközelítése alapján elismeri, hogy fogalmi rendszerünkben sokfajta metonimikus leképezést tartalmazó viszony kimutatható. Ugyanakkor Turner (1987) alapján kiemeli, hogy a lehetséges asszociatív viszonyokban fontos szerepet játszik a konvenció.

Hangsúlyozza továbbá a kontextus fontosságát a lehetséges metonímia létrehozásában (Gibbs 1993: 260): alkalmilag, ha a fizikai és a nyelvi környezet támogató körülményei ezt lehetővé teszik (tehát nem okoznak zavart a megértésben), sok hétköznapi metonímiát alkotunk (idézi Gibbs 1993: 260; Kleiber 1995: 108; Papafragou 1996: 174), például:

(6)

A buszok sztrájkolnak.

(7)

A buszok parkolójában parkoltam, mert túl nagy vagyok.

Ezek a metonímiák a hétköznapi nyelvhasználatban gyakran megjelenhetnek, és amennyiben az entitásnak olyan tulajdonsága, része emelődik ki, amellyel a befogadó korábban még nem találkozott, neológ elemként érzékelheti őket. Használatukkal a megnyilatkozó sok esetben nem vagy nemcsak az újszerüséget akarja kifejezni, hanem 
egyértelművé kívánja tenni megnyilatkozását az adott szituációban. A cél tehát az, hogy a befogadó figyelmét a lehető legpontosabban a megnevezni kívánt entitásra (személyre, tárgyra, tényállásra) irányítsa, és kizárja a tévedés, félreértés lehetőségét.

\subsubsection{Cél-a-forrásban és forrás-a-célban metonimiák}

Ruiz de Mendoza Ibáñez - Hernández (2001) problémásnak tartja a metonímiának azokat a megközelítéseit, amelyek a forrás- és a céltartomány között X Y HELYÉN relációt tartalmaznak. Az első problémát abban látják, hogy ilyen referenciális funkcióban nemcsak metonimikus, hanem metaforikus jelentésviszonyok is állhatnak. Elképzelhető ugyanis, hogy egy metaforikus kifejezés (pl. a DiszNó metafora) is azért alkalmazható egy ember jellemzésére, mert valamilyen szaliens tulajdonságát emeli ki (Ruiz de Mendoza Ibáñez - Hernández 2001: 323):

A disznó a számlára vár.

Ebben a mondatban, ha azt egy pincérnő mondja, akivel bizalmaskodott a vendég, a DISZNÓ metafora referenciális funkcióban jelenik meg; ez a tulajdonság tehát nem csak a metonimikus jelentésviszonyok jellemzője.

Másrészt elképzelhető az is, hogy metonimikus jelentésviszonyok is megjelennek nem referenciális funkcióban, mint a következő mondatban (Ruiz de Mendoza Ibáñez Hernández 2001: 323):

(9)

Ö csak egy csinos pofi.

A hasonló esetekben a kiemelt testrészek nem az egész ember helyett állnak, hanem annak valamilyen jellemzőjéről, képességéről vagy karakteréről árulnak el valamit. Ezek a tulajdonságok sok emberre jellemzőek lehetnek, így ezek nem referenciális használatai a metonímiának. Ruiz de Mendoza Ibáñez - Hernández a fentiek alapján feltételezi, hogy a metonímia (és a metafora) referenciális használata és a „helyettesítő” funkció között összefüggés van: a metaforák közül csak azok használhatók referenciálisan, amelyekben egyértelmü megfeleltetés van (mint a (8)-as példában), de a metaforák többfajta megfeleltethetőséget is tartalmazhatnak. A metonímiák referenciális használhatósága viszont annak köszönhető, hogy a metonímiák csak egyfajta megfeleltethetőséget tartalmazhatnak a leképezés során: ekkor ugyanis a forrásnak valamely attribútuma emelődik ki és kerül megfelelésbe a cél valamely attribútumával (Ruiz de Mendoza Ibáñez - Hernández 2001: 324-325).

A fentiek alapján Ruiz de Mendoza Ibáñez - Hernández (2001) a metonímiának két altípusát különíti el: az egyik az, amikor a céltartomány a forrástartomány altartománya (target-in-source metonymy, cél-a-forrásban metonímia), mint a következő esetben: 
(10)

Megkötötte a cipőjét (= a cipőfüzőjét).

A másik esetben a forrástartomány a céltartomány altartománya (source-in-target metonymy, forrás-a-célban metonímia):

Szükségünk van néhány segítő kézre (= segítő emberre).

\subsubsection{A metonímia mint kiemelés: Klaus-Uwe Panther és Linda L. Thornburg metonímiaértelmezése}

Mint láthattuk, a fogalmi metonímia a fogalmi metaforához hasonlóan valamilyen célfogalomhoz biztosít hozzáférést. Az a hagyományos megközelítés, mely szerint a metonímia esetében egy dolog egy másik helyett áll (helyettesítéselmélet), túlságosan szük keretnek bizonyult, és sok kritikát kapott a kognitív nyelvészeti elemzésekben. Az újabb megközelítések a metonímiát olyan jelenségként kezelték, amely referenciapontként értelmezhető. A kritikák ellenére a kognitív nyelvészetben is intézményesült és a leírásokban is megjelenik az X Y HELYETT, X Y HELYÉN leírás a metonímia jellemzésekor, de - mint arra a kiskapitális betủtípus használata is utal - a metonímia ezekben az esetekben inkább tágabb fogalmakra vonatkozik, mintsem egy-egy fogalom denotátumára (Panther-Thornburg 2003: 2-3).

A metonímiában megjelenő tartományok közötti távolság mértéke a megértésre, a feladó által közölt tartalmak befogadásának és interpretálásának fokára és gyorsaságára van hatással. Az emberi elme fogalmi kapcsolatokat konstruál ok-okozati helyzetek, lehetséges és aktuális események, gyártók és termékeik, részek és egészek vagy egy egész részegységei között (Panther-Thornburg 2006: 185; Kocsány 2008b: 413). A kapcsolat a két entitás között igen változó távolságú lehet (Panther-Thornburg 2003: 3; 2006: 186):

A zongora [A ZONGORISTA] rosszkedvü.

A pénztárcám elvesztése [A PÉNZTÁRCÁM NEM BIRTOKLÁSA] rosszkedvűvé tett.

A (12)-es példamondat esetében nem biztos, csak lehetséges kapcsolat áll fenn a hangszer és a rajta játszó személy között, hiszen egy zongora jelenléte nem feltétlenül implikálja azt, hogy a zenész is jelen van a zongora által megnyitott fogalmi tartományban; ezzel szemben a (13)-as példamondatban a pénztárca elvesztése és nem birtoklása egymással ok-okozati kapcsolatban kell, hogy legyen.

Panther-Thornburg megközelítésében a metonímia referenciapont-jelenségként való szemlélésénél még tovább megy, és a célfogalom konceptuális kiemeléseként definiálja (Panther-Thornburg 2004: 106). A fenti példákból is látszik, hogy a metonímia a cél- 


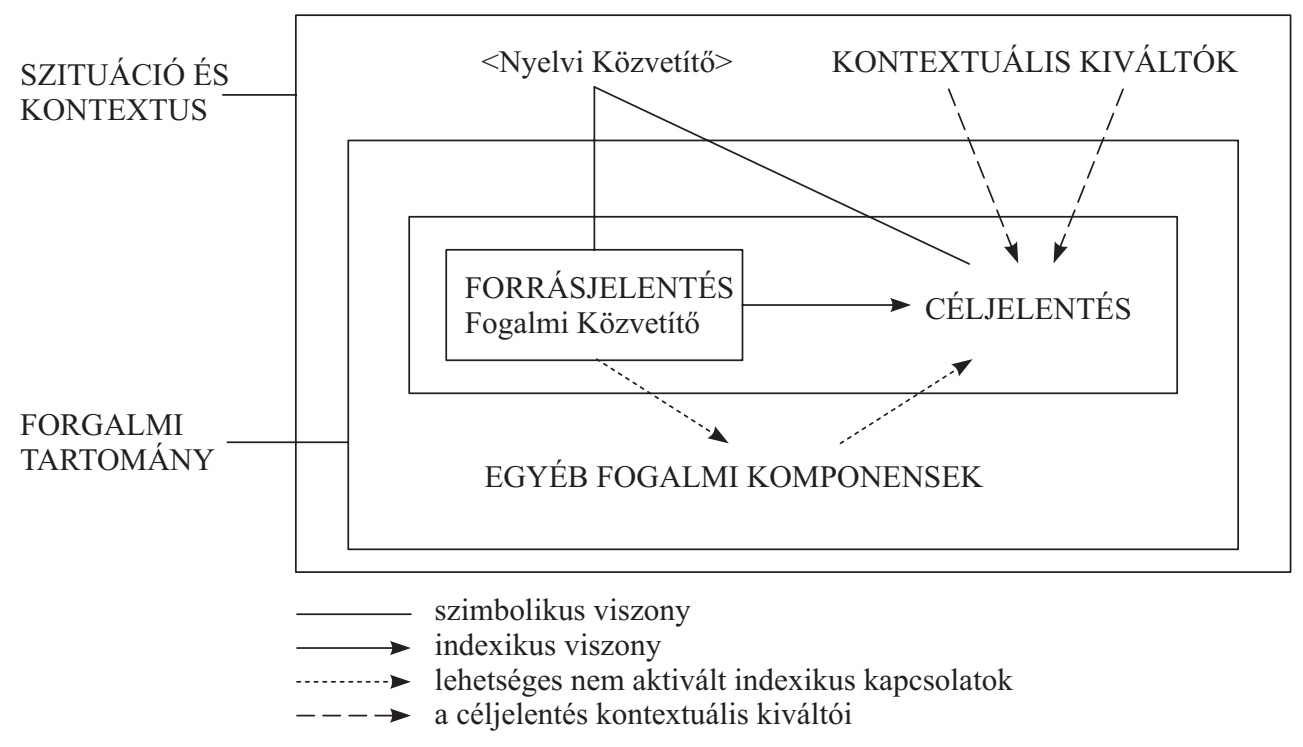

2. ábra: A metonímia általános, sematikus felépítése

fogalomnak valamilyen, az adott kommunikációs szituációban kiemelendő, releváns tulajdonságát képes megvilágítani vagy előtérbe helyezni (Panther-Thornburg 2003: 5) annak érdekében, hogy a befogadó (a hallgató, az olvasó) könnyebben megértse a célfogalmat.

Mivel a neologizmusok esetében az alakulatnak a befogadóval történő megértetése, sőt sok esetben a frappáns, egyedi vagy humoros jelentésszerkezete kifejezetten fontos, a 4. fejezetben bemutatott példák metonimikus jelentésviszonyait a Panther-Thornburg által megfogalmazott elvek (kiemelés, előtérbe helyezés, egy-egy releváns aspektus megvilágítása) alapján elemzem. Az elemzendő neologizmusokban fellelhető metonimikus jelentésviszonyok további jellemzői, altípusai természetesen nem állnak ellentétben azokkal a jellemzőkkel sem, amelyeket e fejezetben fentebb ismertettem (így például különbözö IKM-ek lelhetőek fel bennük, vagy jelentésszerkezetük elhelyezhető egy tágabb tartománymátrixban is).

A metonímia általános, sematikus felépítésének Panther-Thornburg-féle ábrázolását a 2. ábra mutatja be (Panther-Thornburg 2004: 96; 2006: 185 alapján).

A metonimikus folyamatok döntő fontosságúak a szemantikai változás és a grammatikalizáció területén (Panther-Thornburg 2007: 236); a metonímia megjelenésének köszönhetően kialakuló poliszémia elősegíti a legkülönfélébb jelentések konvencionalizálódását is, miközben dinamikus jelentésképzést tesz lehetővé (Panther-Thornburg 2003: 7).

Panther-Thornburg a következőkben összegzi a fogalmi metonímia legfontosabb ismérveit (Panther-Thornburg 2003: 7): 
1. A fogalmi metonímia olyan kognitív müvelet, amelyben a forrástartalom hozzáférést biztosít egy céltartalomhoz ugyanazon a kognitív tartományon belül.

2. A forrástartalom és a céltartalom viszonya véletlenszerü, fogalmilag nem szükségszerü, elvben vitatható.

3. A metonímia céltartalma előtérbe kerül (kiemelődik), míg forrástartalma háttérbe kerül.

4. A metonímia változatos funkciókat tölthet be a beszédaktusokban: referenciális, predikatív, propozicionális és illokúciós szinten is müködik.

5. A metonimikus kapcsolat erőssége forrás és cél között változó lehet, többek között azon múlik, hogy mekkora a konceptuális távolság a forrás és a cél között.

6. A metonímia fogalmi jelenség, mely áthidalja szemantika és pragmatika hagyományos megkülönböztetését.

A metonímiának a fent részletezett keretben történő megközelítésében PantherThornburg kiemeli: „a metonímia létének értelme az, hogy ne csak (...) hozzáférhetővé tegye a cél(jelentés)t, hanem - ami legalább ilyen fontos - hogy biztosítsa a rendelkezésre állását a bekövetkező diskurzusban" (Panther-Thornburg 2004: 107).

\subsection{5. Összegzés}

A fentiekben a metonímia megközelítési lehetőségeit mutattam be, különös tekintettel a kognitív nyelvészeti szakirodalomban fellelhetö értelmezésekre.

Adott kommunikációs szituációban a beszélőnek különböző céljai lehetnek egy-egy neologizmus használatával: a jelenség minél pontosabb megnevezése, hozzáférhetővé tétele a befogadó számára, továbbá eredetiségre, különlegességre törekvés is szerepelhet a céljai között. A közlés csak akkor ér célt, ha a befogadó képes interpretálni a hallott/ olvasott alakulatot; abban a mentális folyamatban pedig, mely ilyenkor a befogadó elméjében végbemegy, a metonímia az egyik olyan jelenség, mely alapvetően fontos szerepet játszik. Mindezek alapján elmondható, hogy a mai magyar nyelv neologizmusainak szemantikai szerkezetében a metonimikus jelentésviszonyok fontos szerepet töltenek be. A kontextus mint támogató mátrix fontossága, a referenciapont-szerkezet tulajdonságai, a tartományok közötti távolság és a kiemelés mind ezt a befogadási és értelmezési folyamatot segítik.

\subsection{A metafora}

\subsubsection{Bevezetés}

A köznyelvben nagy számban megjelenő új szavakat és kifejezéseket, azok későbbi „életét" vizsgálva felmerül a kérdés: miért érezhető az egyik neologizmus találóbbnak, sok esetben képszerübbnek, frappánsabbnak egy másiknál, és miért gyökeresedik meg emiatt a köznyelvben, míg egy másik eltünik? Mindebben feltehetően nagy szerepet játszik a 
megjelenő szó vagy kifejezés szemantikai felépítése. A mai magyar nyelvben megjelenő neologizmusok közül igen soknál megfigyelhető, hogy metaforikus jelentésszerkezetük van - ez hatással lehet „életképességükre”, későbbi fennmaradásukra is.

Mint azt Bencze Lóránt megjegyzi: az alapmüveknek számító arisztotelészi munkák (Poétika, Retorika) óta a metaforával foglalkozó szakirodalmak száma „mintegy exponenciálisan növekszik" (Bencze 1996: 268), így a szerteágazó kutatásokat szinte lehetetlen áttekinteni. Az Alakzatlexikon „Metafora” szócikke is felhívja a figyelmet a vonatkozó szakirodalom nagy mennyiségére és szerteágazóságára: „A metafora egyfelöl szépsége és sokszínüsége, másfelől a nyelv, a gondolkodás és a megismerés szempontjából meghatározó fontossága miatt az összes trópus és alakzat közül a legtöbbet vizsgált jelenség. Shibles metaforabibliográfiája 1971-ből 414 lapon sorolja a metaforáról szóló könyvek és tanulmányok címét, Noppen, De Knop és Jongen, illetve Noppen és Holms két újabb, vaskos bibliográfiája az 1970 és 1990 között megjelent publikációkkal folytatja a sort, és a kutatás láza azóta sem csökkent. Ennek okait magában rejti már Arisztotelész metaforafogalma; és mindazok a kérdések, amelyek belöle kiolvashatók, folyamatos állásfoglalásra késztetik a kutatókat” (Kocsány 2008a: 390).

A jelen fejezetben először röviden összefoglalom a metaforával, a metaforizációval kapcsolatos megközelítéseket elsősorban a stilisztikatörténet nézőpontjából, kiemelve a vizsgált téma szempontjából leginkább releváns megállapításokat. Majd az elmúlt harminc év kutatásait, eredményeit és a kognitív metaforaértelmezést mutatom be részletesen.

\subsubsection{A metafora meghatározásai, megközelítései az ókorban és a középkorban}

Arisztotelész Poétika címú munkájában (Arisztotelész 2004) a 21. fejezetben a metaforát a következőképpen definiálja: „Metafora a szó más jelentésre való áttétele, mégpedig vagy a nemről a fajra, vagy a fajról a nemre, vagy a fajról a fajra, vagy pedig analógia alapján" (Arisztotelész 2004: 56 - 1457b). Arisztotelész a metaforát tehát a jelentés áttételeként (átvitelként), helyettesítésként definiálja. A 20. századi stilisztikák a fenti jelenségeket a metonímia (és a szinekdoché) tárgykörébe sorolják. Az Alakzatlexikon vonatkozó szócikke is kiemeli: az arisztotelészi felosztásban szereplö típusok esetében „csak a két utolsó esetben beszélünk metaforáról (az első kettőben például ma már metonímiáról van szó)" (Kocsány 2008a: 390-391). Megvizsgálva Arisztotelész Rétorika címủ munkáját (i. e. 329-323), melyet időrendben a Poétika után írt, észrevehető, hogy itt a metafora jelenségét nem annyira a korábbi helyettesítéselméletnek, hanem inkább a hasonlításelméletnek megfelelően tárgyalja: „Mihelyt kiejtjük a metaforát, a hasonlóságnak tüstént nyilvánvalónak kell lennie" (Arisztotelész 1999: 143). A III. könyv elején a helyes szóhasználatról értekezve fontos és gyakran idézett megállapítása, hogy a metaforákat igen sokszor alkalmazzák az emberek: „prózastílusban (...) mindenki csak ezeket alkalmazza; ugyanis mindenki metaforákkal, alapjelentésủ és közhasználatú szavakkal társalog" (Arisztotelész 1999: 142).

Cornificius retorikai tárgyú művének ( $A$ C. Herenniusnak ajánlott retorika, i. e. 80-as évek) negyedik könyvében Arisztotelészhez hasonlóan a névátvitel müveletéből indul 
ki, s a metafora hasonlításként jelenik meg leírásában: „Metafora esetén egy dolog nevét átvisszük egy másikra, mivel az átvitel a két dolog hasonlósága miatt jogosnak tünik" (Cornificius 2001: 107). A metafora alkalmazásának célja véleménye szerint a szemléletesség, a tömörítés, a nagyítás vagy kicsinyítés, az obszcenitás elkerülése vagy egyszerüen a díszítés lehet (Cornificius 2001: 107).

Cicero szónoklattani munkái közül a De oratore (A szónokról, i. e. 55) és a De partitione oratoria (A beszéd részeiről, i. e. 46 körül) is tárgyalja a metaforák, a metaforikus nyelvhasználat szerepét a szónoki beszédben. Előbbi müben a translatio mint eszköz jelenik meg a beszéd szóhasználatának tárgyalásakor: eszerint a metafora széles körü elterjedtsége annak köszönhető, hogy természetes szükségletet elégít ki, mert a fogalmakat definiálnunk kell valahogyan; a metafora erre kiválóan alkalmas, hiszen elfogadható és szellemes (Cicero 1968: 123; 2012: 424-425).

Quintilianus Szónoklattan címü munkájában (i. sz. 94-95 körül) a metaforával kezdi a szóképek tárgyalását, hiszen „messze a leggyakoribb és messze a legszebb” (Quintilianus 2008: 547) szókép ez, melyet ő is névátvitelnek nevez. Arisztotelészhez hasonlóan rámutat, hogy a metaforahasználat korántsem kötődik pusztán a művészi nyelvhasználathoz: „Használata annyira természetes, hogy tanulatlanul is önkéntelenül gyakran élünk vele, ugyanakkor annyira kellemes és fényes, hogy bármilyen ragyogó szövegből úgyszólván saját fényével kivillan" (Quintilianus 2008: 547). Bencze összefoglalásában kiemeli, hogy a metaforának Quintilianus is elsősorban díszítő funkcióját hangsúlyozza, de hozzáteszi: „Védelmére annyit kell mondanunk, hogy ő azért még ismerte a metafora felfedező, ismeretközlő, pusztán »jelentésbeli« funkcióját is, nemcsak a díszítőt, csak hát az utókor évszázadokon át ezeket a sorait nem vette figyelembe..." (Bencze 1996: 270).

A fenti rövid áttekintésből látható, hogy az ókorban a metaforát elsősorban a szónok feladataival, a szónoki beszéd elkészítésével kapcsolatban, annak fázisai közül is az elocutión belül tárgyalták. Nem emelték még ki a metafora, a metaforikus nyelvhasználat hétköznapi megjelenését; a retorikai munkák szerzői elsősorban a szónoki és a szépirodalmi eszközök között tartották számon, és leggyakrabban hasonlóságként, átvitelként, esetenként helyettesítésként definiálták.

A középkorban a retorikaírók az ókori szerzők műveire is támaszkodtak, ugyanakkor a Szentírás magyarázata, a Biblia figuráinak és trópusainak elemzése is fontos cél volt. Philipp Melanchton (1497-1560) A retorika alapelemeinek két könyve címú munkájában Az utánzásról írt részben felhívja rá a figyelmet, hogy a „megszokás ellenére összekapcsolt” szavaktól óvakodni kell, és hozzáteszi: „ugyanígy kell vélekedni a metaforákról, melyek feltünést keltő újdonsága a beszédet is homályossá teszi. Amiként fentebb megmondtuk, mértékletességet kell tanúsítani ezen nem (genus) használatakor" (idézi Imre 2000: 76). A reformáció kora után az antik görög-római hagyomány új virágkorát élte, a katolikus egyházban a jezsuita rend járt élen a retorika oktatásában (Bitskey 2003: 7-8). Cyprianus Soarius (1524-1593) rendkívül sikeres, tankönyvként használt munkájában (Három könyv a retorika müvészetéröl) több fejezeten át részletesen tárgyalja a metafora forrásait, fajtáit. A metaforát, ,a szónoklatnak és a költészetnek is a legszebb ékességét” a következőképpen határozza meg: „Egy dolognak, szónak az áthelyezése a 
saját jelentésből egy másikba valamiféle hasonlóság alapján, amely az egymással öszszehasonlított dolgok közt kölcsönösen fennáll" (idézi Bitskey 2003: 59-60, kiemelések tölem - S. R.).

A fent tárgyalt szerzők metaforára vonatkozó megjegyzéseit olvasva megfigyelhető, hogy a kategóriák között sok olyan (pl. a mennyiség, a mozgás vagy az idő) is megjelenik, mely a későbbi metaforaelméletekben is visszaköszön, és az úgynevezett hétköznapi metaforák közül is igen soknak az alapját képezi. Mindezek ellenére ebben az időszakban elsősorban még mindig pusztán díszítőelemnek tartották nemcsak a metaforát, hanem a szóképeket általában, és nem foglalkoztak a mindennapi nyelvhasználatban betöltött szerepükkel.

\subsubsection{A metafora az újkori felfogásokban}

„A XX. századi leíró nyelvtanok és az általános nyelvészet, ha egyáltalán foglalkoztak a metaforával, megragadtak ott, ahol az időben jóval korábbi filozófusok tartottak" (Bencze 1996: 282). Jespersen és Sapir felfogásában a metafora vagy pusztán az ősi, primitív nyelvhasználathoz, vagy az előbbihez szorosan kötődő költői nyelvhez kapcsolódott, Bloomfield pedig egyenesen marginális jelenségnek és devianciának tartotta (Bencze 1996: 282). A liège-i retorika erősen strukturalista felosztása is leszükítette az elocutio területére a metaforaalkotást, így a középkori felfogásnál nem lépett tovább (Bencze 1996: 268).

Változás csak a 20. századi nyelvfilozófiai felfogásokban történt; ezek rámutattak arra, hogy a metafora a közönséges, hétköznapi nyelvhasználatnak is sajátja; a nyelvlélektani és etimologikus megközelítések (például Zlinszky Aladár, Gombocz Zoltán, majd Stephan Ullmann) a metafora eredetét, illetve az asszociációk szerepét emelték ki (Bencze 1996: 283). Richards már 1936-ban kimondta, hogy a metafora nem „deviatio”, anomália, hanem a nyelvi kompetencia szerves része (Richards 1950 [1936]: 190, idézi Bencze 1996: 284).

\subsubsection{Max Black a metaforáról}

Max Black 1962-ben megjelent Models and Metaphors címü munkájában részletesen vizsgálja a metaforát és a hozzá kapcsolódó jelenségeket. (Magyarul 1990-ben, a Helikon folyóiratban jelent meg a könyv egy részlete $A$ metafora címmel.) Black a könyv III. fejezetének kezdetén több olyan kérdést is felvet, amelynek tisztázása nélkülözhetetlen a metafora jelenségének vizsgálatakor. E kérdések a következők: „Hogyan ismerjük fel a metaforát?”, „Vannak-e olyan kritériumok, amelyek alapján felismerhetjük a metaforát?”, „Lefordíthatók-e a metaforák szó szerinti kifejezésekké?”, „Helyes-e, hogy a metaforát puszta dekorációnak tartjuk?”, „Milyen összefüggések vannak a metafora és a hasonlat között?”, „Milyen értelemben nevezhető a metafora »kreatív«-nak?”, „Mi a metafora használatának lényege?”, „Egyáltalán, mit nevezünk metaforának?” (Black 1962: 25). 
Black a metafora „tiszta” eseteit képviselö példamondatok segítségével kiemeli a metaforikus értelemben használt szavakat, kifejezéseket, majd értelmezésük során megállapítja: amikor egy viszonylag egyszerủ metaforáról beszélünk, akkor arra a mondatra vagy kifejezésre utalunk, amelyben bizonyos szavak metaforikus értelemben szerepelnek, míg a többi nem metaforikus értelemben van jelen. A szerző bevezeti a metafora fókusza és a keret fogalmát: előbbi az adott mondatban metaforikus értelemben használt szó, míg utóbbi a mondat többi része (Black 1962: 28). A felmerülő kérdés az, hogy miért lesz egy szó metafora egy bizonyos keretben, s miért nem lesz az, ha egy másik keretben használjuk? A válasz a két „keret” összehasonlításából származó különbségekből adódik; ráadásul sok olyan eset is van, amikor a metaforikus kifejezés jelentése a megnyilatkozó intencióiból fejthető meg - ezek a jelentésviszonyok inkább a pragmatika, mint a szemantika tárgykörébe tartoznak (Black 1962: 29-30).

Black ezek után a metafora vizsgálatának, megközelítésének három lehetséges elméletét (a metafora helyettesítéselméletét, hasonlításelméletét és interakció-elméletét) mutatja be (Black 1962: 34-39). Egy későbbi írásában (Black 1980) reflektál a fent részletezett írására, célként jelölve meg, hogy figyelmét bizonyos metaforák „kognitív aspektusaira" (Black 1980: 21) fordítsa.

A Max Black-i metaforamegközelítést azért fontos a jelen fejezetben kiemelni, mert a témának olyan új megközelítési lehetőségeit mutatta be, amelyeket a későbbi elméletek megalkotói is felhasználtak. Black megközelítésében a metafora és a metaforizálás folyamata aktív, a közlő és a befogadó szempontjait egyaránt figyelembe vevő folyamatként ábrázolódik; ráadásul azzal, hogy - a fent összefoglalt módon - több szempontú megközelítési lehetőségeket mutat be a szerző, lehetővé teszi a metafora jelenségének alaposabb vizsgálatát is.

Az 1970-es években zajló megközelítések a metaforakutatás terén több újdonságot is hoztak: legfontosabb ezek közül kiemelni a kognitív megközelítésnek azt az eredményét, mely a metaforát a nyelvben, müködése közben vizsgálta. Míg ugyanis más megközelítések hajlottak rá, hogy a metaforát kontextusából kiragadva, pusztán szótári vagy nyelvtanokból származó források alapján tárgyalják, addig a kognitív megközelítés rávilágított, hogy a metafora nem csupán járulékos, származtatott vagy éppen deviáns jelenség, hanem ,[i]nkább átható gondolkodásmód, az emberi kogníció és nyelv alapvető aspektusa, olyannyira, hogy a nyelv elképzelhetetlen nélküle" (Traugott-Dasher 2004: 75-76).

\subsubsection{Kiindulópont a kognitiv metaforaelmélethez: George Lakoff- Mark Johnson a , hétköznapi metaforákról"}

1980-ban jelent meg George Lakoff és Mark Johnson Metaphors we live by címü könyve; Kövecses ezt az elméletet nevezi a metafora „standard” elméletének (Kövecses 2009: 271). Lakoff és Johnson munkája „a legjobb kiindulópontként szolgálhat a metafora kognitív keretben történő tanulmányozásához" (Tolcsvai Nagy 2005a: 65). A szerzőpáros itt, majd Lakoff ezt követő írásaiban (pl. Lakoff 1987; 1990) rámutat: általános, „,normális" gondolkodásunk, fogalmi rendszerünk, tehát maga az emberi gondolkodás folyamata alapvetően metaforikus (Lakoff-Johnson 1980: 6, 56), vagyis a metafora 
olyan jelenség, mely nemcsak a nyelvhasználatot, hanem a hétköznapi életet is áthatja (Lakoff-Johnson 1980: 3).

Lakoff és Johnson megközelítése nevezhetö „a metafora kognitív nyelvészeti megközelítésé"-nek (Kövecses 2005a: 14), melyben a hagyományos metaforafelfogásokkal szemben a következőket fogalmazták meg: „(1) a metafora elsősorban a fogalmak, és nem a szavak jellemző tulajdonsága; (2) a metafora funkciója az, hogy segítse bizonyos fogalmak megértését, és nem csupán múvészi vagy esztétikai célokat szolgáljon; (3) a metafora gyakran nem hasonlóságon alapszik, (4) a metaforákat a köznapi emberek is a legkisebb erőfeszítés nélkül használják (...); (5) a metafora nem egy fölösleges, bár kellemes nyelvi díszítőeszköz, hanem az emberi gondolkodásnak és megértésnek elengedhetetlen kelléke" (idézi Kövecses 2005a: 14).

A szerzőpáros a fogalmi metaforáknak három nagy csoportját különíti el: az ontológiai, az orientációs és a strukturális metaforákat (Lakoff-Johnson 1980: 15-61). E felosztással kapcsolatban meg kell jegyezni, hogy valószínüleg e háromnál több típus is elkülöníthető, „kivált az igei metaforák között” (Tolcsvai Nagy 2010: 91).

\subsubsection{Fogalmi tartományok: forrástartomány, céltartomány}

Fogalmaink metaforikus módon rendszereződnek, ezért lehetséges, hogy egy fogalomhoz tartozó kifejezéseket egy másik fogalmi tartományhoz tartozó kifejezésekkel magyarázzunk (Lakoff-Johnson 1980: 52). A metafora tehát ebben az elméleti keretben két fogalmi tartomány közötti megfelelés, leképezés eredményeképpen jön létre.

A két tartomány közötti leképezés eredményeképpen létrejövő, úgynevezett fogalmi metaforák esetében az egyik tartományt a másik segítségével értelmezzük. Azt a tartományt, ahonnan a metaforikus kifejezéseket merítjük, forrástartománynak (source domain), azt az absztrakt tartományt pedig, amelynek fogalmait a forrástartomány segítségével értjük meg, céltartománynak (target domain) nevezzük (Lakoff-Johnson 1980: 52; Kövecses 1998: 53; 2005a: 20; Tolcsvai Nagy 2005a: 65; 2013: 211-212). A leképezés a forrás- és a céltartomány között mindig részleges (Tolcsvai Nagy 2005a: 65), maga a forrás- és a céltartomány egymástól független fogalmak, ,amelyek a megismerésben valamilyen motiváció révén kerülnek egymással kapcsolatba" (Tolcsvai Nagy 2010: 90). A fentiekből fakadó következményeket Lakoff-Johnson így fogalmazza meg: „Kijelenthetjük, hogy természetes fogalmi rendszerünk metaforikusan szervezett, vagyis legtöbb fogalmunkat más fogalmak kifejezéseinek segítségével, részlegesen értjük meg. Ez fontos kérdést vet fel fogalmi rendszerünk alapjaival kapcsolatban. Létezhetnek-e olyan fogalmak, amelyeket közvetlenül, metaforák nélkül megértünk? Ha nem, hogyan érthetünk meg egyáltalán bármit is?" (Lakoff-Johnson 1980: 56).

\subsubsection{A metaforaalkotás mint aktív folyamat}

E szerint az elmélet szerint tehát a metaforaalkotás aktív folyamat, amelyben a metaforák nem elszigetelt nyelvi kifejezések. A fogalmi metaforák tapasztalati alapúak (Tolcsvai Nagy 2005a: 66), ezért lehetséges, hogy számos fogalmi metafora és a hozzá kapcsolódó 
úgynevezett metaforikus kifejezések (a forrástartomány terminológiájából kikerülő kifejezések) univerzálisak, így különböző nyelvekben és kultúrákban igen hasonló módon jelennek meg (lásd Kövecses 2005b: 74-81 példáit).

Feltehetően fontos szerep jut a metaforikus viszonyok megalkotásában a kiemelésnek és az elrejtésnek, vagyis annak, hogy egy jelenségnek milyen jellemzőjét, aspektusát tartja adott szituációban kiemelendőnek az emberi elme - mindez távolabbról szoros kapcsolatban áll az előtér-háttér, figura-alap viszonyokkal is. A kiemelt aspektusok segítségével kifejezhetővé válnak olyan elvont fogalmak is, amelyek megértése, megértetése egyébként komoly mentális erőfeszítést igényelne (Lakoff-Johnson 1980: 10-13). Ezeknek az elveknek a jelenléte, valamint az, hogy egy új szónak vagy kifejezésnek a megalkotója kiknek a számára, milyen céllal alkotja meg a szót, nagymértékben érvényesül egy-egy neologizmus szemantikai szerkezetében.

A metaforikusság az új szavak, kifejezések létrejöttében gyors elérést biztosíthat a befogadóknak abban az esetben, ha az új jelenség jelentésének konstruálásában segítséget nyújt a metaforikus kiemelés. Ehhez járul még az, hogy abban az esetben, hogyha a metaforában a megfelelő aspektus emelődik ki, a jelentés sikeres „megfejtésével” a nyelvhasználók pozitív attitüdöt táplálnak majd az új alakulat iránt - ez pedig hozzájárulhat az elterjedéséhez, népszerüségéhez. A metaforák konvencionalizálódásának folyamatához kapcsolódik Lakoff és Johnson azon állítása, mely szerint a nyelvben nincsenek úgynevezett „holt metaforák”; ismert példájuk a következő mondat (Lakoff-Johnson 1980: 106):

\section{(14)}

Alátámasztotta az érvelést.

Felhívják a figyelmet arra, hogy két hagyományos felfogás, az absztrakció és a homonímiaelv értelmében a fenti nyelvi kifejezés nem számít metaforikusnak: az absztrakció értelmében azért nem, mert e szerint az elmélet szerint semmi köze nincs egymáshoz egy ÉPÜLET és egy ELMÉLET alátámasztásának. A homonímiaelv pedig vagy azt mondja ki, hogy két jelentés (ALÁTÁMASZT ${ }_{1}$ és ALÁTÁMASZT ${ }_{2}$ ) létezik, melyek teljesen különböznek egymástól (erőshomonímia-elv), vagy azt, hogy a két jelentés bizonyos tekintetben hasonló lehet, és a két fogalom ennek a hasonlóságnak köszönhetően kapcsolatban lehet egymással (gyengehomonímia-elv) (Lakoff-Johnson 1980: 106-107). Ezek a jelentések a metaforák hagyományos felfogása szerint olyan mértékben konvencionalizálódtak, hogy már senki nem tekinti öket metaforáknak (Kövecses 1998: 51). A kognitív metaforaelmélet értelmében azonban számos olyan kifejezés létezik (nemcsak az angol nyelvben), mely valamilyen módon kapcsolódik az ÉPÜLET fogalmához.

\subsubsection{Az invarianciaelv}

A forrástartomány-céltartomány viszonyt megvizsgálva, a fenti elmélettel kapcsolatban az alábbi probléma merült fel: „mi az az ismeret, amely a forrástartományból átkerül a céltartományba, és mi az, ami nem? (...) nyilvánvaló, hogy nem kerül át a forrástartománnyal kapcsolatos teljes tudásunk a céltartományba" (Kövecses 1998: 63). Mint azt 
Kövecses példája is mutatja, AZ OKOZÁS ÁTADÁs fogalmi metafora esetében a következö példában a pofon nem kerül át ahhoz a személyhez, akinek adták (Kövecses 1998: 63):

(15)

He gave me a kick. (Adott egy pofont.)

„A jelen példában [a] forrástartományból az átadást mint okozást felhasználták, de az átadott tárgy fennmaradásá[t] és a fogadó félnél maradásá[t] nem. De ha nem kerül át minden, mi az, ami átkerül, és mi az, ami nem?" (Kövecses 1998: 63). A probléma megoldását Lakoff és Turner dolgozták ki (pl. Lakoff 1990, idézi Kövecses 1998; Tolcsvai Nagy 2005a) az úgynevezett invarianciaelvben. Ennek lényege a következöképpen foglalható össze: „A metaforikus megfelelések esetében örizzük meg a céltartomány sematikus (image-schematic) struktúráját és vigyünk át a forrástartomány sematikus struktúrájából mindent a céltartományba, ami nem ellentétes a céltartomány struktúrájával" (Kövecses 1998: 64). Így például AZ ÉLET UTAZÁs fogalmi metaforához kapcsolódó következő példában

Úgy élte le az életét, hogy nem hagyott nyomot.

a forrástartományából az UTAZÓ, illetve a NYOM feleltethető meg a céltartományban az életet élő személy életének, a halála után pedig maga után hagyottaknak (Kövecses 1998: 64).

\subsubsection{Lakoff „,kiterjesztett metaforaelmélete”}

Az 1980-ban írt Metaphors we live by címü munkája után Lakoff 2008-ban írt tanulmányában a metafora jelenségét neurális alapokon vizsgálja; ez a megközelítés nevezhető „Lakoff kiterjesztett metaforaelméleté”-nek (Kövecses 2009: 274). Ennek az elméletnek nagy előnye, hogy - a „standard” metaforaelmélettel szemben, mely néha meglehetősen statikus viszonyt feltételez a metafora vagy metaforikus kifejezés forrás- és céltartománya között - a kiterjesztett vizsgálat „lehetőséget ad rendkívül általános metaforák feltételezésére is" (Kövecses 2009: 274). Az elmélet lényegének értelmében a fogalmak metaforikus értelmezése során az agyban két különböző neuroncsoport, a forrás- és a céltartomány neuroncsoportja egy időben aktiválódik.

A „kiterjesztett metaforaelmélet” vagy - a lakoffi elnevezéssel élve - neurális elmélet alkalmazásának hasznát Lakoff a következőképpen foglalja össze: ennek az elméletnek a segítségével jobban megérthetjük a nyelv erejét egy metaforában: minden szó egy keret elemeként értelmezhető, és mint ilyen, szemantikai szerepet tölt be. Ha egy ilyen keret elemeit aktiváljuk, azok magát az egész keretet (gestaltot) is képesek aktiválni; egy ilyen keret pedig több olyan sémát is tartalmazhat, melyben újabb keretek találhatók, és képesek aktiválódni. Ezeknek a kereteknek mindegyikét fogalmi metaforák strukturálják, tehát egy-egy elem aktiválásakor az egész metaforarendszer aktiválódhat. Bizonyos kontextusokban pedig az aktivált struktúrák még egymásra is hathatnak (Lakoff 2008: 34). 
Lakoff megközelítésének lényege az, hogy a metafora létrejötte és a metaforarendszerek esetleges kialakulása ebben a keretben dinamikusan, megkonstruálásuk közben vizsgálhatók. Tény azonban, hogy azon túl, hogy ily módon igen általános metaforákkal dolgozik, azok szervező (és alkotó) egységeiként ugyanúgy a forrás- és a céltartomány fogalmait használja, mint a korábbi, Lakoff-Johnson-féle elmélet.

\subsubsection{A metafora mint kategorizációs aktus: Sam Glucksberg - Boaz Keysar elmélete}

A Sam Glucksberg - Boaz Keysar szerzőpáros megalkotta metaforaelméletben a metafora mint „kategorizációs aktus” szerepel (Kövecses 2009: 271). 1993-as tanulmányukban Glucksberg és Keysar felidézik azokat a pragmatikai elveket, amelyek értelmében a befogadó képes a szó szerinti jelentést és a közlő által sugallt jelentést megkülönböztetni. Searle-t idézve alkalmazzák a fenti elveket a metaforára: „Ha a mondat értelme talányos, keress egy beszélői jelentést, mely különbözik a mondatjelentéstöl" (idézi GlucksbergKeysar 1993: 402). Az elmélet értelmében a metafora létrehozásának folyamata során „egy entitást egy kategóriához rendelünk hozzá, amely kategóriát egy másik ugyanebbe a kategóriába tartozó entitás példáz vagy képvisel” (Kövecses 2009: 271).

Glucksberg egy későbbi írásában (Glucksberg 2008) három általános elvvel és példák sorával mutatja be a metaforák gyors interpretálásának lehetőségét. Kiindulásul felveti: bizonyosak lehetünk-e abban, hogy egy metafora (vagy metaforikus kifejezés) megértése a hasonlításelv segítségével gyorsabban lehetséges, mint magának a (nem szó szerinti jelentést hordozó) metaforának a megértése? Három, a hasonlításelmélettel kapcsolatos implikációt - 1. a szó szerinti jelentéseket mindig elsőként és feltétel nélkül dolgozzuk fel, 2. a hasonlatokat mindig könnyen megértjük, legyen szó szó szerinti vagy átvitt értelmü jelentésröl, 3. a metaforák hasonlatokká alakíthatók, tehát ha $X$ egy $Y$, akkor $X$ olyan, mint $Y$ - cáfol. Így igazolja, hogy 1. a metaforák megértése nem opcionális, hanem kötelező jellegü, ezért automatikus, 2. a metaforákat általában nem hasonlattá átalakítva, hanem feltünésük pillanatában, önálló kijelentésként értjük meg, 3. a metaforák és a hasonlatok nem cserélhetők fel, hiszen jelentésük sok esetben kisebb-nagyobb különbségeket hordoz (Glucksberg 2008: 68-69). A fenti cáfolatok példájaként említi Glucksberg az újszerü metaforákat, amelyek ,ugyanolyan gyorsan megérthetők, mint a hasonlóságon alapuló nyelvi kifejezések, feltéve, hogy az újszerủ metaforák találók" (Glucksberg 2008: 69).

Visszatérve a metafora „kategorizációs aktus” elméletéhez, Glucksberg a kategorizáció aktusát a következőképpen vonja be a metaforák vizsgálatába: a metaforák sok esetben értelmezhetők ugyan hasonlatként, ám ez nem mindig lehetséges. Vannak viszont olyan esetek, amikor a metafora megértése kizárólag kategorizációs folyamatként zajlik, míg máskor a metafora hasonlatként (vagy még pontosabban: hasonlításként) értelmezhető. Az említett tanulmány példaként a következő mondatot hozza (Glucksberg 2008: 79):

(17)

Úgy éreztem magam, mint egy szardínia. 
A fenti kijelentés elhangzásakor a beszélő valószínűleg nem arra céloz, hogy úgy érezte magát, mintha - méretét, szagát vagy ehetöségét tekintve - szardinia lenne, hanem a „szardíniaság”-nak egy meglehetősen speciális esetét, aspektusát (ti. a zsúfolt helyen való bezártságot) tapasztalta meg (Glucksberg 2008: 79-80). Ebben az elméleti keretben tehát a metafora megértésében fontos szerepe van a kategorizálás folyamatának, melynek során a közlő (és a befogadó is) a metaforajelentés egy bizonyos aspektusának segítségével interpretálja a metaforát.

Ennek az aspektusnak a „megtalálása”, „,megfejtése” a metaforikus jelentésszerkezetü neologizmusok esetében nagyon fontos. A „megfejtés” sebessége, sikeressége, tehát a jelentés elérésének útvonala és annak jellemzői nagymértékben befolyásolhatják a neologizmus elterjedését, fennmaradását a nyelvhasználók közösségében. A Glucksberg által említett aspektus megtalálását jelentősen elősegítheti a metaforában vagy a metaforikus kifejezésben megjelenő, már Lakoff-Johnson által is említett kiemelés.

A fent említett aspektus, mely Glucksberg esetében a metafora jelentésének konstruálásában segítséget nyújtó nézőpontot jelenti, sok esetben metonimikus alapú kell, hogy legyen: a metafora megértéséhez a jelentés konstruálásakor bizonyos, az adott metaforára és a metaforát tartalmazó szituációra vonatkozó viszonyokat vehet figyelembe a metafora használója. E viszonyok alapulhatnak ok-okozat, tulajdonos-tulajdonság, idö, hely stb. metonimikus relációkon, és segítséget nyújtanak abban, hogy adott szituációban milyen aspektust érdemes figyelembe venni annak érdekében, hogy a metafora relevánsan múködjön a kommunikációban, vagyis a befogadók - a metafora használójának szándékától függően - találónak, szellemesnek, emlékezetesnek érezzék.

\subsubsection{A metafora Kövecses Zoltán-féle, jelentésfókuszon alapuló elmélete}

A Kövecses Zoltán által képviselt metaforamegközelítés a Lakoff-féle „standard” fogalmi metaforaelméleten alapul, annak egy változataként értelmezhető: „A fogalmi metaforának tehát van egy jelentésfókusza, egy fő témája, ha úgy tetszik. Mi határozza meg egy adott forrás- és céltartomány viszonyának jelentésfókuszát? Úgy vélem, hogy minden forrástartomány egy sajátos szerepet játszik az általa jellemzett céltartományok konceptualizálásában” (Kövecses 2005a: 119). E szerint az elmélet szerint „,egy forrástartománnyal társított jelentésfókusz automatikusan, vagyis elmebeli erőfeszítés nélkül, leképeződik a céltartományra” (Kövecses 2009: 274), a céltartomány pedig „megörökli a forrástartomány jelentésfókuszát" (Kövecses 2005a: 120). Ezzel a megközelítésmóddal - mely pszicholingvisztikai tapasztalatokon alapul - meg lehet magyarázni olyan bonyolult fogalmi metaforák gyors mentális feldolgozását is, amelyeket a hagyományos elmélet nehézkesen tudott leírni. Kövecses példája a következő jól ismert példához kapcsolódik:

Ez a sebész egy hentes. 
A fenti mondatban szereplö metafora megértéséhez az elme gyors müködése következtében nem kell pontról pontra értelmeznie a befogadónak a SEBÉsz és a HENTES fogalmakhoz kapcsolódó jelentésfókuszokat, mivel azok automatikusan leképeződnek a forrástartományról a céltartományra (Kövecses 2009: 274). Ebben az elméleti keretben a forrás- és a céltartomány közötti kapcsolatot lehetővé tevő fogalmi mechanizmusok vizsgálatakor a kategória mint egész és annak jellemzője (Kövecses 2009 példájában a „hentes” és az „elnagyolt, durva munkavégzés”) között metonimikus kapcsolat áll fenn. „Ezzel a változattal kiküszöbölhető a standard metaforaelmélet problémája, nevezetesen az, hogy nem tudjuk megmagyarázni, hogy miért visszük át vagy rá, az »elnagyolt, durva munkát végző« (és vele a »kontárság«) jellemzőt a hentesről a sebészre" (Kövecses 2009: 274). Ez az elméleti keret tehát lehetőséget ad a két tartomány viszonyának vizsgálatára is, és a metonimikus viszony segítségével történő értelmezés segít(het) megmagyarázni forrás- és céltartománynak az invarianciaelvben kifejtett viszonyát is. A Glucksberg-Keysar által megfogalmazott elmélethez képest ez a megközelítés többet mond az „ugyanabba a kategóriába tartozás”-ról is: az egymástól leggyakrabban jelentős mértékben távol álló fogalmak (pl. sebész-hentes) lehetséges kapcsolódási pontjaira enged következtetni az entitások és tulajdonságaik metonimikus kapcsolatba hozásával.

A fenti relációk érzékeltetésére vezeti be Kövecses a részleges metaforikus hasznosítás, a metaforikus kiemelés, illetve az elrejtés mozzanatát a fogalmi metaforák vizsgálatában. A forrás- és a céltartomány vizsgálatában fontos - és a már említett metonimikus megfeleléssel is korreláló - megállapítása, hogy fogalmi metaforák létrehozásakor a forrástartománynak nem az összes, hanem csak bizonyos részeit használjuk fel (Kövecses 2005a: 91-95). Az előzö jelenségből következik, hogy amiatt, hogy a forrástartománynak csak bizonyos elemeit használjuk fel a leképezéskor, a fogalmi metaforában lesznek olyan aspektusok, amelyek kiemelödnek, míg mások rejtve maradnak.

Szintén a kommunikációs szituáció függvényében dől el, hogy egy kívánt céltartomány konceptualizálására hány forrástartományt használunk fel: a kommunikációs helyzet és a részt vevő partnerek igényétől függően több vagy kevesebb forrástartományra lehet szükség annak érdekében, hogy a céltartomány bizonyos aspektusait kifejezzék (Kövecses 2005: 96-102, és erre utal Kövecses-Benczes 2010: 86-88 is). A forrástartományok száma, valamint a lehetséges kiemelések jelenléte fontos lehet egy-egy új szó vagy kifejezés megalkotásában, illetve befogadásában; szerepet játszhat továbbá a neologizmus meggyökeresedésében vagy eltünésében is.

\subsubsection{A Lakoff-Johnson-féle „standard” metaforaelmélet kritikája: Joseph Grady alapmetafora-elmélete}

Joseph Grady a Lakoff-Johnson-féle elméletet vizsgálva több írásában (pl. Grady 1997; 1998) felteszi a kérdést: miért kell bizonyos, szerkezetükből adódóan problémákat felvető metaforákat komplex metaforaként számon tartani? A korábbi elmélet kritikájaként rámutat: az ilyen típusú fogalmi metaforákat az elemzők hajlamosak úgy kezelni, mintha a kommunikációban részt vevő felek egyszerủen előre csomagolt üzeneteket küldenének egymásnak (Grady 1998: 205). 
Grady megközelítése szerint a fó problémát a Lakoff-Johnson által megalkotott elmélet metaforáival kapcsolatban az jelenti, hogy bizonyos metaforák esetében a metafora (vagy a metaforikus kifejezés) létrejöttekor a leképezés nem valósul meg száz százalékban a forrástartományból a céltartományra. Grady kritikájában kiemeli, hogy Lakoff-Johnson 1980-as munkájában egy adott metafora „kihasználatlan elemei”, vagyis azok az aspektusok, amelyek nem képeződtek le a forrástartományból a céltartományba, nem voltak megjósolhatók. A másik probléma véleménye szerint az volt, hogy a „standard” metaforaelmélet leírásában úgy tünhetett, hogy a „kihasználatlan elemek” (,lyukak”), melyek az adott fogalmi metaforában nem képeződtek le, kevésbé világosak vagy érthetőek a nyelvhasználók számára, és ritkábban használatosak, mint azok, amelyek megjelentek a céltartományban (Grady 1997: 280).

Grady szerint az általa javasolt megközelítésmódnak több előnye is van. Javaslata a feltárt hiányosság miatt a következő: AZ ELMÉLETEK ÉPÜLETEK metafora például inkább tekinthető egy sokkal általánosabb metafora, AZ ELMÉLETEK FIZIKAI STRUKTÚRÁK metafora példájának; ebben a fogalmi metaforában a „fizikai struktúrák” lehetnek épületek, textíliák („Darabokra tépték az elméletet”), műalkotások („Elméletük a logikai alkotás mestermüve") stb. (Grady 1997: 272). A lakoffi metaforaelmélet kritikájaként felveti, hogy a fenti esetben inkább AZ ABSZTRAKT SZERKEZET FIZIKAI SZERKEZET vagy A SZERVEZET FIZIKAI SZERKEZET fogalmi metaforákat lenne célszerü használni. Ezek a fogalmi metaforák, amelyeket Grady ,alapmetaforá”-nak (primary metaphors) nevez, sokkal általánosabbak, mint a Lakoff-Johnson által javasoltak, így lehetőséget adnak az eddig „,nem besorolható" esetek tágabb keretben történő értelmezésére is.

Grady megközelítésének nagy előnye, hogy olyan fogalmi metaforákat, amelyeknek forrástartománya azonos (pl. AZ ELMÉLETEK ÉPÜLETEK és AZ ELMÉLETEK TEXTÍLIÁK) nem kell külön metaforaként kezelni ebben a keretben, hanem közös jelentéstartalmuk alapján lehetséges egy magasabb szintü fogalmi metaforaként (A SZERVEZETEK FIZIKAI SZERKEZETEK) tekinteni rájuk, hozzátéve, hogy e fogalmi metaforák a bennük megvalósuló elaboráció módjában különböznek. „Azzal, hogy megmutatjuk, hogy ezek a területek két, tapasztalati alapon összefüggő kognitív kapcsolat révén rokonai egymásnak, fontos általánosítást teszünk" (Grady 1997: 287).

A metaforában megjelenő leképezés dinamikussá tételében fontos meglátása Gradynek, hogy célszerủ az adott jelenséget (esetünkben a metaforát) a kommunikációs helyzetben vizsgálni. A metaforikus jelentésviszonyok ilyen dinamikus kialakulásában megragadott szemlélete a metaforikus szemantikai szerkezetet mutató neologizmusok vizsgálata során is hasznosnak bizonyulhat, hiszen ugyanaz az új szó vagy kifejezés a nyelvhasználat során a kommunikációs szituációtól függően más-más kontextusban tünhet fel (így erre a típusú elemzésre adnak jó lehetőséget például az internetes fórumszövegek).

\subsection{4. Összegzés}

A jelen fejezet célja a metaforával és a metaforikus nyelvhasználattal kapcsolatos, a kutatás elméleti keretével összefüggésbe hozható megközelítések bemutatása volt. 
A 4. fejezet szemantikai elemzései a kognitív metaforaértelmezést veszik alapul: építenek a Lakoff-Johnson által megalapozott metaforaelméletre; az ennek az elméletnek a kiegészítéseiként, továbbfejlesztéseiként megjelent elgondolásokból pedig azokat a megközelítéseket tekintik irányadónak és alkalmazzák, amelyek a befogadót a neologizmus megértéséhez hozzásegítik. Ilyenek a figyelem irányításának a metaforikus szemantikai szerkezetben megjelenő lehetőségei: a forrástartomány és a céltartomány viszonya, a kiemelés, a jelentéskonstruálás szempontjából releváns aspektusok hangsúlyozása. Ezeknek a viszonyoknak a müködöképessége döntheti el, hogy megtörténik-e a neologizmus megértése, mely az új jelenség használatának, megmaradásának alapvető feltétele.

\subsection{A fogalmi integráció (blend)}

\subsubsection{A mentális terek és a fogalmi integrációs elmélet bemutatásának célja}

A jelen fejezet a mentális terek elméletét és a fogalmi integráció azon alapuló modelljét mutatja be. Célja elsősorban az, hogy rámutasson a modell gyakorlati alkalmazási lehetőségeire (különös tekintettel a neologizmusok szemantikai szerkezetének elemzésében való jelentőségére). Ez azért is fontos, mert általában véve elmondható a magyar nyelvben megjelenő neologizmusokról (és így a 4. fejezetben elemzendő neologizmusokról is), hogy sok olyan található közöttük, amely szemantikai felépítésének a fogalmi integrációs elmélet keretében való elemzése igen gyümölcsöző lehet. Ezek a neologizmusok felépítésüket tekintve változatosak: akadnak közöttük összetett szavak (például kutyaszitter), szó- és toldalékcsonkok összekapcsolásából létrejött alakulatok (például csokoholista), valamint igekötős igék is (például betámad).

\subsubsection{A mentális tér}

1985-ben jelent meg Gilles Fauconnier munkája az úgynevezett mentális terekről (Fauconnier 1994 [1985]). Az itt olvasható megfogalmazás alapján a mentális terek „kis fogalmi egységek, melyeket a gondolkodás és a beszéd során hozunk létre a szituációbeli megértés és cselekvés céljából" (Fauconnier-Turner 1998b: 137). A mentális terek valamely adott forgatókönyv entitásainak és viszonyainak részleges reprezentációi, melyeket a beszélő valamilyen módon megért (Coulson-Oakley 2000: 176-177).

Fauconnier említett munkájában hangsúlyozza az indentifikáció alapelvének (ID Principle), más néven a hozzáférési alapelvnek (Access Principle, Fauconnier 2007: 353) a fontosságát, melynek értelmében a nyelvhasználók különböző szemantikai szerkezetủ kapcsolatok azonosítására képesek. Kiemeli a Nunberg által bevezetett pragmatikai funkció fontosságát a mentális terek kialakulásának folyamatában, hiszen a mentális tereket a gondolkodás és a beszéd folyamata során alakítjuk ki az aktuális megértés és megnyilatkozások céljainak megfelelően (Fauconnier 2007: 351). A fent leírt modell a kommunikációs szituációnak megfelelöen változhat, és általános váza a 3. ábrán látha- 
tó módon ábrázolható (Fauconnier 1994 [1985]: 5; Sweetser 1996: 320; Tolcsvai Nagy 2010: 97; 2013: 107).

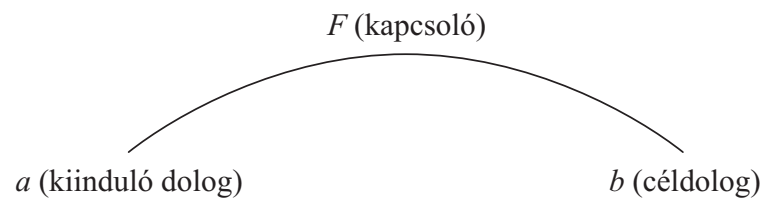

3. ábra: A modell általános váza

Mint azt a 3. ábra általános jellege is mutatja, a mentális terekre nagyfokú rugalmasság és széles körủ felhasználhatóság jellemző, kialakulásuk ugyanakkor nem esetleges: a pragmatikai kapcsolók, a szövegben megjelenő nyelvi kifejezések biztosítják a kapcsolatot a különböző terek között (Tolcsvai Nagy 2010: 98). Ezeket a nyelvi elemeket (például prepozíciókra utaló kifejezéseket, határozószókat, kötőszókat), melyek bármilyen diskurzusban iránymutatóként szolgálnak, térépítőknek nevezzük (Fauconnier 1994 [1985]: 16).

A mentális terek olyan egységek, amelyeket ,sok különböző célnak megfelelően sokféleképpen aktiválhatunk" (Fauconnier 2007: 351), és egymással különféle leképezések segítségével kapcsolódhatnak össze. A terek forrásai igen változatosak lehetnek: a mentális terek a diskurzus kibontakozásának folyamatában dinamikusan épülnek ki a munkamemóriában, tulajdonságaik pedig sok, egymástól egyébként elkülönülő tartomány jellemzőjéből származhatnak. Az emberi gondolkodásból, a kulturális jellemzőkből és a kommunikáció jellemzőiből fakad, hogy a mentális terek elsáncolódhatnak a hosszú távú memóriában is, így könnyítve meg a hozzáférést; ilyen elsáncolódott terekre példa a „Jézus a kereszten”, amely a „keresztre feszítés”, a „gyermek Jézus” vagy a „Jézus, Isten fia" és sok, e mentális térhez kapcsolódó asszociációt nyit meg. Ezekben az esetekben egy mentális tér elemei és relációi elözetes tudásként értelmezhető „csomag”-ként szerveződve, keretként jelennek meg (Fauconnier 2007: 352), melyeket tipikusan bizonyos diskurzustípusok esetén dolgozunk ki (Sweetser-Fauconnier 1996: 11).

A mentális terek változatos konfigurációkban kapcsolódhatnak össze a nyelvhasználók elözetes tudása és a Lakoff által idealizált kognitív modelleknek nevezett tudásszervező rendszereknek köszönhetően. Az így kialakuló mentális szerveződések sok esetben nem a valóságot tükrözik: gyakran az egyén hiedelmeivel, előzetes tudásával kapcsolatosak.

\subsubsection{A fogalmi integráció}

A fent bemutatott mentális terek összekapcsolódása számtalan különböző módon valósulhat meg a gyakorlatban, a kommunikáció folyamatában részt vevő nyelvhasználók előzetes tudásától, a müködésbe lépő tudáskeretektől, a kommunikációs partnerek elvárásától, értelmezésétől függően. 
Az úgynevezett fogalmi integráció elmélete Gilles Fauconnier és Mark Turner nevéhez köthető: „A fogalmi integráció, melyet blendingnek ['elegyítés, vegyítés'] is nevezünk, alapvető mentális folyamat, mely mentális terekkel dolgozik" (Turner 2007: 378). A szerzőpáros 1998-as írásaiban (Fauconnier-Turner 1998a; 1998b; 1998c; 1998d) rámutatott, hogy számtalan olyan müvelet (például a keretek, az analogikus leképezések vagy a referenciapont) létezik, melyet nyelvi és nem nyelvi szituációban egyaránt felhasználunk a megértés folyamatában. A fogalmi integráció folyamatának eredményeképpen létrejövő blendet több mentális tér építi fel.

\subsubsection{A blendben megjelenő terek}

Az integráció során a leképezésben két bemeneti tér (input space) található, melyek között leképezés (cross-space mapping) valósul meg (Fauconnier-Turner 2002: 40-41). A terek közötti leképezésre jellemzö, hogy részleges, és a két bemeneti tér megfelelö jellemzői között valósul meg (Fauconnier-Turner 1998a: 269).

A harmadik megjelenő tér a generikus tér (generic space), mely a két bemeneti tér jellemzőit képezi le egymásra (Fauconnier-Turner 2002: 41). „A generikus tér valamilyen általános, általában absztraktabb, a két bemeneti tér által közösen birtokolt szerkezetre és szerveződésre reflektál, és meghatározza a bemeneti terek közötti leképezés lényegét" (Fauconnier-Turner 1998a: 270). A generikus térben megjelenő absztrakt leképezés mutatja be az emberi elmében lejátszódó összetett folyamatokat, amelyek segítségével a megértés lezajlik. A generikus tér esetében még az egyazon időben és térben való létezés sem feltétele a sikeres blend létrejöttének: időben igen távol eső jelenségeket is összekapcsolhatunk. Erre példa Fauconnier-Turnernél két hajó, az 1853-ban a San Francisco-Boston távot megtevő Northern Light és az 1993-ban ugyanezt a távot teljesítő Great America II versenye, amelyben a két hajó teljesítménye a blendben úgy válhat összehasonlíthatóvá, hogy időben és térben egymás mellé helyeződnek (Fauconnier-Turner 1998a: 272-273; 1998b: 154-156).

A negyedik megjelenő tér az integrált tér vagy más néven az elegyítés tere, a blend (blended space), melyben a két bemeneti tér részleges kivetítése megjelenik (Fauconnier-Turner 1998a: 270; 2002: 41-42). Fontos hangsúlyozni, hogy a blendben szelektív kivetítés következtében jelennek meg a bemeneti terekből származó viszonyok, jellemzők (Turner 2007: 378).

A generikus tér és az integrált tér között keletkezésükböl fakadóan összefüggések mutathatók ki: ,,a blendek tartalmaznak a generikus térben megragadott generikus szerkezetet, de specifikusabb szerkezetet is, és tartalmazhatnak olyan szerkezetet is, amely a bemenetek számára kizárt" (Fauconnier-Turner 1998b: 143).

A két bemeneti térből, valamint a generikus térből és az integrált térből létrejövő blend általános, sematikus ábrázolása a fentieknek megfelelően a 4. ábrán látható módon alakul (Fauconnier-Turner 1998a: 272 alapján).

A 4. ábrán látható, hogy a bemeneti terekben megjelenő jellemzőknek nem mindegyike vetítődik ki a generikus térbe; vannak tehát olyan tulajdonságok, melyeket nem 


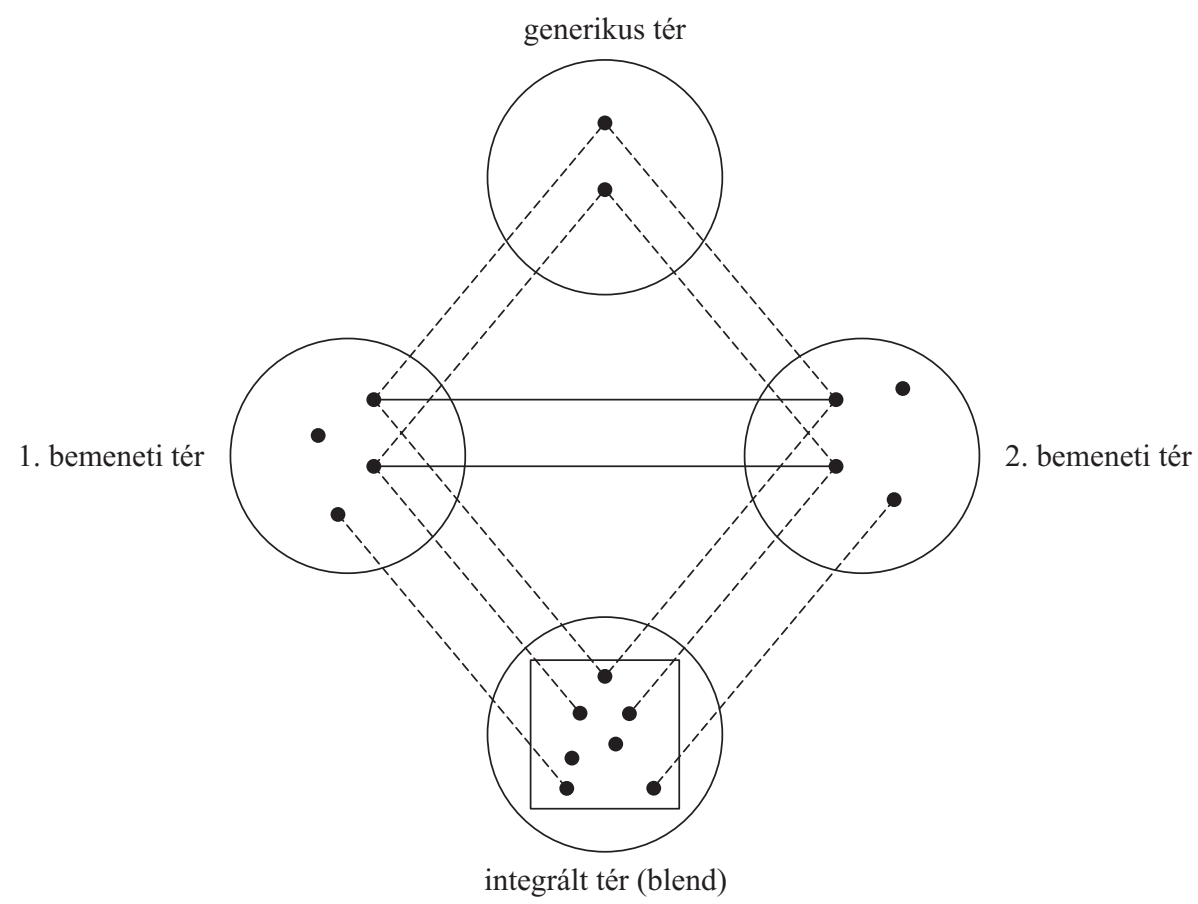

4. ábra: A fogalmi integráció folyamatának általános, sematikus ábrázolása

használunk fel a blend létrehozásában. Másfelöl az is látható, hogy a blendben megjelenhetnek olyan jellemzők is, amelyek külön-külön jellemzőek csak az egyes bemeneti terekre, és esetleg nincs is közös, egymásnak megfeleltethetö pont közöttük. A létrejövő szerkezet dinamikáját és a blendnek a szövegkörnyezethez, az aktuális szituációhoz való rugalmas ,igazíthatóságát” éppen ezek a jellemzők adják.

A bemeneti terekben megjelenő tulajdonságok a nyelvhasználók előzetes tudásának, lehetséges asszociációinak tekintetében is erősen viszonylagosak, változékonyak lehetnek, és - mint azt a jelen témához kapcsolódó kérdőíves felmérések válaszai is mutatják - nagymértékben befolyásolhatják egy-egy jelenség, például egy-egy neologizmus értelmezésének folyamatát.

\subsubsection{A blend létrehozásában szerepet játszó múveletek}

Ahhoz, hogy a blendben létrejövő, folyamatos asszociációkra lehetőséget adó és a szerkezet „futtathatóságát” biztosító emergens szerkezet létrejöhessen, a blend konstruálásában három folyamat kap fontos szerepet (Fauconnier-Turner 1998b: 144; Coulson-Oakley 2000: 180-181; Benczes 2006: 53):

1. Összetétel: az integráció folyamata olyan elemeket társít, amelyek a bemeneti terekből származnak, de a különálló bemeneti terekben nem szerepelnek. 
2. Kiegészítés: a blendben létrejövő jelentésben megjelenhet a befogadónak olyan háttértudása is, amelyet a blend létrejöttekor tudatosan nem is észlel, mindössze kiegészíti vele a létrejövő szerkezetet.

3. Kidolgozás: a blend kialakulásának elvei és logikája alapján különböző mentális folyamatok vezethetnek el a szerkezet elaborációjához; a blendek különböző mértékben lehetnek kidolgozva, akár igen nagy mértékben is.

\subsubsection{Optimalitási feltételek}

Ahhoz, hogy a blend létrejöhessen, bizonyos alapelveknek, úgynevezett optimalitási feltételeknek (optimality principles) kell teljesülniük. „Egy fogalmi integrációs hálózatot dinamikusan hozunk létre egy időintervallumon belül, mely nagyon rövid (mint egy vicc megértése), de nagyon hosszú is lehet (mint egy új tudományos fogalom, például a komplex számok fogalmának emergenciája évszázadokon keresztül). Ahhoz, hogy a folyamat sikeres legyen, sok feltételnek kell teljesülnie. A hálózatban megjelenő tereket bizonyos vonatkozásban önállóan is kell tudni müködtetni, míg más vonatkozásaik a hálózat fennmaradó részeihez kapcsolódnak. Az új kivetítések kidolgozás révén valósulnak meg. Az újonnan létrejövő térnek, a blendnek meg kell öriznie a saját integrált emergens szerkezetét, ugyanakkor a bemeneti terekre is vissza kell vetítenie a releváns információkat" (Fauconnier-Turner 1998a: 280).

A fenti elvek alapján a blend létrejöttének öt optimalitási feltétele különíthető el (Fauconnier-Turner 1998a: 280; Tolcsvai Nagy 2010: 101; 2013: 230), bár gyakran nem mindegyikük elégíti ki teljes mértékben a blend követelményeit (Oakley 1998: 343):

1. Integráció: a blendnek jól integrált jelenetet kell leképeznie, mely egységként kezelhetö.

2. Topológia: bármely elemek közti viszonynak, mely a bemeneti terekben szerepel, és megjelenik a blendben, meg kell felelnie a blend elemei közötti viszonynak.

3. Háló: ahhoz, hogy a blendet egységként tudjuk kezelni, megfelelő kapcsolatoknak kell lenniük a blend és a bemeneti terek között.

4. Kicsomagolás: a blendnek minden külső segítség nélkül alkalmasnak kell lennie rá, hogy a befogadó „kicsomagolja”, megértse a létrejövő szerkezetet a bemeneti terek, a terek közti leképezések, a generikus tér és az összes, a blendben szerepet játszó tér közti kapcsolathálózat rekonstruálása során.

5. Jó ok: ha egy elem megjelenik a blendben, annak jelentősége kell, hogy legyen, mely jelentőség releváns kapcsolatokat tartalmazhat más, a blend müködtetése során szerepet játszó terekkel és funkciókkal.

Az optimalitási feltételekkel kapcsolatban Coulson-Oakley megjegyzi, hogy e feltételeknek való megfelelés szelektív: ha egy blend megfelel egy feltételnek a fentiek közül, gyakran inkonzisztens egy másiknak való megfelelés tekintetében, bár tény, hogy egy adott blend adott interpretációi közül az a leginkább elfogadott, amely legjobban megfelel az optimalitási feltételeknek (Coulson-Oakley 2000: 186). 


\subsubsection{A fogalmi integrációs hálózatok (blendek) típusai}

Az eddigiekben bemutatott fogalmi integrációs lehetőségek sokfajta hálózat kialakulását segíthetik elő; a lehetőségek egyik lényeges dimenziója az, hogy a hálózat terei milyen mértékben tartalmaznak speciális kereteket. A másik kapcsolódó lényeges dimenzió annak mértéke, hogy az egyes bemeneti terek külön-külön milyen lehetőséget adnak a blendben megjelenő keretek számára. Ezek a dimenziók kontinuumot alkotnak, melyben néhány prototipikus esetet emelhetünk ki. „A különböző típusú fogalmi integrációkat egy skálán helyezhetjük el, attól függően, hogy milyen kognitív folyamatok vesznek részt a blend kialakulásában. (...) A két véglet között pedig számos átmenet létezik" (Kövecses-Benczes 2010: 179). A fogalmi integrációnak Fauconnier-Turner három, Kövecses-Benczes négy alapvető, jól elkülöníthető típusát különbözteti meg. Előbbieknél ezek a kerethálózatok, az egyoldalú és a kétoldalú hálózatok (Fauconnier-Turner 1998a: 276), míg utóbbiak a szimplex, a tükör-, az egyoldalú és a kétoldalú hálózatok típusait különítik el (Benczes 2006: 54-57; Kövecses-Benczes 2010: 179-187).

\subsubsection{A fogalmi integráció elméletének továbbfejlesztése: Ruiz de Mendoza Ibáñez modellje}

A blendingelméletnek létezik egy úgynevezett kiterjesztett változata is, melyet Ruiz de Mendoza fogalmazott meg (1996; 1998, idézi Ruiz de Mendoza - Peña 2005: 252). Ruiz de Mendoza - Peña 2005-ös írásukban a Ruiz de Mendoza - Díez-féle (Ruiz de Mendoza - Díez 2002, idézi Ruiz de Mendoza - Peña 2005: 252) kombinált bemeneti hipotézis (combined input hypothesis) elvét javasolják az integrációs folyamat bizonyos típusainak megjelenítésére.

Ennek a megközelítésnek az értelmében a blend létrejöttében szerepet játszanak olyan bemeneti terek is (a szerzőpáros ,,a kivetítés terei”-nek nevezi őket, Ruiz de Mendoza Peña 2005: 257), melyek nem feltétlenül találhatók meg a kommunikációban aktuálisan szereplő terekben. Az említett terek a nyelvhasználó korábbi, már létező tapasztalataira, emlékeire támaszkodva jelennek meg, és aktivizálódhatnak a jelentéskonstruálási folyamat során (Ruiz de Mendoza - Peña 2005: 252).

Az elméletben szereplő lehetséges bemeneti terek és integrált terek viszonya, a terek (és az általuk megnyitott lehetőségek) száma a Fauconnier-Turner-féle modelléhez képest tehát megsokszorozódhat; ezt a lehetőséget a szerzők az 5. ábrán látható általános modellel szemléltetik (Ruiz de Mendoza - Peña 2005: 256 alapján).

Az 5. ábrán látható, hogy a kombinált bemeneti terek több forrástartomány kivetítéséből keletkeznek, a bemeneti terekben megjelenő entitások pedig egymással megfelelési vagy ellentétes viszonyban is lehetnek. Ezek kivetítéséből jönnek létre azok az implikációk, amelyek a kivetítés terében megjelennek.

A fenti modell a Fauconnier-Turner-féle modellhez képest nagyobb mértékben számol a nyelvhasználók korábbi tapasztalataiból, előzetes tudásából származó ismereteivel is mind a bemeneti terek, mind pedig az integrált terek kialakulása során. Ez a jellemző 


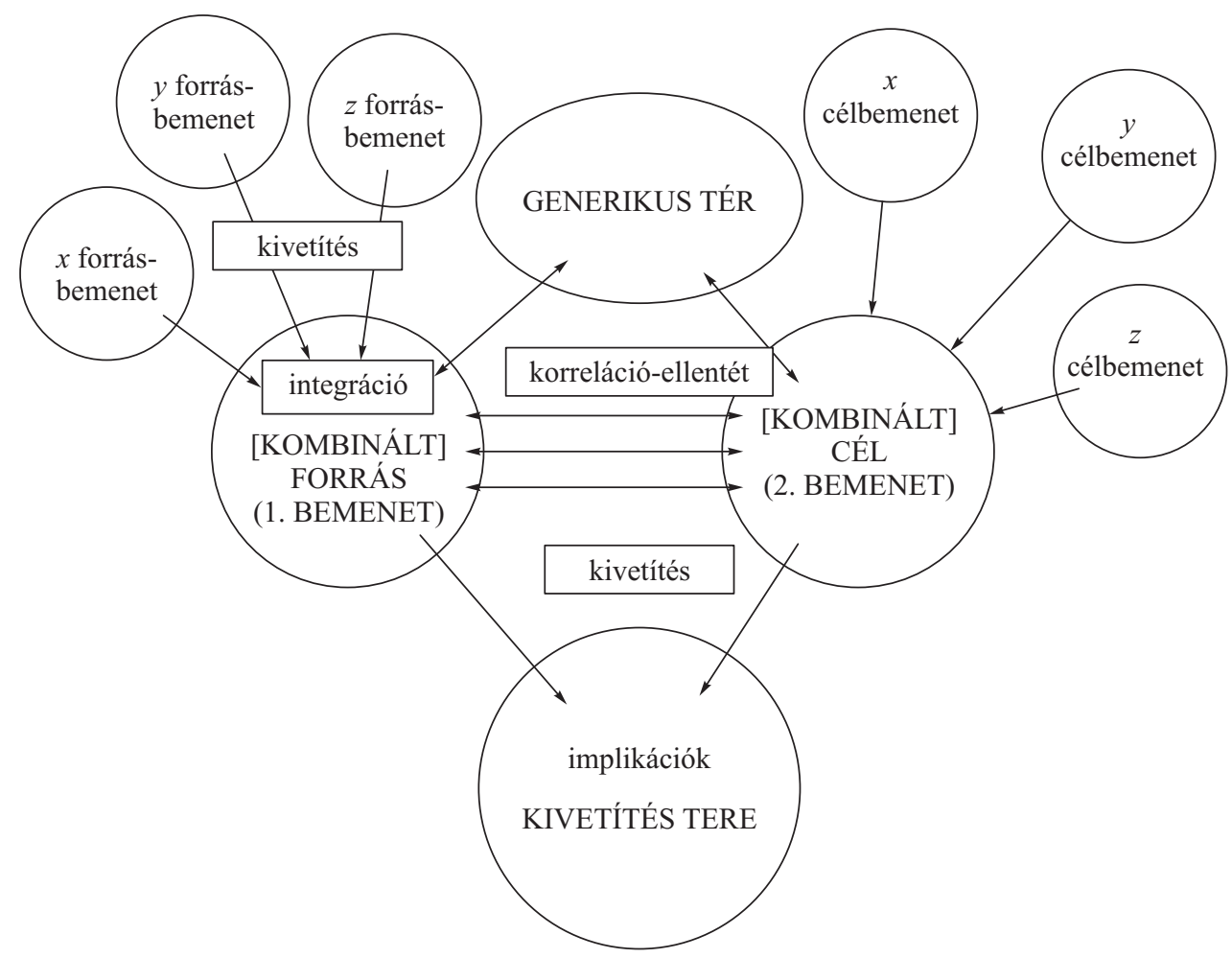

5. ábra: A kombinált bemeneti hipotézis általános modellje

pedig kapcsolatba hozható a már korábban említett jóváhagyó struktúra (Tolcsvai Nagy 2001a: 48) szerepével, és nagymértékben befolyásolhatja a befogadó értelmezési stratégiáit a jelentéskonstruálás folyamatában.

Ruiz de Mendoza - Peña a fent idézett írásukban viszont egyértelműen utalnak arra, hogy az általuk vázolt modell a Fauconnier-Turner-féléhez képest kevésbé dinamikus, tehát a blend kialakulása közben már nem számolnak olyan mértékủ emergens szerkezet kibontakozásával, mint a „klasszikus” fogalmi integrációs elmélet. A megsokszorozódó bemeneti terek részben ennek a rögzítettségnek a következtében jönnek létre; másrészröl viszont tény, hogy a Ruiz de Mendoza - Peña 2005 által vázolt bemeneti terek száma és jellege nyelvhasználófüggő volta miatt egyénenként változhat, és igen nagy eltéréseket is mutathat ugyanannak a blendnek az értelmezési folyamatában is.

\subsubsection{Blend és metonímia, blend és metafora}

A fogalmi integráció során létrejövő leképezések természete igen dinamikus, ez pedig mind a blendben megjelenő metonimikus, mind a metaforikus jelentésviszonyokra igaz. 
A blend és a metafora viszonyának (vö. Grady-Oakley-Coulson 1999) tekintetében elmondható, hogy míg a Lakoff-Johnson-féle fogalmi metaforák „fogalmi tartományokat képeznek le egymásra meglehetösen magas absztrakciós szinten" (Fauconnier-Turner 1998a: 279), addig a blendek szerepe „online” jellegükből fakadóan az, hogy alapvető fogalmi motivációt biztosítsanak a bemeneti terek összehangolásához és így a terek közötti leképezéshez. A metonímia szerepét pedig a fogalmi integráció folyamatában Fauconnier és Turner is többször hangsúlyozza (Coulson-Oakley 2003: 51).

A fentiek értelmében elmondható, hogy metaforikus és metonimikus jelentésviszonyok egyaránt megjelenhetnek a fogalmi integráció folyamata során, ráadásul különböző arányban, és a jelentés létrehozása során különböző logikai kapcsolatban vesznek részt a kommunikációs folyamatban. Ruiz de Mendoza - Peña a metonimikus és metaforikus kiterjesztést is felmutató blendek esetében a jelentéskonstruálás folyamatának négy altípusát (metaforikus forrásbemenet metonimikus kiterjesztése, metaforikus forrásbemenet metonimikus leszükítése, metaforikus célbemenet metonimikus kiterjesztése és metaforikus célbemenet metonimikus leszükítése) különbözteti meg (Ruiz de Mendoza - Peña 2005: 268-269).

\subsubsection{0. Összegzés}

A jelen fejezet célja a 4. fejezetben található neologizmuselemzések elméleti megalapozásához való hozzájárulás volt; ennek értelmében az elemzéseket tartalmazó fejezet a fogalmi integráció elméletének segítségével elemzi tizennégy, az elmúlt években a magyar nyelvben megjelent neologizmus szemantikai szerkezetét. 


\section{ELEMZÉSEK}

\subsection{Az elemzések célja}

A jelen fejezet olyan neologizmusok szemantikai szerkezetének bemutatására vállalkozik, amelyek az elmúlt években jelentek meg a magyar nyelvben. Az elemzésre kiválasztott neologizmusok grammatikai szerkezetüket tekintve különbözőek, jellemző módon több összetett szó és igekötős ige található köztük, kiválasztásuk oka ugyanakkor nem grammatikai, hanem szemantikai felépítésük volt. Az elemzésekhez szerves módon kapcsolódnak az elmúlt években (2006 és 2011 között) négy korcsoportba sorolható adatközlőkkel, összesen 1072 fövel felvett kérdőíves vizsgálódásaim eredményei is, melyek minden alkalommal néhány kiválasztott neologizmus ismertségével, megértésével, és így tágabb értelemben szemantikai szerkezetével kapcsolatban szolgáltattak adatokat (vö. Sólyom 2009a; 2009b; 2010a; 2011, majd 2012a; 2012b; 2012c; 2013). A kérdöíves felmérések közül a jelen fejezet elemzéseiben a 2008-ban, 2009-ben, 2010-ben és 2011-ben felvetteket idézem.

\subsection{Az elemzések módszertana. Az elemzendő szemantikai jellemzők}

A kiválasztott neologizmusok elemzése a következőképpen alakul: először közlöm a vizsgálandó szónak a kikövetkeztethető jelentését vagy saját megfogalmazásban, vagy olyan internetes forrásokból, melyek az adott jelenséggel foglalkoznak, és azt ott definiálják. Ezután az elemzendő szavakat környezetükben, internetes fórumszövegekben mutatom be, ily módon lehetővé válik a szó jelentésének és használatának tanulmányozása is a beszélő-hallgató viszonyában. Majd a szemantikai szerkezet elemzésével részletesen bemutatom a szó lehetséges jelentését vagy jelentéseit, valamint a kérdőíves felmérésekből származó vonatkozó eredményeket.

A vizsgálandó neologizmusok szemantikai szerkezetének elemzésével kapcsolatban különös jelentősége lehet a korábbi fejezetekben már bemutatott, az emberi gondolkodásban alapvető fontosságú jelentésszervező folyamatoknak. Ezeket a folyamatokat: a metonimikus, metaforikus jelentésviszonyok múködését, illetve a fogalmi integrációs modellt a vizsgált szavak szemantikai elemzésében a korábbi fejezetekben ismertetett elméletek, megközelítési lehetőségek közül azokra támaszkodva használom fel, amelyek az elmúlt időszakban a kognitív nyelvészeti vizsgálódások alapjául szolgáltak. Így 
a metonimikusság jelenségét elsősorban mint referenciapont-szerkezetet (Langacker 1993) és mint kiemelést (Panther-Thornburg 2003; 2006; 2007) értelmezem. A metaforikusság esetében a fogalmi metaforák és az úgynevezett idealizált kognitív modellek (IKM-ek) elméletére (Lakoff-Johnson 1980; Kövecses 2005a; 2005b), illetve a metafora kategorizációs aktusként való értelmezésére (Glucksberg-Keysar 1993) támaszkodom. A fogalmi integráció folyamatát az elemzendő neologizmusokban a „klasszikus” modell (Fauconnier-Turner 1998a; 1998b; 2002), valamint Benczes munkái (2006; 2010) alapján alkalmazom, és ennek az elméletnek a segítségével ábrázolom grafikus formában az elemzett neologizmusok szemantikai szerkezetét.

\subsection{A kérdőíves felmérésekről}

A jelen fejezetben következő szemantikai elemzések szempontjából fontos bemutatni azoknak a kérdőíves vizsgálódásoknak a jellemzőit és felvételük módszerét, amelyeket az elmúlt években a neologizmusokkal kapcsolatban végeztem.

Kérdőíves felméréseket 2006-tól kezdve 2012 elejéig hétszer, összesen 1072 adatközlö részvételével végeztem. Egy-egy felmérés alkalmával mindig négy korcsoportba sorolható adatközlők töltötték ki a kérdőíveket. A négy korcsoport a következőképpen alakult: felső tagozatos általános iskolások, 10-12. osztályos középiskolások, egyetemi hallgatók és felnőttek. A felnőttek csoportját olyan alap-, közép- és felsőfokú végzettségü, 25-65 év közötti adatközlők képviselték, akik már nem folytattak tanulmányokat, vagy - ha felsőfokú végzettségúek voltak - első diplomájukat már megszerezték. A kérdőíveket Budapesten, illetve a Dunántúlon töltötték ki az adatközlők.

Az elemzésekhez felhasznált kérdőíveknek két típusát használtam: az „A” típusban szövegkörnyezet nélkül, a „B” típusban pedig internetről származó mondatokban olvashatták kiemelve a megadott neologizmusokat. A kérdések a jelentéskonstruálás folyamatára igyekeztek rávilágítani: a kérdőív kitöltőinek arra kellett válaszolniuk, hogy szerintük mit jelentenek a megadott szavak vagy kifejezések, illetve milyen rokon értelmü szavakkal vagy körülírással adnák meg a jelentését a neologizmusnak abban az esetben, ha szerintük van jobb, találóbb szó vagy leírás, mellyel helyettesíthető lenne a neológ alakulat. A kérdőívek rákérdeztek arra is, hogy általában mi a véleménye az adatközlőknek a megadott szavakról, kifejezésekről (volt-e a felsoroltak között olyan, amely kifejezetten tetszett, vagy kifejezetten nem tetszett nekik, és ha igen, miért).

A jelen fejezetben szemantikai elemzésbe ágyazva a kérdôíves vizsgálatok releváns eredményeit fogom idézni, a felmérések eredményeinek bemutatásakor azonban hangsúlyozni kell, hogy mivel a jelentéskonstruálás folyamata általánosságban véve közvetlenül nem vizsgálható nyelvészeti módszerekkel, mind a következőkben vázolandó szemantikai elemzések, mind pedig a kérdőíves vizsgálódások vonatkozó eredményei csupán arra alkalmasak, hogy modelláljanak bizonyos mentális folyamatokat. 


\subsection{A jelen fejezetben közölt esettanulmányok bemutatásának okai, indokoltsága}

A következőkben az elemzés céljából kiválasztott neologizmusok részletes szemantikai elemzését közlöm. Az egyes esettanulmányok bemutatásának sorrendje az elemzendő szavak, kifejezések grammatikai felépítéséből fakad. Először két olyan szónak (csokoholista, tanorexiás) az elemzését mutatom be, mely - elsősorban az angol nyelvben is meglévő megfelelöi mintájára - grammatikai szempontból szócsonkokból létrejött összetételt alkot. Bemutatom, hogy két, szerkezeti felépítése tekintetében igen hasonló szó, az úgynevezett morfológiai blendek vagy szóösszerántások (Kövecses-Benczes 2010: 191) csoportjába sorolható példa esetében miért zökkenőmentes a jelentéskonstruálás az egyik szónál (csokoholista), és miért ütközik akadályokba a másik (tanorexiás) esetében.

E két eset bemutatása után olyan, az elmúlt években keletkezett neologizmusok szemantikai elemzését közlöm, amelyek két tőszó összetételéből állnak. Kissé átmeneti eseteket képvisel az a két -szitter utótagú szó (kutyaszitter, dédiszitter), melyeknél az egyik összetételi tag a magyar nyelvben önállóan még nem gyakran használt, ám az angolban már elterjedtebb szitter (sitter).

A következő esettanulmányok hat összetett szóval foglalkoznak. Az elemzések sorrendjének oka a következő: először olyan szavak felépítését vizsgálom, melyek tükörfordítással keletkeztek valamilyen más (angol vagy német) nyelvből. Ezeknek a szavaknak (gerillakertész, kanapészörf, passzivház, zöldbünözés) az esetében az elemzések bemutatják, hogy a magyar nyelvben hogyan alakul a szavak szemantikai felépítése, értelmezhetősége, illetve kimutathatóak-e a kommunikációban való használatukkor abból fakadó különbségek, hogy az őket alkotó tagok jelentése a magyar nyelvben esetleg nem teljesen ugyanazt jelenti, mint a forrásnyelvben.

Ezután két olyan összetett szó szemantikai szerkezetét elemzem, amely a magyar nyelvben keletkezett (bagolyvonat, kormányablak). A kérdőíves vizsgálat eredményei is alátámasztják, hogy az e két szó jelentésének megértésében tapasztalható különbségek szemantikai szerkezetük felépítésére vezethetők vissza.

Majd két, a napjainkban nagyon elterjedt $e$ - elötaggal keletkezett alakulat (e-könyv, e-könyv olvasó) elemzése következik. Utóbbival kapcsolatban bemutatom a jelentéskonstruálás folyamatában megjelenő akadályokat is, amelyeket a 2011-es kérdőíves vizsgálatban tapasztaltam.

Az utolsó részt a napjainkban gyakran hallható, olvasható be igekötős igék közül a betámad és a becéloz szemantikai elemzése alkotja. Az elemzés megalapozásául röviden áttekintem a be igekötő és a be igekötős neologizmusok történetét, majd - ismét az elmúlt évek kérdőíves felméréseinek eredményeire támaszkodva - megpróbálom modellálni azokat a mentális folyamatokat, amelyek miatt a nyelvhasználók napjainkban gyakran érzik adekvátnak ezeknek az alakulatoknak a használatát. 


\subsection{Az elemzendő neologizmusok részletes vizsgálata}

\subsubsection{1. esettanulmány: csokoholista}

A(19)-es számú szövegrészletben a két fórumozó egy „,csokoholista klub”-ból kilépő tagról beszélget. Ebben a párbeszédben jelenik meg a csokoholista ('a csokoládé fogyasztását túlzásba vivő, mániákus csokoládéevő személy’) szó (kiemelések tőlem - S. R.).

Törölt felhasználó 2007. 05. 15.21:45:40

nike nekem nem tetszik, hogy cseszegetsz;) Pedig én nem adtam rá okot. Én csak tippet adtam Neked. Hát ezt érdemlem onee-chan?;)

Tényleg kéne tartani egy csokoholista gyülést, s másik javaslat. Goczi aljas módon a csokievő avatárját lecserélte (bleachet választotta helyettünk). Maradhat így a csokoholista klubb tagja vagy sem? Eme döntést a csokoholista klubb tagjai közt szavazásra bocsátom;) ${ }^{2}$

A magyar nyelvben csokoholista alakban jelent meg az angol chocoholic szó. Az angol nyelvben sok olyan neologizmus tünt fel az elmúlt néhány évtizedben, mely a -holic képzővel jött létre (Lehrer 1998: 3). Ilyenek például a danceholic, sexaholic, sugarholic, workaholic (Sólyom 2010b: 277), sőt, legújabban a blogaholic. ${ }^{3}$ Az angolban ezek az alakulatok mind azt fejezik ki, hogy valaki túlzásba viszi a szótőben megadott dolog használatát, gyakorlását.

A magyar fordításban az elemzendő alakulat az -ista képzővel jelenik meg, így utal arra a személyre, aki az előtagban megjelenő dolog használatát, fogyasztását túlzásba viszi. A csokoholista alakulat megfelel a magyarban már régóta létező alkoholista, antialkoholista, kokainista, morfinista stb. szavak szemantikai felépítésében fellelhető logikának, bár grammatikai szempontból - valószínúleg éppen angol megfelelője hatása miatt - a csokoládé szónak csak egy „csonkja” jelenik meg benne.

Ezek az ismert szemantikájú szavak - és elsősorban az alkoholista, melytől csak egyetlen szótagban különbözik a neologizmus - vélhetően hozzájárulnak ahhoz, hogy a befogadó konvencionálisként létező jóváhagyó struktúrája (Tolcsvai Nagy 2001a: 48) viszonyítási alapként müködjön a csokoholista értelmezésekor, és segítséget nyújtson a neológ alakulat jelentésének megkonstruálásában, illetve értelmezésében.

A blend bemeneti tereiben megjelenő entitások közül az egyik tehát egy korábban már a nyelvben létező és a befogadó által jól ismert alakulat (ALKOHOLISTA), míg a másik bemeneti térben egy olyan szemantikai szerkezetü entitás áll, melyet a csokoládé túlzásba vitt fogyasztását gyakorló személyre vonatkozó szó jelöl. Az -ista képzős szó megjelenése az egyik bemeneti térben metonimikus kiterjesztés eredményeképpen jelenhet meg: bizonyos szerek fogyasztását túlzásba vivő egyénekre utal általánosságban. Másfelől a

2 Forrás: http://animgo.hu/index.php?reg=forum2\&forum=234\&page=2250 (letöltés ideje: 2011. július 22.).

Forrás: http://en.wiktionary.org/wiki/-holic (letöltés ideje: 2011. augusztus 5.). 


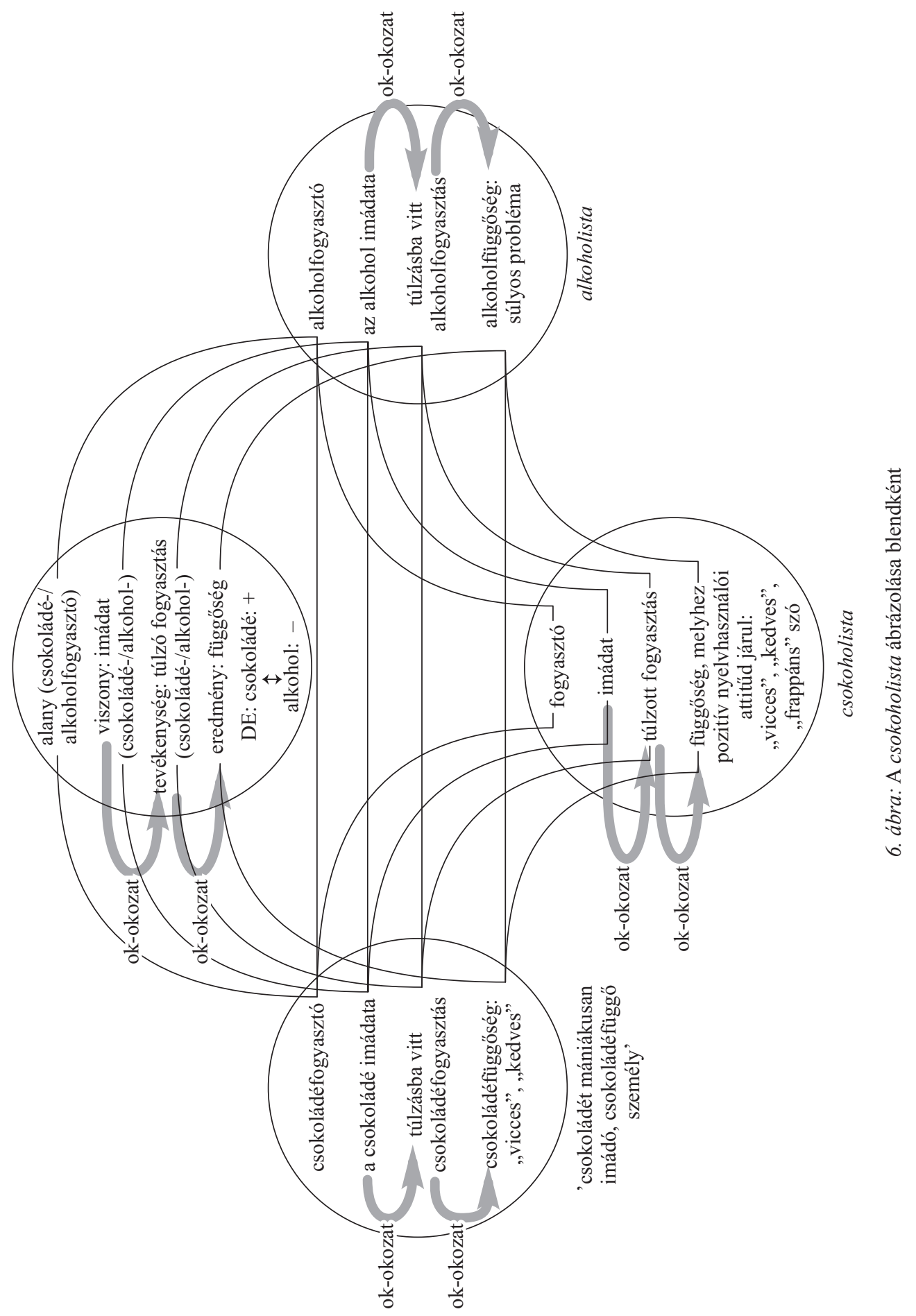


figyelem irányításában is részt vesz - egyértelművé teszi azáltal, hogy a cselekvésnek egy olyan aspektusát emeli ki, melynek segítségével a befogadó egyértelmüen azonosítani tudja, hogy az előtagban megjelölt termék túlzásba vitt fogyasztásáról van szó. Ennek a láncolatnak következtében jelenik meg metonimikusan (ok-okozati viszonyok során) a bemeneti terek esetében, a generikus térben és az integrált térben is az okozat, a kialakuló függőség (vö. Lehrer 1998: 20). Fontos ugyanakkor kiemelni, hogy míg a túlzásba vitt alkoholfogyasztás egyértelmüen betegségként értékelhetö, addig a túlzásba vitt csokoládéfogyasztáshoz a kérdőíves felmérések tanúsága szerint sok esetben pozitív attitüd kapcsolódik („vicces/ötletes/frappáns/kedves” szó). Ez a pozitív attitűd nagyon fontos különbség az alkoholista és a csokoholista megitélésében, és mint ilyen, szintén megjelenik az integrált térben.

A csokoholista szó szemantikai szerkezete a fentiek értelmében a fogalmi integrációs modell keretében a 6. ábrán látható módon ábrázolható (Sólyom 2011: 339).

A fent idézett fórumszövegben a beszélgetésben a két fórumozó magától értetődő módon használja a csokoholista szót. Számukra ennek a neologizmusnak a megértése vélhetően nem okoz gondot, sőt, egy közösséghez, egy szubkultúrához tartozást reprezentál - erre utalhat az is, hogy „csokoholista klub”-ot is szerveztek. Az idézett fórumszöveg 2007-ben keletkezett; kérdőíves felméréseimben 2012 elejéig összesen három alkalommal, 2008-ban, 2009-ben és 2010-ben kérdeztem meg az adatközlőket a csokoholista szó jelentéséröl. Az eredményekről elmondható, hogy a szó felismertsége folyamatos növekedést mutatott: a kezdeti $(2008,2009)$ felismerési arány (korcsoportoktól függően 11\%-20\%, illetve 44\%-71\%) 2010-re a 7. ábrán látható módon nőtt (az „A” típusú kérdőív esetében szövegkörnyezet nélkül, a „B” típusban szövegkörnyezetben olvashatták az adatközlők a szót, ez a jelen munkában közölt további diagramokra is hasonlóképpen igaz).

A csokoholista felismertsége a kérdőív típusának függvényében (\%) - 2010

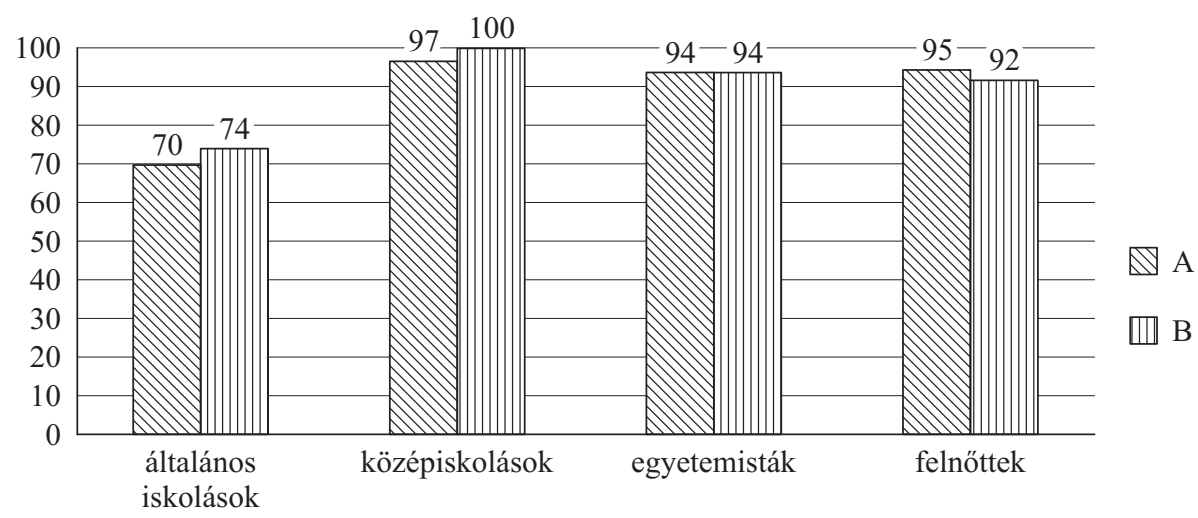

7. ábra: A csokoholista felismertsége 2010-ben 
A diagram azoknak a válaszoknak a százalékos arányát tartalmazza, ${ }^{4}$ amelyekben az adott évben olyan jelentésmagyarázatot adtak az adatközlők, amely megfeleltethető a kérdéses neologizmus jelentésének. A magyarázat lehetett egyszavas (például csokimán, csokimegszállott, csokoládéórült) vagy részletesebb körülírás. Az adatközlők a kérdöíveknek abban a pontjában, ahol arról írhattak, hogy van-e olyan neologizmus a kérdőívben szereplök között, mely kifejezetten tetszett vagy kifejezetten nem tetszett nekik, a fent említett pozitív jelentéstartalomnak megfelelően többször is említették a csokoholista szót mint pozitív példát, elsősorban a szó játékossága, frappáns volta miatt. Mindezek alapján feltételezhető, hogy a szó gyors terjedésében szerepe lehet a nyelvhasználók vele kapcsolatos pozitív attitüdjének is, vagyis a szó jelentésének értelmezésekor a nyelvhasználókban kialakul a Lehrer által is említett sikerélmény (Lehrer 2003: 370), amire a fent részletezett szemantikai szerkezet ad lehetőséget.

\subsubsection{2. esettanulmány: tanorexia, tanorexiás}

Az elmúlt évek neologizmusai között jelent meg a tanorexia ('túlzásba vitt napozás vagy a szoláriumozás túlzott, mániás használata, aminek az az oka, hogy a függő ember túlságosan sápadtnak érzi magát') főnév, majd a belőle képzett tanorexiás melléknév. A tanorexia angol eredetủ neologizmus, elötagja az angol tan- ('sárgásbarna') szó. A magyar nyelvben az angol főnév jelent meg néhány évvel ezelőtt. Az angol előtag jelentése a túlzásba vitt cselekvés (a napozás) eredményét jelöli, így a szó jelentésében metonimikusan az eredmény (a sárgásbarna szín) jelenik meg az ok (a napozás, szoláriumozás) helyén. Megjelenése óta több különböző magyar elnevezést is alkottak a jelenségre, az interneten például a barnakór(ság), barnulásfüggöség, szoláriumfüggőség szinonimákkal is találkozhatunk.

A tanorexia eredete valószínüleg a köznyelvben csak anorexiaként említett anorexia nervosa betegséghez kapcsolódik, mely az evészavarok egyik alapvetó típusa. Az anorexia grammatikailag az an- előtagból és az orexis ('vágy') főnévből tevődik össze, szó szerinti jelentése tehát 'az étvágy elvesztése'. ${ }^{5}$ Az anorexia mintájára az angol nyelvben az utóbbi években több, bizonyos betegségtípust megnevezö neologizmus is született; ezekből néhány már a magyarban is megtalálható, így a következők: drunkorexia ('olyan fogyókúra, melynek során ételt nem fogyasztanak, a szervezetbe bevitt kalóriamennyiséget csak alkoholfogyasztással fedezik'), fatorexia ('az anorexia ellentéte, kóros elhízás, melyet azonban a beteg nem észlel'), mamirexia ('a terhesség alatt a karcsúság érdekében koplaló, kórosan sovány kismamák betegsége'), illetve manorexia ('anorexia férfiak esetében'). Ezeknek az alakulatoknak az esetében megfigyelhetö, hogy az eredeti szótö (orexis) nem maradt meg minden esetben a szóban, illetve ha megmaradt, néhány eset-

\footnotetext{
4 A kérdőíves felmérésekben egy adatközlö több jelentésmagyarázatot is megadhatott, így a közölt százalékos arány minden elemzés esetében az összes kapott válaszhoz (és nem az összes adatközlő számához) viszonyított szinonim jelentésmagyarázatok arányára utal.

Forrás: http://hu.wikipedia.org/wiki/Anorexia_nervosa (letöltés ideje: 2011. augusztus 8.).
} 
ben metonimikus viszonyban áll az elötaggal, mely vonatkozhat a cselekvés eszközére (drunkorexia), eredményére (fatorexia, tanorexia), illetve magára a cselekvőre (mamirexia, manorexia). A felsorolt típusok közül talán csak a tanorexia az, melyekben az eredeti 'vágy' jelentés az előtagra vonatkozik - a tanorexiás beteg valóban napbarnított akar lenni. Úgy tủnik, hogy az orexia szó ezeknek az alakulatoknak az esetében a grammatikalizálódás útjára lépett, és olyan képzőként funkcionál, mely valamilyen kórra, betegségre utal.

A fenti alakulatok az elmúlt években azonos vagy hasonló alakban tủntek fel a magyarban is, nem kevés kiejtésbeli és megértési problémát okozva. Ezek közül a neologizmusok közül is az egyik legelső volt a tanorexia és a belőle képzett tanorexiás szó. Mindkettőröl olvashatunk magyarul, és több fórumszövegben is megjelentek, a melléknév például a következőben (kiemelések tőlem - S. R.):

Lükepék 2010. 06.11. 12:08:06

Az biztos, hogy túllihegik az egészet, viszon[t] tényleg nyomasztó a „forróság”, pedig lengedez a szél. Kinn a napon gyalogolni viszont nem jó (...), és el tudom képzelni, hogy a sok tanorexiás most rohan ki napozni, mert egy hónapig alig volt nap. És az viszont tényleg veszélyes. Az UV-sugárzásra mondják most nagyon, h erős 11-15h között, és tényleg lehet benne valami, mert simán van olyan 30-32 fokos nap, amikor nem érzi magát az ember enynyire vacakul kinn. ${ }^{6}$

A (20)-as számú bejegyzés szerzője az időjárással kapcsolatban nyitott fórumon reagált így a felmelegedésre. Az idézett szövegben a tanorexiás melléknév mindenféle jelentésmagyarázat nélkül jelenik meg. A fórum témájából (időjárás, felmelegedés) viszont lehet következtetni a szó jelentésére: bár a neologizmus az idézett szövegben újszerü stílushatású lehet, abból, hogy a vele megnevezett személyek ,rohan(nak) ki napozni”, a szöveg olvasói következtethetnek arra, hogy olyan személyekről lehet szó, akik szívesen napoznak, ha jó az idő.

A fent felsorolt -(o)rexia végü szavak mindegyikére, így a tanorexia, tanorexiás szavakra is jellemző, hogy angolnyelv-tudás nélkül szinte megfejthetetlen a jelentésük, vagy ha a velük első alkalommal találkozó befogadó megpróbálja is kitalálni, hogy mit jelenthetnek, a jelentésképzés folyamata során nem feltétlenül az angol szótőre asszociál, akkor sem, ha egyébként beszél angolul. Ezt látszanak alátámasztani a vonatkozó kérdőíves felméréseim eredményei is.

A 2009 tavaszán felvett kérdőíves felmérés során a négy korcsoport 108 adatközlöje között mindössze egy olyan javaslat volt ('szolimániás'), amely megegyezett a szónak a fent megadott, prototipikusnak mondható jelentésével.

Ez a neologizmus szerepelt a 2011-es kérdőív szavai között is. A kapott eredményeket elemezve a szó felismertségéről (tehát a megfelelő szinonimajavaslatok arányáról az

\footnotetext{
6 Forrás: http://forum.index.hu/Article/showArticle?go=101117104\&t=9024024 (letöltés ideje: 2011. augusztus 9.).
} 
A tanorexiás felismertsége a kérdőív típusának függvényében (\%) - 2011

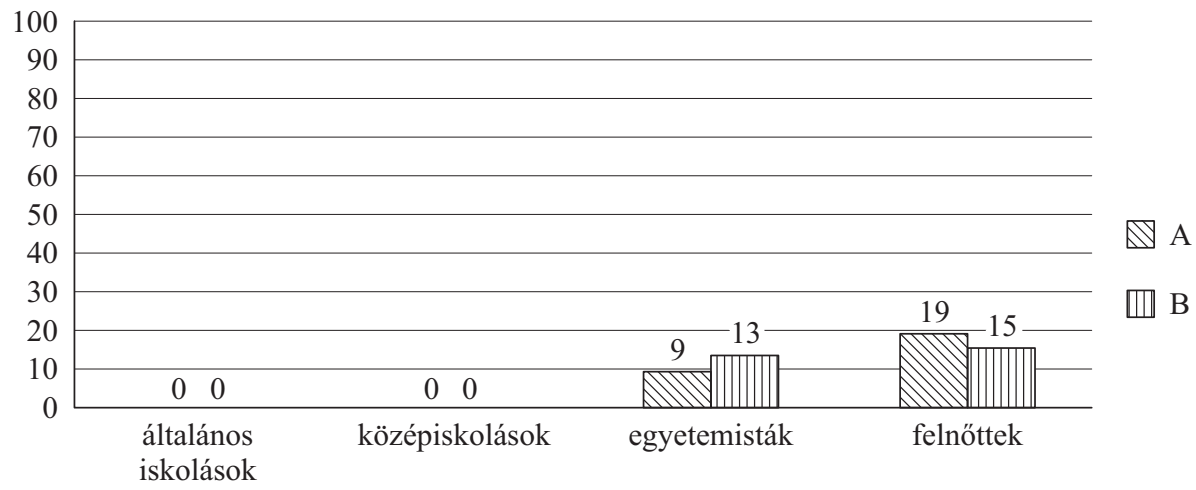

8. ábra: A tanorexiás felismertsége 2011-ben

összes kapott válaszhoz képest) a következők állapíthatók meg: az egyetemi hallgatók és a felnőttek körében nőtt azoknak az aránya (9\% és 19\%), akik a szó prototipikusnak nevezhető jelentésével megegyező szinonimát adtak meg. A kapott válaszokat a 8 . ábra diagramja szemlélteti.

A 2011-es évben az adatközlők a felvett kérdőívben a szó jelentésére is megadhattak magyarázatot, illetve szinonimákat is közölhettek. A kérdöív esetében kapott jelentésmagyarázatok, amelyek nem kapcsolhatók a szó „,valódi” jelentéséhez, 1. az anorexia fogalmához, 2. valamilyen rendellenességhez, 3. a tanulás fogalmához kapcsolódtak. Az 1. típusba tartozó magyarázatokban például a következőképpen magyarázták a szót az adatközlők: 'anorexiás', 'csont és bőr', 'étkezési zavaros', 'gebe', 'vékony' stb. A 2. típusban tüntek fel a 'beteg', 'túlplasztikázott', 'túlsúlyos', 'valamilyen rendellenesség', 'visszamaradott' stb. magyarázatok. A 3. típus azért is lehet jelentős a jelentéskonstruálás folyamatát vizsgálva, mert olyan folyamatot mutat be, mely a magyar anyanyelvü adatközlők asszociációira lehet jellemző, és elfogadható magyarázatot nyújthat arra, hogy miért lehetséges, hogy ez a neologizmus ilyen kis mértékben és ilyen lassan terjedt a köznyelvben. Ezekben a jelentésmagyarázatokban az adatközlők a tanulás fogalmával hozták kapcsolatba a szót: a tan+orexia alakulatot vagy a tanulás túlzásba vitelével, vagy annak hiányával magyarázták (például 'nagyon rágörcsöl a tanulásra', 'sokat tanuló', 'stréber', 'tanulásmániás', 'tanulást túlzásba vivő', illetve 'buta', 'nem tanuló', 'tanulásra képtelen', 'tanulást megvető és ezért alacsony intelligenciájú', 'tanulni utáló'). Az -orexia utótag az anorexia szóból ismerős lehetett a nyelvhasználóknak, így valamilyen betegségre, kóros állapotra asszociáltak, ám a tan- előtagot - magyar anyanyelvüekről lévén szó - a legtöbb esetben (81-91\%-ban) nem az angol jelentésének megfelelően értelmezték.

A tanorexiás szemantikai szerkezete is jól ábrázolható a fogalmi integráció folyamataként. Ennek a blendnek az egyik bemeneti terében megjelenik a tan- előtag, azonban a befogadók nem minden esetben tulajdonítják neki ugyanazt a jelentést: a szó használatakor feltételezett célstruktúra nem minden esetben feleltethető meg a befogadók jóváhagyó struktúrájának (Tolcsvai Nagy 2001a: 48). Ezért a folyamat során a tan- elötag vagy 
'tanulással kapcsolatos dolog' jelentésben jelenik meg (a tankönyv, tanóra, tanterem stb. mintájára), vagy pedig - jóval kisebb arányban - 'napozással kapcsolatos dolog'-ként. A kérdőívek eredményei alapján a blend másik bemeneti terében az ANOREXIÁs szó jelenik meg, egy olyan, ma már meglehetősen jól ismert alakulat, amelynek jelentésével a legtöbb magyar anyanyelvü nyelvhasználó tisztában van. Mindkét tan előtagú, tehát különböző entitást tartalmazó bemeneti tér esetében jellemző, hogy bennük ok-okozati, metonimikus kapcsolat lép fel, csakúgy, mint az anorexiást tartalmazó bemeneti térben: miként utóbbiban a túlzott mértékủ nem evés, úgy a napozás, illetve a tanulás is látható vagy egyéb érzékszervvel tapasztalható következményhez vezet.

A tanorexiás szemantikai szerkezetét a fentiek értelmében két blendben is ábrázolhatjuk, melyek között a különbség csak az egyik bemeneti térben található entitás jelentésében lesz.

Az első esetben az ábra a szónak a prototipikus jelentését ('mániásan sokat napozó, szoláriumozó’) adja meg, a 9. ábrán látható módon.

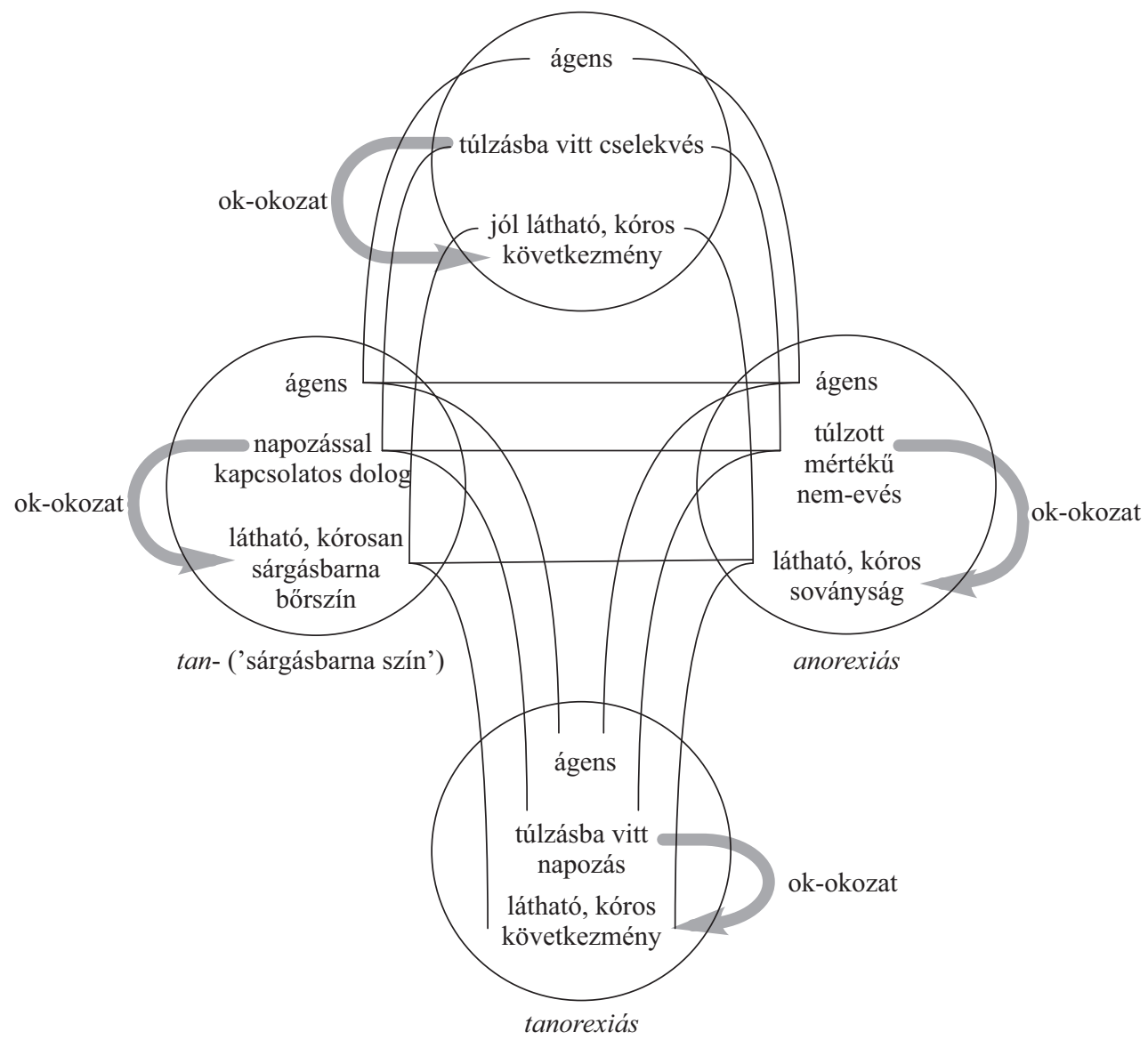

9. ábra: A tanorexiás ábrázolása blendként (valódi jelentés) 
A második esetben a tanorexiás jelentésének az a konstruálási típusa (nem prototipikus jelentése) ábrázolható, mely tipikusan a magyar anyanyelvü nyelvhasználók nagy részének válaszaiból rekonstruálható. Ebben az esetben a kérdöívben megadott válaszok alapján a neologizmusnak 'valamilyen tanulással kapcsolatos rendellenesség' jelentésmagyarázata körvonalazódik. Ez a rendellenesség az adatközlők válaszaiban vagy 1. a túlzásba vitt tanuláshoz kapcsolódik (a kapott válaszok között ilyen például az 'agyontanulja magát', 'könyvmoly', 'stréber', 'tanulásmániás'), vagy 2. a kevés tanuláshoz, a tanulás akadályaihoz kapcsolódik (a kapott válaszok közül néhány: 'buta', 'tanulásellenes', 'tanulászavarban szenved', 'tanulni utáló'), a 10. ábrán látható módon.

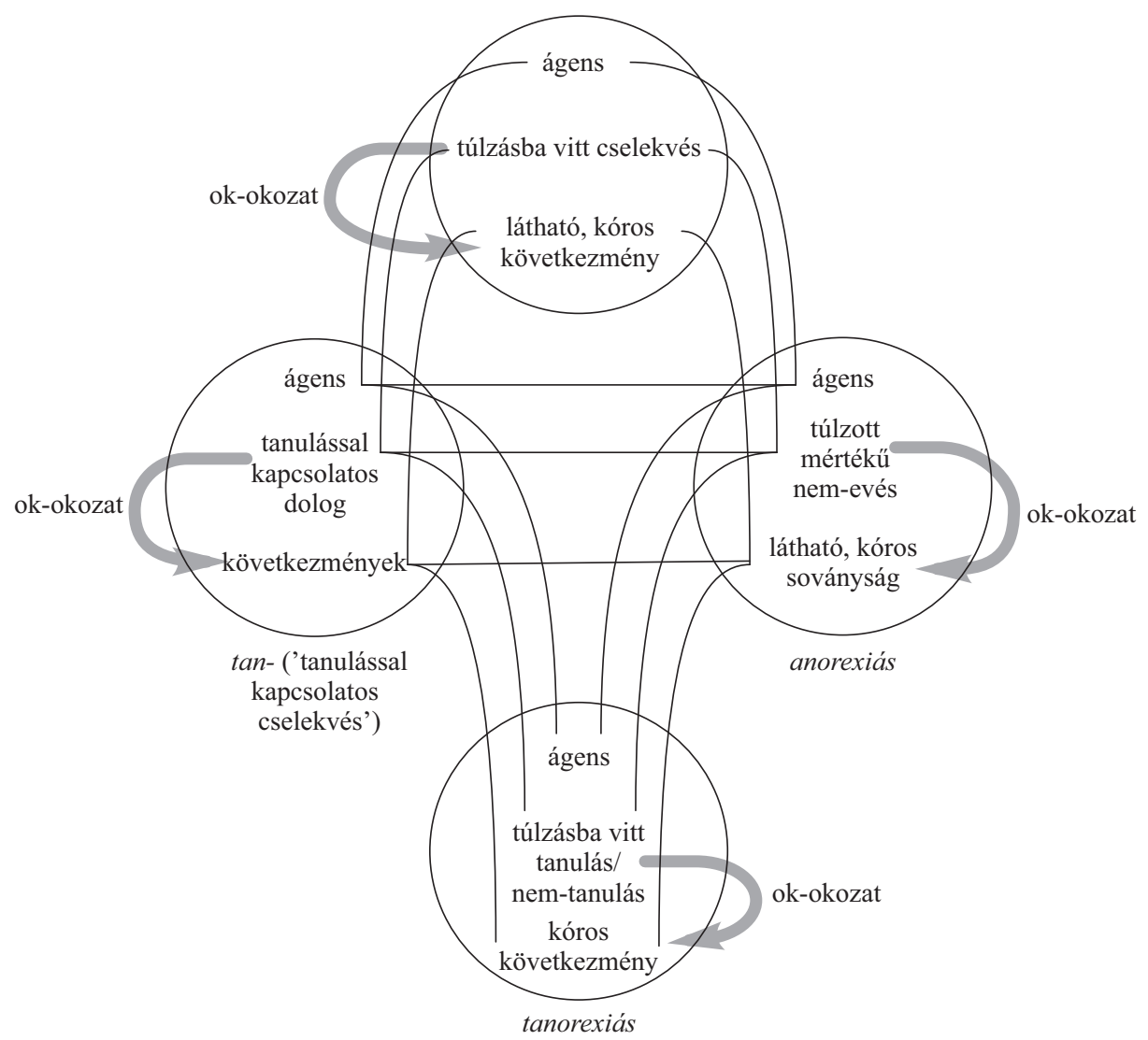

10. ábra: A tanorexiás ábrázolása blendként (nem prototipikus jelentés)

Az adatközlőknek a kérdőív III. és IV. pontjában lehetőségük volt arra, hogy leírják, volt-e a megadott neologizmusok között olyan, amely kifejezetten tetszett vagy kifejezetten nem tetszett nekik, és ha volt ilyen, megindokolják, hogy miért. A tanorexiást jellemző módon a nem tetsző szavak között sorolták fel azok, akik megemlítették. Megjegyzéseik alátámasztják a fent vázolt értelmezési folyamatot: az adatközlők vagy 
1. a szó jelentésének érthetetlenségét kifogásolták („,nem értem a szót”, „,nem érteni pontosan, mit takar a szó”), vagy 2. félreérthetőségét emelték ki („könnyen félreérthető”, „benne van egy betegség neve”, ,erőltetett”), esetenként pedig 3. a hangzását tartották rossznak („rosszul hangzik”, „csúnya szó”, „magyartalan”, „idegenül hat”). A jelentéskonstruálás bizonytalanságából fakadó negatív véleményt tehát sok esetben a szónak a magyar anyanyelvüek számára érezhetően angol eredete is fokozta.

\subsubsection{3. és 4. esettanulmány: két -szitter utótagú összetétel elemzése}

A következő két bemutatandó példa két olyan összetett szó, melynek utótagja egyaránt az angol eredetü, e neologizmusokban magyar helyesírással írt szitter szó. Ez az angol sit ige származéka, melynek jelentése az Oxford szótár szerint 'take care of children' (Oxford 2005: 1427), 'gyerekekre vigyáz'. A szó a magyar nyelvben a Minya (2007) által is említett bébiszitter alakulat utótagjaként jelent meg korábban. Ezt a szót is lehet látni magyar helyesírással írva: az Osiris Kiadó-féle Helyesírásban bébiszitter olvasható (OH. 2005: 503), az ÉKsz. ${ }^{2}$-ban viszont még angol helyesírással babysitterként szerepel (ÉKsz. ${ }^{2}$ 2003: 80). A bébiszitter utótagjának segítségével az elmúlt években nemcsak kisgyerekekkel, hanem más családtagokkal (dédiszitter), sőt, az utóbbi időben (hobbi)állatokkal kapcsolatban (kutyaszitter, höriszitter, patiszitter) is létrejöttek összetételek. Úgy tủnik tehát, hogy ezen alakulatok esetében a szitter utótag jelentése metonimikusan kiterjed, és - az angol nyelvhez hasonlóan - 'valakire, valamire vigyázó személy' jelentésủ lesz (mint ahogy említett szótárban olvasható, az amerikai angolban maga a sitter

főnév is jelenthet 'bébiszitter'-t). Új jelentésében így különböző élőlényekkel (emberekkel, állatokkal) kapcsolatban a magyar nyelvben is megjelenhet a szitter utótag.

A 2010-ben és 2011-ben felvett kérdőíves felméréseim tapasztalatai szerint a jelentéskonstruálás folyamata mindkét szó esetében a jobban elterjedt bébiszitter szó segítségével történik, amelyik így az egyik bemeneti térben jelenik meg e szavak szemantikai szerkezetének blendként történő ábrázolásában.

\subsubsection{3. esettanulmány: kutyaszitter}

A kutyaszitter szó az elmúlt években internetes fórumszövegekben is feltünt. A (21)-es szövegrészlet egy kutyabarátok által indított fórumon jelent meg. A szöveg írója bejegyzésében új témát vet fel, aktuális problémájának megoldására keres kutyaszittert (kiemelések tőlem - S. R.):

Pronizsuzsa 2006. aug. 14. hétfő 20:46

Jó estét Mindenki!

Mivel kutya-szitter topic nincsen, itt érdeklődöm, hogy esetleg netalántán két db. leánykutyámat (6 éves és 3 éves) 6 napra külön-külön vagy együtt bevállalná-e megőrzésre valaki(k). Aug. 25 de. től aug. 30-án késő délutánig. Végső esetben meg tudom oldani, hogy 
itthon maradnak és a szomszéd felügyeli őket minden nap. Ha mégis akadna vállalkozó nagyon hálás lennék. Sajnos ugy alakult, hogy a fiam pont arra az egy hétre megy vidékre dolgozni, amikor mi elutazunk Tunéziába. Szóval....... ha mégis.......

Bonnie, Ashley és Meggie ${ }^{7}$

A neologizmus rögtön a megszólítás utáni első mondatban feltünik, a szöveg írója mindenféle magyarázat nélkül használja a szót, majd részletesen elmagyarázza a kialakult helyzetet, amelynek megoldásában a fórumozók segítségét kéri. A bejegyzést olvasó fórumozók feltehetően olyan jóváhagyó struktúrát (Tolcsvai Nagy 2001a: 48) birtokolnak, melynek a neologizmust tartalmazó szöveg mint célstruktúra nagymértékben (vagy teljes egészében) megfeleltethetö, így a jóváhagyás és ezáltal a megértés folyamata részükről gyorsan megtörténik. Egyikük például így reagált a fenti bejegyzésre (kiemelések tőlem - S. R.):

manvo 2006. aug. 15. kedd 8:00

Én is szívesen segítek....

Nyissunk Szitter-topikot, szerintem hasznos lenne. ${ }^{8}$

A kutyaszitter szerepelt a 2010-es kérdőíves felmérés szavai között is: az eredményekből látható, hogy a 216 adatközlő nagymértékben sikerrel járt a jelentéskonstruálás folyamatában, függetlenül attól, hogy szövegkörnyezetben vagy anélkül olvasták a szót. A 11. ábra diagramja azoknak a válaszoknak az arányát mutatja, amelyek a kutyaszitter prototipikusnak tekinthető jelentésével ('a gazda távollétében általában pénzért a kutyára vigyázó, a kutyát gondozó személy’) azonosak voltak.

A kutyaszitter felismertsége a kérdőív típusának függvényében (\%) - 2010

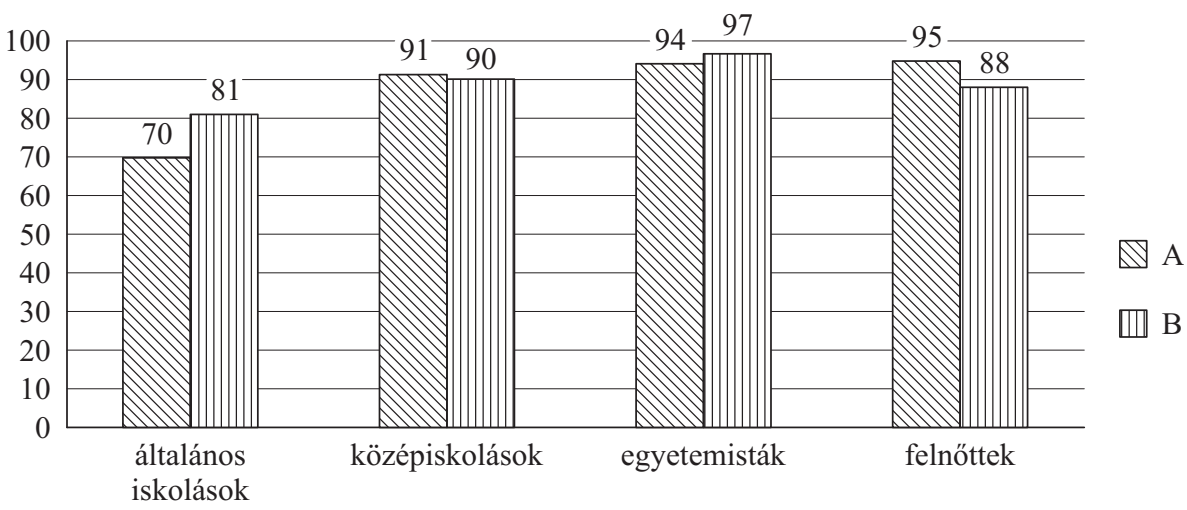

11. ábra: A kutyaszitter felismertsége 2010-ben

Forrás: http://pet.site.hu/viewtopic.php?p=78483 (letöltés ideje: 2011 . március 10.). Forrás: http://pet.site.hu/viewtopic.php?p=78483 (letöltés ideje: 2011. március 10.). 


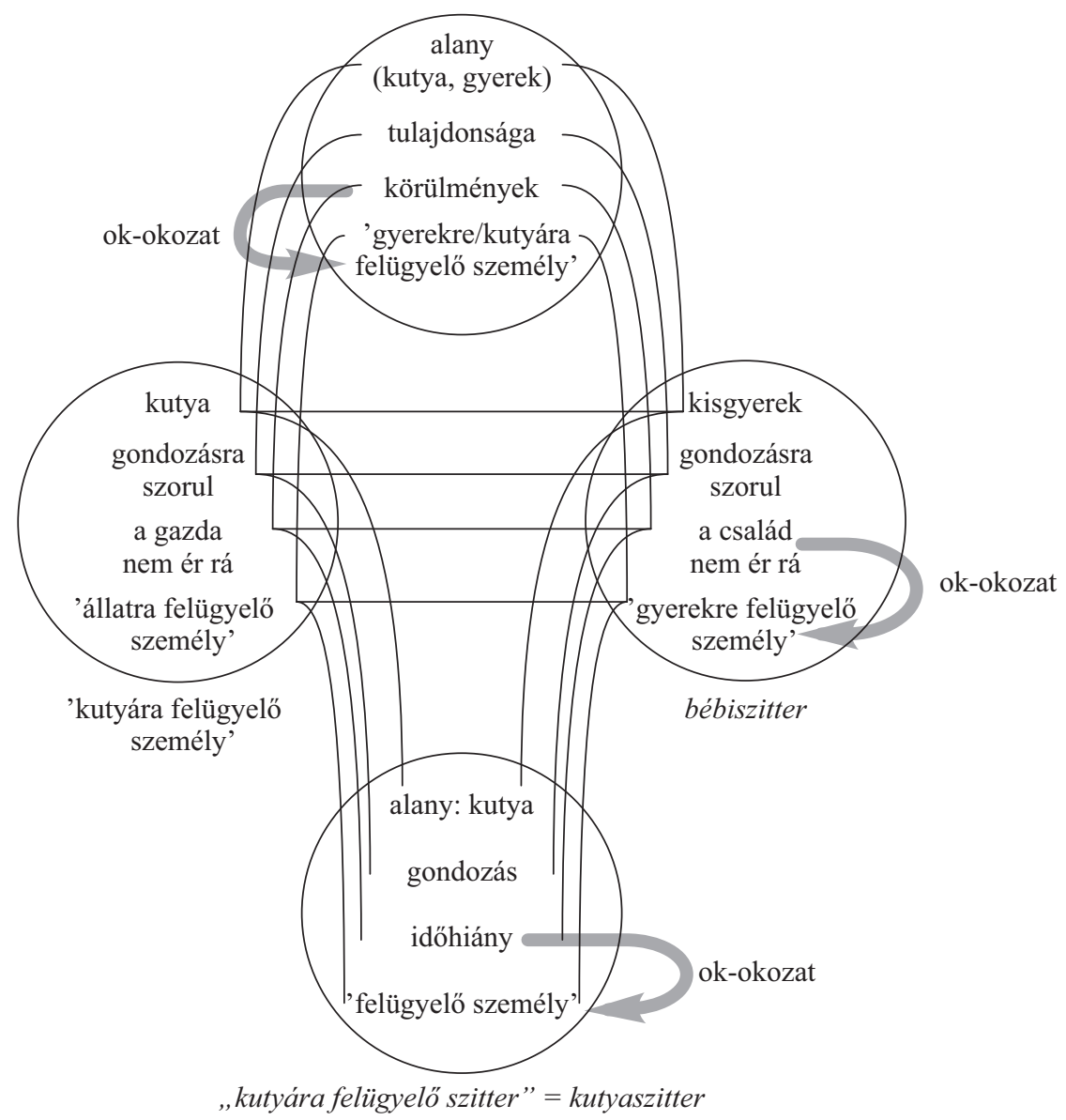

12. ábra: A kutyaszitter ábrázolása blendként

A kapott eredmények is bizonyítják, hogy a kutyaszitter szerkezetében két olyan jelenség, a kutya és a szitterkedés viszonya kerülhet egymással dinamikus, a jelentésképzés folyamatát elősegítö kapcsolatba, melyről a nyelvhasználóknak általában sok elözetes tapasztalatuk van. Az összetétel előtagja, a kutya és a hozzá kapcsolódó jellemzők (háziállat, gazdája van, gondozni kell, foglalkozni kell vele) a nyelvhasználók számára a hétköznapi életből jól ismertek. A szitter utótag első hallásra, első olvasásra elgondolkodtató és újszerủ stílushatású lehet a befogadók számára, viszont segítségével azonnal előhívható a már említett, begyakorlottabbnak számító bébiszitter szó; e szó utótagjának segítségével felidéződhet a befogadók elméjében a szitterkedés és a hozzá kapcsolódó jellemzők (vigyáz, felügyel valakire, gondoz valakit). Egy-egy új nyelvi forma létrejöttét a kategorizáció szempontjából vizsgálva elmondható, hogy e jelenségek szerves részét képezik az emberi elme feladatmegoldó, kreatív müködésének: „a prototípus ismerete könnyebb hozzáférést tesz lehetővé a használatban megjelenő, olyan periferikus példányokhoz, amelyek újak a számunkra" (Geeraerts 1997: 110). A prototípuselv implikálta 
jelenségek az emberi gondolkodás dinamikusságának leírásában a szemantikai változásoknak, így az új jelentések kifejlődésének is magyarázatául szolgálhatnak (Geeraerts 1997: 115). A kutyaszitter elö- és utótagja így hozza kapcsolatba a neologizmus jelentésének megfejtéséhez szükséges jellemzőket. A fent leírtak alapján ennek az összetett szónak a szemantikai szerkezete is eredményesen ábrázolható a Fauconnier-Turner-féle fogalmi integrációs modellben. A blend bemeneti tereiben a kutyára felügyelö személy és a kisgyerekre felügyelö személy = 'bébiszitter' fogalma kerül egymással dinamikus kapcsolatba. A 'kutyára felügyelő személy' jelentésủ entitásnak minden tulajdonsága ismert (egy gondozásra szoruló állatra vigyáz, mert annak gazdája nem ér rá), de korábban a magyar nyelvben csak körülírással lehetett kifejezni a szót. A 'kisgyerekre felügyelő személy' jelentésủ entitásnak is ismertek a tulajdonságai (kisebb gyerekre vagy gyerekekre vigyáz, mert a szülők nem érnek rá), és megfelelő szó is van a jelenség kifejezésére (BÉBISZITTER). A blend generikus terében a két helyzetből következő közös jellemzők jelenhetnek meg (adott egy alany, akire vigyázni kell olyan körülmények miatt, melyek mindkét helyzetre jellemzőek, ezért szükséges egy olyan személy jelenléte, aki ellátja ezt a feladatot). Az integrációs folyamat minden terében megjelenik az a metonimikus ok-okozati kapcsolat, amelynek alapját az adja, hogy a család (szülö, gazda) nem rendelkezik elegendö idővel, és ennek a helyzetnek a következtében szittert fogad. A blend integrált terében a bemeneti terekből és a generikus térből a legfontosabb aspektusok válnak hangsúlyossá a 12. ábrán látható módon.

\subsubsection{4. esettanulmány: dédiszitter}

A másik szitter utótagú neologizmus, melynek szemantikai szerkezetét és a hozzá kapcsolódó vizsgálatok eredményeit bemutatom, a dédiszitter. A szóban az utótag - a kutyaszitterhez hasonlóan - szintén 'valakire, valamire vigyázó személy' jelentésủ, a dédi elötaggal együtt 'idős, gyakran beteg emberre általában pénzért vigyázó személy'-t jelent.

A szó az elmúlt években feltünt internetes fórumok szövegeiben is. A most elemzendő szövegrészletben a kérdező a személyes problémájával kapcsolatban kér tanácsot. A kapott hozzászólások közül azt választottam ki, melyben a dédiszitter szó szerepel (kiemelések tőlem - S. R.):

A kérdés 2009. 04. 23. 14:09

Elhanyagolnak a testvéreim, a barátaim, a párom, az egész környezetem. Mit tegyek, hogy újra „,központban” legyek? (...)

Az egyik válasz 2009.04.24.09:26

(...) Ha Bp-i vagy, van délelöttönként is egy csomó program, amire el lehet menni és ismerkedni, előadások, tanfolyamok, klubok, stb. (...) Ha értesz valamihez behatóbban (pl. szépen énekelsz), vagy olyan az iskolai végzettséged, vállalhatsz magántanítványokat is, vagy 
ha nem, felügyelhetsz gyerekekre vagy öregekre (babysittert és dédiszittert is sokan keresnek). Így még pénzt is kereshetsz + szintén új emberekkel ismerkedhetsz meg. (... $)^{9}$

Az idézett hozzászólás írója egy új, „neológ” jelenség használatára vállalkozik, tehát korábbi tapasztalatai alapján igyekszik definiálni azt a jelenséget, amelyet egyébként csak körülírással tudna megnevezni. A dédiszitter szó jelentésének megértését a fenti szövegkörnyezetben nagymértékben segíti, hogy a szitter utótag a nyelvhasználók számára egy már begyakorlott összetétel (bébiszitter) jelentésszerkezetét is hozzáférhetővé teszi, csakúgy, mint a kutyaszitter szó esetében. A bébiszitter jelentésszerkezete a befogadó figyelmét a szitter feladatai (gondozás, felügyelet) felé irányíthatja; az író ráadásul már a zárójelben megjegyzett rész előtt meg is adja a két szó jelentését (,felügyelhetsz gyerekekre vagy öregekre"), a megértést így várhatóan nem akadályozza a dédiszitter szó neológ jellege.

A dédiszitterrel kapcsolatban a 2011-ben felvett kérdőíves felmérésben ismét megkértem az adatközlöket, hogy próbálják megmagyarázni ennek a neologizmusnak a jelentését. Azoknak a válaszoknak az aránya, amelyek megegyeztek a neologizmus ,valódi”-nak tekinthető jelentésével, tehát tartalmazták a VIGYÁZÁs, FELÜGYELET, illetve az IDÖS EMBER, IDŐS ROKON fogalmát, a felmérésben részt vett 180 adatközlö esetében a 13. ábra diagramján látható módon alakult.

A dédiszitter feismertsége a kérdőív típusának függvényében (\%) - 2011

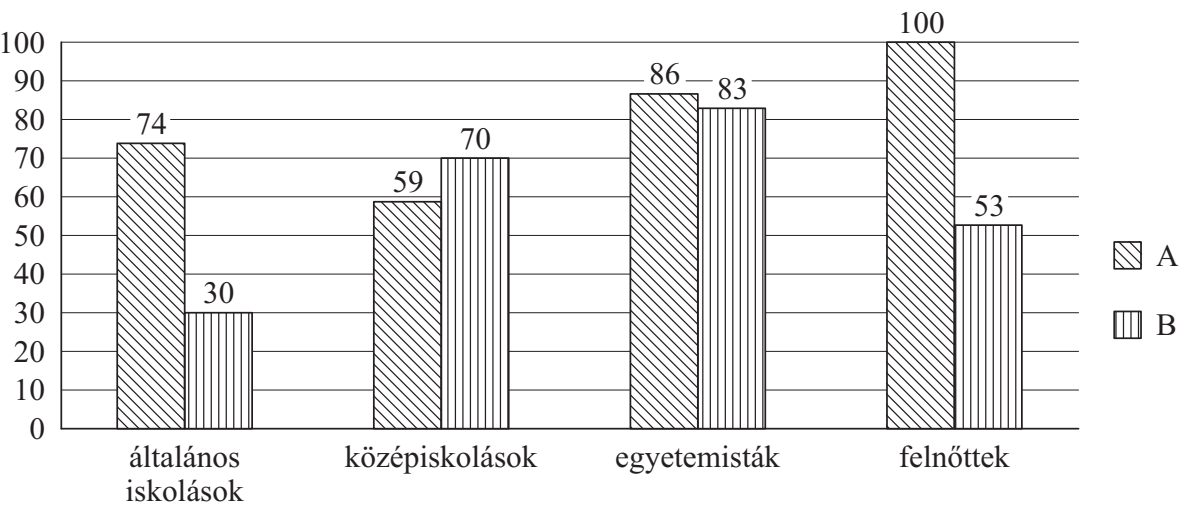

13. ábra: A dédiszitter felismertsége 2011-ben

A kapott válaszokat megvizsgálva több jelenségre is fény derült a dédiszitter szemantikai szerkezetének értelmezésével kapcsolatban. A, valódi” jelentéssel nem megegyező jelentésmagyarázatok között nagy arányban feltünt az a magyarázat, mely szerint ’idős

9 Forrás: http://www.gyakorikerdesek.hu/csaladi-kapcsolatok_egyeb-kerdesek_220629-elhanya golnak-a-testvereim-a-barataim-a-parom-az-egesz-kornyezetem-mit-tegye (letöltés ideje: 2011. március 25.). 
családtag vigyáz egy kisgyerekre', a folyamatban aktívan közremüködő ágens tehát a DÉDI fogalmi kategóriába sorolható családtag lett. A kérdőíves felmérésben kapott válaszok alapján elmondható, hogy a neológ szóösszetétel szemantikai szerkezetének felépítésében a szemantikai megfeleltethetőségen túl valószínüleg a bébi és a dédi előtagok hangzásbeli hasonlósága is szerepet játszik: fonológiai szempontból nem elhanyagolható a rím szerepe a dédiszitter kialakulásának folyamatában - a rímnek a kreatív szóösszetételek létrejöttében betöltött szerepére hívja fel a figyelmet Benczes (Benczes 2006: 148-149; 2010: 228-229). ${ }^{10}$ A dédiszitter-bébiszitter kapcsolatot vizsgálva megállapítható, hogy e szavak előtagja, a bébi és a dédi szavak azonos magánhangzókat tartalmaznak, végződésük rímel egymásra, és szótagszámuk is azonos, így a neológ alakulatban megjelenő dédit olvasva a befogadók könnyen asszociálnak a bébire. A két pólus, a fonológiai és a szemantikai szempontból egymásnak megfeleltethető jellemzők együttesen teszik lehetővé a neologizmus létrejöttét, alakítják jelentését, és segítik a nyelvhasználót a jelentés konstruálásában; ehhez járul még az a jellemző, hogy a létrejövő alakulat humoros és eufemisztikus, kedveskedő is lesz. A dédiszitter szó érdekessége éppen e két dimenzió egymásba játszásában rejlik, így többoldalú blendként ábrázolható. Szemantikai szempontból mind a bébiszitter, mind az 'idős emberre felügyelő személy' jelentésű entitások szemantikai felépítésében azonos szempontú jellemzők kapnak hangsúlyt. Ezek a következők: az alany életkora, állapotának az a jellemzője, hogy gondozásra szorul, az a külső körülmény, hogy a családja nem ér rá őt gondozni, valamint az utóbbi jellemző következménye, a felügyelő személy szükségessége. A családtagok időhiánya és a gondozó személy szükségessége között metonimikus ok-okozati kapcsolat mutatható ki. A neologizmussal szinonim entitás jelentése így lesz 'idős emberre felügyelő személy'. Az ezen entitás és a BÉBISZITTER szemantikai szerkezete által kialakított integrált térben pedig az 'idős emberre felügyelő szitter' jelentés profilálódik. Ezzel lép aztán kapcsolatba a már tárgyalt fonológiai pólus, és így, együttesen hozzák létre az integrált térben megjelenő dédiszitter alakulatot, amelynek szerkezete a fenti modellben a 14. ábrának megfelelöen ábrázolható (vö. Sólyom 2012c: 288).

\subsubsection{5. esettanulmány: gerillakertész}

A gerillakertész ('közterület-szépítés céljából illegálisan növényt ültető aktivista') feltünt az elmúlt években az internetes fórumok szövegeiben is.

Egy gerillaakciót meghirdető bejegyzéshez az egyik hozzászóló említi a gerillakertészetet: ${ }^{11}$

10 Ezúton köszönöm Benczes Rékának, hogy felhívta a figyelmemet a rím fontosságára a neologizmusok esetében.

11 Napjainkban egyre nagyobb számban tünnek fel különböző „gerillaakciók” a magyar nyelvben is, 2012 májusa és 2013 augusztusa között például a következők: gerillakampány, gerillakötés, gerillatárlat, gerillawakeboard. 


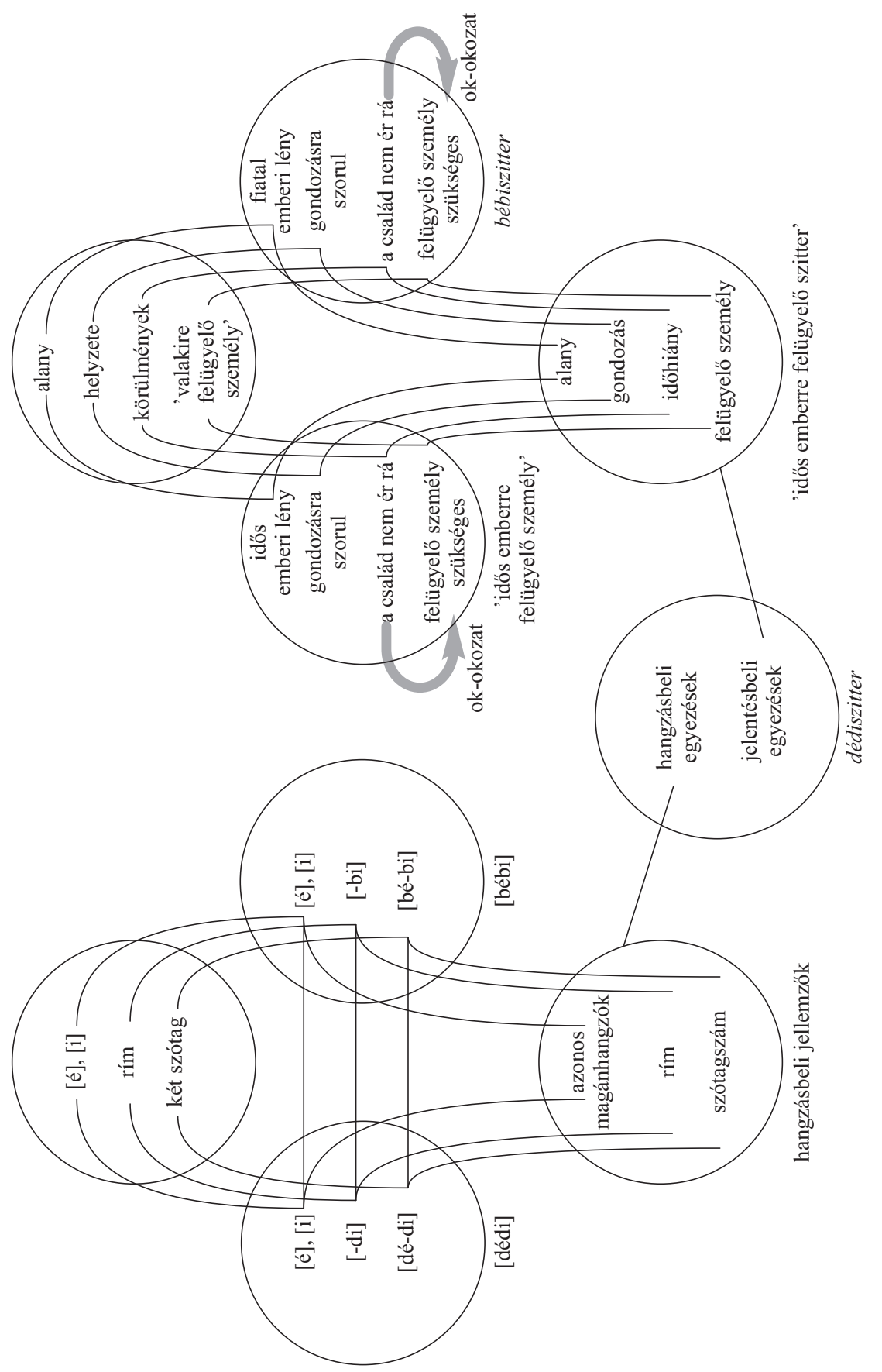

14. ábra: A dédiszitter ábrázolása blendként 
ZsuR 2009.01.31 17:36:20

(...) Nekem egy felo gondolat van azzal amit csinal (inkabb hogyan?), hogy olyan embereket is vonz, akik a gerilla kerteszkedesben tobb gerillat latnak mint kerteszkedest. ${ }^{12}$

A (25)-ös számú idézet a szöveg szerzőjének azokra a mentális folyamataira is rávilágít, amelyek feltehetően a legtöbb magyar anyanyelvű olvasó elméjében végbemennek a vizsgált neologizmussal való első találkozás alkalmával. A GERILLASÁG és a KERTÉSZKEDÉS kiemelődését az értelmezési folyamatban implikálhatja a szó grammatikai felépítése is, az, hogy ennek a két összetételi tagnak a segítségével jött létre a neologizmus.

A 2011 nyarán végzett kérdőíves felmérés során kapott válaszokból kiderült, hogy az adatközlök számára a fent vázolt összefüggések sok esetben segítettek a neologizmus jelentésének megkonstruálásában. Azoknak az aránya, akik a neologizmus jelentésével megegyező módon magyarázták a jelentését, 10\% és 37\% között volt. Az eredményeket a 15. ábra diagramja mutatja be.

A gerillakertész felismertsége a kérdőív típusának függvényében (\%) - 2011

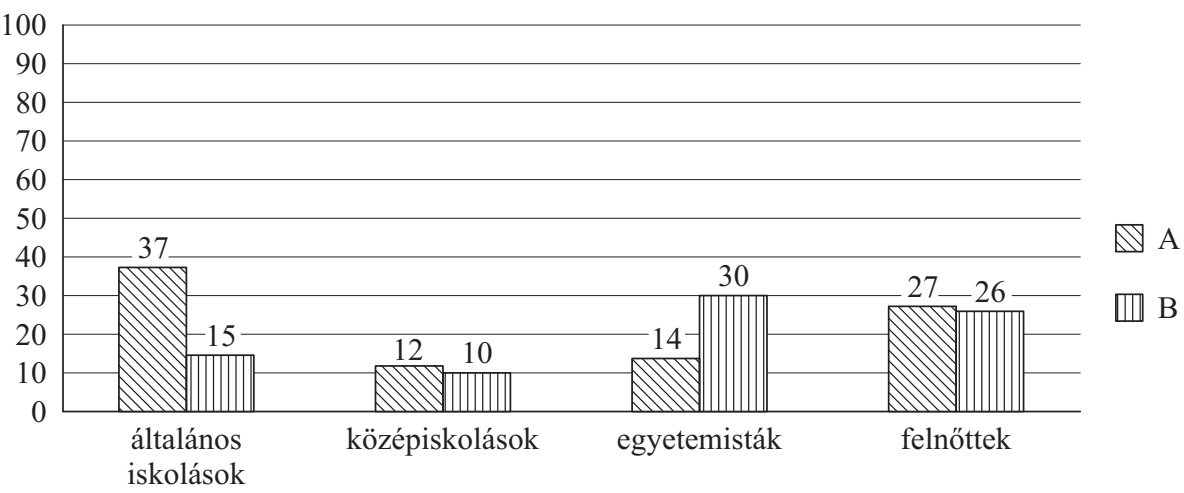

15. ábra: A gerillakertész felismertsége 2011-ben

Ha elfogadjuk a fenti megállapítást, és a GERILLASÁG, illetve a KERTÉSZKEDÉs fogalom szerepének jelentőségét a jelentéskonstruálás folyamatában, ismét felmerülhet a fogalmi integrációs modell alkalmazásának létjogosultsága. A fent részletezett jellemzők értelmében ennek a szónak az esetében olyan kétoldalú fogalmi integrációról van szó, amelyben a bemeneti terekben a GERILLASÁG és a KERTÉSZKEDÉs jellemzői idéződhetnek fel a befogadók elméjében. A gerilla és a kertész munkájának célja, terepe, eszköze(i), illetve szervezettsége lehetnek azok az aspektusok, amelyek megjelennek a bemeneti terekben és dinamikus asszociációkat hoznak létre a generikus térben. A felsorolt jellemzők a GERILLA vonatkozásában a HÁBORÚ, HARC metaforához kapcsolódnak, és a gerillakertész

12 Forrás: http://forum.index.hu/Article/showArticle?na start $=120 \&$ na step $=30 \& \mathrm{t}=9187220 \&$ na order= (letöltés ideje: 2011. július 27.). 
tevékenységében a KÖZTERÜLET SZÉPÍTÉSE HÁBORÚ fogalmi metaforában teljesednek ki. Az integrált térben ennek a háborúnak a célja, helyszíne, eszközei és illegalitása jelenik meg; itt profilálódik a neologizmus jelentésének szervezésében különösen fontos jellemzö: ez a KERTÉSZKEDÉs közterületen, illegálisan zajlik. A fentiek a fogalmi integrációs modellben a 16. ábrán látható módon ábrázolhatók.

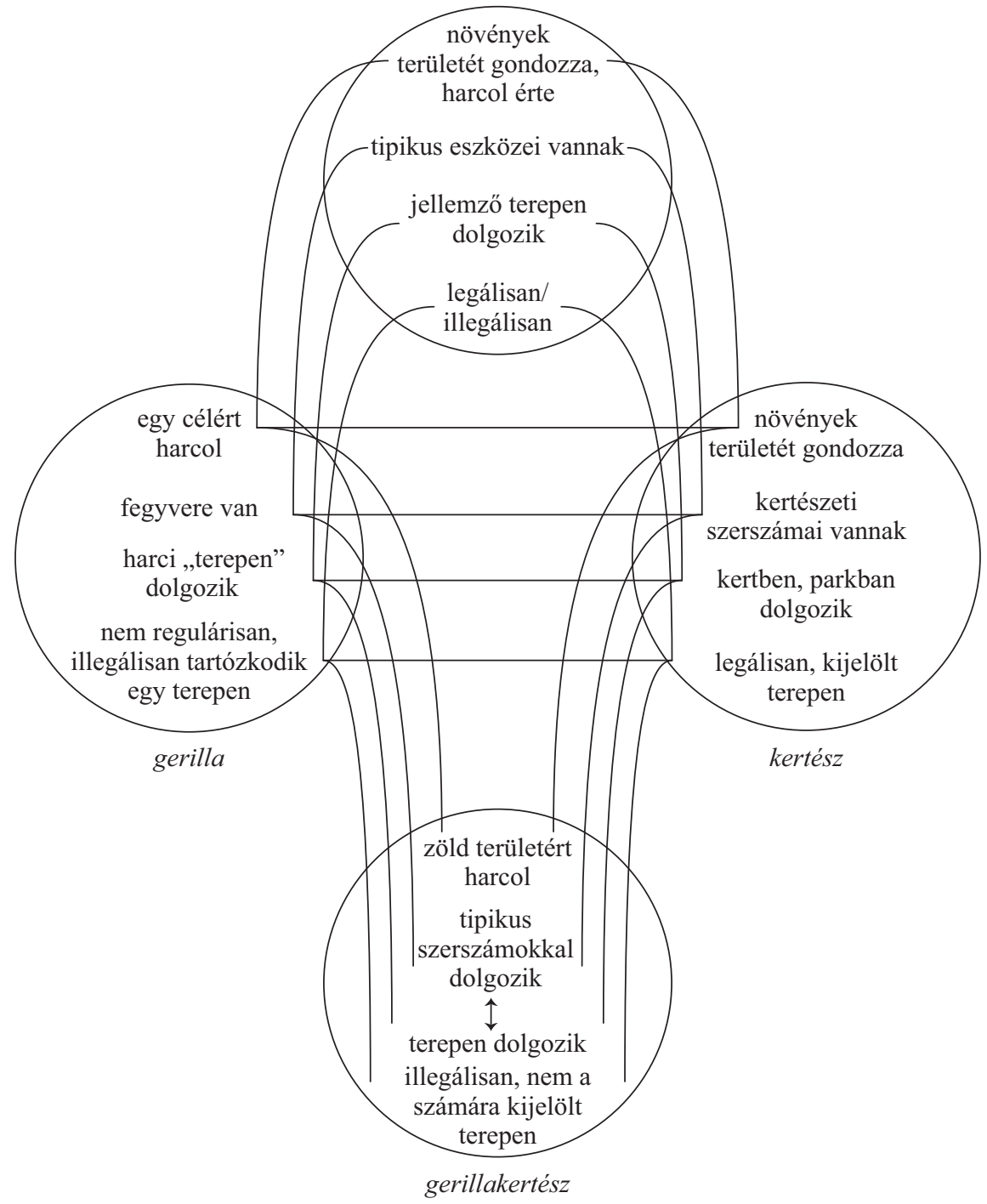

16. ábra: A gerillakertész ábrázolása blendként 
Érdemes röviden megvizsgálni az olyan jelentésmagyarázatokat is, melyeket a kérdőívet kitöltő adatközlők a szóval kapcsolatban adtak, de nem egyeznek a neologizmus kikövetkeztethető jelentésével. Úgy gondolom, hogy ezek az értelmezési folyamatok is rávilágíthatnak a jelentésképzés folyamatában azokra az aspektusokra, amelyek alternatív módon megjelennek az összetételt olvasva. Ezekben a szómagyarázatokban a neologizmussal kapcsolatban sok esetben a GERILLA más jellemzői profilálódtak, például: 'mindent kiirtó, kivágó kertész', 'zöldséget lopó ember', 'rosszarcú, nagydarab kertész', 'drogtermesztő'. (Az általános iskolás korosztály adatközlői pedig - nem ismervén a gerilla szó jelentését - több esetben gorillaként értelmezték az előtagot.)

\subsubsection{6. esettanulmány: kanapészörf}

A kanapészörf szóösszetétel az angol couchsurfing szó tükörfordításaként jelent meg a magyarban az elmúlt években. Jelentése 'ingyenes szállás biztosítása a lakásunkban turistáknak, amikor pedig mi utazunk valahova, az adatbázis segítségével mi is kereshetünk hasonló szállást”. A szálláskeresés és -biztosítás e formájával kapcsolatban hangsúlyozni kell, hogy nem szükséges a kölcsönösség a szállásadó és a szállást igénybe vevő között: az internetes honlap lehetőséget biztosít rá, hogy akkor is hirdethessünk, hogyha csak szálláslehetőséget akarunk biztosítani, de akkor is kereshetünk szállást utazásunkhoz, ha mi magunk nem nyújtunk hasonló szolgáltatást. A kanapészörf jelentése ráadásul nemcsak a szállásbiztosításra terjed ki, hanem egyre gyakrabban egyéb szolgáltatásokat (például a turisták kalauzolását, szórakoztatását a városban) is magában foglal.

Erről az összetett szóról elmondható, hogy napjainkban a magyar anyanyelvü nyelvhasználók mind az angol, mind a magyar változatát használják; a 2011-ben felvett kérdöíves felmérésemben kapott szinonimák között is feltünt a couchsurfing mint a kanapészörf megfelelöje. A következő két internetes hozzászólásban is erre a két variációra látunk példát (kiemelések tôlem $-\mathrm{S}$. R.). ${ }^{13}$

kem 2010-10-23 03:48:01

NAhh hogy fölélesszem a topicot, hétfön jön hozzám egy napra egy kanapészörfös Franciaországból (:) juppíííí

Mawyx 2010-11-14 17:11:54

1 hét múlva káucsszörfölnék, kirándulni készülök. Regelve vagyok az oldalon egy ideje, de eddig nem mertem belevágni.

13 Forrás: http://itcafe.hu/tema/couchsurfing_com_kulfoldi_turistak_vendeglatasa_es_viszont/hsz_ 1-50.html (letöltés ideje: 2011. január 05.). 
A szó felismertségével kapcsolatban megállapítható, hogy a kérdőíves felmérésben a két legfiatalabb korosztály tagjai közül senki sem adott meg „valódi” jelentésével azonos szinonimát a szóra. Az egyetemi hallgatók és a felnőttek válaszaiból viszont kiderült, hogy ezekben a korosztályokban már többen vannak (10-39\% között), akik a „valódi”-nak tekinthetö jelentéssel azonos szinonimát vagy körülírást adtak meg a kanapészörfre. A szövegkörnyezet támogató hatása (Tolcsvai Nagy 2010: 12) ezekben a válaszokban is kimutatható volt: az egyetemistáknak szövegkörnyezet nélkül 10 százaléka, szövegkörnyezetben 39 százaléka, a felnőtt adatközlőknek pedig szövegkörnyezet nélkül 19 százaléka, míg szövegkörnyezetben 26 százaléka értelmezte a „valódi” jelentésnek megfelelően a szót. Elözetes tapasztalataiknak tulajdonítható, hogy szövegkörnyezet nélkül is 10 százalékban, illetve 19 százalékban adtak meg olyan szinonimát vagy magyarázatot, mely megfeleltethető a szó prototipikusnak mondható jelentésének. Tekintetbe véve, hogy az általános és középiskolás diákok egyik kérdőív esetében sem adtak meg ilyen magyarázatot, úgy tünik, e szó esetében nagyon fontos volt, hogy találkozott-e már a nyelvhasználó korábban a neologizmussal, vagy nem. A bemutatott eredményeket a 17. ábra diagramja részletezi.

A kanapészörf felismertsége a kérdőív típusának függvényében (\%) - 2011

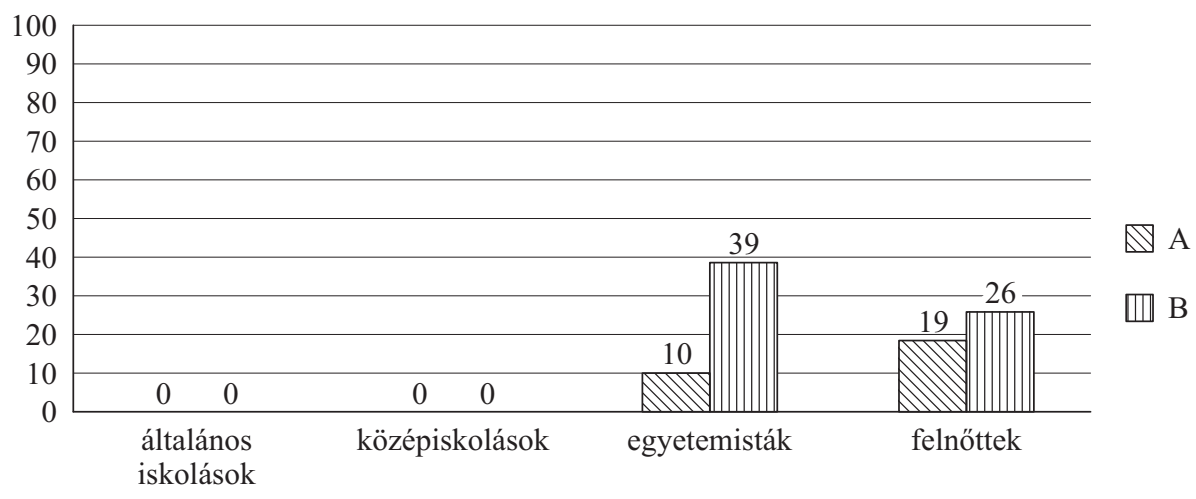

17. ábra: A kanapészörf felismertsége 2011-ben

A szó szemantikai jellemzőinek bemutatásához érdemes áttekinteni azokat a válaszokat, amelyeket a felmérésben részt vevő 180 adatközlő megadott a kanapészörf szinonimájaként vagy körülíró magyarázataként. Ismét hangsúlyozni kell, hogy ezekből a magyarázatokból a kérdőívet adott időben kitöltő, adott adatközlők jelentésképzési folyamataira következtethetünk.

Azok, akik a „valódi”-val megegyező magyarázatot adtak meg a szóval kapcsolatban, vagy a szó angol megfelelojjét ('couchsurfing') adták meg magyarázatként, vagy valamilyen módon megpróbálták körülírni a jelenség lényegét, például: 'hotel helyett magánszemély otthonában száll meg az utazó', 'kölcsönös csereüdülés', 'külföldiek, idegenek vendéglátása otthonunkban'.

A fenti válaszokból kiindulva a kanapészörf összetétel szemantikai szerkezete a Fauconnier-Turner-féle fogalmi integrációs modellben ismét eredményesen ábrázolha- 
tó. Mivel a szó összetétellel keletkezett, és ez a jellemzője a magyar nyelvủ alakban is jól észrevehetően profilálódik, feltételezhető, hogy az adatközlők a neologizmus értelmezésekor a két összetételi tag jelentését külön-külön is értelmezik a befogadás folyamatában, majd ezek együtteséből igyekeznek megadni az összetétel legvalószínűbbnek vélt jelentését. Ezt a feltételezett jelentéskonstruálási folyamatot alátámasztják azok az esetek is, melyekben az idézett kérdőívben az adatközlők nem a szó „valódi” jelentését adták meg akkor, amikor szinonimát vagy körülírást alkalmazhattak a szó jelentésének megmagyarázására, hanem a prototipikustól eltérő jelentést tulajdonítottak az alakulatnak. Néhányat érdemes ezekből a válaszokból is megvizsgálni. Minden korcsoport adatközlői ilyen jellegü - a „valódi” jelentéssel nem egyező - válaszukban a kanapé szó 'támlás, kárpitozott, fekvő- és ülőbútor' (ÉKsz. ${ }^{2} 2003: 617$ ) jelentéséből indultak ki, és jelentésmagyarázatukban vagy a bútor maga, vagy az ehhez metonimikusan kapcsolható valamilyen tevékenység (leggyakrabban a pihenés, kényelmes üldögélés vagy fekvés, néhány esetben pedig a szex) jelent meg. A szörf összetételi tag értelmezéséről elmondható, hogy az általános és középiskolás diákok válaszaiban - öt válasz kivételével - a fönév vagy a belöle képezhető szörfözik ige szó szerinti jelentése jelent meg, 'a tengerpart felé tartó hullám hátán való siklás; hullámlovaglás' (ÉKsz. ${ }^{2} 2003: 1284$ ) jelentésben. Ez a két korosztály a jelentésmagyarázataiban tehát a két összetételi tag szó szerinti jelentéséből indult ki, és egyszerüen a 'szörfölés a kanapén/kanapéval' meghatározással magyarázta a kanapészörföt, így sok esetben megjelent a 'kanapén állni és arra gondolni, hogy szörfölünk', 'szörfölés szimulálása a kanapén', 'tenger hullámain lovagolni egy kanapéval', 'ugrálás a kanapén' magyarázat. Abban az öt esetben, amikor nem a fentiekhez hasonló módon magyarázták a szó jelentését, négy esetben a 'netezés' (= 'internetezés') jelent meg 'az interneten keres(gél), böngész, tallóz' (ÉKsz. $\left.{ }^{2} 2003: 1284\right)$ jelentésben (hasonlóan az angol surf the net kifejezéshez).

A fogalmi integrációs elmélet keretében elemezve a kanapészörföt, az adatközlők által megadott jelentésmagyarázatok alapján kiindulhatunk abból, hogy az összetétel szemantikai szerkezetében a két összetételi tag jelentésének jut fontos szerep. A neológ alakulat esetében a kanapénak és a szörfnek első megközelítésben egy-egy jellemző funkciója profilálódik metonimikusan: FEKVÖHELY VENDÉG SZÁMÁRA, illetve SPORTESZKÖZ $\rightarrow$ HULLÁMLOVAGLÁs. Ezek a jellemző fogalmak még nem vezetnek el a kanapészörf jelentéséhez, viszont abban az esetben, ha egy-egy jellemző funkciójuk alapján ismét tovább szúkítjük őket metonimikusan, tehát a FEKVÖHELY VENDÉG SZÁMÁRA esetében az ÁTMENETI, INGYENES SZÁLLÁS EGY MÁSIK EMBER LAKÁSÁBAN fogalmára, a HULLÁMLOVAGLÁS esetében pedig a HELYVÁLTOZTATÁs fogalmára asszociálunk, akkor már megkapjuk a $\mathrm{ka}$ napészörfölés két fontos tulajdonságát: azt, hogy valaki egy magánlakásban vesz igénybe ingyenes szállást, nem pedig hogy állandó lakóhelyét változtatja. Ez pedig igaz a kanapészörf segítségével szállást kereső utazókra, turistákra. A generikus tér, amelynek jelenléte fakultatív, és mely olyan jellemzőkre, szerveződésekre reflektálna, amelyeket mindkét bemeneti tér birtokol (Fauconnier-Turner 1998a: 270), ebben az esetben nem jelenik meg, a két bemeneti tér által birtokolt jelentésszerkezetekben ugyanis nincsenek olyan közös tulajdonságok, melyek a generikus térbe kivetítődnének (ilyen típusú blendhez vö. Benczes 2010: 142, 146, 150 elemzéseit). Meg kell még említeni a szörf 
bemeneti terében egy érdekes módon „két irányban” müködő metafora jelenlétét is. Mivel a SZÖRFÖLÉs fogalma napjainkban nemcsak a vízi sportot, hanem a világhálón való szörfölést, böngészést is jelenti, ezt a tevékenységet is előhívja a neologizmus utótagja, utalva arra, hogy a kanapészörfösök az internet segítségével keresnek, illetve kínálnak szállást. Másfelöl pedig éppen az adatbázis-böngészés, a neten való szörfölés az, amely lehetővé teszi a helyváltoztatást (magát az utazást és a kanapészörfölést), így a metafora megjelenése lehetőséget ad arra, hogy a neologizmus jelentése magában hordozza a mozgás, helyváltoztatás fogalmát is.

A kanapészörf szemantikai szerkezete a fent leírtak alapján a fogalmi integrációs modellben a 18. ábrának megfelelö módon ábrázolható.

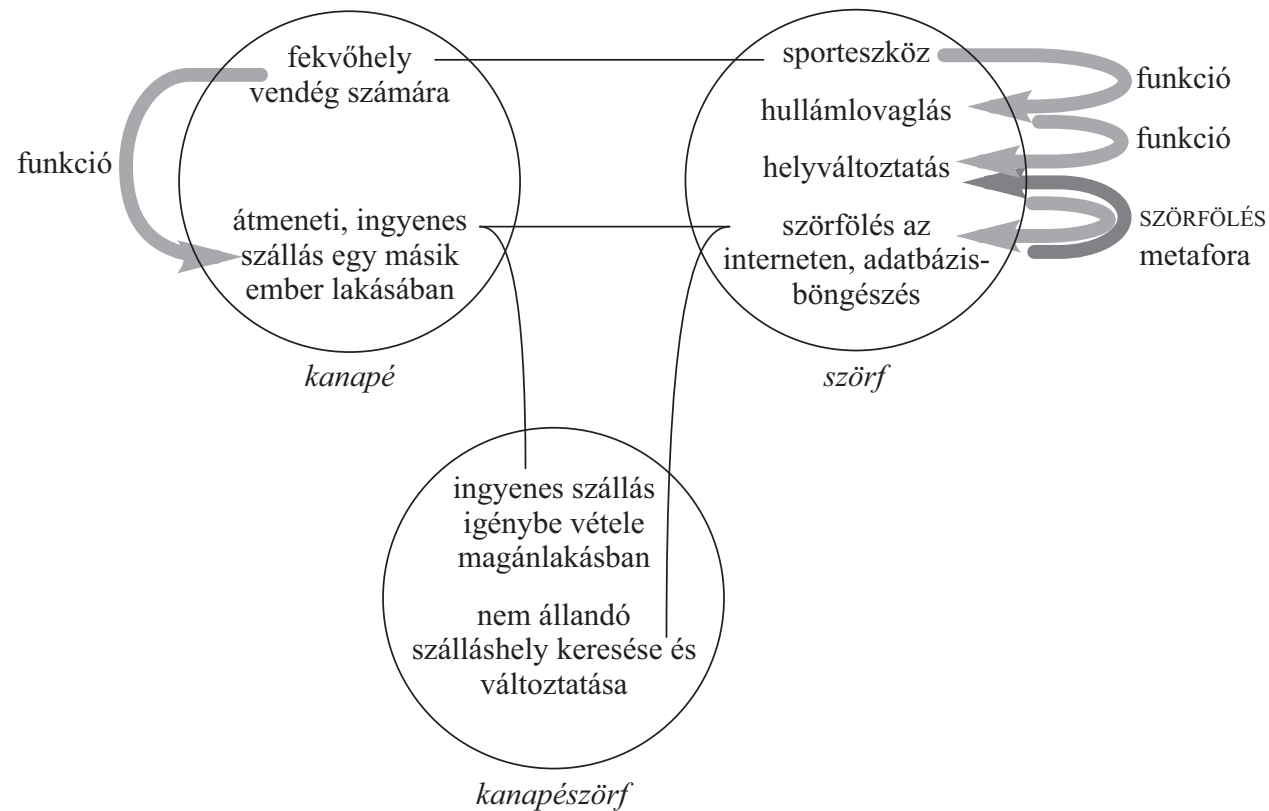

18. ábra: A kanapészörf ábrázolása blendként

\subsubsection{7. esettanulmány: passzívház}

A 'megújuló energia felhasználásával müködő, alacsony vagy zéró energiafogyasztású ház' jelentésű, a magyar nyelvben passzívház alakban megjelenő szó tükörfordítással keletkezett a német Passivhaus mintájára.

Az alábbiakban olvasható fórumszövegrészletben néhány évvel ezelött jelent meg ez a neologizmus. Mint a (28)-as szövegrészletből is kiderül, az írójának van már elözetes tapasztalata a passzívház szó jelentéséről, és kifejezetten olyanok véleményére kíváncsi, akiknek az ilyen típusú házak építésével kapcsolatban több tapasztalatuk van, mint neki (kiemelések tőlem - S. R.): 
szemi

Van valakinek tapasztalapta passzív ház építésével kapcsolatban, ilyen házban lakik, vagy közelről látott már ilyet?

Egyáltalán van realitása Magyarországon passzív ház építésében gondolkodni? ${ }^{14}$

A szó értelmezésére és gyakori félreértésére is jellemző a fenti idézetben is olvasható különírt változat, melyben a passzív előtag a ház jelzőjeként jelenik meg. Míg a német nyelvben 'forrás, behozatal' jelentésü is lehet a passiv szó (lásd például a NMNsz vonatkozó címszavát, illetve a Passivhandel, Passivseite szavak jelentését, NMNsz 1998: 1205), addig a magyar nyelvben az ÉKsz. ${ }^{2}$ jelentésmagyarázatai szerint a következő négy jelentésben jelenik meg: 1. 'tétlen, közömbös, részvétlen', 2. 'veszteséges', 3. 'szenvedö', 4. 'csak felületén oxidálódó <fém>' (ÉKsz. ${ }^{2} 2003$ : 1067).

A passzívház jelentésének kialakításában mindkét összetételi tag fontos szerepet tölt be. A neologizmus prototipikusnak tekinthetö jelentésében a passziv előtag által jelölt PASSZIVITÁs fogalom 'megújuló (energia)források' jelentésben jelenik meg. Amennyiben feltételezzük ilyen források jelenlétét, felhasználásukat vizsgálva logikus következtetésnek tünik, hogy a folyamat kisebb energiaszükségletet igényel, mint egyéb energiaforrások használata. Ez a metonimikus ok-okozati viszony teszi lehetővé, hogy a passzív előtag 'kisebb energiaszükségletü'-ként jelenjen meg az összetétel előtagjában. A PAszSZIVITÁs fogalmának ilyen jellegű megjelenése egyben egy fogalmi integrációként ábrázolható szemantikai szerkezet egyik bemeneti terét is alkotja. A blend másik bemeneti terében a HÁz fogalma mint élőlények számára szolgáló 'állandó lakóhelynek való épület' (ÉKsz. ${ }^{2}$ 2003: 505) jelenik meg; ez az entitás alkotja a másik bemeneti teret. Az integráció során a bemeneti tereknek a fent vázolt jellemzői profilálódnak, és az integrált térben együttesen képviselik a PASSzívHÁznak nevezett háztípusra jellemzö, ezt a háztípust a többi, HÁznak nevezett entitástól megkülönböztető tulajdonságokat.

A generikus tér megjelenése - a kanapészörf példájához hasonlóan - most sem szükséges, nincs ugyanis olyan közös jellemző a PASSzIVITÁs és a HÁz fogalmában, amely ebben a térben megjeleníthető lenne. Tény viszont, hogy a PAsszívHÁz fogalom értelmezése, a „valódi” jelentéshez való eljutás csak akkor lesz sikeres, ha a nyelvhasználó a PASSZIVITÁs fogalmának fent vázolt jelentését veszi figyelembe. A bemutatott szemantikai szerkezet a fogalmi integrációs modellben a 19. ábrának megfelelő módon ábrázolható.

Ennek a szónak az esetében is segíthet a befogadók által müködtetett értelmezési folyamatok feltárásában az, ha megvizsgáljuk, hogy a vonatkozó kérdőíves felmérések során az adatközlők milyen szinonimákat, jelentésmagyarázatokat adtak meg a szóval kapcsolatban. Szemantikai szempontból tanulságosnak bizonyulnak az adatközlőknek azok a válaszai is, amelyek nem hozhatók összefüggésbe a szó prototipikusnak tekinthető jelentésével; e válaszok segítségével ugyanis megfigyelhetők olyan, az adatközlők előzetes tudásából származó jellemzők a neologizmus jelentésmagyarázatának folyamatában, melyek következtében más asszociációs terek is aktiválódtak a szó értelmezésekor. 


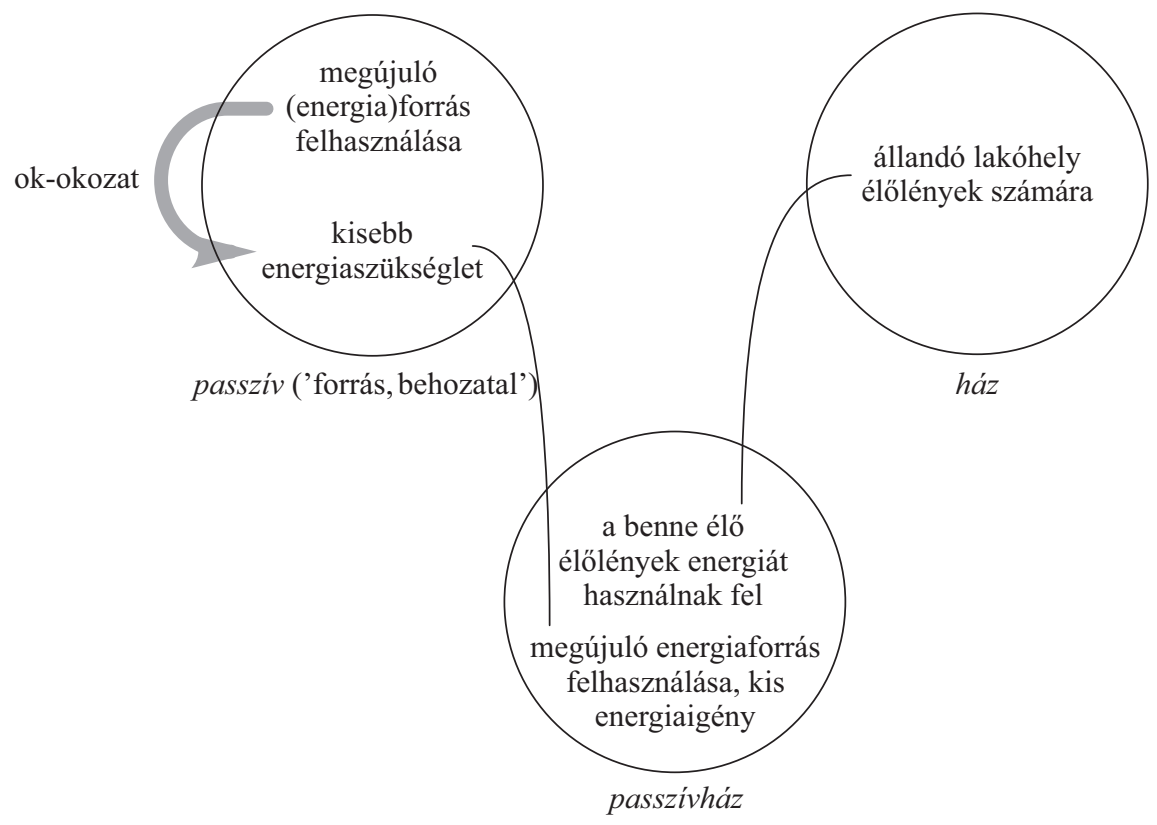

19. ábra: A passzívház ábrázolása blendként

A 2009 őszén és a 2011-ben felvett kérdöíves felmérésekben az adatközlők a következő arányban adtak meg a szó „,valódi” jelentésével megegyező magyarázatot a passzívházra:

A passzivház felismertsége a kérdőív típusának függvényében (\%) - 2009

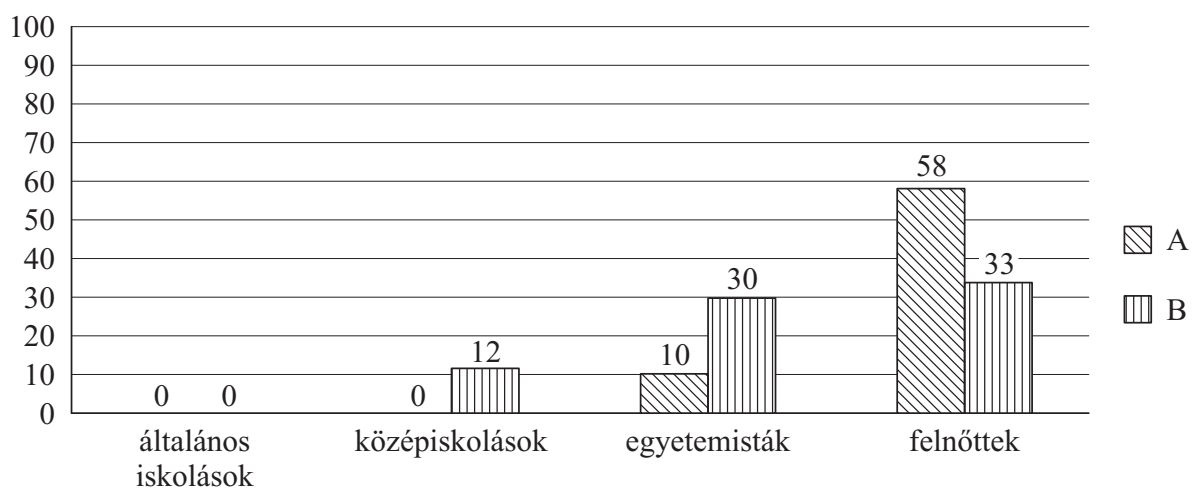

20. ábra: A passzivház felismertsége 2009-ben 
A passzivház felismertsége a kérdőív típusának függvényében (\%) - 2011

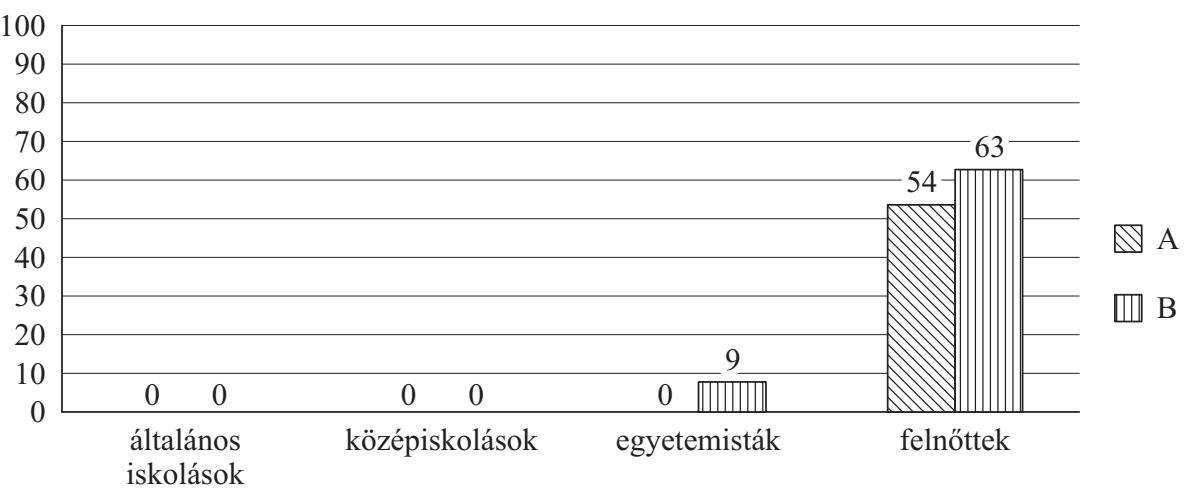

21. ábra: A passzívház felismertsége 2011-ben

A jelentésmagyarázatokban a passzívház szó grammatikai felépítése fontos szerepet játszik: a befogadók számára jól szegmentálható a szó, és a kapott javaslatokból kitünik, hogy a ház mint ismert és begyakorlott alakulat értelmezése nem ütközött akadályba egyik korosztály esetében sem. A HÁz entitás a jelentésmagyarázatok mindegyikében feltünt; a PAsszív előtag ezzel szemben igen különböző kereteket hívott elő az értelmezési folyamatban.

Mivel a PASSZIVITÁs fogalomnak a neologizmus szemantikai felépítését szervezö jelentésének ismeretével az adatközlőknek csak kis százaléka rendelkezett, a kérdőíves felmérésekben az előtagnak egyéb jelentéseit hívták elő, ezeket a jelentéseket próbálták aztán kapcsolatba hozni a ház utótaggal. A PASszIVITÁs értelmezésében szerepet játszó kapcsolatok jellemző módon metonimikus kiterjesztésként jelennek meg: a PASSZIVITÁs és így a passzívház feltételezett jelentése a következő lehet (zárójelben olvashatók az adatközlők javaslatai): 1. A HÁZBAN ÉLÖK ÁLLAPOTA A HÁZBAN ÉLŐK HELYÉN ('idősek otthona', 'otthon depressziós embereknek'), 2. A HÁZBAN ÉLŐK TEVÉKENYSÉGE A HÁZBAN ÉLÖK HELYÉN ('pihenőház', 'munkanélküliek háza', 'parlament' [sic!]), 3. AZ ÉPÜLET ÁLLAPOTA AZ ÁLLAPOT OKA HELYÉN ('olyan épület, ahol nem történik semmi','olyan irodaház, amelybe nem sikerül bérlőket találni'), 4. A LÉTREJÖvŐ ÁLLAPOT AZ ÉPÜLET FUNKCIÓJA HELYÉN (tipikusan valamilyen káros élvezeti szerről való leszoktatás helyszíneként: 'drogról leszoktató intézmény', 'olyan ház, ahol a cigiseket leszoktatják').

A passziv szó fent idézett jelentésének problematikusságán túl egy másik olyan jellemző, amely az általános iskolás korosztály értelmezésében jelent meg, a passzív és a masszív szavak fonológiai hasonlósága volt: ennek a korosztálynak feltehetően a PASSZIVITÁs fogalma is olyan mértékben absztraktnak és a HÁz fogalmához nehezen vagy egyáltalán nem kapcsolhatónak bizonyult, hogy több esetben a MAsszívsáG fogalmával próbálták meg összekapcsolni az előtagot. Így születtek ebben a korosztályban olyan értelmezések, mint 'kemény ház', 'jó szerkezetü ház', 'megerősített ház' stb.

Mint azt a fent bemutatott kérdőíves vizsgálatok vonatkozó eredményei is mutatják, a szójelentés felismerésének sikeressége a két vizsgálat között eltelt két évben egyál- 
talán nem nőtt, és valószínüsíthető, hogy csak azoknak az idősebb korú adatközlőknek az esetében müködött zavartalanul, akik korábbi tapasztalatokkal rendelkeztek a szó jelentéséről.

\subsubsection{8. esettanulmány: zöldbünözés}

A következő elemzendő összetett szó, a zöldbünözés szintén az angol nyelvböl került át tükörfordításként a magyarba. A zöldbünözés által meghatározott jelenségek évezredek óta jelen vannak a Földön; ezen a néven azonban az angol nyelvben csak az utóbbi évtizedekben kezdték nevezni, a magyarban pedig egészen új jelenségként, a jelen müben közölt munkadefiníció értelmében neologizmusként jelent meg az elmúlt években. A jelenségeket, melyeket a szó meghatároz, a köznyelvben összefoglalóan 'a természet elleni bünözés'-ként definiálhatjuk (a témával foglalkozó szakemberek természetesen ennél árnyaltabb módon osztályozzák az ebbe a kategóriába tartozó jelenségeket).

Az alábbi fórumszövegrészletben egy problémafelvetéssel (illegális szemétlerakás) kapcsolatban írt válasz szövegében jelenik meg a vizsgálandó neologizmus (kiemelés tőlem - S. R.):

green-eyed 2010. október 22. péntek, 19:07

Környezettudatos nevelés, szemléletformálás a helyi óvodákban és iskolákban, és véleményem szerint a felnőtt társadalom körében is. (...)

Zöld „Kommandó” bevezetése, aminek célja, hogy visszaszorítsák a zöldbünözést. ${ }^{15}$ (...)

Mivel a téma az idézett fórumon már adott volt, a fórumozóknak feltehetően megfelelő mennyiségủ előzetes tapasztalatuk és ismeretük volt ahhoz, hogy eredményesen bekapcsolódhassanak a diskurzusba. A zöldbünözés szemantikai felépítésének elemzése előtt ismét érdemes megemlíteni a 2011 nyarán felvett kérdőíves eredményeket. Ebben a kérdöívben a zöldbünözéssel kapcsolatban az adatközlök a 22. ábra diagramján látható arányban adtak meg a szó jelentésével megegyező jelentésmagyarázatot vagy szinonimákat.

A 22. ábra alapján elmondható, hogy a szó felismertsége az életkorral párhuzamosan nőtt; kivételt ez alól az általános iskolás (7-8. osztályos) diákoknak azok a válaszai képeznek, amelyeket szövegkörnyezet nélkül, tehát az „A” típusú kérdőívek esetében adtak meg: itt ugyanis a prototipikusnak mondható jelentéssel megegyező válaszok aránya kiugróan magas, eléri a 48 százalékot. A magas arány okára magyarázatot adhat az a tény, amelyről a diákok tanárai tájékoztattak: iskolájukban rendszeresen szerveznek ,zöld” programokat, ezek része a természetjárás, szemétszedés, parkositási munkák és tájékoztató elöadások meghallgatása, így a diákoknak pontos ismereteik vannak a zöld fogalomnak a környezetvédelemhez és -tudatossághoz kapcsolódó (metonimikus) jelentéséről.

15 Forrás: http://www.peceli.hu/index.php/hirek/helyi-hirek/96-normal-helyi/3921-illegalis-szemetpecelen (letöltés ideje: 2011. augusztus 4.). 
A zöldbünözés felismertsége a kérdőív típusának függvényében (\%) - 2011

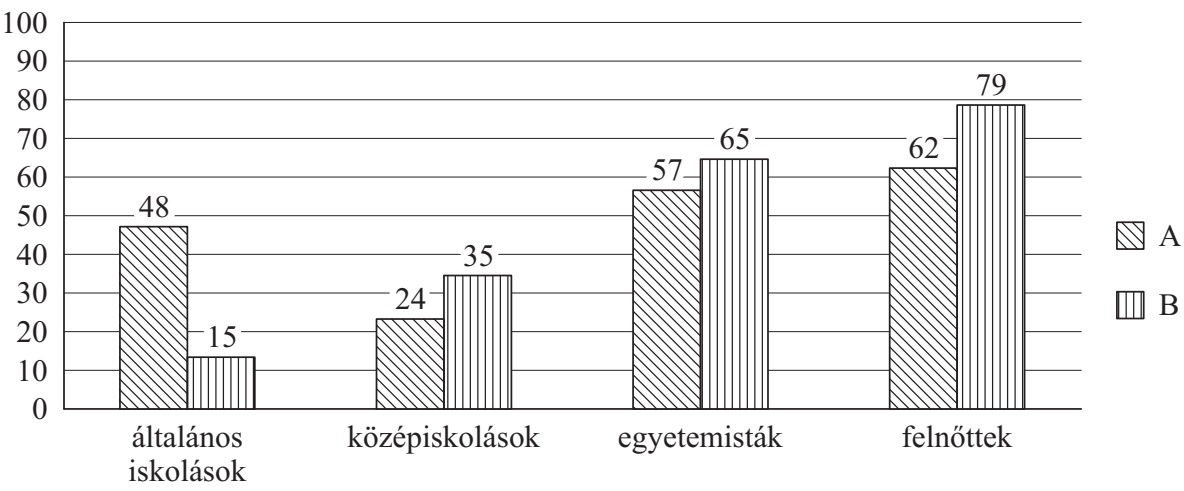

22. ábra: A zöldbünözés felismertsége 2011-ben

Azok között a magyarázatok, szinonimák között, melyek nem a „,valódi”'nak tekinthető jelentését adták meg a szónak, olyan kategóriák rajzolódnak ki, melyekre sok esetben asszociáltak az adatközlők, s melyekhez a zöLD fogalom mint forrástartomány segítségével más elérési útvonalon keresztül juthat el a befogadó. Ezek között a fogalmak között gyakran megjelent a 'drogkereskedelem', 'drogozás', 'kábítószerezés' magyarázat, mivel az adatközlők a kábítószer alapanyagának színeként asszociáltak metonimikusan a zöld elötagra (hasonlóan, mint ahogyan a tea levelének és a marihuánának az összefüggésére utal Dirven 2003: 81). A bünözés mint cselekvés pedig logikusan összekapcsolható volt az adatközlők számára a kábítószer-fogyasztással vagy -kereskedelemmel. A másik jellemző, de a ,valódi” jelentéssel nem azonos magyarázat a zöld színnek a 'szabad jelzés' jelentéséhez kapcsolódott (magyarázatok a zöldbünözésre: 'engedett bünözés', 'még nem annyira súlyos bünözés', 'szabad utat kap a bünözés'). Néhány alkalommal megjelent a zöLD fogalmának metonimikus kiterjesztése a zöldhatár fogalmára, és így a neologizmus jelentését 'zöldhatáron történő átszökés'-ként értelmezték az adatközlök.

A zöldbünözés szemantikai elemzésekor célszerü a melléknévi előtag megjelenésének okaiból, adekvátságából kiindulni; a fent részletezett válaszokban is megfigyelhető volt, hogy az adatközlők figyelmét az összetételben különösen a zöLD fogalmának lehetséges értelmezése irányította a jelentésmagyarázatok és szinonimák megadásakor. Benczes Sweetser (1999) megállapítása alapján felhívja a figyelmet arra, hogy a melléknév-fönév és a főnév-főnév felépítésü összetételek esetében az elemzés csak akkor lehet teljes, ha nemcsak a metaforikus és metonimikus jelentésviszonyokat, illetve a fogalmi integráció elméletét, hanem további jelentésszervező mechanizmusokat is alkalmazunk. Ilyen elvek lehetnek ,a keretek, az aktív zóna, a profilálás és a konstruálás” (Benczes 2006: 64). A zöldbünözés összetételben is egy szín alkotja a melléknévi előtagot, viszont ennek az összetételnek az esetében a ZÖLD és a TERMÉSZET közötti viszonyban a RÉSZ AZ EGÉSZ HELYÉN metonímia emelődik ki, ez ugyanis a TERMÉSZET fogalmának egy olyan jellemző tulajdonsága, melyről a legtöbb nyelvhasználónak feltehetően vannak elözetes ismeretei, tapasztalatai. Ez a tulajdonság (a növényvilág színe) tehát egyfajta keretként mükö- 
dik a neológ összetételben, melynek elérési útvonala meglehetősen rövid lehet, hiszen a nyelvhasználók ismerhetnek már más, régebbi keletkezésü, begyakorlottabb alakulatokat ebben a témakörben, melyekben szintén metonimikusan, már a MÓD AZ EREDMÉNY HELYÉN jelenik meg a zöld színnév (például zöldaktivista, zöldtechnológia). A jelentés ily módon könnyen hozzáférhetővé válik a nyelvhasználók számára.

A fent említett begyakorlottságnak és a mögötte meghúzódó tudáskeret jelentősége kap hangsúlyt mind az elö-, mind az utótag értelmezésében akkor, amikor a neologizmus szemantikai szerkezetét vizsgáljuk. Ezt a zöldbünözés esetében is érdemes a fogalmi integrációs elmélet keretében megtenni, így ugyanis kiemelhetők azok az aspektusok, amelyek a jelentésképzés folyamatában a jelentés szervezésében részt vesznek. Az egyik bemeneti térben a zöld előtag jelenik meg, melyből kétszeres metonimikus leszükítés eredményeképpen jutunk el a természet fogalmához: a szín egyrészt mint jellemző tulajdonság profilálódik, és utal a természetben megtalálható növényekre (és feltételezhetően más élőlényekre is, melyek életfeltételét jelenti a zöld növényzet), majd az így asszociált növényzet utal metonimikusan az egészre, magára a természetre. A zöld elötag tehát ez esetben 'természethez kapcsolódó' jellemzőként jelenik meg a neologizmusban. A másik bemeneti térben a bünözés fogalma és a hozzá kapcsolódó kulturális és szociális ismeretek, tapasztalatok jelennek meg; ezt a teret tehát végső soron a bünözéshez kapcsolódó tudáskeret szervezi. Ennek meglehetősen állandó résztvevőket és cselekményeket tartalmazó, a befogadók számára jól ismert forgatókönyve van, mely tartalmazza az elkövetö, az elkövetés és az áldozat entitásokat. Az ezek által a bemeneti terek által szervezett blendnek az az érdekessége, hogy az egyik bemeneti térben csak az áldozat (az elszenvedő patiens) jelenik meg, míg a másik az ágenst, a cselekvést és az áldozatot is tartalmazza. Míg a generikus térben a valaki vagy valami ellen elkövetett bün általános forgatókönyve jelenik meg, addig az első bemeneti tér aktualizálja és pontosítja az áldozatot, vagyis egyértelművé teszi, hogy a természet elleni bünözésről van szó; az integrált térben így már ez az aspektus jelenik meg a 23. ábrán látható módon.

A fentiek és a 23. ábra alapján elmondható, hogy a zöldbünözés esetében olyan neologizmusról van szó, amelynek szemantikai szerkezete - a vonatkozó kérdőíves felmérések tanulságai szerint is - kellően transzparens ahhoz, hogy a nyelvhasználók a diskurzus során a befogadás folyamatában könnyen átlássák, és így megértsék az összetett szó jelentését. Mint azonban a 23. ábra bemeneti tereiben is látható, a megértésben akadályt a zöld elötaghoz kapcsolódó metonimikus folyamatok, illetve a 'természethez kapcsolódó entitás'-nak mint áldozatnak a felismerése jelenthet; ezek értelmezéséhez ugyanis nagyobb mentális erőfeszítés árán juthatnak hozzá a nyelvhasználók, mint a jól begyakorlott utótag, a bünözés (a hozzá kapcsolódó forgatókönyv implikálta) jelentéséhez.

\subsubsection{9. esettanulmány: bagolyvonat}

A bagolyvonat szóösszetétel az elmúlt években jelent meg a magyar nyelvben. A szóval azokat a vonatjáratokat nevezik meg, melyek nyáron, éjszakánként (és elsősorban hétvégente) járnak olyan útvonalakon, ahol sok turista, illetve a szórakozóhelyek közönsége 


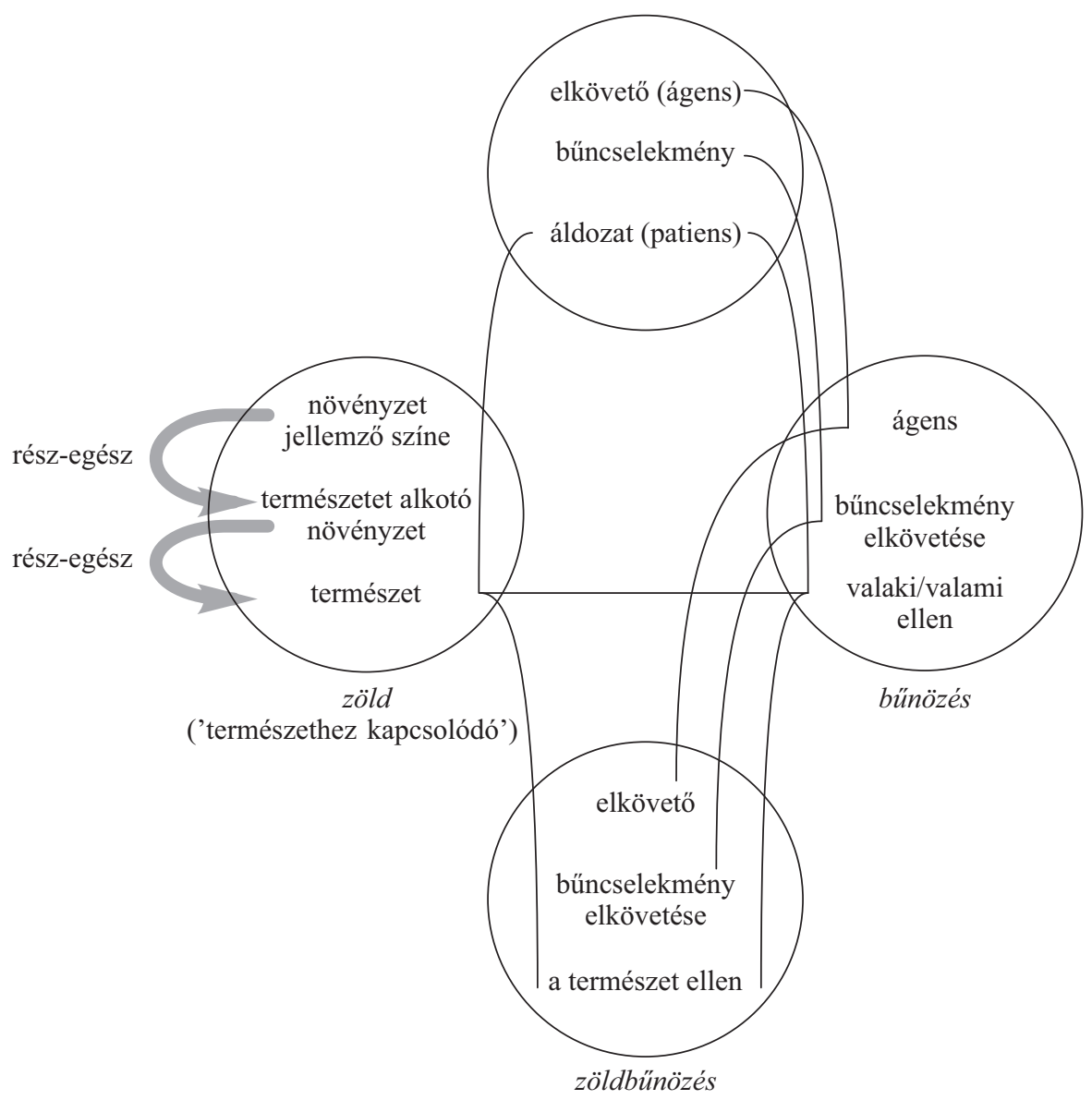

23. ábra: A zöldbünözés ábrázolása blendként

közlekedik. A szó a magyarban ezeknek a vonatjáratoknak a bevezetésével jelent meg, és a jelen müben használt munkadefiníció értelmében neologizmusnak tekinthető. Jelentését 'a nyári menetrend idején hétvégenként éjszaka közlekedő vonatjárat'-ként lehet megadni.

A bagolyvonat szóösszetétellel kapcsolatban rögtön feltünik, hogy - a zöldbünözéshez hasonlóan - ismét olyan neologizmusról van szó, amelynek egyik összetételi tagja, a vonat szó szerinti jelentésében szerepel az alakulatban; a bagoly előtag viszont már összetettebb jelentésében, és így szemantikai szerkezete árnyaltabb elemzést igényel a megértés folyamatában (a bagoly szemantikai szerkezetének összetettségével kapcsolatban lásd Sólyom 2009c: 262). Jellemző, hogy a Google keresőprogramban a korábbi keletkezésủ találatok között akad olyan, amelynek az esetében még idézőjelben („,bagolyvonat"-ként) utalnak ezekre a járatokra. A későbbi keletkezésủ szövegekben viszont már eltünik az idézőjel - ez a jelenség a neologizmus meggyökeresedésére vagy legalábbis a nyelvhasználóknak erre a szándékára utalhat. 
A (30)-as számú szövegrészlet válasz a fórumozók törekvésére, hogy szállást találjanak egy nagyobb baráti társaságnak. A szállásjavaslatokra reagálva tünik fel az egyik hozzászólásban a bagolyvonat (kiemelés tőlem - S. R.):

(30)

(C) puluty 2006. júl. 24. 16:00

Gerinek nem kell szállás, Tipliéknek sem. Kukkót most kérdezem. Pinnyó éjjel megy haza a bagolyvonattal. ${ }^{16}$

A fenti szövegrészletben megfigyelhetők az informális nyelvhasználat jellemzői (például a fórumozók nickneveinek vagy becéző neveknek a használata, határozott névelö használata tulajdonnév előtt), amiből arra következtethetünk, hogy a közlő és a befogadó jól ismeri egymást, sőt, valószínúleg baráti viszonyban vannak egymással. Minden bizonnyal nem ez az első szabadidős program, amelyet közösen szerveznek, így a szállásfoglalással és az utazással kapcsolatban is rendelkezhetnek előzetes tapasztalatokkal. Ez feltehetően igaz a bagolyvonat értelmezésének és használatának esetében is, hiszen a neologizmus különösebb magyarázat vagy kiegészítő információk nélkül jelenik meg a hozzászólás szövegében (a vizsgált szót tartalmazó mondatban mindössze egy megértést segítő utalás van az utazás időpontjára: ,éjjel megy haza”). A bagolyvonat a 2011 nyarán felvett kérdőíves vizsgálódásomban szerepelt.

A szó felismertségével kapcsolatban azokat a válaszokat tekintettem a neologizmus „valódi” jelentésével megegyezőnek, melyekben a következő jellemző tulajdonságok szerepeltek: a bagolyvonat 1. vonat(járat), 2. éjszaka közlekedik. A bagolyvonatnak azt a jellemzőjét, hogy fóként szórakozóhelyek látogatóit, bulizó fiatalokat szállít, nem vettem be a kritériumok közé, ugyanis a bagolyvonattal nemcsak a bulizók és nemcsak fiatalok, hanem más okból éjszaka úton levők is utazhatnak.

A vizsgált neologizmus felismertsége a fenti kritériumok alapján a 24. ábrán látható módon alakult.

A bagolyvonat esetében megfigyelhető volt a szó felismertségének növekedése az életkor növekedésével: a bagoly előtag metaforikus használatát - melyet az ÉKsz. ${ }^{2}$ tréfás vagy gúnyos stílusminősítéssel közölt magyarázata alapján, mely az éjjeli bagolyra vonatkozik ('aki szeret éjszakázni, virrasztani', ÉKsz. ${ }^{2} 2003$ : 81), 'éjszaka fent levő és aktívan tevékenykedő ember'-ként határozhatjuk meg - az életkor növekedésével egyre nagyobb arányban ismerték fel az adatközlők. Azokban a jelentésmagyarázatokban, amelyekben az előtagnak nem a metaforikus jelentését adták meg az adatközlők, az általános és középiskolás korosztály rendszerint a bagoly szó szerinti jelentését vette figyelembe, így például a következő szinonimákat és magyarázatokat írták: 'baglyokat szállító vonat', 'baglyok repülnek egymás után', 'olyan vagon, ahol baglyok vannak'. Más esetben az előtaghoz kapcsolódóan vagy valamilyen más metaforikus és/vagy metonimikus asszociációt tartalmazó magyarázatot adtak meg az adatközlők (ez mind a négy kor-

16 Forrás: http://sgforum.hu/listazas.php3?id=1145950974\&order=reverse\&index=2\&azonosito=vaszolynapok (letöltés ideje: 2011. október 27.). 
A bagolyvonat felismertsége a kérdőív típusának függvényében (\%) - 2011

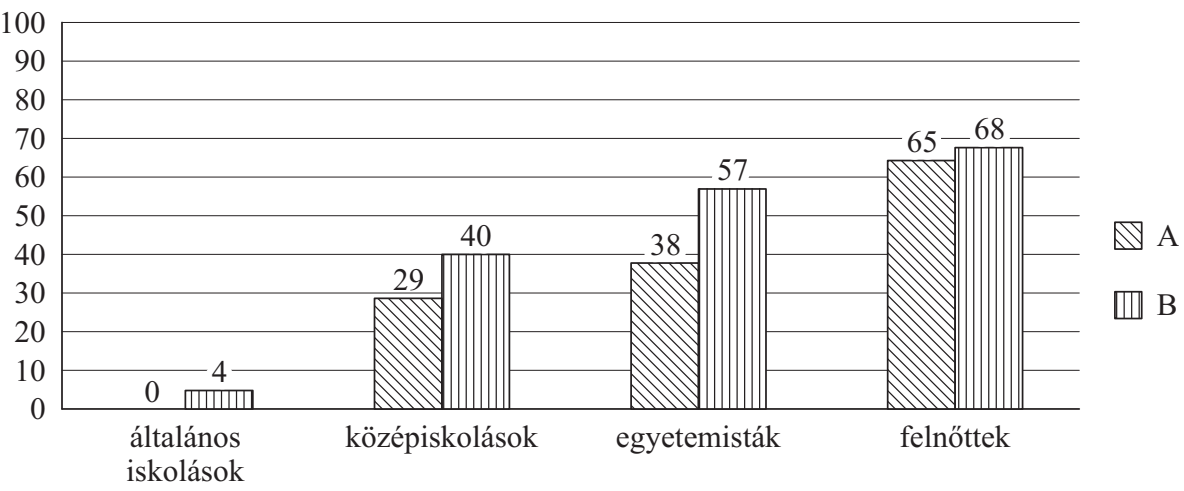

24. ábra: A bagolyvonat felismertsége 2011-ben

csoport esetében megfigyelhető volt), például: 'alvászavarral küzdők járata' (a BAGOLY az éjszakai nem alváshoz kapcsolódik), 'könyvtárklub' (a BAGOLY az olvasás és a könyvek megjelenítője), 'levélszállító autó' (a BAGOLY a postai szolgáltatások megjelenítője) 'okos gyerekeket szállító vonat', 'okostojás' (a két utolsó példánál a BAGOLY a tudás megjelenítője). Ezeknek a jelentésmagyarázatoknak a részletes szemantikai elemzésére a jelen munkanem tér ki, jelenlétük ugyanakkor rendkívül fontos, hiszen rávilágíthatnak a szó esetleges félreértéséhez vezető értelmezési stratégiákra is, másfelől pedig hozzásegíthetnek a neologizmus szemantikai szerkezetének eredményesebb feltárásához.

A bagolyvonat összetett szóban az utótag (a vonat) szó szerinti jelentésében szerepel, tehát az ÉKsz. ${ }^{2}$ meghatározásai közül ('mozdonnyal vontatott vasúti kocsik sora, esetleg motorkocsi. Menetrend szerint közlekedő vasúti járat.', ÉKsz. ${ }^{2} 2003$ : 1483) a neologizmus esetében a második, a 'menetrend szerint közlekedő vasúti járat' jelentésű érvényesül. A neologizmus szemantikai felépítésének érdekességét az előtag, a bagoly szó megjelenése adja. Azon túl ugyanis, hogy a befogadó számára az EMBER ÁLLAT fogalmi metaforán alapuló azonosítás előhívhatja a bagoly szó itteni jelentését ('éjszakázó, éjszaka aktív ember'), a metafora jelenléte még nem vezet el egyértelműen a bagolyvonat alakulat értelmezéséhez. A bagoly metaforának ugyanis egy jellemző tulajdonsága emelödik ki metonimikusan: az éjszaka tevékenykedő ember tevékenységéből a tevékenység ideje kap különös jelentőséget az összetett szó előtagjában. Ez a fajta kiemelődés egyben példa a Langacker által aktív zónának nevezett metonimikus kiemelésre (idézi Benczes 2006: 64-66; Kövecses-Benczes 2010: 66): a bagolyként megnevezett, éjszaka tevékenykedő ember tevékenységének folyamatából a keletkező neologizmus szempontjából leginkább releváns tulajdonság, az éjszakai idő emelődik ki. Az előtag tehát - mely egy, a magyar kultúrában elfogadott és régóta meglévő metafora - a bagolyvonat alakulat esetében éppen a metonimikus kiemelés miatt úgy utal a vonatjárat közlekedési idejére, hogy közben - éppen a meglévő kulturális tudásnak köszönhetően - a vonat által szállított utasokra is asszociálhat a befogadó. 
Amennyiben a bagolyvonat összetételt a fogalmi integrációs elmélet keretében elemezzük, generikus tér nem jelenik meg, ugyanis a két összetételi tag jelentésének külön-külön nincsenek olyan aspektusai, melyek együttesen jelennének meg egy generikus térben. Az alakulat előtagjának szemantikai szerkezete (a fent részletezett módon) különösen összetett felépítésű, míg az utótag szó szerinti jelentésben jelenik meg. A köztük levő megfelelések, melyek a jelentés konstruálásának folyamatában részt vesznek, az éjszaka aktív ember és a személyeket, utasokat szállító vonat, illetve a TEVÉKENYSÉG IDEJE metonímia és a vonat közlekedésének ideje között van. Ezeknek a megfeleléseknek a segítségével képeződnek le a neologizmus ,valódi” jelentésében megjelenő tulajdonságok, tehát a következők: a bagolyvonat az éjszaka közlekedő, (ha nem is feltétlenül az utazás pillanatában, de) éjjel aktív utasokat szállító, menetrend szerinti vonatjárat.

A fent leírtaknak megfelelően a bagolyvonat szemantikai szerkezete a fogalmi integráció keretében a 25. ábrán látható módon ábrázolható.

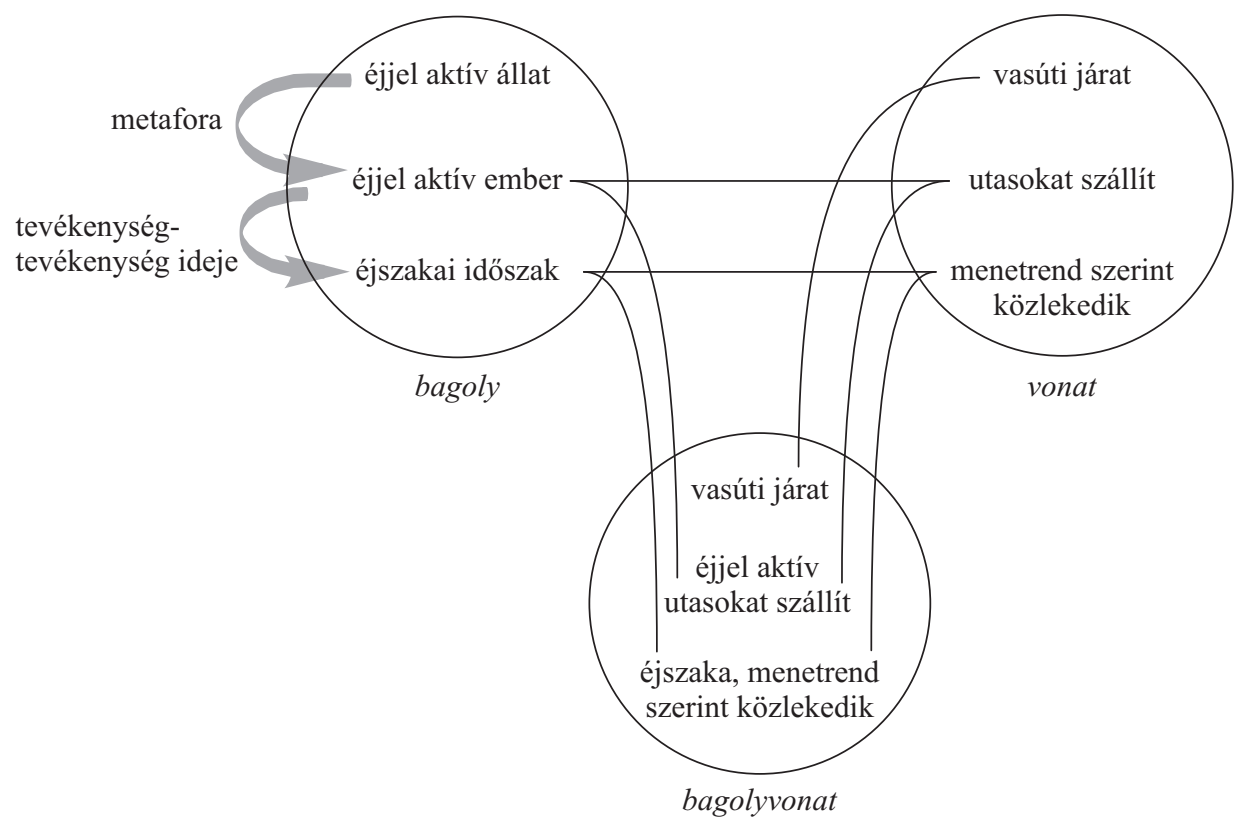

25. ábra: A bagolyvonat ábrázolása blendként

A neologizmus jelentését jellemző összetett szemantikai tulajdonságokat áttekintve érthetőnek tűnik az adatközlők által megadott „téves” jelentésmagyarázatok jellege és viszonylag nagy száma is. Másrészt viszont meg kell jegyezni, hogy nagy jelentősége volt a neologizmus jelentésének azonosításában az adatközlők előzetes tapasztalatainak, ezek pedig a felmérésben kapott adatok alapján feltehetően az életkor növekedésével egyenes arányban nőttek. 


\subsubsection{0. esettanulmány: kormányablak}

A következő elemzendő neologizmus, a kormányablak az előző példákhoz hasonlóan szóösszetétellel keletkezett. Ennek a szónak a megjelenése konkrét időponthoz köthető: 2011. január 3-án kezdték meg müködésüket a kormányhivatalokban a kormányablaknak nevezett ügyfélszolgálatok, ,,amelyek feladata a területi közigazgatási ügyek intézésének egyszerüsítése" (hvg.hu, 2010. 12. 23.). ${ }^{17}$

A kormányablak mindkét összetételi tagja magyar szó; ez a megállapítás azért lehet fontos, mert a jelentés szervezésének folyamatában fontos szerepet betöltő elő- és utótagnak a magyar nyelvben több, egymástól gyakran jelentős mértékben különböző jelentései léteznek; ezekre a kérdőíves felmérésben kapott szinonimajavaslatoknál fogok hivatkozni.

Ezzel a neologizmussal kapcsolatban a 2011-es kérdőíves vizsgálódásban megfigyelhető volt, hogy azok, akik találkoztak már 2011 májusáig-júniusáig a szóval, pontosan leírták a jelentését, akik viszont még nem, nem tudták kitalálni, mit jelenthet. Mint az a 26. ábra diagramján is látható, az általános és a középiskolás korcsoportban egy olyan jelentésmagyarázat vagy szinonima sem született, amely megegyezett volna a neologizmus „valódi” jelentésével. Jelentősebb növekedés a szó felismerésében csak a felnőtt adatközlök között volt tapasztalható.

A kormányablak felismertsége a kérdőív típusának függvényében (\%) - 2011

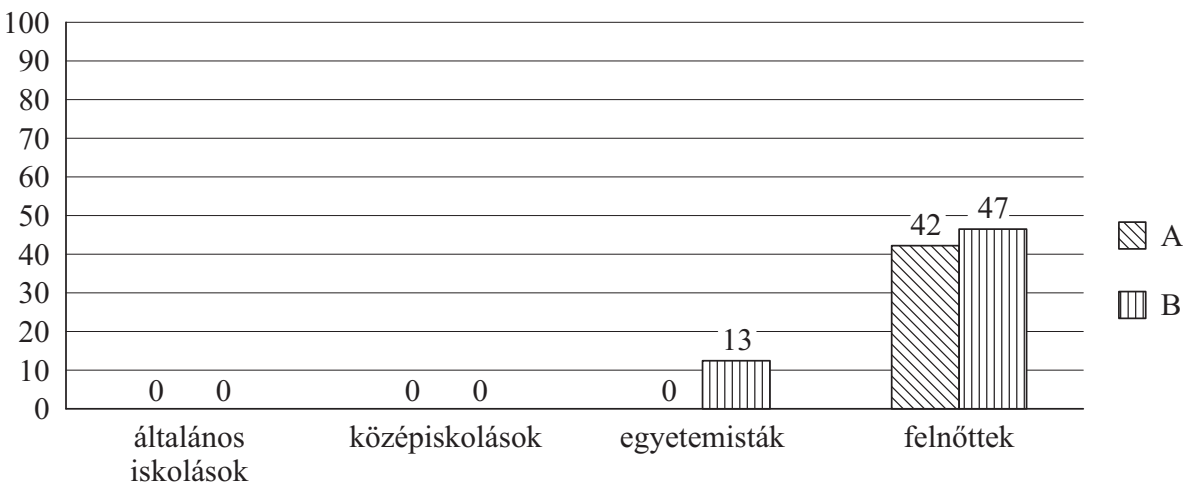

26. ábra: A kormányablak felismertsége 2011-ben

A kormányablak esetében a felismertség fent látható alacsony arányához feltehetően nemcsak az előzetes tapasztalatok hiánya, hanem a szó szemantikai szerkezete is hozzájárult: az összetételi tagok poliszémiájának, illetve a közöttük fellelhető szemantikai kapcsolatoknak köszönhetően a jelentéskonstruálás folyamatában a neologizmus értel-

17 Forrás: http://hvg.hu/itthon/20101223_kormanyablak_kormanyhivatalok_(letöltés ideje: 2011. március 10.). 
mezéséhez a nyelvhasználóknak feltehetően előzetes ismeretekre van szükségük (legalább az összetételi tagok poliszém jelentéseivel kapcsolatban).

Mint ahogyan annak a fórumozónak a bejegyzése is a korábban szerzett tapasztalatokról tanúskodik, aki egy, a kormányablakokkal kapcsolatos topicra reagált hozzászólásában a következőképpen (kiemelés tőlem - S. R.):

ez meg az

2011. 07. 14. 16:34:55

Kormányablak, jó nagy parasztvakítás. Lassú, mint az állat és onnan is elküldik az embert szana-szét a beszerzendő okmányokért. Annyi, hogy most a rendszer úgymond, sugaras. Most egy helyröl küldözgetnek mindenhová. $(\ldots)^{18}$

A kormányablak szemantikai szerkezetének vizsgálatában véleményem szerint ismét segítséget nyújthat, ha megvizsgáljuk a kérdőíves felmérésben azokat a szómagyarázatokat, amelyeket az adatközlők a szóval kapcsolatban írtak. Közülük is különösen hasznosak azok, amelyek nem egyeznek meg a neologizmus „valódi” jelentésével. Ezekből a magyarázatokból, szinonimákból következtethetünk arra, hogy a szót olvasva az öszszetételnek (és az azt alkotó tagoknak) milyen jelentései profilálódtak a nyelvhasználók számára.

Az adatközlők egy része az előtag esetében a kormány szónak 'az államhatalom központi végrehajtó szerve, rendszerint a miniszterek testülete' (ÉKsz. ${ }^{2} 2003:$ 736) jelentését próbálta bevonni a magyarázatába, de az összetett szó jelentését nem tudta kikövetkeztetni. Ilyen magyarázat volt például 'a Parlament ablaka', melyben a kormány előtag megjelenéséből a HELY AZ OTT DOLGOZÓK HELYÉN fogalmi metonímia alapján a kormány tartózkodási helyére, a Parlamentre következtetett az adatközlö; az ablak szót viszont szó szerinti jelentésében értelmezte. A megadott válaszok között sok esetben megjelent az ablak szónak a metaforikus értelmezése ('betekintés valahová' vagy az 'interneten megjelenő felület' jelentésben). Ilyen magyarázatok voltak például az 'internetes portál, melyen elérhetők a kormány tagjai', a 'betekintés a kormányzat ügyeibe'. Az életkor csökkenésével egyre nagyobb mértékben jelentek meg olyan meghatározások, amelyek az ablak szónak nem a metaforikus, hanem a szó szerinti jelentéseihez kapcsolódtak. Így jelent meg egyre többször a 'ház ablaka', valamint a kormány szó másik jelentésének ('az a szerkezet, amellyel némely jármű menetirányát szabályozzák.', ÉKsz. ${ }^{2} 2003:$ 736) értelmében az 'autó ablaka' értelmezés. Ennek értelmében a kormányablak magyarázataiként a következőkkel találkoztam: 'első szélvédő az autóban', 'a soför oldalán lévő ablak', 'olyan ablak, amit úgy nyitnak ki, mintha autókormány lenne' (sic!).

A fenti jelentésmagyarázatok, bár nem azonosak a szó „valódi” jelentésével, rávilágíthatnak arra, hogy milyen mentális folyamatok révén igyekeznek a nyelvhasználók értelmezni a neologizmust, így egyúttal a jelentésképzés folyamatának modellálására is jó lehetőséget nyújtanak. Amennyiben az összetételi tagoknak a neologizmusban meg-

18 Forrás: $\mathrm{http}: / /$ forum.index.hu/Article/showArticle?na start=0\&na_step=30\&t=9209430\&na order= (letöltés ideje: 2011. augusztus 19.). 
jelenő jelentéseit és azok jellemző szemantikai összetevőit vesszük figyelembe, eredményesen feltárható az összetétel jelentésszerkezete. A szemantikai szerkezet ábrázolása a fogalmi integráció segítségével egyszersmind feltárhatja, milyen akadályokba ütközhet a szó megértése, tehát általánosságban véve a jelentéskonstruálás folyamata.

A kormányablakok a kormányhivatalokban találhatók. A hivatal elnevezésének megfelelően az ott található ügyfélszolgálati pult megnevezésében is a kormány előtag jelent meg, metonimikusan utalva az ügyintézési hely felügyeleti szervére, arra tehát, hogy Magyarország kormánya által felügyelt hivatali helyről van szó. Az ország kormánya és a kormányhivatal között a felügyeleti szerv - felügyelt hivatal metonimikus viszony áll fenn, mely tágabban a FELÜGYELÖ-FELÜGYELT fogalmi metonímián alapul. A kormányhivatalokban sokféle ügyet lehet intézni (köztük azokat is, melyek intézésére a kormányablak létrejött), így a hivatal és a hivatalban intézett ügyek között is metonimikus viszony (HELY - AZ OTT INTÉZETT ÜGYEK) mutatható ki. A neologizmus előtagjáról, a kormány szóról tehát véleményem szerint elmondható, hogy megjelenésével a 'kormányhivatalokban intézett ügyek'-re utal. Mindez a fent leírt módon kettős metonimikus leképezéssel valósul meg; az összetételben a kormány előtag tehát a Langacker (1987) által aktív zónaként (idézi Benczes 2006: 64-66; Kövecses-Benczes 2010: 66) jellemzett folyamat értelmében jelenik meg.

Az összetett szó utótagja, az ablak szó az ügyfélszolgálatokon fizikai valójában is jelen van, az ÉKsz. ${ }^{2}$ meghatározása értelmében 'épületen, jármüvön a világosság és a levegö bebocsátására való (zárható) nyílás' jelentésben (ÉKsz. ${ }^{2}$ 2003: 1), de funkciója a kormányhivatalokban elsősorban nem a világosság vagy a levegő bebocsátása, hanem az, hogy az ügyfél és az ügyintéző kommunikációját a fizikai térben lehetővé tegye. A hivatali ügyintézés során az ügyfeleket kiszolgáló pultokat ilyen módon ablaknak szokták nevezni (ezek általában fizikai valójukban, kinézetükben is ablakszerúek). Az ablak szó megjelenése fizikai entitásra utal, a neologizmus esetében azonban ennek az entitásnak az absztrakt funkciójára, az ügyfélszolgálat tevékenységére vonatkozik metonimikusan, tehát arra a helyre és funkcióra, amelynek a segítségével az ügyfél az ügyeket intézni tudja. Az összetett szó kormány előtagja és az általa felidézett asszociációk (ügyintézés) is segíthetik a nyelvhasználót abban, hogy az ablak utótag esetében is az ügyintézés fogalmára asszociáljon. A fogalmi integráció során létrejövő generikus térben e tényezők segítségével felidézödhet az ügyintézési folyamat forgatókönyve, melyben megjelenik a felügyeleti szerv, maga az ügyintézés aktusa, illetve a benne részt vevő szereplők, az ügyintéző és az ügyfél.

Az integrált térben megjelenő jelentéshez ('a kormány által felügyelt kormányhivatalok hatáskörébe tartozó ügyek intézésére szolgáló ügyfélszolgálat') a bemeneti terekben fellelhető asszociációk nem azonos módon, tehát aszimmetrikusan járulnak hozzá. Az előtag által létrehozott bemeneti térből a felügyeleti szerv és az ügyintézés fogalmai, míg az utótag által strukturált bemeneti térből az ügyintézés és az ügyfélszolgálat fogalmak járulnak hozzá a neologizmus jelentésének kialakításához.

A fent elmondottak a fogalmi integrációs elméletben a 27. ábrán látható módon ábrázolhatók blendként. 


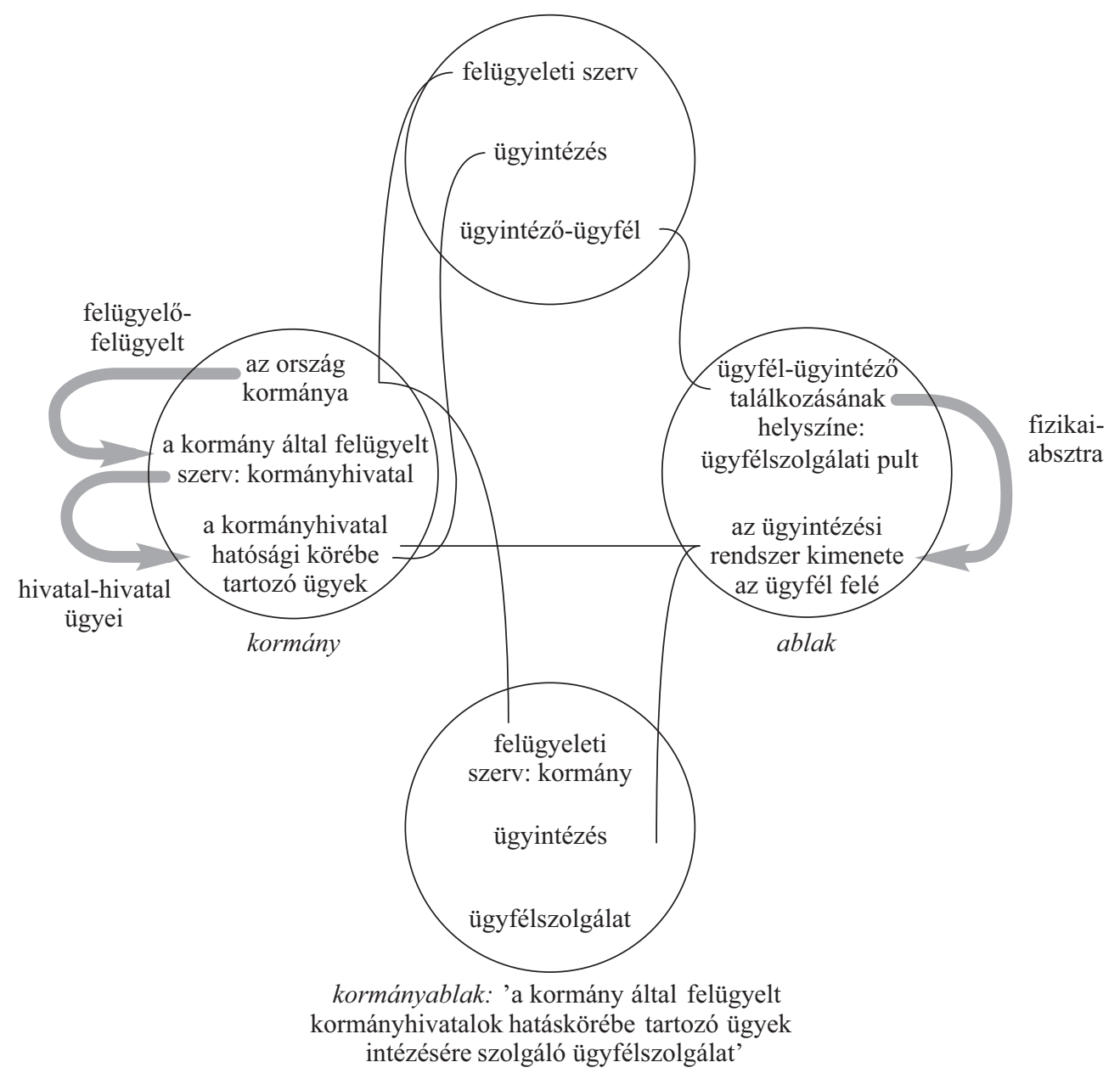

27. ábra: A kormányablak ábrázolása blendként

Összegzésként elmondható a neologizmussal kapcsolatban, hogy a fent vázolt, meglehetösen bonyolult szemantikai szerkezete miatt a jelentésképzés feltételezett folyamata sok esetben akadályokba ütközik. A szemantikai felépítés összetettsége miatt a nyelvhasználóknak feltehetően olyan, speciálisan az ügyintézés és a nemrég megjelent kormányhivatal fogalmához kapcsolódó elözetes ismeretekre van szükségük a szó értelmezésekor, melyek korábbi tapasztalatok nélkül gyaníthatóan nem hívhatók elö. Elözetes ismeretek nélkül, pusztán a szó szemantikai szerkezete alapján nem (vagy igen nehezen) rekonstruálható az összetétel jelentése. 


\subsubsection{1. és 12. esettanulmány: e-könyv, e-könyv olvasó}

A következő elemzendő neologizmus az e-könyv olvasó (másik lehetséges írásmódja: e-könyv-olvasó). Mivel a többszörös összetétel három tagból áll, célszerủ az első két tagja által alkotott alakulatnak, az e-könyvnek a rövid vizsgálatából kiindulni.

Az e-könyv az angol e-book magyar megfelelöje; az interneten a magyar nyelvü szövegekben a mai napig találkozhatunk mindkét elnevezéssel. A szó 'elektronikus formában tárolt és megjelenített, elektronikusan olvasható könyv'-et jelent. Figyelemre méltó az $e$ - rövidítésú, 'elektronikus' jelentésủ előtaggal keletkezett alakulatok nagy száma a magyar nyelvben, például: e-jegyzet, e-cigaretta, e-ellenörzökönyv, e-felvételi, e-képeslap, e-matrica, e-számla stb. Az ISZ-ban megtalálhatók az e-könyv és a most vizsgálandó $e$-könyv olvasó angol megfelelöi e-book és e-book reader alakban (ISZ 2007: 272-273). Az e-könyv olvasó fogalma az e-könyvek olvasásához kapcsolódik, és maga a fogalom két dolgot is jelenthet: vagy 1 . az 'e-könyv olvasására alkalmas hardver'-t, tehát azt a kézzel fogható, térben létező elektronikus eszközt, melyre fel lehet tölteni az elektronikus olvasnivalót, vagy 2 . az 'e-könyv olvasására alkalmas szoftver'-t, melynek segítségével a készüléken az e-könyvet olvasó program müködik. ${ }^{19}$

Az e-könyv olvasó szerepelt a 2011-ben felvett kérdöíves felmérés szavai között is. A 28. ábra diagramján a szóval kapcsolatban írt, a „valódi” jelentéssel egyező magyarázatok, szinonimák számával kapcsolatban kapott eredmények láthatók.

Az e-könyv olvasó felismertsége a kérdőív típusának függvényében (\%) - 2011

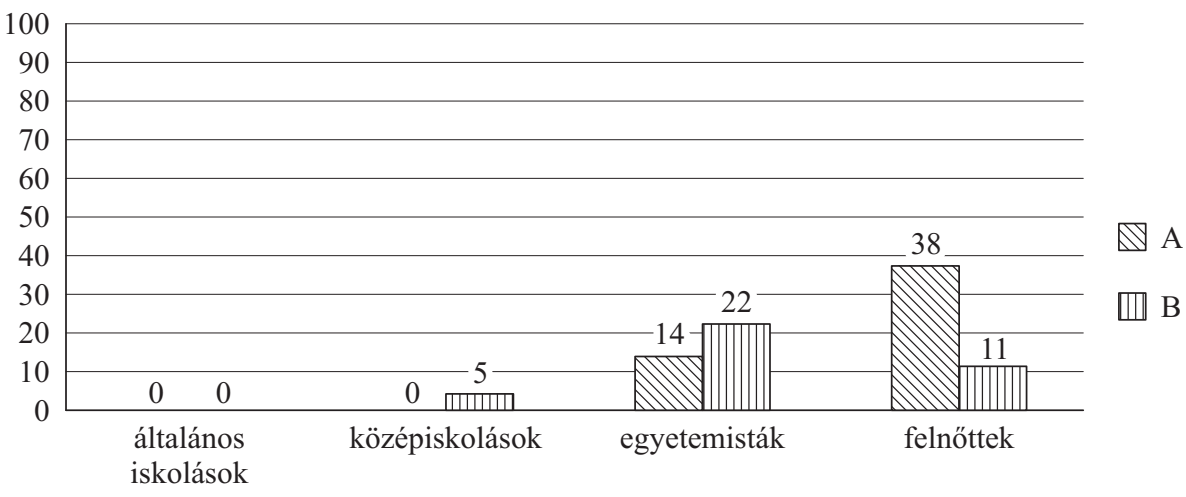

28. ábra: Az e-könyv olvasó felismertsége 2011-ben

Mint a fenti diagram is mutatja, az általános iskolás korosztályban egyetlen olyan válasz sem született, mely a szónak a „valódi” jelentéssel azonos jelentését adta volna meg („,valódi” jelentésben elfogadtam akár a hardverre, akár a szoftverre vonatkozó körülírást, szinonimát). Az egyetemi hallgatók és a felnőttek körében már nőtt a szó felismertsége mindkét típusú kérdőív esetében. A felnőttek körében érdekes eredmény, hogy 
akkor, amikor „B” típusú kérdőívet töltöttek ki, tehát szövegkörnyezetben olvasták a szót, csökkent a felismertség aránya. Ezekben az esetekben a megadott válaszokban sok esetben 'e-könyv'-ként definiálták az adatközlök a vizsgált szót, az olvasó szót (mely szintén kiemelve szerepelt a szövegben) nem értelmezték.

Az adatközlők által megadott magyarázatok, szinonimák közül azokból, amelyek nem egyeztek meg a neologizmus „valódi” jelentésével, többfajta értelmezési stratégia is kirajzolódik. Ezeknek egy része az olvasó szó jelentéséhez kapcsolódik. Jellemző módon az adatközlők egy része ezt a szót nem neológ jelentésében, hanem 'olyan ember, aki olvas' jelentésben értelmezte, és 'e-könyvet olvasó ember' vagy ritkábban 'e-könyvek olvasását lehetővé tevő internetes oldal'-ként magyarázta. Ezek a magyarázatok tehát azért nem azonosak az e-könyv olvasó vizsgált jelentésével, mert az olvasó utótag a kérdéses alakulatban nem az újdonságként megjelent $e$-könyv alakulattal összekapcsolódva 'e-könyv olvasására alkalmas hardver/szoftver' jelentésben jelenik meg. A másik jellemző, a „valódi” jelentéssel nem azonos magyarázat az általános és középiskolás diákok leírásaiban jelent meg (és felhívja a figyelmet az e- előtag félreérthetőségére is a magyar nyelvben): ők sok esetben a mutató névmás rövid alakjaként értelmezték az előtagot, így 'az adott könyvet olvasó', 'ez, aki a könyvet olvassa', 'ezt a könyvet olvasó'-ként értelmezték a neologizmust.

Mint az a fenti körülírásokból is látható, az e-könyv olvasó jelentésének értelmezése során a nyelvhasználók előzetes tapasztalatainak igen nagy jelentősége van, hiszen az alakulat grammatikai-szemantikai felépítése többféle értelmezésre is lehetőséget ad. Mint az adatközlök válaszaiból is kiderült a kérdőíves felmérés során, a nyelvhasználók e-könyv olvasón elsősorban a hardvert értik, tehát 'a számítógép elektronikus, mechanikus stb. (alkat)részeinek összessége' (ÉKsz. ${ }^{2}$ 2003: 493), a 'fizikai valójában megfogható gépezet' jelentésben ismerik a neologizmust. Mint ahogyan az a fórumozó is, aki az alábbi bejegyzést írta (kiemelés tölem $-\mathrm{S}$. R.):

Dávid Csaba 2010. november 25.10:03

Napokban találtam rá az Alcor Poet nevü $\boldsymbol{e}$-könyv olvasóra. A 30ezer forintos árával egész barátságos kis eszköz, viszont azt írják róla több helyen is, hogy az LCD kijelző miatt gyorsabban lemerül, mint e-ink-es társai. (...)

Jó választás lehetne ez az olvasó, vagy inkább egy másik, e-ink-es társa (pl: Koobe) jobb lenne? ${ }^{20}$

A fenti szöveg írója valószínűleg jól ismeri az e-könyv olvasókat, hiszen több típusukat is megnevezi. Feltételezhető, hogy hozzáértőknek ír a témában, hiszen a vásárláshoz kér tölük tanácsot egy számítógépekkel foglalkozó fórumon. Az idézett szövegben megjelennek továbbá olyan terminusok is ( $L C D$ kijelzö, e-ink, márkanevek), melyek szintén a szerző tájékozottságára engednek következtetni. Egyértelmü, hogy a szerző a fenti

20 Forrás: http://www.pcworld.hu/forum/index.php?showtopic=14080 (letöltés ideje: 2011 . november 3.). 
fórumszövegrészletben az e-könyv olvasót a 'hardver, tehát az olvasást lehetővé tevő eszköz' jelentésben használja (erre utal az „egész barátságos kis eszköz” kifejezés és a lemerülésről szóló információ).

A bemutatott kérdőíves felmérés eredményeiből, illetve az idézett fórumszövegrészletből kiindulva úgy gondolom, hogy az e-könyv olvasó megértéséhez feltétlenül szükségesek olyan előzetes tapasztalatok, melyek lehetőséget adnak a befogadónak egyrészt az e-könyv, másrészt az olvasó szavak neológ jelentéseinek azonosítására. A kérdőíves felmérés eredményeiből az is kiderült, hogy ha valakinek vannak is előzetes ismeretei az e-könyvekröl, akkor sem biztos, hogy az e-könyv olvasó jelentését értelmezni tudja, hiszen az olvasó szó is több jelentésben tünhet fel.

Az elmondottak alapján feltételezhető, hogy az e-könyv olvasó szemantikai szerkezetének felépítésében több „neológ” jelentés is szerepet játszik. Úgy gondolom, hogy ezen alakulat szemantikai elemzésénél is eredményesen alkalmazható a fogalmi integrációs elmélet.

Az elemzés során célszerünek tünik a szintén neológ e-könyv szóból kiindulni. Az eelőtag, melynek jelentését az ISZ a következőképpen adja meg: 'valamely nem elektronikus tevékenység vagy dolog elektronikus, számítógépes változata, főképp az interneten megjeleníthető vagy hozzáférhető adatokkal és szolgáltatásokkal kapcsolatban' (ISZ 2007: 272), az elemzendő neologizmusnál 'elektronikus' jelentésben szerepel az egyik bemeneti térben, vele kerül kapcsolatba a könyv utótag. A könyv szónak az ÉKsz. ${ }^{2}$-ben olvasható jelentése tartalmazza a prototipikus könyv jellemzöit: 'egybekötött, lapozható, ívekből álló, rendszerint fedéllel ellátott (nyomtatott) mü' (ÉKsz. ${ }^{2} 2003:$ 748). Ezek a jellemzők jelennek meg a másik bemeneti térben. A két tér kapcsolatából kialakuló generikus térben az ADATOK ÁTVITELE, KÖZVETÍTÉSE fogalmak, az integrált térben pedig az e-könyv legfontosabb, prototipikusnak mondható jellemzői jelennek meg: ez tehát egy elektronikusan lapozható és olvasható mü.

A már meglévő e-könyv és a jellemzöit tartalmazó mentális tér fogja alkotni az e-könyv olvasó alakulat egyik bemeneti terét. A másik bemeneti térben megjelennek az olvasó szónak a korábban már részletezett, újszerú jelentései, tehát az, hogy ez egy informatikai hardver vagy szoftver, amelynek funkciója az, hogy adathordozók tartalmához való hozzáférést tesz lehetővé. Az e-könyv és az olvasó jellemzőit tartalmazó mentális terek mindegyikében közös az olvasás fogalma, így ez a jellemzö a két mentális tér között is kapcsolatot biztosít. Az e-könyv olvasó fogalmát tartalmazó integrált térben végül megjelenik 1. az, hogy ez egy informatikai hardver vagy szoftver, amely 2. elektronikusan lapozható, olvasható művek olvasását teszi lehetővé.

A fent leírtak grafikusan a 29. ábrán látható módon ábrázolhatók (vö. Sólyom 2012b).

Összegzésképpen elmondható, hogy az e-könyv olvasó szemantikai felépítésének a fogalmi integráció keretében történő ábrázolása nemcsak eredményesen bemutatja a neologizmus létrejöttében szerepet játszó folyamatokat, hanem a jelentésképzés modellálásával kapcsolatban arra is rávilágít, a nyelvhasználók milyen előzetes tapasztalatai szükségesek ahhoz, hogy a neologizmust értelmezzék. Ezeknek a tapasztalatoknak a megléte vagy hiánya pedig eredményesen magyarázza a kérdőíves felmérésekben kapott, megértésre vagy félreértésre utaló értelmezési stratégiák eredményeképpen létrejövő jelentésmagyarázatokat. 


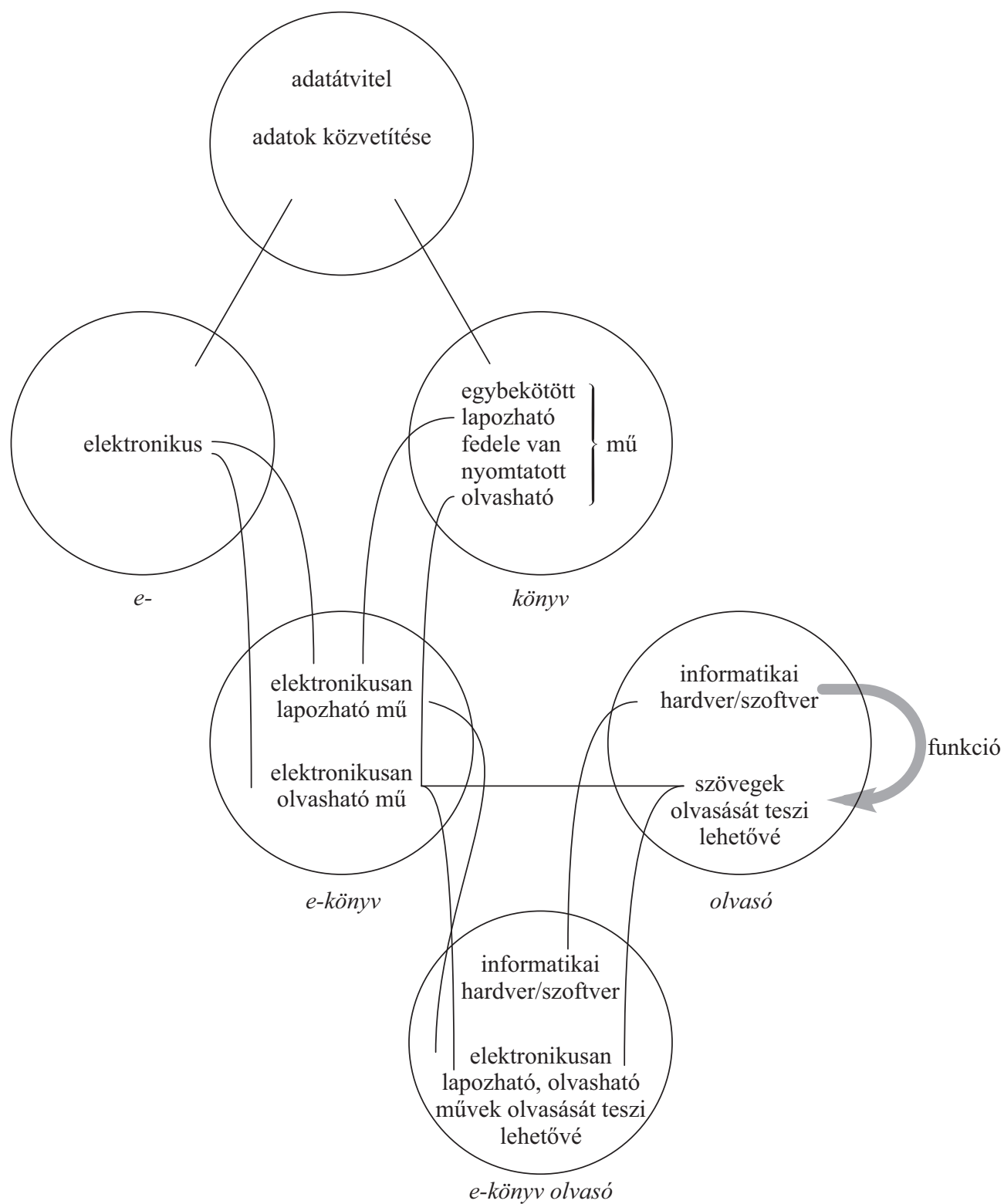

29. ábra: Az e-könyv olvasó ábrázolása blendként 


\subsubsection{3. és 14. esettanulmány: be igekötős igék elemzése}

A következőkben egy napjainkban igen jellemző neologizmustípus, néhány olyan ige elemzése következik, amely be igekötővel jött létre az elmúlt években. Az ilyen típusú neologizmusok vizsgálata szemantikai és kommunikációs szempontból is tanulságos lehet, hiszen bennük az igekötő sok esetben nem elsődleges térbeli jelentésében, két fizikai tárgy térbeli viszonyában (Tolcsvai Nagy 2010: 70) jelenik meg.

A be legrégibb magyar igekötőink közé tartozik: „A be igekötő a $k i$ ellentétes jelentésű párja. A két igekötő funkciói sokszor hasonlóan fejlődtek, egymásnak mintegy tükörképei. A be használata azonban korlátozottabb, előfordulása ritkább, funkciói kisebb számúak, mint az eddig tárgyalt igekötőké. Eredeti jelentésétől kevésbé távolodott el, perfektív szerepe aránylag fiatal" (J. Soltész 1959: 107). A fenti idézet megállapításától némiképp eltérően napjainkban feltünően sok be igekötős neologizmus keletkezik, és az egyes alakulatok gyakran több jelentésben, vonzatszerkezetben is élnek egymás mellett. Az egyik kérdés az, hogy „milyen okokból jönnek létre ezek az alakok: a rendszer szabályainak megfelelő potenciális alakok realizálódásából, puszta szabályszegésből vagy esetleg a rendszer szabályainak átrendeződéséből?”" (Ladányi 2007: 260). A jelen munka az elemzendő be igekötős igék szemantikai szerkezetének részletes bemutatásával kíván hozzájárulni a jelenség keletkezési okainak vizsgálatához.

A szakirodalom a be igekötőnek számos jelentését és funkcióját felsorolja: J. Soltésznál 1. zárt tér belsejébe való irányulás (bemegy), 2. „belsőségbe kerülés” (becsuk), 3. bizonyos térnek vagy felületnek a cselekvéssel, illetve a cselekvés eredményével való megtöltése (bemázol), 4. perfektív funkció (besötétedik, mely eredetileg úgy is értelmezhető: 'sötétséggel megtelik'), 5. az ún. törvénykezési igék (bevádol), 6. evéssel-ivással kapcsolatos igék, ahol az ember „belsejébe” jut valami (bereggelizik), 7. „néhány olyan belső jelentésfejlődés útján létrejött ige, mely a be igekötővel mást jelent, mint igekötő nélkül (beéri vmivel)" (J. Soltész 1959: 116-121). A Strukturális magyar nyelvtan a következő jelentéseket különíti el: 1. irányjelentés, 2. teljesség, totalitás, 3. telítettség, szaturativitás (Kiefer 2000: 484-493). A Magyar grammatika is megemlíti a be igekötőről általánosságban, hogy „elsősorban lexikai-szemantikai szerepű nyelvelem, az igék jelentésének módosítására, megváltoztatására szolgál” (Balogh 2000: 264), hasonlóan az Új magyar nyelvtanhoz (É. Kiss - Kiefer - Siptár 1998: 33-48). A fent említett szakirodalmi áttekintések tehát az igekötőnek a határozószói, jelentésmódosító, befejezett aspektust jelölö és akcióminőség-meghatározó szerepét emelik ki (Tolcsvai Nagy 2005c: 29). Tény azonban, hogy az igekötők esetében a szemantikai átértékelődés folyamata ma sem zárult le teljesen (Pátrovics 2002: 481-482), még az ősi igekötők esetében sem. Az úgynevezett formálódó akcióminőség (Ladányi 2007: 263) ugyanazon neológ szóhasználat esetében is különböző jelentésekhez vezethet.

Ladányi a be igekötőnek a következő új használatait és jelentéseit adja meg: 1. 'valamilyen intenzív/felfokozott lelki vagy tudati állapotba való kerülés és az abban való elmerülés' (szubmerzív akcióminőség), pl. beidegesedik, beszerelmesedik, bekómázik stb., 2. használata más igekötők ,helyett” vagy szokásosan igekötőtlen helyen pl. bedereng, belassul, bedurvul, belazul, betámad, beaggódik stb. (Ladányi 2007: 266-271). 
Megjegyzendő és a későbbi elemzések során fontos szempontként érvényesítendő, hogy az 1. típus esetében végső soron az ÁLLAPOT TARTÁLY fogalmi metafora manifesztálódik (Kövecses-Benczes 2010: 134; Szili 2005: 153).

Az újabban be igekötőt tartalmazó alakulatok egy részében eredetileg más igekötők szerepeltek, azonban az általuk képviselt viszonyok különbsége neutralizálódott, vagy egy általánosabb szemlélet alapján, vagy azért, mert egy másik, a be jelentésében szerepet játszó mozzanat emelődött ki az alakulatban (Ladányi 207: 272). Utóbbinak oka lehet a már említett ÁLLAPOT TARTÁLY fogalmi metafora (erre látunk majd példát az alábbiakban elemzendő betámad és becéloz igék esetében). Ami tehát a (meg)támad-betámad, (meg)céloz-becéloz igék különbségét illeti, a be igekötős alakokban jelentéstöbblet figyelhető meg. Az 'eredményesség/befejezettség' jelentésmozzanathoz hozzájárul még az 'eltúlzottság', 'teljesség' mozzanata is, hasonlóan a Ladányi által említett további példákhoz (befertöz, bealáz, befenyit, betámad, bevéd, behirdet, berémül, befeszit, bekövesedik, bekeményedik, bedermed, berothad, Ladányi 2007: 275).

Az igekötős ige jelentésszerkezete a kognitív nyelvészet módszereinek segítségével úgynevezett kompozitumszerkezetként írható le, melyben a komponensszerkezetek „külön-külön is érthető jelentésszerkezete kölcsönös kidolgozásban kerül viszonyba egymással" (Tolcsvai Nagy 2001b: 93-98; 2005c: 28; 2010: 101-103). Az ilyen típusú öszszetett jelentésszerkezetekben emergencia érvényesül, vagyis „az egyes jelentéses nyelvi elemek együttese más szemantikai minőséget hoz létre” (Tolcsvai Nagy 2010: 73).

Az olyan neologizmusok esetében, amelyeknek több jelentésük is van, és a térbeliségre utaló jelentésükön túl a diskurzusban megjelenik más (például metaforikus vagy aspektuális) jelentésük is, mindegyik jelentés vizsgálható, vizsgálandó. A magyar nyelvben az igekötős ige is értelmezhető a Fauconnier-Turner-féle fogalmi integrációs modell műveleteinek segítségével (Tolcsvai Nagy 2005c: 34; Kövecses-Benczes 2010: 202).

\subsubsection{13. esettanulmány: betámad}

Az első elemzendő példa a betámad. Az igének három különböző jelentését mutatom be három kiválasztott fórumszövegrészletben, majd a fogalmi integrációs elméletet alapul véve mindhárom esetben bemutatom az ige szemantikai szerkezetének felépítését.

A vizsgálandó szövegrészletekben az egyébként is poliszém támad ige több jelentése jelenik meg. Ezek közül három az elemzendő példák jelentésére is hatással van. E jelentések az ÉKsz. ${ }^{2}$ szerint 1. 'váratlanul keletkezik, illetve hirtelen kialakulva feltünik', 2. 'fegyveres összecsapást kezdeményez', illetve 3. 'erősen (és indulatosan v. vádaskodva) kifogásol, hevesen bírál' (ÉKsz. ${ }^{2} 2003: 1301$ ). Hasonló poliszémia jellemző a megtámad igére is, ennek három olyan jelentését közli az ÉKsz. ${ }^{2}$, amely a lenti példákkal kapcsolatba hozható: 1. 'támadást intéz, indít vki, vmi ellen', 2. 'káros, romboló hatást kezd kifejteni vmi(be)n', 3. 'vádoló, sértő v. számon kérő hangon nekitámad vkinek, vminek' (ÉKsz. ${ }^{2}$ 2003: 904). Mint azt a lenti szemantikai elemzések is be fogják mutatni, a betámad esetében a $b e$ igekötővel létrejövő alakulat feltehetően analógiás módon funkcionál ezekben a szerkezetekben, vagyis a be igekötö a megtámadban szereplö meghez hasonlóan perfektiváló szerepben tünik fel, így ezekben az esetekben a be igekötő napjainkban 
zajló szemantikai „kifehéredési” (Sweetser 1988: 390, idézi Szili 2005: 151; Haiman 1991: 154) folyamatának, grammatikalizációjának is tanúi lehetünk. A be igekötő ráadásul több esetben igen összetetté teszi az igekötős ige jelentését, hiszen nem (pusztán) térbeli irányultság, hanem a perfektivitás (Szili 2005: 153), illetve esetenként e két aspektus együttes jelenléte befolyásolja a kialakuló igekötős igék jelentését.

A betámad szerepelt abban a kérdőíves vizsgálódásban, amelyet 2010 májusában és júniusában végeztem (vö. Sólyom 2012a). A betámad esetében az adatközlők által szinonimaként megadott javaslatokból kiderült, hogy minden korosztály válaszaiban megjelentek olyan szinonimák, amelyek a szó metaforikus vagy metonimikus jelentésátvitellel értelmezett jelentéseit adták meg (pl. aláás, bánt, bekóstol (sic!), felelösségre von, kötekedik, lehurrog, leszól, megdönget (sic!), megsért, nekimegy, rágalmaz, rányomul).

Megjegyzendő, mert a be igekötő funkcióváltozásának folyamatában releváns információ lehet, hogy az adatközlők a véleményüket kérdező pontban egyébként meglehetősen negatívan vélekedtek a betámadról (az adatközlőknek mindössze 2 százaléka vélte úgy, hogy „kifejezetten tetszik” neki a szó): volt, aki az igekötő megjelenését kifogásolta, funkciótlannak érezte, mások pedig kimondottan durvának, agresszívnek vélték az alakulat jelentését, akár fizikai, akár lelki támadásként értelmezték a szót.

A betámad felismertségével kapcsolatban - a fejezetben elemzett elöző példákkal ellentétben - nem mutatok be eredményeket; ezek számszerüsítése ugyanis éppen az ige poliszém jelentései miatt nem lenne releváns. Az adatközlők az idézett kérdőíves felmérésben ugyanis gyakran több jelentését is megadták a vizsgált igéknek, valamint sok esetben olyan árnyalt körülírásokat is megadtak, amelyeket nem lenne célszerü igen-nem alapon csoportosítani aszerint, hogy teljes mértékben megegyeznek-e a neologizmus „valódi” jelentésével, vagy sem. Célravezetőbbnek tartom (és a másodikként elemzendő becéloz ige esetében is így járok el), hogy az ige új keletkezésü, neológ jelentéseinek szemantikáját különbözö szövegkörnyezetben bemutatva elemezzem.

A következőkben a betámad három különbözö jelentésére mutatok be esettanulmányokat; a korpuszt ez esetben is fórumszövegek részletei szolgáltatják.

A (33)-as számú szövegrészlet egy macskatartással foglalkozó fórumról származik (a macskatartók az elözményekben arról beszélgetnek, hogy mit lehet tenni akkor, ha a macska játék közben fájdalmat okoz a gazdájának, kiemelések tőlem - S. R.):

Mawyx 2010. 02. 18. 06:48:07

Enyém is így játszik, de ha kiabálok azt nem szereti. Bár általában úgy belelendül hogy ugye alapból a kezem marcangolja, rácsapok kicsit, hogy elég volt, de ez nem elég hatásos, elfordulok és felállok, akkor meg totál betámad. Nem a kezem akkor már, hanem rám ugrik, a testemre vagy fel a combomra, átkarolja és ott csüng belém akasztott körmökkel Önbizalom az van, hogy így simán betámad, pedig az ő nagyságának sokszorosa vagyok, de úgy véli, le tud teríteni ${ }^{21}$

21 Forrás: http://itcafe.hu/tema/nagy_macskatopic/hsz_6301-6350.html\#msg6302 (letöltés ideje: 2011. március 18.). 


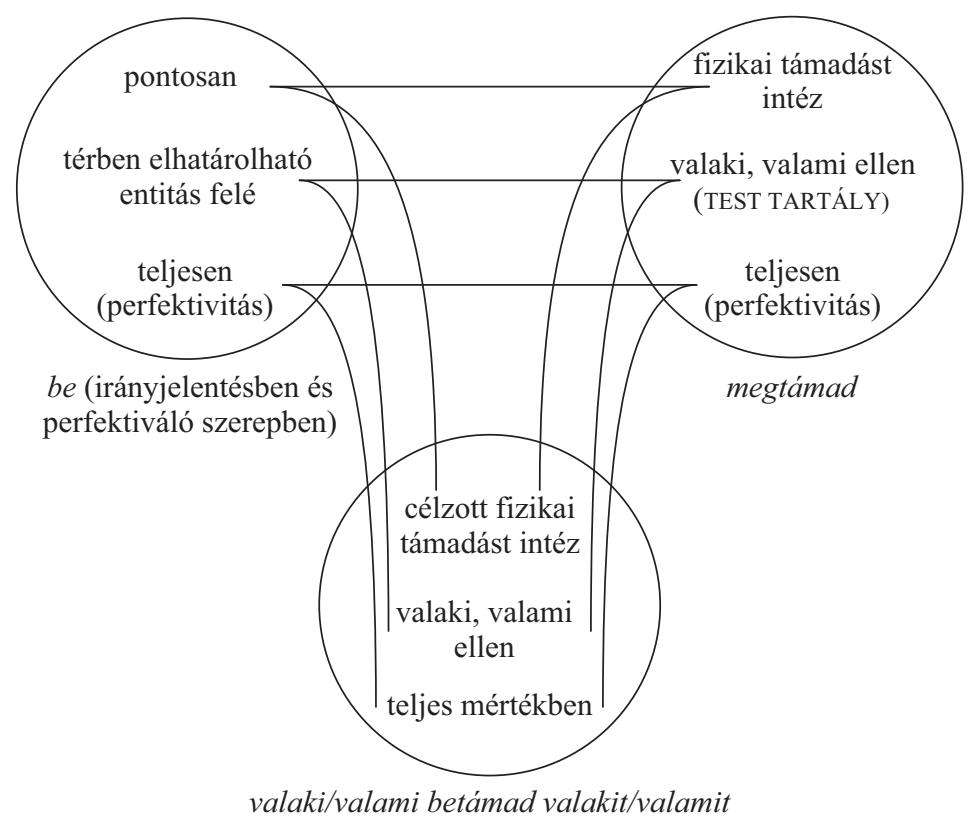

30. ábra: A valaki/valami betámad valakit/valamit ábrázolása blendként

A valaki/valami betámad valakit/valamit a fenti fórumszövegrészletben 'fizikailag (meg)támad valakit' jelentésben szerepel. Az igekötő megjelenése az EMBERI TEST TARTÁLY fogalmi metaforát hívja elö, melyet egy külső erő veszélyeztet. A betámad e neológ jelentésének a fogalmi integrációs elmélet keretében történő ábrázolásakor - az adatközlők által is megadott szinonimák alapján - célszerủnek tủnik a be igekötő jelentéseiből és a megtámad ige jelentéséből kiindulni. Ezek a jelentések fogják a blend két bemeneti terét szervezni. A betámad fenti jelentésének kialakításában részt vevő be igekötő irányjelentésében kifejti a támadásnak az alanyra irányulását, megjelenik továbbá az igekötő perfektiváló funkciója is, mely a folyamat teljességét, totalitását adja. Mivel az igekötőt, illetve a megtámad igét tartalmazó két bemeneti tér jelentésében, illetve funkciójában igen különböző, viszont a neologizmus jelentésének kialakításában mindkettő aktívan részt vesz, generikus tér nem jelenik meg a betámad neológ jelentésének kialakulása során. A fentiek alapján a betámad e jelentése a 30. ábrán látható módon ábrázolható a fogalmi integrációs modellben (vö. Sólyom 2012c: 277).

A második példában a betámad más jelentésben jelenik meg. A (34)-es számú szövegrészletben egy lótartással kapcsolatos kérdésre válaszol egy fórumozó:

realcowboy 2003. 06. 19, 23:06

Nálunk (PKN. ranch) Parelli módszerét használjuk a lónevelésben. A létezéséről sokan tudunk akit érdekelt a dolog Szentestöl az Alföldön át az Örségig. Sajnos ez olyan dolog ami- 
ről írogatni nem nagyon lehet, mert vagy kiröhögnek és legyintenek rá, vagy csak betámad érte valaki aki el sem tudja képzelni miről lehet szó! ${ }^{22}$

A valaki betámad valakit valamiért esetében ismét megjelenik a TARTÁLY metafora, ám ebben az esetben az emberi lélek (és a mögöttes elme) metaforizálódik, és a (verbális) támadás is ez ellen irányul. A betámad szemantikai szerkezetének ebben a jelentésben történő ábrázolásakor a fogalmi integrációs modellben az előző esethez (30. ábra) hasonlóan generikus tér nem jelenik meg: az igekötő és a megszokottabbnak számító megtámad ige szolgálnak bemeneti térként, utóbbi azonban 'hevesen bírál, vádol' jelentésben. A be igekötő megjelenése a neológ alakulatban véleményem és a kapott adatközlői szinonimajavaslatok szerint a bírálat célzottságát, pontosságát és totalitását erősíti fel. Mindezek alapján a szó blendként ebben az esetben a 31. ábrán látható módon ábrázolható (vö. Sólyom 2012c: 279).

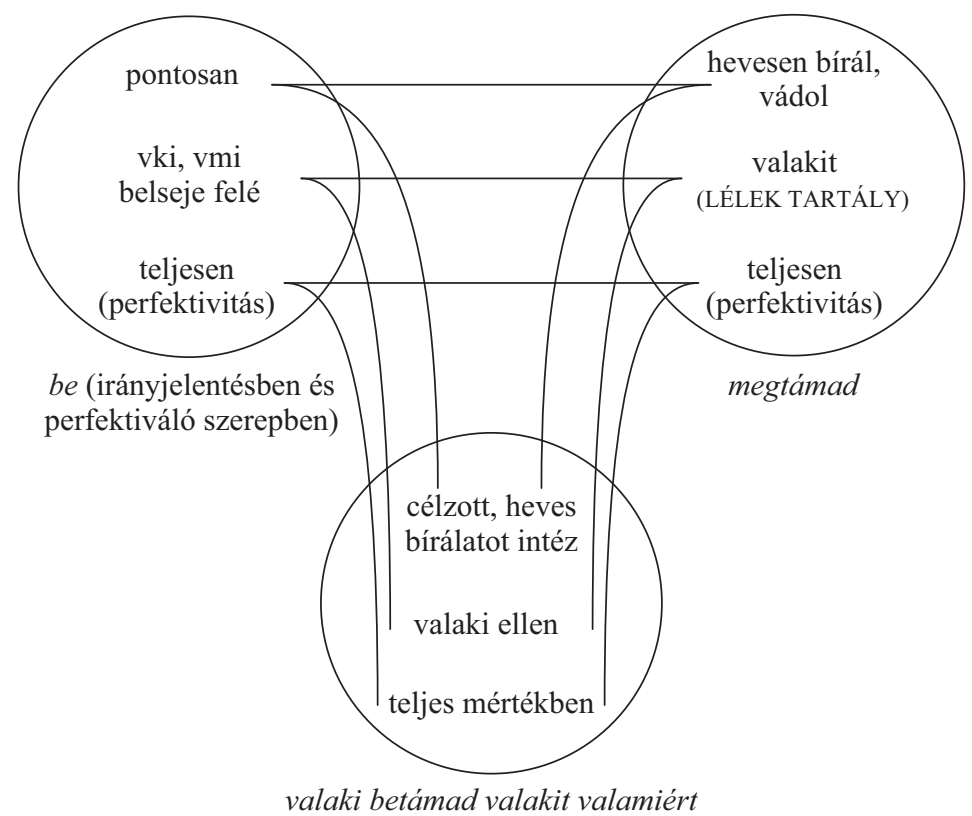

31. ábra: A valaki betámad valakit valamiért ábrázolása blendként

A betámad harmadik jelentésében a (35)-ös számú szövegrészletben jelenik meg (az előzményekben a fórumozók egy közelgő szabadtéri rendezvény napján várható időjárást latolgatják, kiemelések tőlem - S. R.): 
Only1 2010. 08. 10 18:36:32

Tőlem szakadhat is már megszoktuk hogy ha van valami banzáj betámad a ,jó idő” minket amitől már nem nagyon ijedünk meg, úgyhogy ha piros hó esik is meg lesz tartva a találkozó $\odot-()+23$

A betámad ebben a kontextusban ismét más jelentésben jelenik meg, mint az előző két szövegrészletben. A fórumozó 'váratlanul keletkezik, és negatív következményekkel fenyeget' jelentésben használja, az időjárásra vonatkoztatva, hasonlóan a kedve támad, feltámad a szél, támad a fagy stb. kifejezésekhez. Az idézett szövegrészletben igekötövel és tárgyi vonzattal jelenik meg a támad. Használata felerősíti azt a fenyegetettséget, melyet a tervezett program rossz idő esetén történő esetleges elmaradása miatt érezhetnek a fórumozók. Az idézőjelbe tett ,jó idő” iróniája igyekszik oldani ezt a feszültséget, csakúgy, mint az utolsó hozzászólás humora, bátorítása (nem nagyon ijedünk meg, ha piros hó esik is, emotikonok). A be igekötő jelenléte ebben az esetben is utalhat az egyén fizikai terére (a TEST TARTÁLY fogalmi metafora alapján), melyet például egy zápor veszélyeztethet, és/vagy utalhat magára a szabadtéri rendezvényre is, amelyen (amelyben?) metaforikusan részt vesznek a fórumozók, és amelyet a rossz idő fenyeget.

A valami betámad valakit/valamit ('váratlanul keletkezve utolér') szemantikai szerkezete szintén ábrázolható a fogalmi integrációs modell keretében. A bemeneti terek egyikében, a be igekötő oldaláról ismét megjelenik a pontosság, a befelé irányulás és a perfektivitás. A megtámad vagy feltámad igék jelentése által kidolgozott területek pedig a váratlanságot, valakinek vagy valaminek a támadását és a $m e g / f e l$ igekötők által kifejezett perfektivitást jelenítik meg. A támadás elszenvedője, az egyén vagy maga a helyszín mint fizikai létező ismét a TARTÁLY metaforában manifesztálódik. A generikus tér a fentiek értelmében ebben az esetben sem jelenik meg. Az elmondottak grafikusan a 32. ábrán látható módon ábrázolhatók (vö. Sólyom 2012c: 281).

A betámad igének az előzőekben bemutatott elemzései során a fogalmi integrációs modell segítségével sikerült rámutatni arra, hogy egy-egy neologizmus poliszém jelentéseinek kialakulásában milyen mentális és szemantikai folyamatok játszanak szerepet. A modell lehetőséget biztosíthat arra is, hogy segítségével a jövőben bekövetkező esetleges jelentésváltozásokat tanulmányozzuk.

\subsubsection{14. esettanulmány: becéloz}

A második elemzendő példa a becéloz, mely szintén változatos jelentésekben tünt fel az elmúlt évek magyarnyelv-használatában. Ez az ige is szerepelt a 2010 nyarán felvett kérdőíves vizsgálódásban; a jelen elemzésben az adatközlőknek a szóval kapcsolatban megfogalmazott véleményét, attitüdjét ábrázoló diagramot közlöm, mivel a 2010-es kérdőíves felmérésben az adatközlőknek ennek a szónak az esetében is lehetőségük volt arra, hogy leírják a véleményüket vele kapcsolatban. A 33. ábra diagramján, amely a be- 


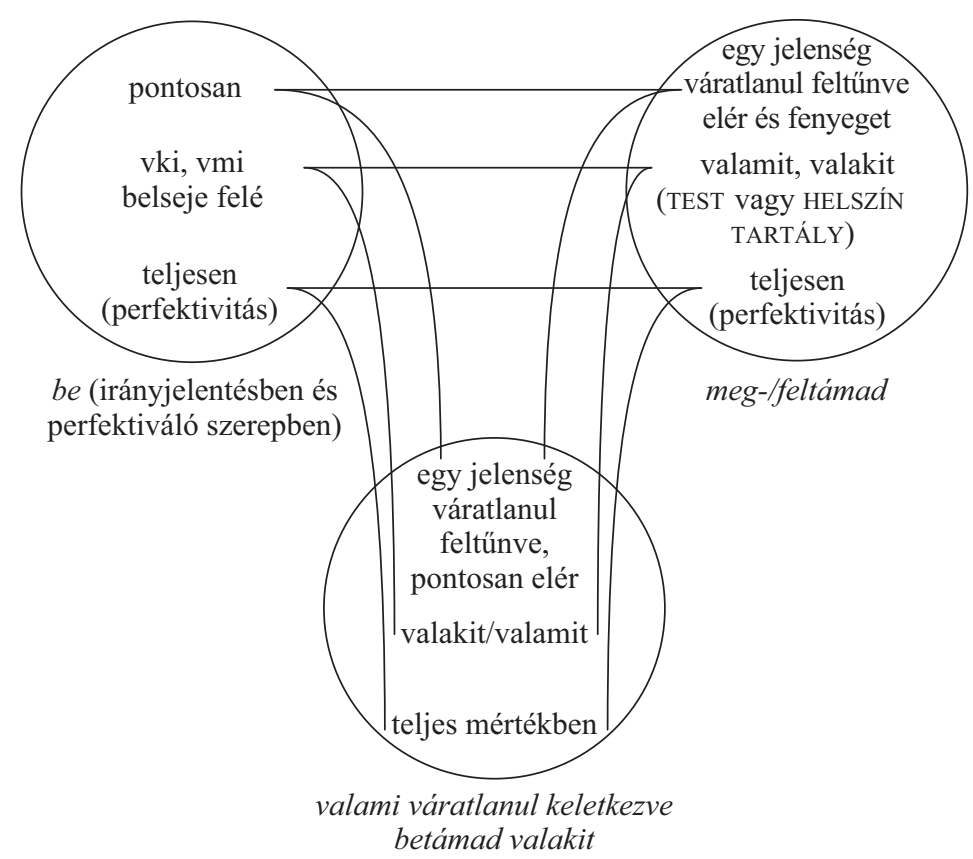

32. ábra: A valami váratlanul keletkezve betámad valakit ábrázolása blendként

célozra vonatkozó eredményeket ábrázolja, látható, hogy azok között az adatközlők között, akik leírták véleményüket ezzel a neologizmussal kapcsolatban, három korcsoport esetében többen voltak, akiknek „kifejezetten nem tetszett” a szó, mint azok, akiknek „kifejezetten tetszett”. Azok, akiknek nem tetszett a szó, a betámadhoz hasonlóan itt is az igekötő megjelenését kifogásolták, jelezve, hogy inkább más igekötôt használnának helyette. ${ }^{24}$ Azok közül az adatközlök közül, akiknek tetszett a szó, néhányan megjegyezték, hogy igen szemléletesnek tartják a be igekötő megjelenését a céloz ige elött, és úgy érzik, hogy a fiatalos, kissé szlenges nyelvhasználatban adekvát a becéloz használata, tehát a be efféle funkcióváltozását kifejezetten pozitívnak tartják.

A szó szemantikai felépítéséhez a fentiek annyiban kapcsolódnak, hogy azokban az esetekben, amikor az adatközlők szinonimajavaslatokat adhattak meg a becélozra, sok esetben helyettesítették a be igekötőt más igekötővel (megcéloz), vagy a cél szót tartalmazó más kifejezést adtak meg a neologizmus helyett (célba vesz). Megfigyelhetö

24 E helyütt meg kell jegyezni, hogy a 2010-ben felvett kérdőíves felmérésben nagyobb számban egy másik be igekötős igével, a bevállallal kapcsolatban vélekedtek pozitívan az adatközlők, közülük is elsősorban az egyetemi hallgatók és a felnőttek. Leírásuk szerint a be igekötő ennek az igének az esetében sokkal jobban érzékelteti a vállalás merész, gyakran kockázatos voltát. Másrészt szerintük a be igekötő „szlengessége” miatt lazábbá, felhőtlenebbé teszi a társalgást; több adatközlő pedig külön kiemelte, hogy a neologizmusból képzett bevállalós melléknév használatát informális szituációkban kifejezetten jónak tartja, és maga is gyakran használja (vö. Sólyom 2012a). 
Az adatközlők véleménye a becélozról (\%) - 2010

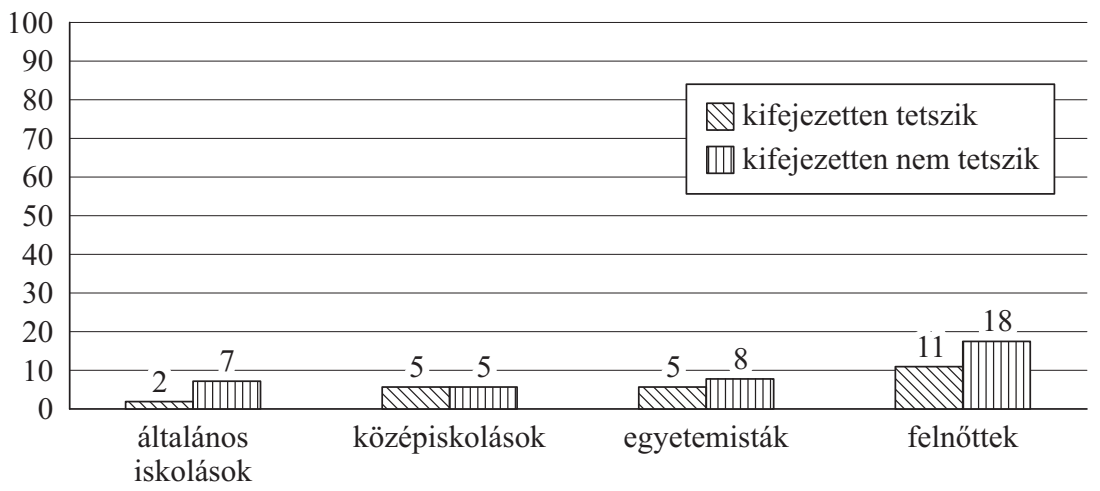

33. ábra: Az adatközlök véleménye a becélozról 2010-ben

volt továbbá az életkor növekedésével a szinonimajavaslatok, körülírások fokozatos árnyaltabbá válása: míg az általános iskolás korosztály esetében a szónak főként a konkrét, térbeli irányt kifejező jelentése jelent meg a szinonimákban, addig a másik három korosztályban olyan metaforikus jelentésszerkezetet mutató szinonimák is, mint például 'elhatároz', 'eltervez', 'kiszemel', 'összpontosít', 'szükít egy témát' stb.

A kapott eredményeket magyarázza a céloz ige szemantikája: ez az ige is több jelentésben, szó szerinti és metaforikus használatban él: 1. 'célpontra irányít', 2. 'burkolt megjegyzést tesz', 3. 'az a célja, hogy...' (ÉKsz. ${ }^{2}$ 2003: 166). Ezeknek a jelentéseknek fontos szerepük van a neológ alakulat jelentésének szervezésében is. A következőkben egy blogbejegyzés és egy fórumszövegrészlet felhasználásával fogom bemutatni a becéloz kétféle jelentésének szemantikáját; a vizsgált neologizmus más-más jelentésben szerepel a két szövegrészletben.

Az (36)-os számú szövegrészlet írója olyan esetről számol be, amelyben feltételezése szerint a testi épsége forgott veszélyben (kiemelés tölem - S. R.):

2009. 04. 02 17:05

Egyik este a Zách Hős sarok előtt egy csoportosulás volt az utcán, a társaságtól ellépve egy kisgyerek kődobást (utólag szerencsére csak) imitált felém. Akkor ezt még nem tudva, abban bízva, hogy nem talál el erősen ráfogtam a kormányra és vártam a becsapódást (...) de mint fentebb említettem csak kamuzott. Hát volt adrenalin rendesen... Gondoljatok bele, tekersz ezerrel és látod egy gyerekforma kijön az út szélére és bal kézzel becéloz és a jobb keze hátul... 25

25 Forrás: http://criticalmass.hu/blogbejegyzes/20090402/hos-utca-lerobbant-resze-keruld-el-ha-nemvagy-bevallalos (letöltés ideje: 2010. július 5.). 
A szövegkörnyezetböl kiderül, hogy a célzó becélozta a kerékpárost. A szöveg fenti jellemzői utalhatnak 1. a célzás előre eltervezettségére, 2. várható pontosságára is (ezt a szerző is érezte: „Hát volt adrenalin rendesen...”).

Ami a be igekötő megjelenését illeti, érdemes röviden összevetni az alakulatot a megszokottabb megcéloz ige használatával, és csakúgy, mint a betámad esetében, ennek az összehasonlításnak az alapján vizsgálni meg a neologizmus szemantikai szerkezetét. A be igekötő perfektiváló szerepe ugyanúgy megjelenik, mintha a meg igekötőt használta volna a szöveg írója; az aspektus tekintetében a becéloz tehát megegyezik az elterjedtebb megcé$l o z$ jelentésével. Különbség és újdonság feltehetően két másik szerepben jelenik meg: a be igekötő ugyanis egyrészt lehetőséget ad a nyelvhasználónak, hogy a célzás térbeli pontosságát, tökéletességét kifejezze; ez pedig abból adódik, hogy - eredeti jelentésénél fogva az igekötő utal arra, hogy egy térben elhatárolható entitás (belseje) felé irányul a célzás. Ez a jelentés pedig már implikálja a TARTÁLY fogalmi metafora megjelenését: a megcélzott entitás mint tartály határolódik el a környezetétől. A fenti szövegrészlet esetében ez a tartály egyértelmủen a megcélzott egyén testi valósága (a feltételezett kődobás a testi épségét veszélyezteti), így a fogalmi metafora a TEST TARTÁLY formában artikulálódik.

A fogalmi integráció elméletének alkalmazása a becéloz szemantikai szerkezetének feltárásában is gyümölcsözö lehet. A fent leírtaknak megfelelően a neologizmus jelentését a becéloz esetében is a be igekötö és az elterjedtebb, korábbi keletkezésủ meg igekötővel álló megcéloz ige szervezi, így célszerü ezek jelentéseinek összetevőiből kiindulni az integráció bemeneti tereiben. Ebben az esetben a két bemeneti tér tartalmának szemantikai különbsége miatt nem jelenik meg generikus tér az alakulat jelentésének szervezésekor: a bemeneti terek tartamának összetevői az integráció eredményeképpen az integrált térben jelennek meg. A be pontossága a megcéloz 'célba vesz' jelentésével, a térben elhatárolható entitás belseje felé irányulás a TEST TARTÁLY fogalmi metaforával kerül a leképezés során kapcsolatba. A már említett perfektiválás pedig mind a be igekötő, mind a megcéloz ige esetében jelen van, így ezek a neologizmus jelentésében a célzás, célzottság, és a fenyegetettség teljességét dolgozzák ki.

A fent bemutatott jellemzők grafikusan a 34. ábrán látható módon ábrázolhatók a fogalmi integrációs modellben.

A második esettanulmány a becéloz szemantikai vizsgálatában a neologizmusnak egy másik jelentését mutatja be. Ebben az esetben a céloz igetőnek a fentebb már ismertetett 'burkolt megjegyzést tesz' jelentése profilálódik, így a becéloz ebben az esetben nem a fizikai térben, hanem metaforikusan, az ember lelki vagy szellemi tevékenységére utaló célzásként, kritikaként jelenik meg.

A (37)-es példa szövegrészletének előzményeként a fórumon egy kérdés jelent meg, amelyben a fórumozó aziránt érdeklődik, hogy vajon célzásképpen adott-e neki az anyósa páros számú virágot a születésnapjára, vagy pusztán tudatlanságból fakadó félreértésről van-e szó. A szöveg írója úgy érzi, anyósa ezzel a tettével provokálja, mert tudomása szerint a temetőbe szokás páros számú virágot vinni. A becéloz az egyik válaszoló által írt szövegben jelenik meg, ahol a fórumozó arra biztatja a kérdezőt, hogy ha legközelebb ilyen eset történik (vagyis ha az anyós újra becéloz), akkor vágjon vissza (kiemelés tölem - S. R.): 


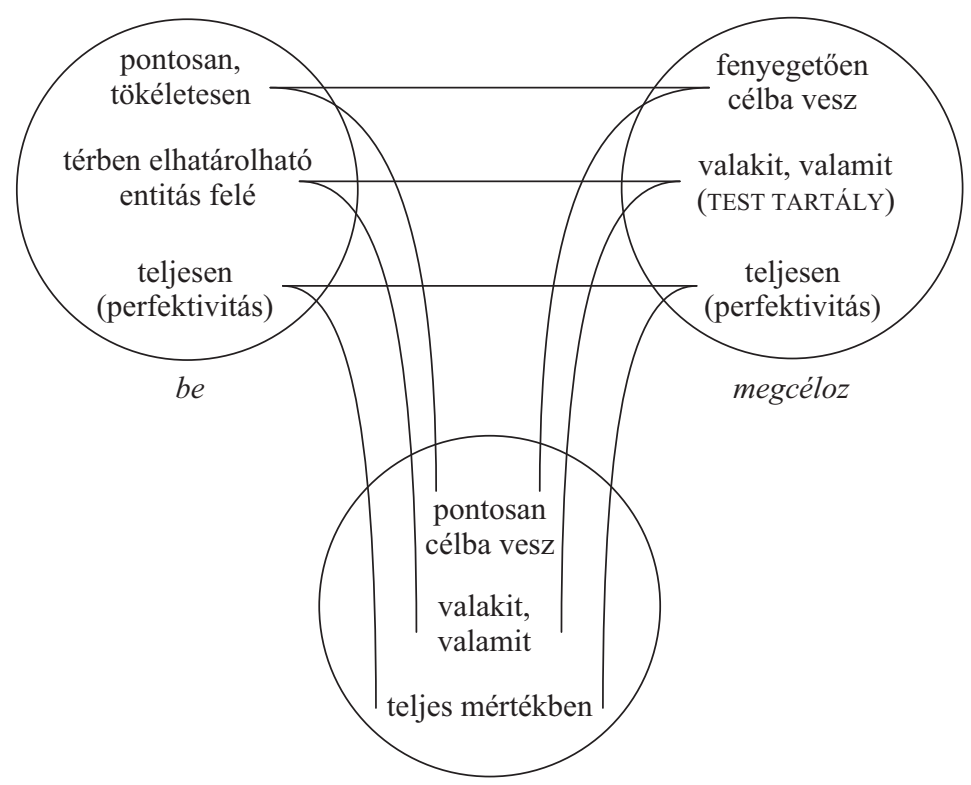

valaki/valami becéloz valakit/valamit

34. ábra: A valaki/valami becéloz valakit/valamit ábrázolása blendként

A válasz

Bizony úgy van a páros számú virágot a halottaknak szokták vinni. (...) Szerintem enyhe célzás akart lenni hova kíván vagy ennyire tudatlan és tényleg jót akart ezért szerintem most hagyd a francba, de ha legközelebb becéloz vágj vissza. ${ }^{26}$

A becéloz neológ jelentésének szemantikai elemzéséhez, célszerü a céloz ige már említett jelentéséből kiindulni, illetve a be igekötő jelentésszervező funkcióiból. Ezeket a jellemzőket feltárva és felhasználva a szemantikai elemzésben, a fogalmi integrációs elmélet keretében a vizsgált igének ez a jelentése is sikeresen vázolható.

Ebben az esetben a be igekötő olyan helyen jelenik meg, ahol korábban nem feltétlenül szerepelt igekötő. A becéloz másik, az előzőekben tárgyalt jelentésével ellentétben így itt nem használható a megcéloz alakulat a neológ jelentés feltárásában. Magának a céloz igének él a 'burkolt megjegyzést tesz' jelentése, mely sok esetben negatív megjegyzések, célzások esetében használatos. A becéloz a fenti kontextusban egyértelmüen negatív konnotációjú: olyan célzást jelent, mely bántó, sértő vagy provokáló lehet a célszemély számára. Mindezek alapján a fogalmi integráció elméletének alkalmazásakor a

26 Forrás: http://www.gyakorikerdesek.hu/csaladi-kapcsolatok egyeb-kerdesek 60533-szuletesnapomra-tiz-szal-rozsat-kaptam-ajandekba-anyosomtol-en-ugy-tanultam-ann (letöltés ideje: 2010. 07. 13.). 
jelen esetben egyrészt a be igekötő jellemzői, másrészt pedig a céloz ige jelentése jelenik meg a két bemeneti térben. A céloz ige szemantikája esetében a burkolt utalás valakinek a mentális vagy lelki stb. állásfoglalása, véleménye ellen szól. Mivel azonban a kritika sokszor nem jogos, az utalás rosszindulatú, célja a legtöbb esetben a sértés, felháborítás, provokálás. Ezek alapján a céloz ilyen jelentésében a LÉLEK TARTÁLY metafora manifesztálódik, ez ellen irányul a burkolt célzás. Úgy gondolom, hogy jelentésénél és perfektiváló aspektusánál fogva a be igekötő a fenti kontextusban képes arra, hogy a rosszindulatú utalás lényegre törő voltát hangsúlyozza. Másrészt az igekötő azt is tartalmazza, hogy az utalás, bár implicit, pontos, lényegre törő, vagyis olyan jellemzőt tartalmaz, mely a befogadó számára egyértelmúen érthető és negatív konnotációjú. Ennek az alakulatnak az esetében sem hanyagolható el továbbá az igekötő perfektiváló funkciója, mely a folyamat sikerességét, totalitását fejezi ki.

Az elmondottak grafikusan a 35. ábrán látható módon ábrázolhatók.

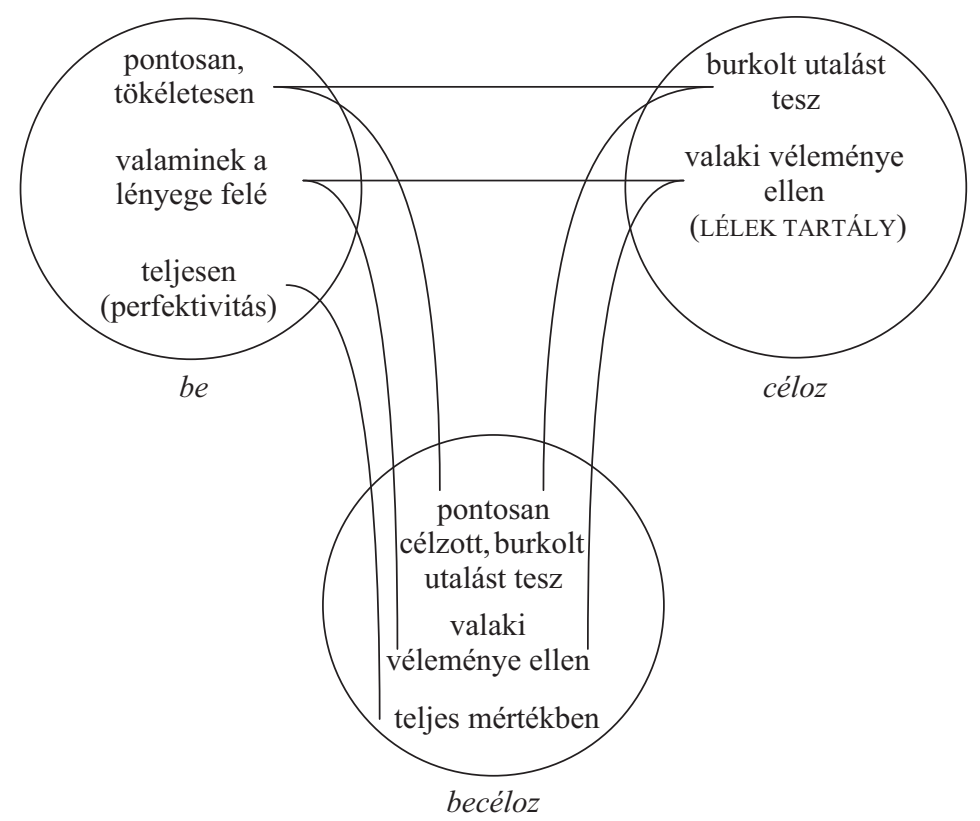

35. ábra: A becéloz ábrázolása blendként

A fentiek alapján megállapítható, hogy a $b e$ igekötő megjelenése a részletezett jellemzöknek köszönhetően jelentős mértékben árnyalhatja a céloz ige jelentését, adott szövegkörnyezetben a rossz szándékot és a kritika célzottságának tökéletességét fejezve ki. 


\section{6. Összegzés}

A jelen fejezet célja az volt, hogy a fejezet bevezetésében közölt, meghatározott szempontok alapján kiválasztott neologizmusok szemantikai szerkezetének elemzési lehetöségét bemutassa. Az elemzett neologizmusokat minden esetben szövegkörnyezetben, internetről származó szövegrészletekben közöltem..

Az elemzések a korábbi fejezetekben tárgyalt szemantikai jellemzőket vizsgálták: a neologizmusok szemantikai szerkezetének feltárásában, valamint a jelentéskonstruálás feltételezett folyamataiban mutatták be, hogy milyen szerepe van bennük a metaforikus és metonimikus jelentésviszonyoknak, illetve a lehetséges asszociációknak, melyeket a hangzásbeli és/vagy jelentésbeli megfelelések hívnak elő. A feltételezett folyamatok modellálásában az elmúlt években felvett kérdőíves felmérések eredményei nyújtottak segítséget.

Az elemzett szemantikai jellemzők feltárásában igen gyümölcsözőnek bizonyult a fogalmi integrációs elmélet: a bemutatott neologizmusok szemantikai szerkezetében megjelenő, gyakran bonyolult összefüggések bemutatásában, a leképezések plauzibilissá tételében nagy segítséget jelentett az elmélet tereinek müködése, illetve a grafikus ábrázolási lehetőség. 


\section{5. ÖSSZEGZÉS, KITEKINTÉS}

A jelen müben bemutatott vizsgálódás fó célja a mai magyar nyelvben megjelenő neologizmusok szemantikájának tanulmányozása volt. Az első három fejezet a kiválasztott neologizmusok szemantikai szerkezetének elemzését kívánta megalapozni. Az első fejezet az elméleti keretet mutatta be röviden, a második és a harmadik fejezet magyar és nemzetközi szakirodalmon alapuló áttekintése pedig a negyedik fejezet részletes elemzéseit készítette elő.

A második fejezet célja többrétü volt: egyrészt igyekezett időrendben bemutatni a neologizmusok jelenségének megközelítési lehetőségeit, módjait. Ennek során elsősorban azokra a jellemzőkre fókuszált, amelyek segítségével érzékeltetni lehet, hogy a neológ jelenségek megjelenése, elterjedése vagy eltünése a nyelv életének természetes velejárója, illetve a nyelvi változás összetett, több szempontból megközelítendő folyamatának része. Érzékeltette továbbá, hogy a funkcionális-kognitív nyelvészeti megközelítés milyen lehetőségeket nyújt a neologizmusok problémájának tanulmányozásához; ennek érdekében került sor néhány terminus technicus tisztázására.

A második fejezet rámutatott arra is, miért szükséges olyan neologizmusdefiníció megadása, amely kellően dinamikus a tekintetben, hogy a mindenkori kommunikációs szituációt, a közlő és a befogadó előzetes tudását, kognitív képességeit és attitüdjeit is figyelembe vegye, valamint a diskurzusban megjelenő neologizmusokat szövegkörnyezetükben vizsgálja. Ezeknek a szempontoknak az érvényesítésével adott meg e fejezet egy olyan (munka)definíciót, amelynek értelmében a negyedik fejezetben elemzett alakulatok neologizmusnak tekinthetők.

A harmadik fejezet három nagy témát, három jelentésszervező elvet, a metonimikus, a metaforikus jelentésviszonyokat, továbbá a fogalmi integráció elméletét mutatta be abból a szempontból, hogy milyen szerepet tölthetnek be a neologizmusok létrejöttében, és jelenlétük mely tekintetben segítheti a szemantikai elemzést. Valamennyi jelenség bemutatásában röviden utalt a magyar és nemzetközi szakirodalomnak azokra a megállapításaira, amelyek a vizsgált téma szempontjából relevánsak.

A negyedik fejezetben tizennégy neologizmus szemantikai szerkezetének elemzésére került sor. Bár ezek a szavak mind grammatikai felépítésüket, mind keletkezésük körülményeit tekintve jelentős mértékben különböznek egymástól, az elemzések során közös keretben, a korábban bemutatott fogalmi integrációs modellben elemeztem őket, rámutatva a szemantikai felépítésükben gyakran és igen változatos módon megjelenő metaforikus és metonimikus jelentésviszonyokra is. A választott elméleti keret nyújtotta 
lehetőségeknek, így például a grafikus ábrázolásnak köszönhetően eredményesen bemutathatóvá váltak azok a mentális és kognitív folyamatok, amelyek a neologizmusok megjelenésekor feltételezhetően részt vesznek a jelentés szervezésében, a jelentéskonstruálás folyamatában. Ezek a folyamatok ugyan közvetlenül nem tanulmányozhatók, de vannak olyan lehetőségek, amelyek segítségével megkísérelhető modellálásuk.

Az egyik ilyen lehetőség időről időre olyan kérdőíves felmérések elvégzése, amelyekben a több korcsoportba tartozó adatközlők a neologizmusok (fel)ismertségéröl, jelentéséről, illetve e neologizmusokhoz kapcsolódó attitüdjükről nyilatkoznak. Ilyen kérdőíves vizsgálódásokat 2006 óta végeztem évente egy vagy két alkalommal, és a jelen munkában a 2008 és 2011 között keletkezett vonatkozó eredményeket minden elemzés esetében közöltem is.

A feltételezett mentális és kognitív folyamatok modellálásához további segítséget nyújtott a fogalmi integrációs elmélet és az elmélet adta grafikus ábrázolási lehetőség az elemzéseknek és ezeknek az ábráknak az elkészítésekor minden esetben a kérdőíves felmérésben kapott adatokra, tehát az adatközlők körülírásaira, szinonimajavaslataira, feltételezhető értelmezési vagy félreértési stratégiáira támaszkodtam, így kerülve el az ábrázolt folyamatok esetleges szubjektivitását. Az elemzések során a választott keretben olyan neologizmusok szemantikai szerkezetének bemutatására is vállalkoztam, amelyek a kérdőíves felmérések tanulsága szerint „kevésbé vagy nehezebben értelmezhetőek”, néhány adatközlő válasza alapján egyenesen „rosszul sikerültek” voltak: az elemzések a szemantikai szerkezet feltárásával ezekben az esetekben is igyekeztek bemutatni azokat a folyamatokat, amelyek miatt a neologizmus jelentésének megértése akadályokba ütközhet.

Az elméleti áttekintés és az elemzések több alkalommal is rámutattak, hogy a neologizmusok olyan dinamikus, a mindenkori közlö-befogadó viszonyában változó mértékben újszerü jelenségek, amelyek létrejöttében és értelmezésében is változatos mentális és kognitív nyelvhasználói stratégiák érvényesülnek. Mint az magából a vizsgált jelenségből is következik, a neologizmusokkal kapcsolatos jövőbeli feladatok folyamatosan napirenden vannak. Az újonnan keletkező alakulatok gyüjtésén és több szempontú elemzésén túl érdemes a korábbi keletkezésủek életének - meggyökeresedésének vagy eltủnésének - tanulmányozását is folytatni. A jelen munka keretei között e folyamat egy pillanatnyi metszetének bemutatására volt lehetőség; a további elemzés a jövő feladata. 


\section{IRODALOM}

Arisztotelész 1999. Rétorika (ford. Adamik Tamás). Budapest: Telosz Kiadó.

Arisztotelész 2004. Poétika (ford. Sarkady János). Szeged: Lazi Könyvkiadó.

Balogh Judit 2000. Az igekötő. In: Keszler Borbála (szerk.): Magyar grammatika. Budapest: Nemzeti Tankönyvkiadó. 264-267.

Barcelona, Antonio 2002. Clarifying and applying the notions of metaphor and metonymy within cognitive linguistics: an update. In: Dirven, René - Pörings, Ralf (eds): Metaphor and Metonymy in Comparison and Contrast. Berlin - New York: Mouton de Gruyter. 207-277.

Barcelona, Antonio 2003. The case for a metonymic basis of pragmatic inferencing. In: Panther, KlausUwe - Thornburg, Linda L. (eds): Metonymy and Pragmatic Inferencing. Amsterdam-Philadelphia: John Benjamins. 81-102.

Barnden, John A. 2010. Metaphor and Metonymy: Making Their Connections More Slippery. Cognitive Linguistics 21 (1). 1-34.

Bartsch, Renate 2003. Generating polysemy: metaphor and metonymy. In: Dirven, René - Pörings, Ralf (eds): Metaphor and Metonymy in Comparison and Contrast. Berlin - New York: Mouton de Gruyter. 49-74.

Bencze Lóránt 1996. A szóképek, az alakzatok és a metaforaalkotás (Trópusok és figurák). In: Szathmári István (szerk.): Hol tart ma a stilisztika? (Stíluselméleti tanulmányok). Budapest: Nemzeti Tankönyvkiadó. 234-309.

Benczes, Réka 2006. Creative Compounding in English. The Semantics of Metaphorical and Metonymical Noun-Noun Combinations. Amsterdam-Philadelphia: John Benjamins Publishing Company.

Benczes, Réka 2010. Setting limits on creativity in the production and use of metaphorical and metonymical compounds. In: Onysko, Alexander - Michel, Sascha (eds): Cognitive Perspectives on Word Formation. Berlin - New York: Mouton de Gruyter. 219-242.

Berlin, Brent - Kay, Paul 1969. Basic Color Terms. Their Universality and Evolution. Berkeley: University of California Press.

Bitskey István (szerk.) 2003. Retorikák a barokk korból. Debrecen: Kossuth Egyetemi Kiadó.

Black, Max 1962. Metaphor. In: Models and Metaphors. Studies in Language and Philosophy. New York: Cornell University Press. 25-47.

Black, Max 1980. More about metaphor. In: Ortony, Andrew (ed.): Metaphor and thought. Cambridge: Cambridge University Press. 19-43.

Black, Max 1990. A metafora (ford. Melis Ildikó). Helikon 4. 432-447.

Burkhardt, Armin 1996. Zwischen Poesie und Ökonomie: Die Metonymie als semantisches Prinzip. Zeitschrift für Germanistische Linguistik 24. 175-194. 
Cicero, Marcus Tullius 2012. De oratore - A szónokról (ford. Adamik Tamás, Csehy Zoltán, Polgár Anikó). In: Cicero összes retorikaelméleti müvei (szerk. Adamik Tamás). Pozsony: Kalligram Kiadó. 203-454.

Cornificius 2001. A C. Herenniusnak ajánlott retorika (ford. Adamik Tamás). Budapest: Magyar Könyvklub.

Coulson, Seana - Oakley, Todd 2000. Blending Basics. Cognitive Linguistics 11 (3-4). 175-196.

Coulson, Seana - Oakley, Todd 2003. Metonymy and conceptual blending. In: Panther, Klaus-Uwe Thornburg, Linda L. (eds): Metonymy and pragmatic inferencing. Amsterdam-Philadelphia: John Benjamins Publishing Company. 51-80.

Croft, William 1993. The Role of Domains in the Interpretation of Metaphors And Metonymies. Cognitive Linguistics 4 (4). 335-370.

Croft, William 2000. Explaining Language Change. An Evolutionary Approach. Harlow - New York: Longman.

Cuddon, John Anthony 1977. A Dictionary of Literary Terms. London: Andre Deutsch.

Dirven, René 2002. Structuring of word meaning III: Figurative use of language. In: Cruse, D. Alan (ed.): Handbücher zur Sprach- und Kommunikationswissenschaft. 1. Halbband. Lexikologie: ein internationales Handbuch zur Natur und Struktur von Wörtern und Wortschätzen. Berlin: De Gruyter. 337-342.

Dirven, René 2003. Metonymy and metaphor: different mental strategies of conceptualisation. In: Dirven, René - Pörings, Ralf (eds): Metaphor and Metonymy in Comparison and Contrast. Berlin - New York: Mouton de Gruyter. 75-111.

DS $=$ Wales, Katie 1990. A dictionary of stylistics. London - New York: Longman.

DTL = Van Gorp, Hendrik et al. (eds) 2001. Dictionnaire des Termes Littéraires. Párizs: Honoré Champion Éditeur.

Eggs, Ekkehard 2001. Metonymie. In: Ueding, Gert (Hrsg.): Historisches Wörterbuch der Rhetorik. Tübingen: Max Niemeyer Verlag. 1196-1223.

É. Kiss Katalin - Kiefer Ferenc - Siptár Péter 1998. Új magyar nyelvtan. Budapest: Osiris Kiadó. ÉKsz. ${ }^{2}=$ Pusztai Ferenc (főszerk.) 2003. Magyar értelmező kéziszótár. Budapest: Akadémiai Kiadó. Fábián Pál 1984. Nyelvmüvelésünk évszázadai. Budapest: Gondolat.

Fauconnier, Gilles 2007. Mental Spaces. In: Geeraerts, Dirk - Cuyckens, Herbert (eds): The Oxford Handbook of Cognitive Linguistics. Oxford: Oxford University Press. 351-376.

Fauconnier, Gilles 1994 [1985]. Mental Spaces. Cambridge: MIT Press - Cambridge University Press.

Fauconnier, Gilles - Turner, Mark 1998a. Principles of Conceptual Integration. In: Koenig, Jean-Pierre (ed.): Discourse and Cognition. Stanford, California: CSLI Publications. 269-283.

Fauconnier, Gilles - Turner, Mark 1998b. Conceptual Integration Networks. Cognitive Science 22 (2). 133-187.

Fauconnier, Gilles - Turner, Mark 1998c. Blending as a central process of grammar. http://markturner. org/centralprocess.WWW/centralprocess.html

Fauconnier, Gilles - Turner, Mark 1998d. Metaphor, metonymy, and binding. http://markturner.org/ metmet.html

Fauconnier, Gilles - Turner, Mark 2002. The Way We Think. New York: Basic Books. 
Fauconnier, Gilles - Turner, Mark 2008. Rethinking metaphor. In: Gibbs, Raymond W., Jr. (ed.): The Cambridge Handbook of Metaphor and Thought. New York: Cambridge University Press. 53-66.

Fillmore, Charles J. 1985. Frames and the semantics of understanding. Quaderni di semantica 6 (2). 222-254.

Fillmore, Charles J. 2006 [1982]. Frame Semantics. In: Geeraerts, Dirk (ed.): Cognitive Linguistics: Basic Readings. Berlin - New York: Mouton de Gruyter. 373-400.

Geeraerts, Dirk 1997. Diachronic Prototype Semantics. A Contribution to Historical Lexicology. Oxford: Clarendon Press.

Geeraerts, Dirk 2002. Conceptual Approaches III: Prototype Theory. In: Cruse, D. Alan (ed.): Handbücher zur Sprach- und Kommunikationswissenschaft. 1. Halbband. Lexikologie: ein internationales Handbuch zur Natur und Struktur von Wörtern und Wortschätzen. Berlin: De Gruyter. 284-291.

Geeraerts, Dirk 2006. Introduction. A rough guide to Cognitive Linguistics. In: Geeraerts, Dirk Dirven, René - Taylor, John R. (eds): Cognitive Linguistics: Basic Readings (Cognitive Linguistics Research 34). Berlin - New York: Mouton de Gruyter. 1-28.

Geeraerts, Dirk - Cuyckens, Hubert 2007. Introducing Cognitive Linguistics. In: Geeraerts, Dirk Cuyckens, Hubert (eds): The Oxford Handbook of Cognitive Linguistics. Oxford - New York: Oxford University Press. 3-21.

Gibbs, Raymond W. 1993. Process and products in making sense of tropes. In: Ortony, Andrew (ed.): Metaphor and Thought (Second Edition). Cambridge - New York: Cambridge University Press. 252-276.

Gibbs, Raymond W., Jr. 2000. Making good psychology out of blending theory. Cognitive Linguistics $11(3 / 4) .347-358$.

Glucksberg, Sam 2008. How Metaphors Create Categories - Quickly. In: Gibbs, Raymond W., Jr. (ed.): The Cambridge Handbook of Metaphor and Thought. New York: Cambridge University Press. 67-83.

Glucksberg, Sam - Keysar, Boaz 1993. How metaphors work. In: Ortony, Andrew (ed.): Metaphor and Thought (Second Edition). Cambridge - New York: Cambridge University Press. 401-424.

Goossens, Louis 2003 [1990]. Metaphtonymy: The interaction of metaphor and metonymy in expressions for linguistic action. In: Dirven, René - Pörings, Ralf (eds): Metaphor and Metonymy in Comparison and Contrast. Berlin - New York: Mouton de Gruyter. 349-377.

Grady, Joseph E. 1997. Theories are Buildings revisited. Cognitive Linguistics 8 (4). 267-290.

Grady, Joe 1998. The "Conduit Metaphor" Revisited: A Reassessment of Metaphors for Communication. In: Koenig, Jean-Pierre (ed.): Discourse and Cognition. Stanford, California: CSLI Publications. 205-218.

Grady, Joseph 2000. Cognitive mechanisms of conceptual integration. Cognitive Linguistics 11 (3/4). 335-345.

Grady, Joseph - Johnson, Christopher 2003. Converging evidence for the notions of subscene and primary scene. In: Dirven, René - Pörings, Ralf(eds): Metaphor and Metonymy in Comparison and Contrast. Berlin - New York: Mouton de Gruyter. 533-554.

Grady, Joseph E. - Oakley, Todd - Coulson, Seana 1999. Blending and metaphor. In: Steen, Gerard Gibbs, Raymond (eds): Metaphor in cognitive linguistics. Philadelphia: John Benjamins. 101-125. Gumperz, John J. 1982. Discourse strategies. Cambridge: Cambridge University Press. 
Haiman, John 1991. From V/2 to subject clitics: evidence from Northern Italian. In: Traugott, Elizabeth Closs - Heine, Bernd (eds): Approaches to Grammaticalization, vol. II. Amsterdam: John Benjamins. 135-158.

Hámori Ágnes 2009. A figyelem és a beszédaktusok összefüggései a társalgásban. Doktori disszertáció (kézirat).

Hámori Ágnes 2012. „Tudunk mi normális hangnemben is társalogni!” Stílus, személyesség és egyezkedés az internetes fórumokon folyó társalgásban. In: Tátrai Szilárd - Tolcsvai Nagy Gábor (szerk.): A stílus szociokulturális tényezöi. Kognitív stilisztikai tanulmányok. Budapest: Eötvös Loránd Tudományegyetem. 223-261.

Heltainé Nagy Erzsébet 2008. Archaizmus. In: Szathmári István (föszerk.): Alakzatlexikon. A retorikai és stilisztikai alakzatok kézikönyve. Budapest: Tinta Könyvkiadó. 127-132.

Imre Mihály (szerk.) 2000. Retorikák a reformáció korából. Debrecen: Csokonai Könyvtár.

ISZ = Tolcsvai Nagy Gábor 2007. Idegen szavak szótára. Budapest: Osiris Kiadó.

Jakobson, Roman 2003 [1956]. The metaphoric and metonymic poles. In: Dirven, René - Pörings, Ralf (eds): Metaphor and Metonymy in Comparison and Contrast. Berlin - New York: Mouton de Gruyter. 41-47.

Jakobson, Roman - Halle, Morris 1956. Fundamentals of Language. The Hague: Mouton.

J. Soltész Katalin 1959. Az ösi magyar igekötők (meg, el, ki, be, fel, le). Budapest: Akadémiai Kiadó.

Kazinczy Ferenc 1960 [1819]. Ortológus és neológus nálunk és más nemzeteknél. In: Válogatott müvei II. Budapest: Szépirodalmi Könyvkiadó. 194-211.

Keller, Rudi 1985. Towards a Theory of Linguistic Change. In: Ballmer, Thomas T. (ed.): Linguistic Dynamics: Discourses, Procedures and Evolution (Research in Text Theory vol. 9). Berlin - New York: Walter de Gruyter. 211-237.

Keller, Rudi 1990. Sprachwandel: von der unsichtbaren Hand in der Sprache. Tübingen: Francke.

Kiefer Ferenc (szerk.) 2000. Strukturális magyar nyelvtan 3. Morfológia. Budapest: Akadémiai Kiadó.

Kintsch, Walter - van Dijk, Teun A. 1978. Toward a model of text comprehension and production. Psychological Review 85 (5). 363-394.

Kiss Jenő 1995. Társadalom és nyelvhasználat: szociolingvisztikai alapfogalmak. Budapest: Nemzeti Tankönyvkiadó.

Kiss Jenő - Pusztai Ferenc 2003. Magyar nyelvtörténet. Budapest: Osiris Kiadó.

Kleiber, Georges 1995. Polisémie, transferts de sens et métonymie integrée. Folia Linguistica 29 (1-2). $105-132$.

Kocsány Piroska 2008a. Metafora. In: Szathmári István (főszerk.): Alakzatlexikon. A retorikai és stilisztikai alakzatok kézikönyve. Budapest: Tinta Könyvkiadó. 390-402.

Kocsány Piroska 2008b. Metonímia. In: Szathmári István (főszerk.): Alakzatlexikon. A retorikai és stilisztikai alakzatok kézikönyve. Budapest: Tinta Könyvkiadó. 410-420.

Kozocsa Sándor Géza 2008. Neologizmus. In: Szathmári István (föszerk.): Alakzatlexikon. A retorikai és stilisztikai alakzatok kézikönyve. Budapest: Tinta Könyvkiadó. 425-428.

Kövecses Zoltán 1998. A metafora a kognitív nyelvészetben. In: Pléh Csaba - Győri Miklós (szerk.): A kognitív szemlélet és a nyelv kutatása. Budapest: Pólya Kiadó. 50-82.

Kövecses Zoltán 2005a. A metafora. Budapest: Typotex Kiadó. 
Kövecses Zoltán 2005b. Túl a fogalmi metaforákon. In: Kertész András - Pelyvás Péter (szerk.): Tanulmányok a kognitív szemantika köréböl (Általános Nyelvészeti Tanulmányok XXI.). Budapest: Akadémiai Kiadó. 71-88.

Kövecses Zoltán 2006. A fogalmi metaforák elmélete és az elmélet kritikája. Világosság 47 (8-10). 87-97.

Kövecses Zoltán 2009. Versengő metaforaelméletek? Magyar Nyelv 105 (3). 271-280.

Kövecses Zoltán - Benczes Réka 2010. Kognitiv nyelvészet. Budapest: Akadémiai Kiadó.

Kövecses, Zoltán - Radden, Günther 1998. Metonymy: Developing a cognitive linguistic view. Cognitive Linguistics 9 (1). 37-77.

Kramer, Olaf 2003. Neologismus. In: Ueding, Gert (ed.): Historisches Wörterbuch der Rhetorik. Tübingen: Max Niemeyer Verlag. 210-217.

Ladányi Mária 2007. Produktivitás és analógia a szóképzésben: elvek és esetek. Budapest: Tinta Könyvkiadó.

Ladányi Mária - Tolcsvai Nagy Gábor 2008. Funkcionális nyelvészet. In: Tolcsvai Nagy Gábor Ladányi Mária (szerk.): Tanulmányok a funkcionális nyelvészet köréböl (Általános Nyelvészeti Tanulmányok XXII.). Budapest: Akadémiai Kiadó. 17-59.

Lakoff, George 1987. Women, fire and dangerous things. Chicago-London: The University of Chicago Press.

Lakoff, George 1990. The Invarience Hypothesis: is abstract reason based on image schemas? Cognitive Linguistics 1 (1). 39-74.

Lakoff, George 2006 [1993]. The contemporary theory of metaphor. In: Geeraerts, Dirk (ed.): Cognitive Linguistics: Basic Readings. Berlin - New York: Mouton de Gruyter. 185-238.

Lakoff, George 2008. The neural theory of metaphor. In: Gibbs, Raymond W., Jr. (ed.): The Cambridge Handbook of Metaphor and Thought. New York: Cambridge University Press. 17-38.

Lakoff, George - Johnson, Mark 1980. Metaphors we live by. Chicago-London: The University of Chicago Press.

Langacker, Ronald W. 1987. Foundations of cognitive grammar. Vol. I. Theoretical Prerequisites. Stanford, California: Stanford University Press.

Langacker, Ronald W. 1993. Reference-point constructions. Cognitive Linguistics 4 (1). 1-38.

Langacker, Ronald W. 1999. Assessing the cognitive linguistic enterprise. In: Janssen, Theo - Redeker, Gisela (eds): Cognitive linguistics: Foundations, scope, and methodology. Berlin - New York: Mouton de Gruyter. 13-60.

Langacker, Ronald W. 2000. A Dynamic Usage-Based Model. In: Barlow, Michael - Kemmer, Suzanne (eds): Usage-Based Models of Language. Stanford, California: CSLI Publications. 1-63.

Langacker, Ronald W. 2001. Discourse in Cognitive Grammar. Cognitive Linguistics 12 (2). 143-188.

Langacker, Ronald W. 2008. Cognitive grammar. A basic introduction. Oxford - New York: Oxford University Press.

Lehrer, Adrienne 1998. Spaces, holics, and thons: the semantics of English combining forms. American Speech 73 (1). 3-28.

Lehrer, Adrienne 2003. Understanding trendy neologisms. Rivista di Linguistica 15 (2). 369-382.

Lehrer, Adrienne 2007. Blendalicious. In: Munat, Judith (ed.): Lexical Creativity, Texts and Context. Amsterdam-Philadelphia: John Benjamins. 115-133. 
Lengyel Klára 2000. A ritkább szóalkotási módok. In: Keszler Borbála (szerk.): Magyar grammatika. Budapest: Nemzeti Tankönyvkiadó. 337-345.

Magyar Tudományos Akadémia 2000. A magyar helyesírás szabályai. Budapest: Akadémiai Kiadó.

Minya Károly 2003. Mai magyar nyelvújitás - szókészletünk módosulása a neologizmusok tükrében a rendszerváltozástól az ezredfordulóig. Budapest: Tinta Könyvkiadó.

Minya Károly 2007. Új szavak. Budapest: Tinta Könyvkiadó.

NMNsz = Halász Előd - Földes Csaba - Uzonyi Pál 1998. Német-magyar nagyszótár: új német helyesirással. Budapest: Akadémiai Kiadó.

Norrick, Neal R. 1981. Semiotic principles in semantic theory. Amsterdam: John Benjamins.

Oakley, Todd V. 1998. Conceptual blending, narrative discourse, and rhetoric. Cognitive Linguistics 9 (4). 321-360.

OH. = Laczkó Krisztina - Mártonfi Attila 2006. Helyesírás. Budapest: Osiris Kiadó.

Oxford = Hornby, Albert Sidney 2005. Oxford Advanced Learner's Dictionary of Current English (7th Edition). Oxford: Oxford University Press.

Panther, Klaus-Uwe - Thornburg, Linda L. 2003. On the nature of conceptual metonymy. In: Panther, Klaus-Uwe - Thornburg, Linda L. (eds): Metonymy and Pragmatic Inferencing. AmsterdamPhiladelphia: John Benjamins Publishing Company. 1-20.

Panther, Klaus-Uwe - Thornburg, Linda L. 2004. The Role of Conceptual Metonymy in Meaning Construction. In: www.metaphorik.de 06, 91-116. http://www.metaphorik.de/sites/www.metaphorik.de/files/journal-pdf/06_2004_pantherthornburg.pdf.

Panther, Klaus-Uwe - Thornburg, Linda L. 2006. Metonymy and the Way We Speak. In: Benczes, Réka - Csábi, Szilvia (eds): The Metaphors of Sixty. Papers Presented on the Occasion of the 60th Birthday of Zoltán Kövecses. Budapest: Department of American Studies, School of English and American Studies, Eötvös Loránd University. 183-195.

Panther, Klaus-Uwe - Thornburg, Linda L. 2007. Metonymy. In: Geeraerts, Dirk - Cuyckens, Herbert (eds): The Oxford Handbook of Cognitive Linguistics. Oxford: Oxford University Press. 236-263. Papafragou, Anna 1995. Metonymy and relevance. In: UCL Working Papers in Linguistics 7. 141-175. http://papafragou.psych.udel.edu/papers/mtnucl.pdf

Papafragou, Anna 1996. On Metonymy. Lingua 99. 169-195.

Papp Ferenc (szerk.) 1994. A magyar nyelv szóvégmutató szótára. Budapest: Akadémiai Kiadó.

Pátrovics Péter 2002. Néhány gondolat a magyar igekötők eredetéről, valamint aspektus- és akcióminőség-jelölő funkciójuk (ki)alakulásáról. Magyar Nyelvőr 126 (4). 481-489.

Pethő József 2009. Szintaktikai és szemantikai szerkezetek a reklámszlogenekben. In: Keszler Borbála - Tátrai Szilárd (szerk.): Diskurzus a grammatikában - grammatika a diskurzusban (Segédkönyvek a nyelvészet tanulmányozásához 88.). Budapest: Tinta Könyvkiadó. 219-225.

Quintilianus, Marcus Fabius 2008. Szónoklattan (ford. Adamik Tamás). Pozsony: Kalligram Kiadó.

Radden, Günter 2003. How metonymic are metaphors? In: Dirven, René - Pörings, Ralf (eds): Metaphor and Metonymy in Comparison and Contrast. Berlin - New York: Mouton de Gruyter. 407434.

Radden, Günter - Kövecses, Zoltán 1999. Towards a theory of metonymy. In: Panther, Klaus-Uwe Radden, Günter (eds): Metonymy in Language and Thought. Amsterdam-Philadelphia: John Benjamins Publishing Company. 17-59.

Révai Miklós 1973 [1805]. A magyar szép toll. Budapest: Akadémiai Kiadó - Zrínyi Kiadó. 
Richards, Ivor Armstrong 1950 [1936]. The Philosophy of Rhetoric. New York: Oxford University Press.

Ricoeur, Paul 2006 [1975]. Az élő metafora (ford. Földes Györgyi). Budapest: Osiris Kiadó.

Riemer, Nick 2001. Remetonymizing metaphor. Cognitive Linguistics 12 (4). 379-401.

Riemer, Nick 2003. When is a metonymy no longer a metonymy? In: Dirven, René - Pörings, Ralf (eds): Metaphor and Metonymy in Comparison and Contrast. Berlin - New York: Mouton de Gruyter. 379-406.

Rosch, Eleanor 1977. Human Categorization. In: Warren, Neil (ed.): Studies in Cross-Cultural Psychology. Vol. I. London: Academic Press. 1-49.

Rosch, Eleanor 1978. Principles of Categorization. In: Rosch, Eleanor - Lloyd, B. B. (eds): Cognition and Categorization. Hillsdale: Lawrence Erlbaum. 27-48.

Ruiz de Mendoza, Francisco J. 1996. Understanding through metonymy: the role of metonymy in communication and cognition. In: Penas, Beatriz (ed.): The Pragmatics of Understanding and Misunderstanding. Zaragoza: University of Zaragoza. 197-208.

Ruiz de Mendoza, Francisco J. 1998. On the nature of blending as a cognitive phenomenon. Journal of Pragmatics 30 (3). 259-274.

Ruiz de Mendoza, Francisco J. - Díez, Olga I. 2002. Patterns of conceptual interaction. In: Dirven, René - Pörings, Ralf (eds): Metaphor and Metonymy in Comparison and Contrast. Berlin - New York: Mouton de Gruyter. 489-352.

Ruiz de Mendoza Ibáñez, Francisco José - Hernández, Lorena Pérez 2001. Metonymy and the grammar: motivation, constraints and interaction. Language \& Communication 21 (4). 321-357.

Ruiz de Mendoza, Francisco José - Peña, M. Sandra 2005. Conceptual interaction, cognitive operations and projection spaces. In: Francisco J. Ruiz de Mendoza and M. Sandra Peña (eds): Cognitive linguistics: internal dynamics and interdisciplinary interaction. Berlin - New York: Mouton de Gruyter. 249-280.

Sándor Klára - Langman, Juliet - Pléh Csaba 1998. Egy magyarországi „ügynökvizsgálat” tanulságai. Valóság 8. 29-40.

Schweikle, Irmgard - Schweikle, Günther (Hrsg.) 1984. Metzler Literatur Lexikon. Stuttgart: Metzler. Scott, A. F. 1965. Current Literary Terms. London-Melbourne-Toronto: Macmillan.

Shipley, Joseph T. 1970. Dictionary of world literary terms. London: George Allen \& Unwin Ltd.

Sólyom Réka 2009a. Napjaink neologizmusainak mondatbeli értelmezése. In: Keszler Borbála - Tátrai Szilárd (szerk.): Diskurzus a grammatikában - grammatika a diskurzusban. Budapest: Tinta Könyvkiadó. 257-265.

Sólyom Réka 2009b. Megértési stratégiák és attitüdök neologizmusok értelmezésében. In: Váradi Tamás (szerk.): III. Alkalmazott Nyelvészeti Doktorandusz Konferencia kötete. Budapest: MTA Nyelvtudományi Intézet. 152-166.

Sólyom Réka 2009c. Újabb neologizmusaink szemantikai vizsgálata. In: Nádor Orsolya (szerk.): A magyar mint európai és mint világnyelv. A XVIII. Magyar Alkalmazott Nyelvészeti Kongresszus elöadásai. Budapest: MANYE - Balassi Intézet. 259-264.

Sólyom Réka 2009d. Neologizmusok a mai magyar szókészletben. In: Kuna Ágnes - Veszelszki Ágnes (szerk.): Félúton 3. A harmadik Félúton konferencia (2007) kiadványa. Budapest: ELTE BTK Nyelvtudományi Doktori Iskola. 260-273. 
Sólyom Réka 2010a. Értelmezési stratégiák és attitüdök vizsgálata fogalmi terek ötvöződését tartalmazó köznyelvi neologizmusainkban. In: Illés-Molnár Márta - Kaló Zsuzsa - Klein Laura - Parapatics Andrea (szerk.): Félúton 5.: az ELTE BTK Nyelvtudományi Doktori Iskolájának konferenciája: 2009. április 22-23. Budapest: L'Harmattan - ELTE BTK Nyelvtudományi Doktori Iskola. 139-154.

Sólyom Réka 2010b. Neologizmusok kognitív szemantikai megközelítése. Magyar Nyelvőr 134 (3). 270-282.

Sólyom Réka 2011. Celeb, bevállal, H1N1 - neologizmusok megítélése, értékelése különbözö korcsoportok körében. In: Hires-László Kornélia - Karmacsi Zoltán - Márku Anita (szerk.): Nyelvi mitoszok, ideológiák, nyelvpolitika és nyelvi emberi jogok Közép-Európában elméletben és gyakorlatban. A 16. Élönyelvi Konferencia elöadásai. Budapest: Tinta Könyvkiadó - Beregszász: II. Rákóczi Ferenc Kárpátaljai Magyar Főiskola Hodinka Antal Intézete. 335-344.

Sólyom Réka 2012a. Becéloz, betámad, bevállal - be igekötős neologizmusaink szemantikájáról. In: Parapatics Andrea (föszerk.): Doktoranduszok a nyelvtudomány útjain: A hatodik Félúton konferencia, ELTE BTK, 2010. október 7-8. Budapest: ELTE Eötvös Kiadó. 203-213.

Sólyom Réka 2012b. E- előtagú neologizmusaink szemantikájáról. In: Váradi Tamás (szerk.): VI. Alkalmazott Nyelvészeti Doktoranduszkonferencia kötete. Budapest: MTA Nyelvtudományi Intézet. $156-165$.

Sólyom Réka 2012c. Fórumszövegek vizsgálata: neologizmusok elemzése a szemantikai felépítés és a stílus szociokulturális rétegzettségének vonatkozásában. In: Tátrai Szilárd - Tolcsvai Nagy Gábor (szerk.): A stílus szociokulturális tényezöi. Kognitív stilisztikai tanulmányok. Budapest: Eötvös Loránd Tudományegyetem. 263-299.

Sólyom, Réka 2013. A study of forum texts: semantic and stylistic analyses. Studia Linguistica Hungarica 28. 149-165.

Stirling, Lesley 1996. Metonymy and anaphora. Belgian Journal of Linguistics 10. 69-88.

Swb = Wilpert, Gero von 1989. Sachwörterbuch der Literatur. Stuttgart: Alfred Kröner Verlag.

Sweetser, Eve 1988. Grammaticalization and semantic bleaching. In: Axmaker, Shelley -Jaisser, Annie - Singmaster, Helen (eds): Berkeley Linguistics Society: General Session and Parasession on Grammaticalization. Berkeley: University of California. 389-405.

Sweetser, Eve 1990. From Etimology to Pragmatics. Cambridge: Cambridge University Press.

Sweetser, Eve 1996. Mental Spaces and the Grammar of Conditional Constructions. In: Sweetser, Eve - Fauconnier, Gilles (eds): Spaces, worlds, and grammar. Chicago: The University of Chicago Press. 318-333.

Sweetser, Eve 1999. Compositionality and blending. In: Janssen, Theo -Redeker, Gisela (eds): Cognitive Linguistics: Foundations, scope, and methodology (Cognitive Linguistics Research 15). Berlin: Mouton de Gruyter. 129-162.

Sweetser, Eve 2000. Blended spaces and performativity. Cognitive Linguistics 11 (3-4). 305-334.

Sweetser, Eve - Fauconnier, Gilles 1996. Cognitive Links and Domains: Basic Aspects of Mental Space Theory. In: Sweetser, Eve - Fauconnier, Gilles (eds): Spaces, worlds, and grammar. Chicago: The University of Chicago Press. 1-28.

Szathmári István 2004. Stilisztikai lexikon: stilisztikai fogalmak magyarázata szépirodalmi példákkal szemléltetve. Budapest: Tinta Könyvkiadó.

Szathmári István (föszerk.) 2008. Alakzatlexikon: a retorikai és stilisztikai alakzatok kézikönyve. Budapest: Tinta Könyvkiadó.

Szili Katalin 2005. A be igekötő jelentésváltozásai I. Magyar Nyelvőr 129: 151-164. 
Tátrai Szilárd 2004. A kontextus fogalmáról. Magyar Nyelvőr 128 (4). 479-494.

Tátrai Szilárd 2011. Bevezetés a pragmatikába. Funkcionális kognitív megközelités. Budapest: Tinta Könyvkiadó.

Taylor, John R. 2002. Conceptual approaches V. Concepts and domains. In: Cruse, D. Alan (ed.): Handbücher zur Sprach- und Kommunikationswissenschaft. 1. Halbband. Lexikologie: ein internationales Handbuch zur Natur und Struktur von Wörtern und Wortschätzen. Berlin: De Gruyter. 296-303.

Terestyéni Ferenc 1955. A neologizmusok kérdéséhez. Magyar Nyelv 51 (3-4). 297-302., 463-468.

Terestyéni Ferenc 1958. A neologizmusok. In: Fábián Pál - Szathmári István - Terestyéni Ferenc. A magyar stilisztika vázlata. Budapest: Tankönyvkiadó Vállalat. 48-52.

Tolcsvai Nagy Gábor 1996. A nyelvi modell. In: uő: A magyar nyelv stilisztikája. Budapest: Nemzeti Tankönyvkiadó. 32-46.

Tolcsvai Nagy Gábor 2000. A kognitív nyelvészet elméleti hozadéka a szövegtan számára. Magyar Nyelvör 124: 494-500.

Tolcsvai Nagy Gábor 2001a. A magyar nyelv szövegtana. Budapest: Nemzeti Tankönyvkiadó.

Tolcsvai Nagy, Gábor 2001b. Conceptual Metaphors and Blends of "Understanding" and "Knowledge" in Hungarian. Acta Linguistica Hungarica 48 (1-3). 79-100.

Tolcsvai Nagy, Gábor 2005a. A Cognitive Theory of Style. Frankfurt am Main: Peter Lang.

Tolcsvai Nagy Gábor 2005b. A nyelvi kategorizáció kognitív nyelvészeti keretben. Acta Academiae Paedagogicae Agriensis Sectio Linguistica Hungarica 32. 5-20.

Tolcsvai Nagy Gábor 2005c. Kognitív jelentéstani vázlat az igekötős igéről. Magyar Nyelv 101 (1). $27-43$.

Tolcsvai Nagy Gábor 2010. Kognitív szemantika. Nyitra: Europica varietas.

Tolcsvai Nagy Gábor 2012. A stílus szociokulturális tényezőinek kognitív nyelvészeti megalapozása.

In: Tátrai Szilárd - Tolcsvai Nagy Gábor (szerk.): A stílus szociokulturális tényezöi. Kognitív stilisztikai tanulmányok. Budapest: Eötvös Loránd Tudományegyetem. 19-49.

Tolcsvai Nagy Gábor 2013. Bevezetés a kognitiv nyelvészetbe. Budapest: Osiris Kiadó.

Traugott, Elisabeth Closs - Dasher, Richard B. 2004. Regularity in Semantic Change. Cambridge: Cambridge University Press.

Turner, Mark 1987. Death is the Mother of Beauty: Mind, metaphor, criticism. Chicago: University of Chicago Press.

Turner, Mark 2007. Conceptual Integration. In: Geeraerts, Dirk - Cuyckens, Herbert (eds): The Oxford Handbook of Cognitive Linguistics. Oxford: Oxford University Press. 377-393.

Ueding, Gert (Hrsg.) 2001. Historisches Wörterbuch der Rhetorik. Tübingen: Max Niemeyer Verlag. Van Dijk, Teun A. 1982. Kontextus és megismerés. Tudáskeretek és beszédaktus-megértés. In: Penavin Olga - Thomka Beáta (szerk.): Szövegelmélet. Tanulmányok, 15. füzet. Újvidék: A Magyar Nyelv, Irodalom és Hungarológiai Kutatások Intézete.

Váradi Tamás 2002. The Hungarian National Corpus. In: Proceedings of the 3rd LREC Conference. Spanyolország: Las Palmas. 385-389. http://corpus.nytud.hu/mnsz

Verseghy Ferenc 1998 [1793]. Bevezetés a magyar nyelv törvényeibe, amely Adelung rendszere, nemkülönben a keleti nyelvek szelleme, valamint a tiszai és az erdélyi nyelvjárás alapján készült (ford. Hegyi Balázs). Szolnok: Verseghy Ferenc Megyei Könyvtár.

Zsemlyei János 1996. A mai magyar nyelv szókészlete és szótárai. Kolozsvár: Erdélyi Tankönyvtanács. 



\section{A NYELVTUDOMÁNYI ÉRTEKEZÉSEK EDDIG MEGJELENT SZÁMAI}

1. BENKÖ LORÁND: A magyar ly hang története. 1953.

2. HAJdú PÉTER: A magyarság kialakulásának előzményei. 1953.

3. Deme LÁszló: A magyar nyelvjárások néhány kérdése. 1953.

4. Helyesírásunk időszerü kérdései. Szerkesztette BENKö LoRÁnd. 1955.

5. A magyar östörténet kérdései. A Magyar Nyelvtudományi Társaság vitaülése 1953. december 1. 1955.

6. Pais Dezsö, BÁrczi Géza, BenKö Loránd: A magyar ly hang kérdéséhez. 1955.

7. HoRvÁth JÁNOS: Vitás verstani kérdések. 1955.

8. LAKÓ GYÖRGY: Északi-manysi nyelvtanulmányok. 1956.

9. A „Helyesírásunk időszerü kérdései” vitája. Szerkesztette FÁBIÁN Pál. 1956.

10. KÁRoly SÁndor: Igenévrendszerünk a kódexirodalom első szakaszában. 1956.

11. Melich János: Dolgozatok I. 1957.

12. BÁNHIDI Zoltán: A magyar összetett igealakok jelentéstörténete. 1957.

13. BERRÁR JolÁN: Fejezetek határozóragjaink élettörténetéből. 1957.

14. Tомpa JózSEF: A névszói kötőhangzó szófaj megkülönböztető szerepe. 1957.

15. HeXENDORF EDIT: Szótanulmányok a szellemi élet középkori magyar kifejezésanyagának köréböl. 1958.

16. KÁROLY SÁNDOR: Az értelmező és az értelmezői mellékmondat a magyarban. 1958.

17. Magyar hangtani dolgozatok. Szerkesztette BENKÖ LORÁND. 1958.

18. Fónagy Iván: A hangsúlyról. 1958.

19. PAPP LÁszló: XVI. század végi nyelvjárásaink tanulmányozása. 1959.

20. Deme LÁszló: A XVI. század végi nyelvi norma kérdéséhez. 1959.

21. KirÁly Péter: Ismeretlen magyar glosszák. 1959.

22. INCZEFI GÉZA: Szeged környékének földrajzi nevei. 1960.

23. Berrár Jolán: A magyar hasonlító mondatok története a XVI. század közepéig. 1960.

24. Goмвосz Zoltán: Honfoglalás elötti bolgár-török jövevényszavaink. 1960.

25. PAPP László: Nyelvjárás és nyelvi norma XVI. századi deákjaink gyakorlatában. 1961.

26. BÜKY BÉLA: A fővárosi keresztnévadás hatóerői. 1961.

27. KÁzMÉr Mikıós: A magyar affrikátaszemlélet. 1961.

28. KarÁcsony SÁndor Zsigmond: Személyneveink 1500-tól 1800-ig. 1961.

29. Antal László: A magyar esetrendszer. 1961.

30. PAIS Dezső: Szer. 1961.

31. RADANOVICS KÁROLY: Északi-osztják nyelvtan. 1961.

32. MÁrton Gyula: A borsavölgyi nyelvjárás igetövei és igealakjai. 1962.

33. B. LőRINCZY ÉvA: Képző- és névrendszertani vizsgálódások. 1962.

34. EleKFi LÁszLó: Vizsgálatok a hanglejtés megfigyelésének módjaihoz. 1962.

35. BenKö LÁszló: A szépirodalmi stílus elemzése. 1962. 
36. A szótárírás elmélete és gyakorlata a Magyar Nyelv Értelmező Szótárában. Szerkesztette ORSZÁGH LÁSZLÓ. 1962.

37. FónAGy Iván: A metafora a fonetikai münyelvben. 1963.

38. Szótörténeti és szófejtő tanulmányok. Szerkesztette Pais Dezsỏ és Benkő Loránd. 1963.

39. RÁcz EndRE: A magyar nyelv következményes mondatai. 1963.

40. Tanulmányok a magyar nyelv életrajza köréből. LigetI LAJos és PAIs Dezsö közremüködésével szerkesztette BENKŐ LORÁND. 1963.

41. Melich JÁnos: Dolgozatok II. 1963:

42. D. Bartha Katalin: Tővégi magánhangzóink története a XVI. század közepéig. 1964.

43. ImRE SAmu: A magyar huszita helyesírás néhány kérdése. 1964.

44. PAPp LÁszló: Magyar nyelvủ levelek és okiratok formulái a XVI. században. 1964.

45. TÖRÖK GÁBOR: A Börzsöny-vidék nyelvjárástörténetének települési háttere. 1964.

46. Alak- és mondattani gyüjtelék. Szerkesztette Pais Dezsỏ és Benkö Loránd. 1965.

47. LÁKó GYÖRGY: A magyar hangállomány finnugor előzményei. 1965.

48. SzABÓ Zoltán: A kalotaszegi nyelvjárás igeképző-rendszere. 1965.

49. Magdics KlÁRA: A magyar beszédhangok akusztikai szerkezete. 1965.

50. HAdRovics LÁszLó: Jövevényszó-vizsgálatok. 1965.

51. Nemes István: A képszerüség eszközei Radnóti Miklós költészetében. 1965.

52. PeRrot, JeAn: Adalékok a meg igekötő funkciójának vizsgálatához a mai magyar nyelvben. 1966.

53. ZsILKA JÁNOS: A magyar mondatformák rendszere és az esetrendszer. (Tárgyas mondat szerkezetek.) 1966.

54. Deme LÁszló-Fábián PÁL-Bencédy József: A magyar helyesírás rendszere. 1966.

55. FARKAS VILMOS: Fonémastatisztikai problémák a nyelvjárástípus-történetben. 1966:

56. HEGEdŰs JózSEF: A magyar nyelv összehasonlításának kezdetei az egykorú európai nyelvtudomány tükrében. 1966.

57. Magay TAMÁs: Angol-magyar és magyar-angol szótárak hazánkban 1945 előtt. 1967.

58. A magyar nyelv története és rendszere. (A debreceni nemzetközi nyelvészkongresszus előadásai.) Szerkesztette Imre SAmu és Szathmári István. 1967.

59. Szabó T. Atтila: A kolozsvári becenevek a XVI-XIX. században. 1968.

60. H. MolnÁr Ilona: Módosító szók és módosító mondatrészletek a mai magyar nyelvben. 1968.

61. Fabricius-Kovács Ferenc: A konkrét $\rightarrow$ absztrakt jelentésfejlödés problematikája. 1968.

62. E. AbAfFy ErzséBet: XVI. századi nyugat-dunántúli missilisek helyesírásáról. 1969.

63. KesZler BorbÁla: A szókezdő mássalhangzó-torlódások feloldása korai jövevényszavainkban. 1969.

64. N. Dely Zsuzsa: A fiatal Jókai nyelve és stílusa. 1969.

65. A nyelvtudomány a haladásért. (Tanulmánykötet a Tanácsköztársaság 50. évfordulója alkalmából.) Szerkesztette KirÁly PÉTer. 1969.

66. MÁrton GyUla: A moldvai csángó nyelvjárás román kölcsönszavai. 1969.

67. Dolgozatok a hangtan köréből. Szerkesztette Pais Dezső és BenKö Loránd. 1969.

68. FehÉrtói Katalin: A XIV. századi magyar megkülönböztető nevek. 1969.

69. KISS JENÖ: A rábaközi Mihályi igeképzői. 1970.

70. Névtudományi előadások. II. névtudományi konferencia. Szerkesztette KÁzMÉr MiKLós és VÉGH JózSEF. 1970.

71. Kiss LAJos: Hatvanhét szómagyarázat. 1970.

72. ImRE SAMU: A felsőőri nyelvjárás. 1971.

73. Meggres KLÁra: Egy kétéves gyermek nyelvi rendszere. 1971.

74. FARKAS VILMOS: Helyesírásunk hangjelölésrendszerének története. 1971.

75. Nyelvészet és gyakorlat. (Tanulmánygyüjtemény.) Szerkesztette BENKÖ LORÁND és SzÉPE GYÖRGY. 1971. 
76. Dezső LÁszLó: A jelzős „főnévi csoport” kérdései a magyarban. 1971.

77. K. Szoboszlay Ágnes: A szemléletesség eszközei Németh László nyelvében. 1972.

78. Hutás Magdolna: Az ikes igeragozás állapota Révai Miklós korában. 1972.

79. Penavin Olga: A szerémségi magyar szigetek nyelve. 1972.

80. Gregor Ferenc: Magyar népi gombanevek. 1973.

81. Szende TAmás: Spontán beszédanyag gyakorisági mutatói. 1973.

82. SziLÁgyi Ferenc: Csokonai tájszógyüjtése. 1973.

83. Jelentéstan és stilisztika. (A magyar nyelvészek II. nemzetközi kongresszusának előadásai.) Szerkesztette Imre Samu, Szathmári István és SzÜts LÁszló. 1974.

84. Velcsov MÁRTONNÉ: Antropometrikus mértéknevek a magyar nyelvben. 1974.

85. Havas Ferenc: A magyar, a finn és az észt nyelv tipológiai összehasonlítása. 1974.

86. KeménY GÁBOR: Krúdy képalkotása. 1974.

87. HaJdú Mihály: Budapest utcaneveinek névtani vizsgálata. 1975.

88. Hadrovics LÁszló: Szavak és szólások. 1975.

89. Az etimológia elmélete és módszere. Szerkesztette BEnKő LorÁnd és K. SÁL Éva. 1976.

90. MÉszÁros IstvÁN: Iskolai jegyzetkönyv a XVI-XVII. század fordulójáról. 1976.

91. JAKAB IsTVÁN: A magyar igekötők vizsgálata. 1976:

92. Kiss LAJos: Szláv tükörszók és tükörjelentések a magyarban. 1976.

93. ORsZÁGH LÁszló: Angol eredetủ elemek a magyar szókészletben. 1977.

94. MolnÁr Ilona: A tartalmatlan hogy kötőszós összetett mondatok típusai szemantikai szempontból. 1977.

95. O. NAGY GÁBOR: A magyar frazeológiai kutatások története. 1977.

96. Korompay Klára: Középkori neveink és a Roland-ének. 1978.

97. GAÁl EdIT: A birtoklás kifejezése a mai magyar nyelvben. 1978.

98. DienEs DórA: A szerkesztettségi hiányosság és szövegösszefüggésbeli kiegészítése. 1978.

99. BANCZEROWSKI JANUSZ: A nyelvi kommunikáció és az információ néhány kérdése. 1979.

100. Tanulmányok a regionális köznyelviség köréből. Szerkesztette IMrE SAMU. 1979.

101. HusZÁR ÁGNEs: A predikatív viszony szemtaktikai kategóriái. 1979.

102. KASSAI Ilona: Időtartam és kvantitás a magyar nyelvben. 1979.

103. Kiss JeNÖ: Mihályi tájszótár (Rábaköz). 1979.

104. A magyar nyelv grammatikája. (A magyar nyelvészek III. nemzetközi kongresszusának elöadásai.) Szerkesztette Imre SAmu, Szathmári IstvÁn és SzÜts LÁszló. 1980.

105. MokÁny SÁndor: Magyar szófejtések. 1980.

106. B. Gergely Piroska: A kalotaszegi magyar családnevek rendszertani és funkcionális vizsgálata. 1981.

107. Lengyel Zsolt: Tanulmányok a nyelvelsajátítás köréből. 1981.

108. Guszkova Antonyina: A társadalmi kapcsolatteremtés eszközei a magyar nyelvben. 1981.

109. Kontra MiKLós: A nyelvek közötti kölcsönzés néhány kérdéséről, különös tekintettel „elangolosodó" orvosi nyelvünkre. 1981.

110. SinOR DÉNES: Tanulmányok. 1982.

111. FARKAS VILMOS: A magyar hangtörténet és helyesírástörténet rendszerbeli összefüggése. 1982.

112. JAKAB IstVÁN: A magyar igekötő szófajtani útja. 1982.

113. BENKÖ LoRÁnD: Kazinczy Ferenc és kora a magyar nyelvtudomány történetében. 1982.

114. BALÁzs Judit: A ragadványnevek szerepe Rábaszentandrás névrendszerében. 1982.

115. HoRváth Katalin: Transzformációs csoportok a magyarban. 1983.

116. É. Kiss KatAlin: A magyar mondatszerkezet generatív leírása. 1981.

117. BÁNRÉTI ZoLTÁN: A megengedő kötőszók szintaxisáról és szemantikájáról. 1983.

118. GÁsPÁri LÁszló: A századvégi novella lirizálódásáról. 1983.

119. Gósy MÁrIA: Hangtani és szótani vizsgálatok hároméves gyermekek nyelvében. 1984.

120. KISS JENŐ: A pingvintől a kolibriig. Egzotikus madarak magyar nevei. 1985. 
121. Olaszy GÁBor: A magyar beszéd leggyakoribb hangsorépítő elemeinek szerkezete és szintézise. A számítógépes beszédelőállítás néhány kérdése. 1985.

122. HeltainÉ NAgy ERzsébet: Nyelvi építkezés Sinka István balladáiban. 1986.

123. KLAUdY KINGA: Fordítás és aktuális tagolás. 1987.

124. VÉrtes O. ANDrÁs: Bevezetés a magyar hangstilisztikába. 1987.

125. T. Somogyi Magda: A passzív igetövek leíró vizsgálata a magyarban. 1987.

126. JuHÁsz Dezső: A magyar tájnévadás. 1988.

127. Kiss Jenö: Állandó szókapcsolatok a rábaközi Mihályiban. 1989.

128. Dezső LÁszló: A XVI-XVIII. századi kárpátukrán nyelvemlékek magyar jövevényszavai. 1989.

129. BENKŐ LÁsZló: Zolnai Béla élete és munkássága (1890-1969). 1990.

130. BÁRCZI GÉZA: A magyar igeragozás története. 1990.

131. Somogyi Béla: A magyar kártyanyelv szókincse. 1990.

132. DÁNIEL ÁGNES: Szö-szöveg - szer-szervez. A szöveg szerveződésének vizsgálata. 1990.

133. HoRvÁth LÁszló: Három vázlatos szinkrón metszet határozói igeneveink történetéből. 1991.

134. RÁCZ ENDRE: A belehallás jelenségéröl. 1992.

135. VARGA LÁszLó: A magyar beszéddallamok fonológiai és szintaktikai vonatkozásai. 1993.

136. Fejes Katalin: A szintaktikai állomány természete gyermekszövegekben. 1993.

137. BALÁzs GÉzA: Kapcsolatra utaló (fatikus) elemek a magyar nyelvben. 1993.

138. Hadrovics LÁszLó: A magyar Huszita Biblia német és cseh rokonsága. 1994.

139. Kiss LaJos: Földrajzi neveink nyelvi fejlődése. 1995.

140. SzATHMÁri IstvÁN: Három fejezet a magyar költői stílus történetéből. 1995.

141. Keszler Borbála: A magyar írásjelhasználat története a XVII. század közepéig. 1995.

142. NÉMETH T. ENıKÖ: A szóbeli diskurzusok megnyilatkozáspéldányokra tagolása. 1996.

143. NAGY L. JÁNOS: Ismétlések és értelmezések Weöres Sándor verseiben. 1996.

144. Tolcsvai Nagy Gábor: A nyelvi norma. 1998.

145. Gerstner Károly: A német vonatkozású elemek újabb etimológiai szótáráinkban. 1998.

146. LENGYEL KLÁrA: Az igenevek helye a szófaji rendszerben. 2000.

147. FeHÉR ERzsÉBET: A szövegkutatás megalapozása a magyar nyelvészetben. Tudománytörténeti vázlat. 2000.

148. A. Molnár Ferenc: Két régi magyar ima az oltáriszentségről. A Laskai Sorok és párhuzamos szövege a Thewrewk-kódexben. 2000.

149. WaCha BALÁzs: Időbeliség és aspektualitás a magyarban. 2001.

150. KerTÉSz ANDRÁs: Nyelvészet és tudományelmélet. 2001.

151. KocsánY Piroska: Szöveg, szövegtípus, jelentés: A mondás mint szövegtípus. 2002.

152. Kugler Nóra: A módosítószók funkciói. 2003.

153. ZsILINSZKY ÉVA: Az angol vonatkozású elemek újabb etimológiai szótárainkban. 2003.

154. Ретнö JózseF: A halmozás alakzata. 2004.

155. Olaszy GÁBor: Hangidőtartamok és időszerkezeti elemek a magyar beszédben. 2006.

156. ZeLliger ERzséBet: Az első magyar nyelvü népének és művelődéstörténeti háttere.

A Zsigmond kori Húsvéti népének keletkezésének körülményei, nyelvi kérdései. 2006.

157. D. Mátai Mária: A magyar szófajtörténet általános kérdései. 2007.

158. Dér Csilla: Grammatikalizáció. 2008.

159. FARKAS TAMÁs: Családnév-változtatás Magyarországon. 2009.

160. Bene AnNAmÁria: Medialitás jelenségek a magyar nyelvben. 2011.

161. KÁDÁr EDIT: A kopula és a nominális mondatok a magyarban. 2011.

162. Bodó CsAnÁD: A látszólagos idő valósága. 2012.

163. TAmm AnNE: Kategóriafüggetlen eset. A morfológiai eset pragmatikája a Ønnségi igerendszerben. 2013.

164. Imrényi András: A magyar mondat viszonyhálózati modellje 